Mirella Borba Santos Ferreira Costa

\title{
Wave and tidally induced processes on Rocas Atoll: geomorphological implications and future projections
}

Thesis presented to the Oceanographic Institute of the University of São Paulo, in partial fulfilment for the degree of Doctor of Science in Oceanography, with emphasis in Geological Oceanography.

Advisor: Prof. Dr. Eduardo Siegle 
University of São Paulo

Oceanographic Institute

\title{
Wave and tidally induced processes on Rocas Atoll: geomorphological implications and future projections
}

\author{
Mirella Borba Santos Ferreira Costa
}

Thesis presented to the Oceanographic Institute of the University of São Paulo, in partial fulfilment for the degree of Doctor of Science in Oceanography, with emphasis in Geological Oceanography.

Julgada em _ $/ \ldots /$

Prof. Dr.

Prof. Dr.

Prof. Dr.

Prof. Dr.

Prof. Dr. 
"Rocas está com a sua evolução quasi terminada. Poucos anos faltarão para se completar, para se tornar uma ilha na verdadeira acepção da palavra.

Como precursores, prevemos a sua futura denominação: "Ilha de Rocas", augurando também, quem sabe ? a sua habitabilidade ? um posto de pesca ? uma base aérea militar ou comercial ? uma estação meteorológica?

Tudo é possível e um futuro próximo nos dirá."

Capitão Tenente Osmar A. de A. Rodrigues Revista Marítima Brasileira, 1940 


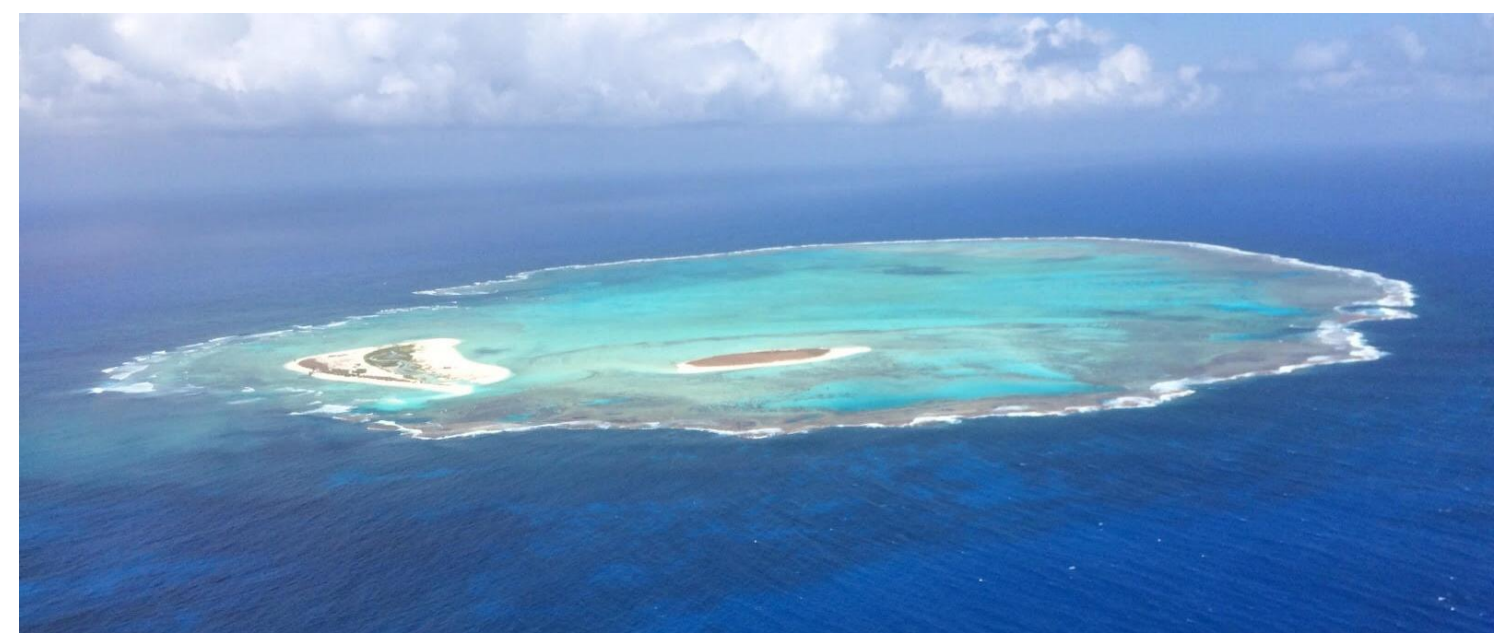

*Acervo fotográfico da Reserva Biológica do Atol das Rocas (Outubro de 2015) 


\section{Contents}

Acknowledgements................................................................................................

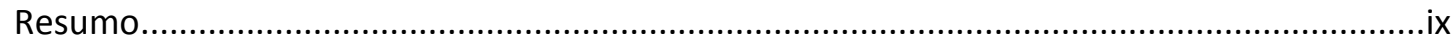

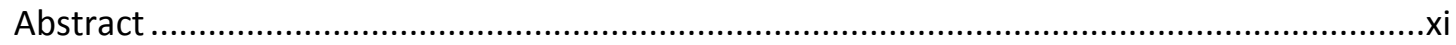

Publications produced during the PhD Candidature.................................................................iii

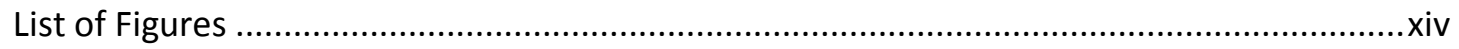

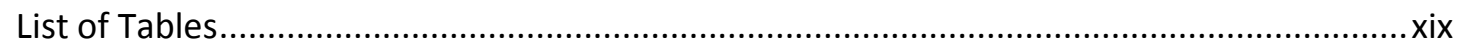

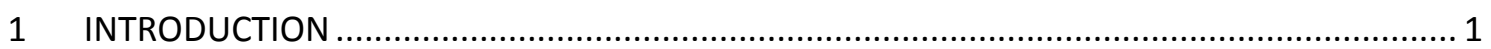

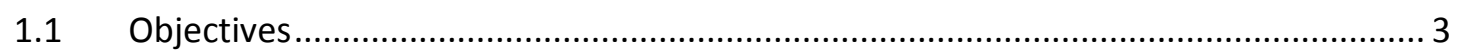

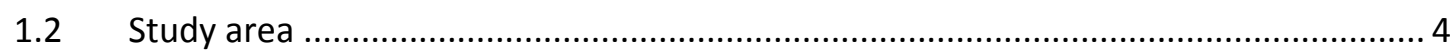

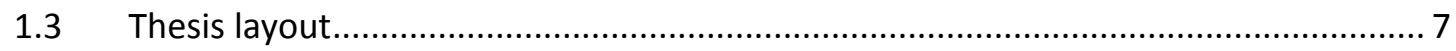

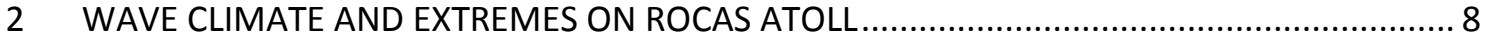

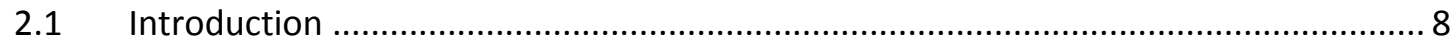

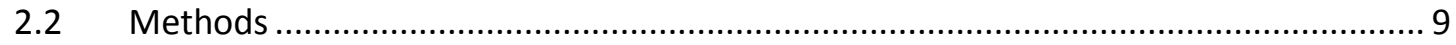

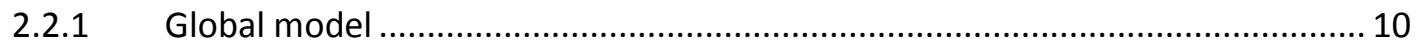

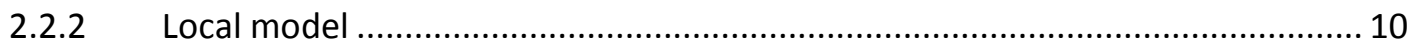

2.2.3 Definition of wave climate and extremes .......................................................... 12

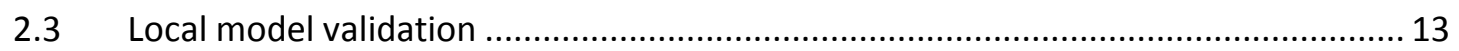

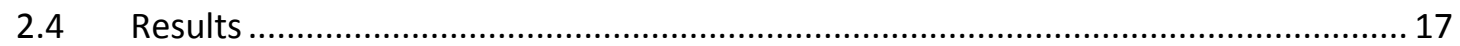

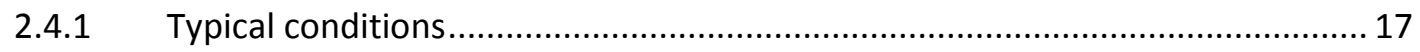

2.4.2 Directional wave climatologies ........................................................................ 19

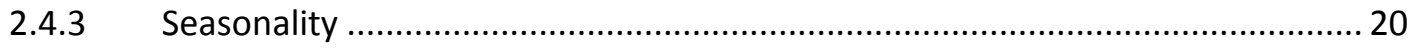

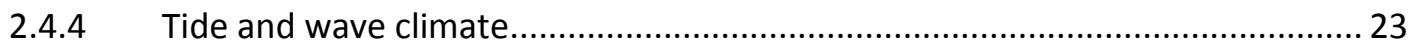

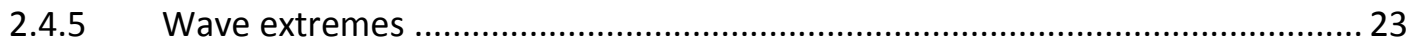

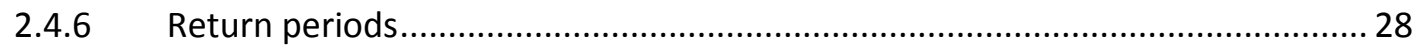

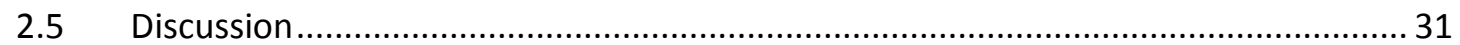

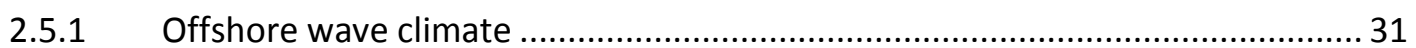

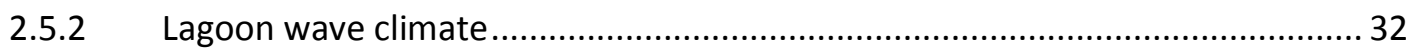

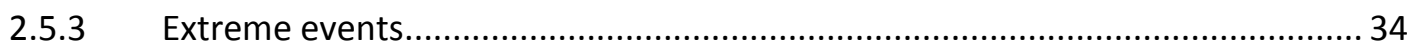

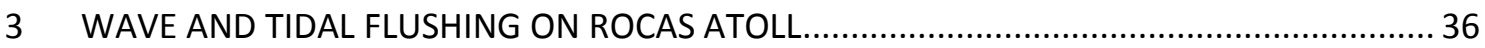

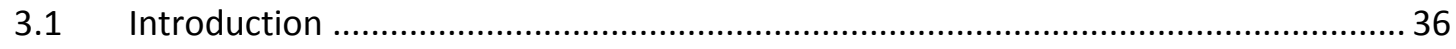

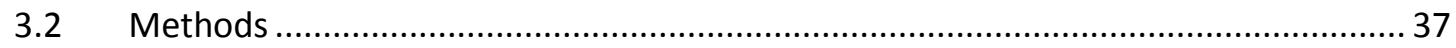

3.2.1 Measurements of waves, currents and water level........................................... 37 


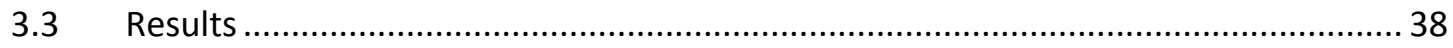

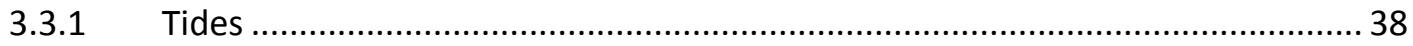

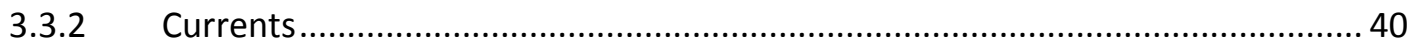

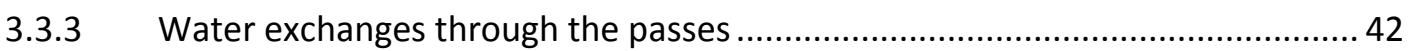

3.3.4 Waves, current at larger reef pass, and lagoon water level .............................. 42

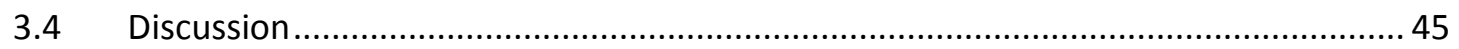

3.4.1 Atoll morphology and flow pattern............................................................... 45

3.4.2 Drag coefficient at the main reef passage ......................................................... 47

3.4.3 Tidal influence on wave pumping …….......................................................... 48

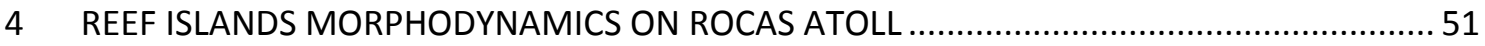

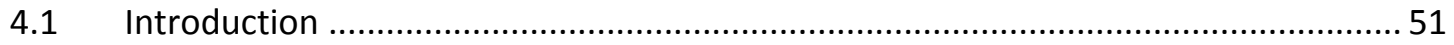

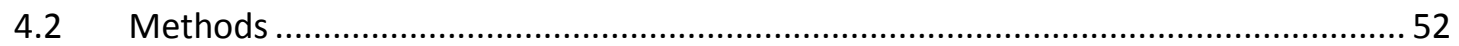

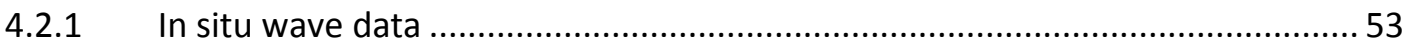

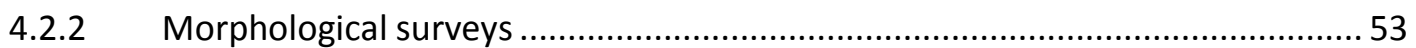

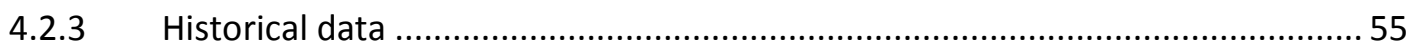

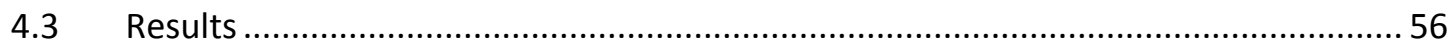

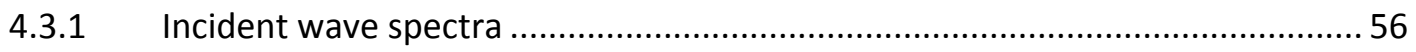

4.3.2 Reef islands and shingle bank morphology .................................................... 57

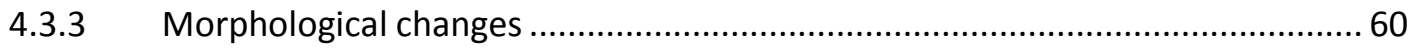

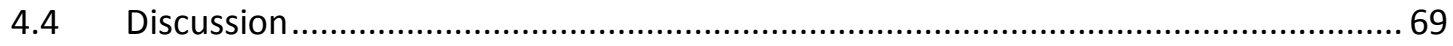

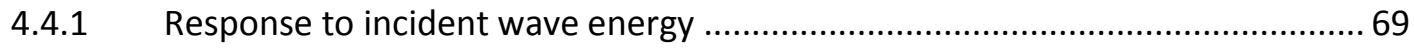

4.4.2 Morphological adjustment of reef islands ........................................................ 71

5 RESPONSE OF WAVE REFRACTION TO SEA LEVEL RISE ON ROCAS ATOLL: IMPLICATIONS

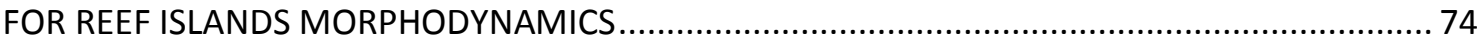

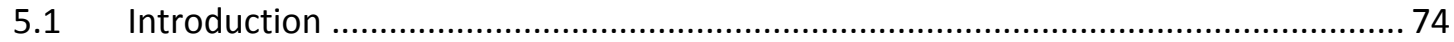

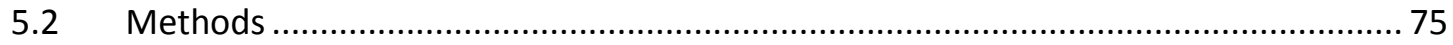

5.2.1 Topographic and bathymetric surveys ............................................................ 75

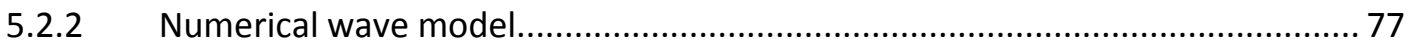

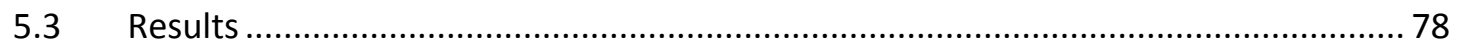

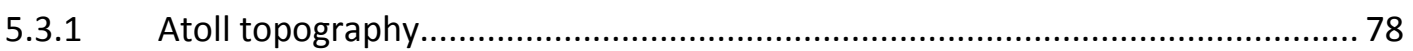

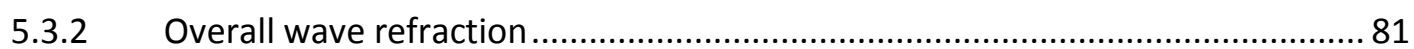

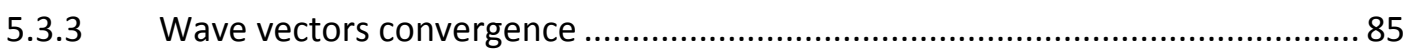

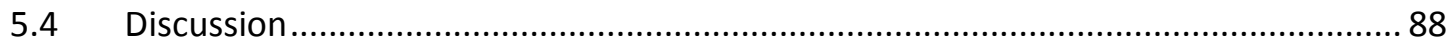

5.4.1 Atoll topography, wave refraction and reef islands distribution ........................ 88 
5.4.2 Sea level rise and wave vectors convergence displacement ..............................89

5.4.3 Implications for reef island morphodynamics .................................................... 90

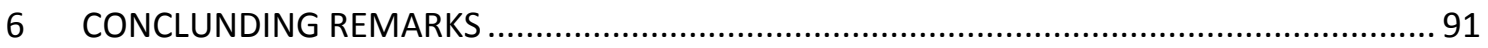

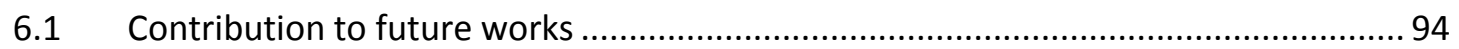

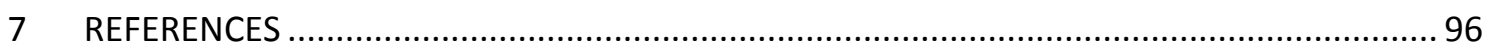

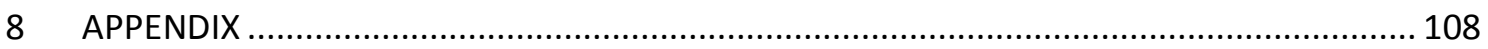




\section{Acknowledgements}

O desenvolvimento desta pesquisa foi possível graças a um conjunto de pessoas que contribuíram de diferentes formas e em diferentes momentos na minha trajetória, mas que foram essenciais na sua elaboração e conclusão. Gostaria de agradecer especialmente a Eduardo Macedo, que esteve sempre presente durante a construção desta ideia, quando Rocas era ainda "um sonho distante"; por ser o principal incentivador deste projeto, desde o retorno de sua primeira expedição ao atol, contribuindo com importantes sugestões e discussões ao longo de todo o trabalho. Sou muito grata pelo seu apoio, incentivo, paciência e por todos os momentos de descontrações vividos nestes últimos anos.

Ao meu orientador, Eduardo Siegle, gostaria de agradecer por toda a confiança depositada no desenvolvimento deste projeto, todas as sugestões de melhoria, ensinamentos e ótimo convívio. Participar do Laboratório de Dinâmica Costeira foi uma ótima experiência tanto profissional quanto pessoal. Queria estender meus agradecimentos a todos os meus amigos do Instituto Oceanográfico, pelas boas conversas, cafezinhos, ajudas em dúvidas do dia-dia de pesquisa etc. Em especial, agradeço a Ana Amélia, Bruna, Caio, Carol, Dalton, Diana, Filipe, Giba, Hélio, Júlia, Juliana Damasceno, Juliana Ribeiro, Lilian, Mariana, Mirela, Nery, Paulo, Tito. Tenho certeza que vamos continuar em contato por muito tempo.

Gostaria de agradecer muito a Maurizélia Brito, por acreditar nesta pesquisa e apoiar todas nossas expedições. Mais ainda, gostaria de agradecer a ela por todo seu esforço em proteger aquele pequeno, mas importantíssimo ambiente. Nunca achei que fosse conhecer um lugar tão lindo e preservado e sei que a sua história de vida e a história de conservação do atol estão completamente ligadas. Gostaria de agradecer também aos colegas que participaram das expedições: Jarian, Miguel, Natan, Tiago, Gleice e Igor pela ajuda com os levantamentos de campo e pelos mergulhos e passeios no atol. E novamente a Eduardo Macedo, não só pelas aventuras naquele ambiente incrível, mas também pelos vários quilômetros que percorremos com o GPS. Também sou grata à tripulação e comandante do Borandá, Zeca e Ceará, pela ótima companhia durante a navegação até o atol e pela ajuda com o fundeio dos ADCPs externos. Sem dúvida as expedições foram a parte mais esperada desse trabalho. Este trabalho teve o apoio financeiro da Fundação de Apoio a Pesquisa do Estado de São Paulo (FAPESP 2011/22663-2).

Por último, mas com certeza não menos especial, gostaria de agradecer a minha família, em especial aos meus pais, Daesy e Petrônio, por todo a apoio durante todas as etapas da minha vida; por todos os fins de semana na praia quando criança, que sem dúvida contribuíram para o meu gosto por oceanografia. Tenho certeza que meu pai estaria orgulhoso! 


\section{Resumo}

Os processos induzidos por ondas e marés em atóis são importantes forçantes da circulação, transporte de sedimentos e troca de água entre a laguna e oceano, que por sua vez, afetam a formação e estabilidade das suas ilhas recifais. Através da combinação de modelos numéricos e experimentos de campo, este trabalho teve por objetivo o estudo dos processos induzidos por ondas e marés no Atol das Rocas e suas implicações na dinâmica de sedimentos das ilhas recifais, considerando os efeitos do aumento do nível do mar. Experimentos de campo forneceram séries temporais de ondas, correntes, mares e informações topo-batimétricas ao longo de três expedições ao Atol das Rocas, totalizando 75 dias de levantamentos. Um modelo numérico de propagação de onda foi implementado e validado para a região.

Os resultados demonstram que o mecanismo de circulação e de propagação de ondas, que afetam as ilhas recifais, é controlado pela interação do clima de onda com a topografia do atol, sendo fortemente modulados pelas flutuações de meso-maré. 0 clima de ondas ao largo do atol é dominado por vagas formadas pelos ventos alísios de sudeste e por ondulações geradas em latitude médias de ambos os hemisférios. A incidência das ondulações no atol apresenta uma forte sazonalidade enquanto que a vagas de sudeste persistem ao longo do ano. As ondas ao largo são filtradas pela borda do atol, resultando em um clima de ondas na laguna mais homogêneo e controlado pela maré e topografia do atol. Eventos extremos ao largo são ocasionados por ondulações energéticas tanto do hemisfério sul quanto do hemisfério norte. No entanto, os eventos extremos na laguna só ocorrem quando os eventos energéticos ao largo ocorrem em conjunto com maré alta de sizígia.

As vagas que quebram constantemente no lado do atol exposto ao vento são importante forçantes na circulação geral do atol. A partir do processo de quebra, elas são responsáveis por bombear água para a laguna, criando intensas correntes geradas por ondas que fluem do lado exposto para o lado protegido. Este processo, modulado pela maré, resulta em variações periódicas da importância relativa da maré no controle da circulação. Foi também observada a presença de ondas longas dentro da laguna (infragravitacionais) provocada pela quebra do espectro de ondas incidente no recife. Através desses dados, o volume de fluxo de troca de água e o coeficiente de atrito no Barretão foram estimados. O mecanismo descrito para Rocas pode ser aplicado em outros atóis semelhantes sob regime de mesomaré, os quais ainda hoje têm sido pouco estudados.

As ilhas recifais estão localizadas no lado protegido do atol e apresentam maiores modificações morfológicas em resposta a incidência de ondulações de norte. No entanto, não foi observado um balanço sedimentar negativo em escala diária e sazonal, com partes erodidas da ilha sendo compensadas por acresção nas partes 
adjacentes. Em escala decadal, a Ilha do Farol apresentou substancial acréscimo em área (59.6\% em 75 anos), modificando sua forma alongada para uma forma de ferradura com formação de uma depressão central. Durante esse processo, o lado da ilha voltado para o oceano foi erodido, enquanto que o lado da laguna foi acrescido, caracterizando uma migração da ilha para a laguna. Não foram observadas modificações significativas na ilha do Cemitério, a qual está estabilizada atualmente pela presença de sedimentos consolidados expostos nos dois lados da ilha. Os resultados indicam que as ilhas são feições resilientes, capazes de se ajustar as mudanças nas condições de contornos.

No processo de refração das ondas, devido a sua morfologia, o Atol das Rocas funciona com uma plataforma recifal. Os vetores de ondas convergem no lado protegido e zonas de interferência podem ser observadas no lado exposto e na parte central da laguna. A localização das ilhas e do banco Zulu está relacionada com o padrão de refração, que promovem locais favoráveis à deposição de sedimentos no atol. 0 aumento do nível do mar promove um deslocamento na posição de convergência das ondas de acordo com o tipo de onda incidente. Isto indica que neste cenário futuro, as áreas deposicionais podem se tornar mais instáveis no atol promovendo o deslocamento das ilhas, mas não necessariamente em uma erosão generalizada.

Os resultados obtidos no desenvolvimento deste trabalho forneceram uma série de informações inéditas para o Atol das Rocas permitindo elucidar questões importantes acerca da capacidade de modificações das ilhas recifais em resposta aos processos oceanográficos dominantes no atol. 


\section{Abstract}

Wave and tides are important drivers of circulation, sediment transport and water exchanges between ocean and lagoon in atolls, which in turn, affect the formation and stability of reef islands. Through a combination of field measurements and numerical modelling, this thesis examines the wave- and tidally-induced processes at Rocas Atoll and their implications on sediment dynamics. This comprehends the morphological responses of reef islands, including the effects of sea level rise. Wave, current, tide and topo-bathymetric data were collected during three expeditions to Rocas Atoll, totaling 75 days of in situ measurements. A spectral wave model has been implemented and validated for the Rocas Atoll.

Our results demonstrated that the mechanism of circulation and the wave propagation that affects the reef islands morphology are controlled by the interaction of wave climate with the atoll topography. Being under mesotidal setting, there is a strongly tide modulated process in Rocas. The offshore wave climate is dominated by southeast trade wind wave and swell from south and north mid-latitude hemispheres. The swell occurrence has a marked seasonality whereas the southeast wind waves persist during the whole year. Offshore waves are filtered by the reef rim resulting in a more homogenous lagoon wave climate, which is controlled by tide and reef topography. Offshore extreme events are promoted by energetic swells, either from north or south hemispheres. However, extreme events in the lagoon only occur when such offshore events are combined with spring high tide.

Wind waves that persistently break on the windward side of the atoll plays an important role on the overall circulation. They pump water into lagoon creating wavegenerated currents that flow from the windward to the leeward side of the atoll. A water level threshold exists due to the large tidal oscillation, blocking inflow by wave pumping at lower water levels. This results in periodic variations in the relative importance of tidal controls in lagoon circulation along a tidal cycle interval. Such mechanism described for Rocas Atoll can be extended to other similar mesotidal atolls.

The reef islands are located on the leeward of the atoll and present higher morphological changes in response to northern swell. However, no significant net erosion was observed on daily and seasonal time scale, with eroded parts being compensated by accretion on adjacent parts. Conversely, Farol Island had a substantial accretion on a decadal time scale changing from an elongated ridge morphology to horse-shoe shape with three ridges and an intertidal central depression. The changes in the planform configuration were characterized by ocean shoreline erosion and lagoon shoreline progradation, representing net lagoonward migration. Cemitério Island remains stable for the same period, anchored by exposed consolidated 
sediments on both shores. Results indicate the resilient nature of reef islands and their potential adjustment to changes in boundary conditions.

In terms of wave refraction, Rocas Atoll works as a platform reef due to its morphology. Wave vectors converge mainly on the leeward side and an interference zone can be observed from the windward side trough the lagoon. Such refraction pattern controls the location of reef islands and shingle bank on Rocas. Sea level rise displaces the wave convergence zone according to the incident wave incidence climate (swell or wind wave). This indicates that under sea level rise scenarios areas prone to sediment accumulation may become less stable, although not implying in the erosion of reef islands.

The results provided an unprecedented dataset for Rocas Atoll, which improves the understanding about the mechanisms that control its reef islands morphodynamics and their ability adapt to changes in boundary conditions. 


\section{Publications produced during the PhD Candidature}

Peer-Reviewed:

Costa, MBSF; Araújo, M; Araújo, TCM; Siegle, E. Influence of reef geometry on wave attenuation on a Brazilian coral reef. Geomorphology (in press).

doi:10.1016/j.geomorph.2015.11.001

Costa, MBSF; Macedo, EC, Valle-Levinson, A; Schettini, CAF; Siegle, E. Wave and tidal flushing in a mesotidal near-equatorial atoll. Journal of Geophysical Research (in prep.).

Costa, MBSF and Siegle, E. Wave climate and extremes on a mesotidal atoll lagoon (Rocas Atoll, South Atlantic Ocean) (in prep.).

Costa, MBSF; Macedo, EC; Siegle, E. Reef islands morphodynamics in a near-equatorial shallow lagoon atoll. (in prep.).

Costa, MBSF and Siegle, E Response of wave refraction to sea level rise on Rocas atoll: implications for reef islands morphodynamics. (in prep.).

Conference Presentations:

Costa, MBSF; Araújo, M; Araújo, TCM; Siegle, E. Influence of reef geometry on wave attenuation on a brazilian coral reef. 12th International Coral Reef Symposium. Queensland, Australia. 2012.

Costa, MBSF; Macedo, EC. ; Siegle, E. Morphological response of reef island on Rocas Atoll (South Atlantic Ocean) to seasonal energetic wave conditions. 8th international conference in geomorphology. Paris, França. 2013.

Costa, MBSF; Macedo, EC; Couceiro, MAA; Contti Neto, N; Gagliardi, MH; Siegle, E.. Evolução geomorfológica do pontal arenoso da desembocadura do Rio Preguiças, Lençois Maranhenses, MA, Brasil. XIV Congresso Da Associação Brasileira de Estudos do Quaternário. Rio Grande do Norte, Brasil. 2013.

Costa, MBSF; Araújo, M; Araújo, TCM; Siegle, E. Wave - reef interaction controlling coastal processes: Northeast Brazil. 17th biennial Ocean Sciences Meeting, Hawaii, USA. 2014.

Costa, MBSF; Macedo, EC; Siegle, E. Shoreline changes analysis at Rocas Atoll as a tool to improve spatial planning strategies. 17th biennial Ocean Sciences Meeting, Hawaii, USA. 2014.

Costa, MBSF; Macedo, EC; Schettini, CAF; Siegle, E. Effects of tides and waves on the flushing rate of an atoll lagoon. $17^{\text {th }}$ Physics of Estuaries and Coastal Seas. Porto de Galinhas, Brasil. 2014.

Costa, MBSF. Climatologia e extremo de ondas no Atol das Rocas e em Fernando de Noronha. I Encontro de Pesquisa de Fernando de Noronha, São Pedro e São Paulo e Atol das Rocas: Como integrar a gestão das Unidades de Conservação (UCs) em ilhas oceânicas do Nordeste?

Fernando de Noronha, Brasil. 2015. 


\section{List of Figures}

Figure 1.1. Rocas Atoll.

Figure 1.2. Distribution 304 atolls (a) sizes and (b) their maximum lagoon depths from Pacific, Indian and Atlantic Oceans. Rocas atoll is highlighted by a red dot on the graphs. For comparative purposes, letters on gray dots refers to Rose Atoll (Rs) and Rangiroa Atoll, Tuamotu (Ra) both on Pacific Ocean, Cocos-Keeling Atoll (Cc) and South Maalhosmadulu Atoll, Maldives ( $\mathrm{Sm}$ ) both on Indian Ocean. (c) Histogram showing the size frequency distribution. Database from GSA Data Repository item 2001075 available online at ftp://rock.geosociety.org/pub/reposit/2001/2001075.pdf.

Figure 2.1. Global framework to obtain offshore and lagoon wave databases.

Figure 2.2. Computational mesh resolution of the domain modeled.Computational mesh resolution of the domain modeled.

Figure 2.3. Bathymetric resolution used in the domain modeled.

Figure 2.4. Deployment of the (a) offshore and (b) lagoon ADCPs at Rocas Atoll.

Figure 2.5. Time series of the difference of the modeled $(\mathrm{Hmo})$ and measured $(\mathrm{Hme})$ significant wave height at (a) offshore and (b) lagoon station. Model accuracy statistics: (c,e) histogram of model error and $(b, f)$ scatter diagram of modeled $(\mathrm{Hmo})$ and measured $(\mathrm{Hme})$ significant wave height for offshore and lagoon station. 15

Figure 2.6. Time series of the measured $(\mathrm{Hme})$ and modeled $(\mathrm{Hmo})$ significant wave height used for validation at the (a) offshore and (b) lagoon station.

Figure 2.7. Time series of the difference of the modeled $(\mathrm{Hmo})$ and measured $(\mathrm{Hme})$ significant wave height plot against tide at lagoon station. 17

Figure 2.8. Histograms of $(a, d)$ significant wave height, $(b, e)$ peak period and $(c, f)$ peak direction in the Rocas Atoll lagoon and offshore between 1980 and 2014

Figure 2.9. Wave climate at offshore and at lagoon of Rocas Atoll. (a) Directional histogram of significant wave height $(\mathrm{m})$ and $(\mathrm{b})$ directional histogram of the peak period $(\mathrm{s})$ of incident waves

Figure 2.10. Monthly directional histograms of the significant offshore wave height (Hs). ...... 21

Figure 2.11. Monthly directional histograms of the offshore peak period (Tp).

Figure 2.12. Monthly directional histograms of the significant lagoon wave height (Hs).

Figure 2.13. Monthly directional histograms of the lagoon peak period (Tp). 22 
Figure 2.14. (a) Scatter plot of the tide (b) and offshore and lagoon wave and tide height. (c) Example of time series during September 2014 demonstrating the tidal oscillation and offshore and lagoon wave heights.

Figure 2.15. (a) Scatter plot of combined occurrences of significant wave height (Hs) and peak period (Tp) and (b) histogram of wave power (P) during the 35-year interval. The color scale represents the wave intensity classes. The values above each bar are the rounded percentage of occurrence values.

Figure 2.16. Directional histogram of wave power $(P)$ for the (a) total dataset and (b) the class of extremes only $(P \geq 50 \mathrm{~kW} / \mathrm{m})$.

Figure 2.17. Probability and quantile plots corresponding to the 35-year maximum values fit to the Generalized Extreme Value (GEV) distribution. 28

Figure 2.18. Return period of wave extremes estimated using the GEV distribution based on the 35-year time series of $\mathrm{Hs}, \mathrm{Tp}$, and $\mathrm{P}$ for offshore and $\mathrm{Hs}, \mathrm{Tp}$, and $\mathrm{P}$ for the lagoon. .29

Figure 3.1. The Rocas Atoll. Mooring locations indicated by black squares. 38

Figure 3.2. Water level oscillation samples for (a) ocean (station ES2) and lagoon (IL2) during the second leg (July 2013) and for (b) the reef passages (stations IBO3 and IBA3) during the second campaign (December 2013).

Figure 3.3. Directional histograms of measured flows (m.s-1).

Figure 3.4. Synchronous water elevation and current vectors at (a) southeast (F1) of the atoll, (b) lagoon (F2) and (c) larger (F3) reef passages during first expedition (July 2013).

Figure 3.5. Synchronous water elevation and current vectors at the (a) larger (S1) and smaller (S2) reef passages during second expedition (December 2013).

Figure 3.6. (a) Observed incident significant wave height ( $\mathrm{m}$ ), (b) peak period ( $\mathrm{s}$ ) and (c) wave energy spectra ( $\mathrm{m} 2 \mathrm{~Hz}^{-1}$ ) at offshore (station $\mathrm{F} 1$ ). (d) Instantaneous and tidally filtered currents in the larger reef pass (station F3). (e) Observed incident significant wave height $(m)$ ( $f$ ), peak period (s) and (g) wave energy spectra $\left(\mathrm{m}^{2} \mathrm{~Hz}^{-1}\right)$ at the lagoon (station $\mathrm{F} 2$ ).....

Figure 3.7. (a) Comparison of water level records inside (station IBO2) and outside (station ES2) the lagoon. Note the lower water levels in the lagoon at every first half of rising tides (gray boxes). (b) Histogram of the water level difference between lagoon and ocean.

Figure 3.8. Water level (a) drag coefficient in the main channel (b) and drag coefficient values frequency distribution.

Figure 3.9. Scatter diagram of current velocity and direction over the tide level for $(a, b)$ the larger and $(c, d)$ smaller passages. 
Figure 3.10. (a) Water level heights along the reef rim. Distance in meters represents the perimeter of the reef rim (clockwise from $A$ to $B$ ). (b) Reef rim during low tides. Note that no water is flowing over the reef rim due to wave breaking at the captured tidal stage.

Figure 3.11. General flow model of Rocas Atoll along a tidal cycle. 50

Figure 4.1. (a) Location of Rocas Atoll. (b) ADCPs positions at first (E1) and second expedition (E2). Example of topographic survey points for the (c) Farol Island, (d) Cemiterio Island and (e) Zulu shingle bank during expedition 1. Satellite images from Google Earth.

Figure 4.2. (a) Time series of wave spectra and (b) mean directional wave energy distribution during first expedition (November 2012). Means of wave energy distribution were calculate for each frequency at each direction.

Figure 4.3. (a) Time series of wave spectra and (b) mean directional wave energy distribution during second expedition (July 2013). Means of wave energy distribution were calculate for each frequency at each direction.

Figure 4.4. Digital Elevation Model (DEM) of Farol and Cemitério islets and Zulu shingle bank with examples profiles from the northwest (A) to the southeast (B) and from the southwest (C) to the northeast (D). The numbering 1, 2, 3 and 4 on profile $b$ correspond to NW oceanward ridge, central ridge, central depression and lagoonward ridge, respectively of Farol Island. Conversely, the numbering 5 and 6 on profile c correspond to oceanward ridge and the lagoonward ridge of Cemitério Island.

Figure 4.5. (a) Intersection of beach sediments with the reef surface (toe of the beach) of Farol Island. (b) Beachrock on the oceanward beach of Cemitério Island. (c) Consolidated sediments on the lagooward beach of Cemitério Island. (d) Top of Zulu shingle bank during high neap tide.

Figure 4.6. Digital elevation model (DEM) of Farol Island generated from surveys conducted during first expedition (a) 01/11/2012 (b) 17/11/2012 (c) 29/11/2012 and the second expedition (d) 06/07/2013 (e) 14/07/2013 (f) 20/07/2013.

Figure 4.7. Digital elevation model (DEM) of Cemitério Island generated from surveys conducted during first expedition (a) 02/11/2012 (b) 18/11/2012 (c) 30/11/2012 and the second expedition (d) 08/07/2013 (e) 15/07/2013 (f) 21/07/2013.

Figure 4.8. Digital elevation model (DEM) of Zulu shingle bank generated from surveys conducted during first expedition (a) 12/11/2012 and the second expedition (b) 07/07/2013 (c) 22/07/2013.

Figure 4.9. Difference in elevation between the last and the first survey on each expedition. Red colors represent loss of sediment whereas blue color represents gaining. Gross volume accretion and gross volume erosion are indicating by positive number and negatives numbers, respectively. Net volume change is indicating by bolds numbers. The date of each survey is showed on Table 4.1. They correspond to an interval of approximately 30 days. 
Figure 4.10. Difference in elevation of (a) Farol and (b) Cemitério reef islands and (c) Zulu shingle bank between two expeditions. Red colors represent loss of sediment whereas blue color represents gaining. Gross volume accretion and gross volume erosion are indicating by positive number and negatives numbers, respectively. Net volume change is indicating by bolds numbers. The date of each survey is showed on Table 4.1. They correspond to an interval of approximately 6 months (between two seasons).

Figure 4.11. Photographs of Farol Island from (a,b) 1939 and (c,d) 2014. The numberings 1, 2, 3 , and 4 correspond to the oceanward ridge, central ridge, central depression, and lagoonward ridge, respectively.

Figure 4.12. Photographs of Farol Island at different times (from 1939 to 2014), showing the growth of the island towards the lagoon and the erosion of the oceanward beach. The year of each photograph is displayed on the upper right corner. The numberings $1,2,3$, and 4 correspond to the oceanward ridge, central ridge, central depression, and lagoonward ridge, respectively

Figure 4.13. Comparisons between a (a) small reef island on Keeling Island (Pulu Kembang) and (b) Farol Island on Rocas Atoll. Note the difference in orientation of the shallow internal lagoon (termed lagoonlet by Guppy 1889) in respect to the reef edge. The figures are not scaled...... 73

Figure 5.1. (a) Location of Rocas Atoll. (b) Description of Rocas Atoll. (c) Bathymetric and topographic survey points for the lagoon, reef islands, shingle bank and reef rim. Black dots represent the survey track for the dry parts of atoll using the rover on a backpack kit during low tides. Orange dots represent the survey track for the lagoon and sand apron using the rover coupled to an echosound on a monohull vessel during high tides.

Figure 5.2. (a) Digital elevation model of Rocas Atoll. (b) Profile section from the leeward side (NW) to the windward side (SE). (c) Profile section of the reef rim perimeter (A to C); letter B correspond to Barretinha passage. Note: the reef boulders and the submerged depressions on the reef rim were not detailed in the survey.

Figure 5.3. Distribution of wave power $P(\mathrm{~kW} / \mathrm{m})$ on Rocas Atoll for north southeast wind wave condition (a) $S L R=0$ and (b) $S L R=1$; south swell wave condition (c) $S L R=0$ and (d) $S L R=1$; and north swell wave condition (e) $S L R=0$ and (f) $S L R=1$; Data is present in logarithmic scale to show details of $\mathrm{P}$ distribution on shallow waters. Linear values of $\mathrm{P}$ are display besides the logarithm scale. Letters on map correspond to Farol islet (F), Cemitério islet (C) and Zulu shingle bank (Z) locations. Wave vectors are not scaled....

Figure 5.4. Cross-profile of significant wave height (Hs) and peak wave period (Tp) from the leeward to windward over a tidal cycle for the SLR=0 scenario. (a) Northern swell condition, (b) southern swell condition and (c) southeastern wind waves. Vertical lines indicate the reef rim (Rim), Farol Island (F), lagoon (Lagoon) and Zulu shingle bank (Z) limits.

Figure 5.5. Spatial wave window action during (a) intermediary and (b) low tide. 85 
Figure 5.6. Details of wave vectors at the reef islands location. Letters on map correspond to Farol Island (F), Cemitério Island (C). Letters on map correspond to Farol islet (F), Cemitério islet (C). Wave vectors are not scaled.

Figure 5.7. Details of wave vectors convergence at the reef islands location. Letters on map correspond to Farol Island (F), Cemitério Island (C). Wave vectors are not scaled...

Figure 6.1. Evolution models of reef islands (Woodroffe et al., 1999). In each model, the left sides represent the sides facing the ocean (oceanward), and the right sides represent the sides facing the lagoon (lagoonward). The dashed box indicates the model into which Farol Island fits. 


\section{List of Tables}

Table 2.1. Wave intensity classification based on wave power.

Table 2.2. Typical and extreme values of significant wave height and peak period for Rocas Atoll.

Table 2.3. Summary of the maximum annual significant offshore wave heights (Hs) and peak period (Tp), with the associated hemisphere of incidence; and maximum annual offshore peak periods (Tp) and annual significant wave heights ( $\mathrm{Hs}$ ), with the associated hemisphere of incidence.

Table 2.4. Summary of the maximum annual significant lagoon wave heights (Hs) and peak period (Tp), with the associated hemisphere of incidence; and maximum annual offshore wave peak periods (Tp) and annual significant wave heights ( $\mathrm{Hs}$ ), with the associated hemisphere of incidence.

Table 2.5. Estimates of wave extremes for the various return periods, based on the 35-year offshore time series for Rocas Atoll.

Table 2.6. Most energetic wave events recorded at offshore of Rocas Atoll in the last 35 years (1980-2014), using the occurrence of $1 \%$ of the total number of events of the classes of extremes (> $50 \mathrm{~kW} / \mathrm{m})$ and considering the peak of each event.

Table 3.1. Instruments deployment information. Their position is shown in Fig 1.

Table 3.2. Tidal harmonic constituents based on water level records at open ocean (Station ES2), lagoon (Station IL2) and the larger reef passage (Station IBO2).

Table 3.3. Mean water flow estimates through the reef passes.

Table 4.1. Instruments deployment information. The instruments' position is shown in Figure 4.1 .

Table 4.2. Date of each topographic survey conducted on reef islands and shingle bank of Rocas Atoll.

Table 4.3. Summary of the topographic characteristics of the reef islands on Rocas Atoll. Estimation of perimeter, area and volume were horizontally limited by the toe of the beach (TOB) and the vegetation line (VL). Volumes estimations were vertically limited by the height of the surrounding reef flat. 60

Table 5.1. Summary of offshore dominant wave conditions on Rocas Atoll used to construct the wave propagation scenarios.

Table 5.2. Summary of wave vector convergence location and displacement on $S L R=0$ and $S L R=1$ scenarios for each incident wave condition. 


\section{Chapter 1}

\section{INTRODUCTION}

Atolls are ring-shaped ocean reefs formed by an internal lagoon and islands of unconsolidated sediments (Barry et al., 2007; Woodroffe et al., 1999). These islands, commonly known as reef islands, are recent geological formations (Holocene), formed by physical processes acting on biogenic sediments (Gourlay, 1988). They mainly consist of carbonate sands and gravels, both originated from and deposited on the reef platforms of the atoll system itself (Kench et al., 2005; Stoddart and Steers, 1977; Yamano et al., 2000).

Although atolls are superficially similar to each other, they significantly differ with regard to the number, size, continuity, and morphology of the reef islands (Barry et al., 2007). They typically have a low elevation ( $<3 \mathrm{~m}$ above the mean sea level), small area, vegetation in the central part, and narrow beaches around the entire perimeter (Kench and Brander, 2006a). The beach sector facing the ocean is typically formed by thicker sediments and with relative stability, except during the incidence of more energetic events. On the side facing the lagoon, the beach consists of finer sediments and shows greater morphological changes in response to processes that occur within the atoll (Sato and Yokoki, 2010).

The formation and stability of reef islands are related to sediment transport inside the atoll, whose main forces are waves and tides (Callaghan et al., 2006; Gourlay, 1988). The relative importance of these variables depends on the topography of the atoll edge and the local wave climate and tidal regimes. When the atoll has wide openings on the edge that are deep compared to the wave height and tidal range, the flow inside will mainly be generated by tides, and the lagoon water level will fluctuate according to their range. Conversely, when the atoll has a nearly uninterrupted edge whose elevation is approximately at the same level as the mean sea level (MSL), the waves might cause a significant flow during the surf process. In this case, the side of incidence of the most energetic waves will experience greater water rise that will overflow into the protected side (Callaghan et al., 2006). Wave-induced currents are key forces in sediment transport from the shallow parts of the reef structure, especially with regard to the sandy fraction (Gourlay, 1988). Its intensity is related to the magnitude of the wave set-up, whose increase is directly proportional to the wave height and period increase at the time of breaking and inversely proportional to the water level on the reef's edge (Nelson and Lesleighter, 1985).

Waves that do not dissipate all of their energy on the reef's edge, with the surf process, are able to propagate into the atoll and reach the beach sector of the sediment islands (Gourlay, 1988). This process also experiences tidal modulation, 
wherein, during low tides, waves mostly break on the atoll edge and, during high tides, waves partly manage to propagate into the atoll, dissipating their energy on the plateau and reef-islands (Kench and Brander, 2006b). Several authors show that the interaction between waves and reef structures may result in a wave energy reduction that ranges from $20 \%$ to $47 \%$ in the reef side and from $50 \%$ to $90 \%$ in the edge (Costa et al., 2015; Gerritsen, 1980; Kench and Brander, 2006a; Lugo-Fernández et al., 1998a; Roberts, 1980). These studies demonstrate that the leading factors that control the degree of wave attenuation include the geometry of the reef structure (elevation, slope, and width of the top), the relative depth between water level and the reef top, and the characteristics of the incident waves themselves (Costa et al., 2015; Gourlay, 1994; Hardy and Young, 1996). The wave energy that is able to propagate into the atoll plays a key role in activating the geomorphological and sediment transport processes and, therefore, in the formation and morphological changes of sandy islands (Brander et al., 2004; Gourlay, 1988; Kench, 1998a; Roberts et al., 1992).

In addition to short-term morphological changes caused in the time scale of a tide cycle, or in the seasonal scale of the wave climate, long-term changes may occur that result from global climate change (Gourlay, 1988). In particular, the rising sea level and frequency of extreme events are some of the most notable impacts that climate change may have on the sediment dynamics of an atoll (IPCC, 2007; Leatherman and Beller-Simms, 1997; Yamano et al., 2005). Most projections suggest that sea level may increase on the order of $0.5 \mathrm{~m}$ to $1.0 \mathrm{~m}$ by the year 2100 (Sato and Yokoki, 2010). Factors such as the low topography of reef-islands and the importance of the water level in the physical processes that occur in an atoll contribute to the vulnerability of these environments, based on climate projections for the next century (Woodroffe, 2008). Accordingly, the use of numerical models may contribute to developing future scenarios concerning the sediment dynamics of these oceanic environments (Kench and Cowell, 2000; Sato and Yokoki, 2010; Sheppard et al., 2005; Storlazzi et al., 2011; Yokoki et al., 2006).

Approximately 500 atolls exist worldwide, and approximately 400 of them are in the Pacific Ocean (Kayanne et al., 2005) and 27 in the Caribbean Sea (Stoddart, 1965).The only atoll in the South Atlantic is located off the coast of Brazil: Rocas Atoll (Kikuchi, 2002). Rocas Atoll has a nearly continuous elliptical reef rim, cut by a 10 -m-deep main passage, a shallow lagoon up to 8 meters deep, and two reef islands, one island with an elevation of $3 \mathrm{~m}$ above MSL and $1.800 \mathrm{~m}$ of beach perimeter and another smaller island with an elevation of $2 \mathrm{~m}$ and $950 \mathrm{~m}$ of beach perimeter (Kikuchi, 2002; Pereira et al., 2010). Since 1993, these islands have harbored a research station managed by the Chico Mendes Institute of Biodiversity Conservation (Instituto Chico Mendes de Conservação da Biodiversidade - ICMBio), which is responsible for protecting this important ecosystem. The research station was recently replaced in 2007 because of beach erosion (Soares et al., 2010). 
Several studies about reef geology and sedimentology have been conducted at Rocas Atoll, especially since the establishment of the ICMBio research base (Gherardi and Bosence, 2005, 2001; Kikuchi and Leão, 1997; Pereira et al., 2013, 2010; Soares et al., $2011,2009 a)$. However, no study has yet attempted to quantify and analyze the waveand tide-induced processes in the sediment transport and morphology of the reef islands at the Rocas Atoll. Furthermore, studies focusing on the processes controlling the sedimentary dynamics of that environment are relevant, considering the possible impacts of climate change on atolls worldwide.

The methodological strategy of this thesis was based on the hypotheses that waves and tides are the main forcing on the lagoonal processes, including circulation and sediment transport. This is expected due to Rocas Atoll characteristics, particularly the small-size reef rim, shallow lagoon and mesotidal regime. The water depth over the reef rim, in turn, plays an important role in modulating the wave propagation and dissipation. Thereby, rising sea level projected as a consequence of climate changes would increase the water depth over the reef rim, affecting the reef islands morphodynamics. In this work, we first attempt to study the effects of wave and tides on the circulation and sediment transport of Rocas Atoll, and then the resulting effects of sea level rise on the reef islands.

\subsection{Objectives}

Through a combination of field measurements and numerical modelling, this thesis examines the wave- and tide-induced processes at Rocas Atoll and their implications on sediment dynamics, particularly the morphological responses of reef islands. Future scenarios considering the climate predictions for 2100 are also examined in order to also contribute to the management of this environment.

The following specific objectives are proposed to achieve the overall goal:

- Analysis of offshore and lagoon wave climate and extremes on Rocas Atoll.

- In situ measurements and analysis of the variables controlling sediment dynamics at Rocas Atoll, including the waves, tides, and currents induced by these forces;

- Analysis of the process of tidal modulation of waves and its effect on reef islands daily, seasonal and decadal morphological changes;

- Application of a numerical model to simulate wave propagation and their implication on the reef islands morphodynamics, considering future scenarios of sea level rise. 


\subsection{Study area}

Located $250 \mathrm{~km}$ off the northeast Brazilian coast, Rocas Atoll (3.511 S, 33.491W) is the only atoll on the South Atlantic Ocean and the first Brazilian marine protected area (Figure 1.1). Rocas Atoll was designated as a Biological Reserve (Reserva Biológica do Atol da Rocas) in 1979 by the Brazilian Government, a restricted category of marine protection in which research and education are the only allowed activities. The protected area comprises surrounding waters of Rocas Atoll above the depths of 1000 m. In 1993, the first research base was built on Rocas (Woelffel and Alvarez, 2009) and since then Rocas is continually occupied by a team of approximately four people (including researchers and managers) that alternate each month for research and monitoring activities. Access to the Rocas Atoll needs prior approval by the Instituto Chico Mendes de Conservação da Biodiversidade (ICMBio), the Brazilian agency responsible for managing the federal protected areas. ICMBio led the expeditions to Rocas which is made from a sailboat departing from Natal Harbour, $500 \mathrm{~km}$ away. There are only about 12 expeditions to Rocas in a year, with around 30 days each.

Rocas is one of the smaller and shallow lagoon atolls in the world (Figure 1.2). The small-sized reef rim has an elliptical shape, a length and width of $3.5 \mathrm{~km}$ and $2.5 \mathrm{~km}$, respectively, and a west-east orientation, built by encrusting coralline red algae, vermetid gastropods, and encrusting foraminiferans (Gherardi and Bosence, 2001; Kikuchi and Leão, 1997). The main reef framework builder is the coralline algal genus Porolithon cf. pachydermum which occurs associated with four other coralline algae: Popolithon sp.; Lithophyllum sp.; Lithoporella sp.; and Sporolithon sp. (Gherardi and Bosence, 1999). Corals are located in pools of water that remain deep enough over a tidal cycle (Ferreira et al., 2012) and there is no evidence of the their joint activity with coralline algae as constructors of the reef (Gherardi and Bosence, 2001). The dominant genus is the head coral Siderastrea (Gherardi, 1995). An $11.6 \mathrm{~m}$ long drill core on the western part of the reef, with the recovery rate of $40 \%$ shows that the reef growth began before $4.8 \mathrm{ky}$ BP with the accretion rate varying from 1.5 to $3.2 \mathrm{~m} / \mathrm{ky}$ (Kikuchi and Leão, 1997). Subaerialy exposed old reef spits, elevated above tidal range, and a beachrock cliff are evidences of an equal to or higher than present sea level in Rocas, earlier in the Holocene (Kikuchi and Leão, 1997).

Rocas contains two vegetated reef islands (Farol and Cemitério) located on leeward reef rim (western side) and one unvegetated shingle bank (Zulu) on the windward reef rim (eastern side). Farol is the largest one with $674 \mathrm{~m}$ in length and $327 \mathrm{~m}$ in width. Cemitério is $380 \mathrm{~m}$ in length and $186 \mathrm{~m}$ in width and Zulu is $288 \mathrm{~m}$ in length and $144 \mathrm{~m}$ in width (Pereira, 2011). A large sand apron occupies almost half of the lagoon and becomes emergent during low tides. Their sediments are composed entirely of carbonate skeleton derived from the reef structure (Pereira et al., 2013). Sediment composition is dominated by coralline algae (61\% - 74\%), foraminifera ( $11 \%-18 \%)$ and 
molluscs (10\% - 13\%) (Soares et al., 2009b). Coral and other components comprising subordinate fractions (<10\%) (Soares et al., 2009b). The reef islands are composed predominantly by coarse sand, the shingle bank by gravel and the sand apron by medium sand (Pereira et al., 2013). The vegetation of the islands is mostly herbaceous, and consists chiefly of Portulaca oleracea (Portulacaceae), Cyperus ligularis (Cyperaceae) and Iresine portulacoides (Amaranthaceae). On Cemitério Island the vegetation is composed almost exclusively of C. ligularis (Hazin and Macedo, 2006).

Despite the small size of the reef islands, they contain an abundant fauna of visiting or nesting birds. The islands shelter the largest breeding colonies of masked booby Sula dactylatra and brown noddy Anous stolidus in Brazil and of sooty tern Sterna fuscata for the South Atlantic (Schulz-Neto, 2004). It is also the second largest Chelonia mydas rookery in Brazil (Bellini et al., 1996) and an important place for the protection of a endemic specie of land crab (Johngarthia lagostoma) which only occurs on three other South Atlantic islands (Trindade, Fernando de Noronha and Ascension) (Godley et al., 2009).

The lagoon is a nearly closed water body connected to the open ocean through two passages in the north and northwest margins on the leeward side. At low tides the lagoon becomes partially dry exposing a large sand apron. Maximum depth is of about $7 \mathrm{~m}$ during high spring tides. The north passage (larger passage; locally named Barretão) is permanently connected to the shallow lagoon, has a mean depth of $5 \mathrm{~m}$ and is $330 \mathrm{~m}$ wide. The northwest passage (smaller passage; locally named Barretinha) is located between the two reef islands and is disconnected from the lagoon by an exposed sand bank during low tides. It has a mean depth of $3 \mathrm{~m}$ and a width of $30 \mathrm{~m}$.

To date, there are no long-term tidal time series for the Rocas atoll, however, tide charts provided by the Brazilian Navy for the nearby island of Fernando de Noronha, $145 \mathrm{~km}$ to the east, show a semi-diurnal regime with an ocean tidal range of $2.8 \mathrm{~m}$ during spring tides and $1.7 \mathrm{~m}$ during neap tides. The tidal range ensures that the whole reef rim is exposed and at low tides it is $2 \mathrm{~m}$ above the ocean sea level on the windward side. The atoll is dominated by the southeast trade winds, which prevail for 93\% of the year (BDC, 2015), varying in strength according to the Intertropical Convergence Zone (ITCZ) seasonality (McGregor and Nieuwolt, 1998). Average wind speed is approximately $5 \mathrm{~m} . \mathrm{s}^{-1}$ with maximum speed around $11 \mathrm{~m} . \mathrm{s}^{-1}$ (BDC, 2015). As a result, wind waves generated by these local winds dominate the wave field at Rocas and break on the windward reef crest most of the year (Chapter 2). Due to its location near the equator, North and South swells also contribute to the wave conditions at Rocas, and they are generated during both hemisphere winters (Chapter 2 ).

Rocas also lies within the South Equatorial Current (SEC), which has a mean velocity of $30 \mathrm{~cm} . \mathrm{s}^{-1}$, and the seasonal variation of velocity around this annual mean is $10 \mathrm{~cm} . \mathrm{s}^{-1}$ 
(Richardson and Walsh, 1986). Monthly mean sea surface temperature varies from 26 ${ }^{\circ} \mathrm{C}$ in September to $28.3{ }^{\circ} \mathrm{C}$ in April, with peak annual temperatures in March-AprilMay (Ferreira et al., 2012). Month average rainfall varies between $6 \mathrm{~mm}$ (October) and $132 \mathrm{~mm}$ (April), with annual average of $700 \mathrm{~mm}$ (BDC, 2015).

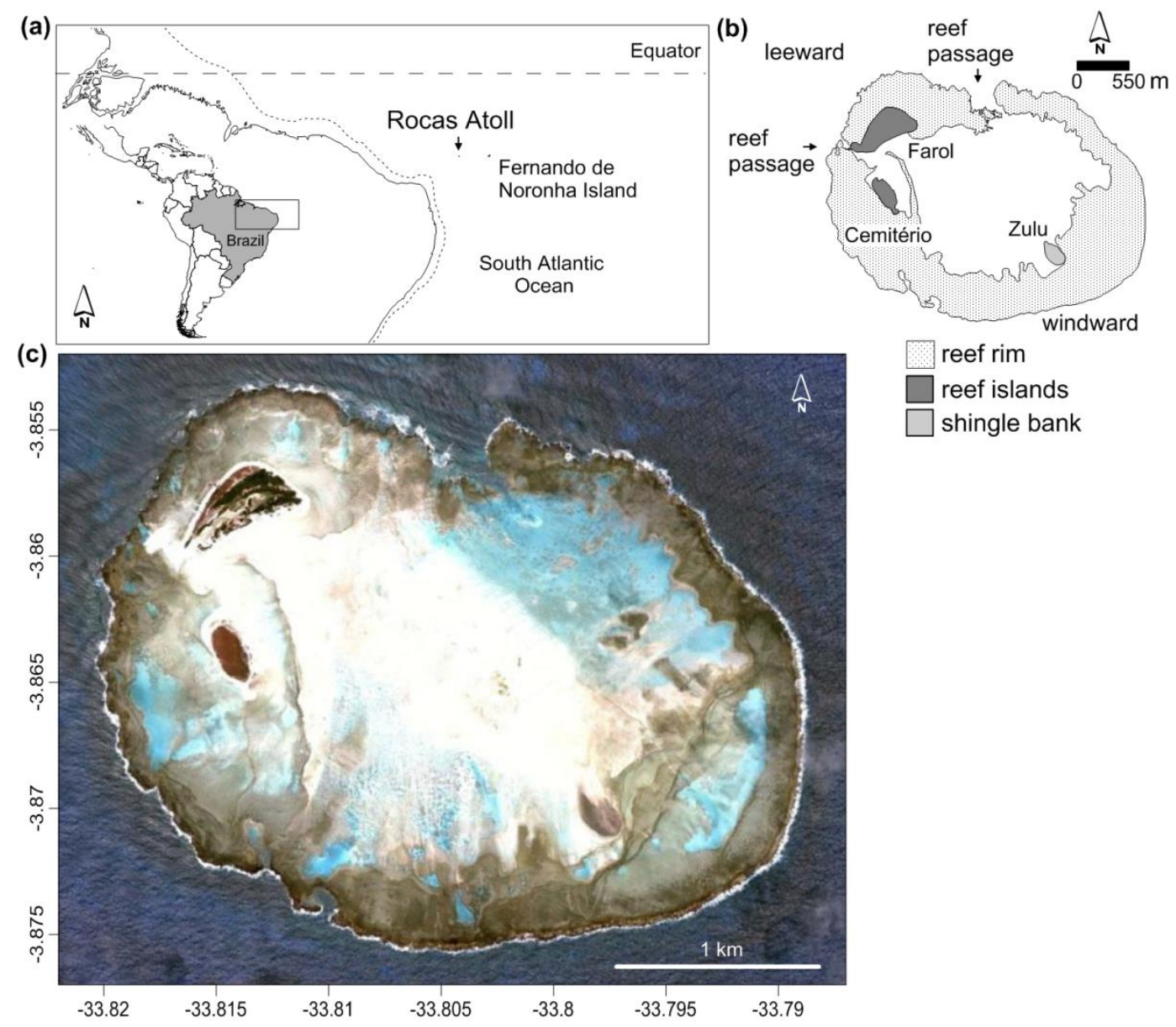

Figure 1.1. Rocas Atoll. 

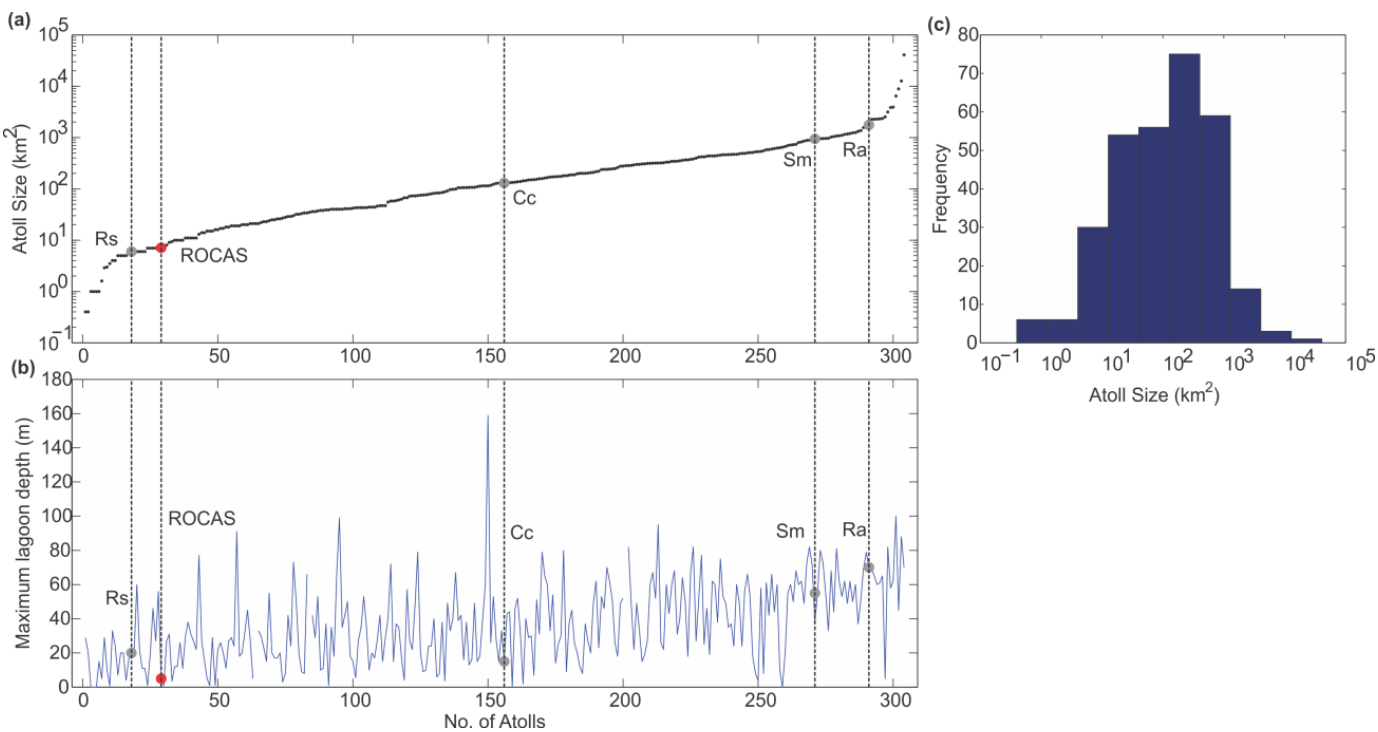

Figure 1.2. Distribution 304 atolls (a) sizes and (b) their maximum lagoon depths from Pacific, Indian and Atlantic Oceans. Rocas atoll is highlighted by a red dot on the graphs. For comparative purposes, letters on gray dots refers to Rose Atoll (Rs) and Rangiroa Atoll, Tuamotu (Ra) both on Pacific Ocean, Cocos-Keeling Atoll (Cc) and South Maalhosmadulu Atoll, Maldives $(\mathrm{Sm})$ both on Indian Ocean. (c) Histogram showing the size frequency distribution. Database from GSA Data Repository item 2001075 available online at ftp://rock.geosociety.org/pub/reposit/2001/2001075.pdf.

\subsection{Thesis layout}

This thesis presents results of a series of field experiments and numerical modeling in the form of four main chapters, written in the form of manuscripts submitted or to be submitted to journals. Following the introduction (Chapter 1), the general themes of each chapter correspond to the specific objectives of this thesis: wave climate (Chapter 2); wave and tidal induced currents (Chapter 3); morphodynamics of the reef islands (Chapter 4); and effects of sea level rise on wave propagation and its implication for the reef islands geomorphology (Chapter 5). Finally, in Chapter 6, concluding remarks from each of the four main chapters are summarized and suggestions of future works is presented. Photographs taken during field expeditions are shown in the APPENDIX. 


\section{Chapter 2}

\section{WAVE CLIMATE AND EXTREMES ON ROCAS ATOLL}

\subsection{Introduction}

Geomorphic and ecological processes on atolls and coral reef lagoons are closely linked to local wave and tide climates (Woodroffe and Biribo, 2011). As open-ocean waves approach a reef and breaks they generates a rise in the dynamic sea level relative to the offshore mean sea level initiating water transport across the rim towards the lagoon (Atkinson et al., 1981; Kraines et al., 1999; Lowe and Falter, 2015; Tartinville et al., 1997). The directions of these wave-induced currents will depend on the swell and wind wave direction. The side facing the largest waves will have large amounts of water pushed over the reef rim while water will drain to the ocean on the leeward side, and this process is modulated by tides (Callaghan et al., 2006).

The combination of tide and wave-driven flows through the rim are critical for ecological functioning of reef systems such as renewal of water and oxygen and their uptake by corals (Hearn et al., 2001; Jokiel, 1978; Nakamori et al., 1992), removal of metabolic wastes and flushing of reef lagoons (Dumas et al., 2012; Frith and Mason, 1986; Kench, 1998a) and, the dispersal and recruitment of larvae (Abelson and Denny, 1997; Black, 1993; Hamner and Wolanski, 1988)

However, depending on the local tidal setting, not all wave energy will be dissipated at the reef edge at high tide (Kench et al., 2006). Instead, waves may propagate onto the reef surface either as transformed incident waves, reformed waves, or wave bores (Lugo-Fernández et al., 1998a; Nelson, 1996). The wave energy that leaks onto coral reef surfaces is of critical importance in activating the geomorphic processes of sediment transport and governing reef island construction and morphological change (Brander et al., 2004; Gourlay, 1988; Kench, 1998b; Roberts et al., 1992).

Large scale numerical hindcast modelling has provided continuous time series of offshore wave parameters over significant periods of time (Chini et al., 2010), allowing the consistent description of the wave climate and extreme wave analysis in locations where instrumental data are unavailable (Camus et al., 2013). These types of models have been used to define the wave climate and extremes under offshore conditions; however, waves are poorly described at shallow water areas because the spatial resolution is not sufficiently detailed and because wave transformations, due to the interaction with the complex bathymetry, are not typically modeled (Camus et al., 2013). 
Downscaling is the method to obtain wave climate information at high spatial resolution from relatively coarse resolution (Camus et al., 2011). The implementation of high-resolution wave models can be used to downscale the historical wave climate from hindcast models and reconstruct the spatial wave fields in shallow water, where depth variations and local bathymetry are important variables for wave transformation.

Specifically in atolls, the characteristics of waves that propagate into the lagoon may be very different from the conditions observed offshore due to wave transformation and interaction with the reef. The tide plays a key role in this process, controlling the water level above the reef and modulating the amount of energy that can be transmitted by the atoll rim. Thus, the definition of extreme conditions inside the lagoon may be directly related not only to the extreme conditions of offshore waves but also, and especially, to the joint occurrence with spring tides.

Through the reconstruction of lagoon long-term time series by downscaling offshore historical wave climate, this study aims to assess the wave climate and wave extremes analysis on a mesotidal atoll lagoon (Rocas Atoll); this step involves the implementation and validation of a high-resolution numerical wave model. Moreover, this study addresses the joint recurrence of energetic wave conditions and high tides and the implications of the differences on the offshore and lagoon wave climates to geomorphological process inside the atoll.

\subsection{Methods}

The wave climate was characterized using data from available global models and applying a local wave propagation model. The strategy consisted in statistically analyzing the wave characteristics time series available in global models to represent the incident wave climate for the atoll (offshore) and to reconstruct this series through a local model to represent the waves inside the atoll (lagoon), considering the transformations in their propagation through the shallow parts of the atoll and the tidal effect (Figure 2.1). 


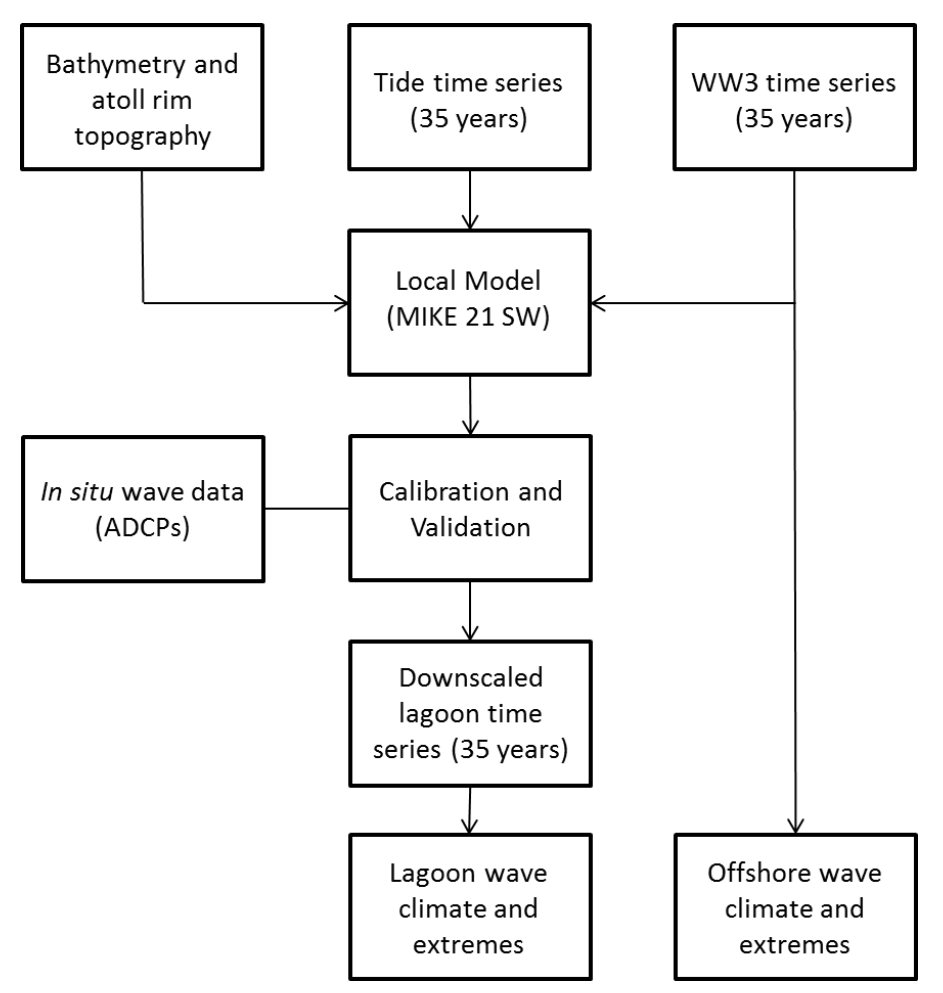

Figure 2.1. Global framework to obtain offshore and lagoon wave databases.

\subsubsection{Global model}

The wave climate analysis of Rocas Atoll was performed using data from the global wave generation model WAVEWATCH III (NWW3) version 2.2, developed by the National Oceanic and Atmospheric Administration/National Centers for Environmental Prediction (NOAA/NCEP; Tolman 2002), which uses the wind fields produced by the global atmospheric model Global Forecast System (GFS) as forcings. The model solves the wave action spectral density conservation equation to generate global domain spectral and wave characteristics data. The data are available at $3 \mathrm{~h}$ intervals with 0.5 degree spatial resolution, except in regions at latitudes above $78^{\circ}$, where the surface becomes predominantly solid in both hemispheres (ice or continent). The Climate Forecast System Reanalysis and Reforecast (CFSRR) dataset (Springs et al., 2010), whose period extends from 1979 to 2009, generating a total of 35 years (from 1979 to 2014) of data collected for the grid nearest the Rocas Atoll, and the historical dataset from 2005 to 2014 were used to enable greater temporal coverage.

\subsubsection{Local model}

To evaluate the wave climate for Rocas lagoon with high temporal and spatial resolution, the offshore wave data from NWW3 were downscaled using the MIKE21 SW model. MIKE21 SW represents a third-generation spectral wave model that solves the wave action conservation equation using a parameterization of the zeroth and first-order moments of the wave action spectrum in the frequency domain (Holthuijsen et al., 1989). The model estimated the transformation of incident wave 
energy by shoaling, refraction, diffraction, and dissipation by both depth-induced wave breaking and bottom friction. Wind forcing can be included in the model, but it has been ignored in the present work. The domain and the governing equations are discretized using the finite volume method. The model is quasi-stationary using a Runge-Kutta iterative procedure to compute the stationary wave field at each time step. A detailed description of the model can be found in Sørensen et al. (2004).

A constant breaker coefficient $\gamma=0.8$ was used to parameterize the wave breakinginduced dissipation. The gamma value controls the wave steepness conditions, wherein a threshold ratio is reached before the break, considering the local depth. Its formulation is reported in (Battjes and Janssen, 1978). Wave dissipation due to bottom friction was based on the formulation by (Madsen et al., 1988), using a constant Nikuradse bed roughness length of $\mathrm{Kn}=0.04 \mathrm{~m}$. This value is equivalent to a friction factors ( $\mathrm{fw}$ ) of 0.1 for smooth healthy coral reefs (Sheppard et al., 2005). The friction coefficient was held constant over the entire domain, but in practice, friction is only a significant factor for shallower reef flat regions (Baldock et al., 2014).

An unstructured mesh containing 6953 triangular elements was prepared with 3 different resolutions to solve the differences in the bathymetric scale along the model domain (Figure 2.2). A fine grid with approximately $60 \mathrm{~m}$ spatial resolution was defined inside connected to the lower offshore resolution of approximately $1.5 \mathrm{~km}$ by an intermediate resolution grid with cells of approximately $600 \mathrm{~m}$. The long-term time series from the global model NWW3 was applied to the lateral wave boundary of the outer grid; thus, wave transformations over the submerged mountain of which Rocas Atoll is located could be estimated before being passed to the finer portion of the grid.

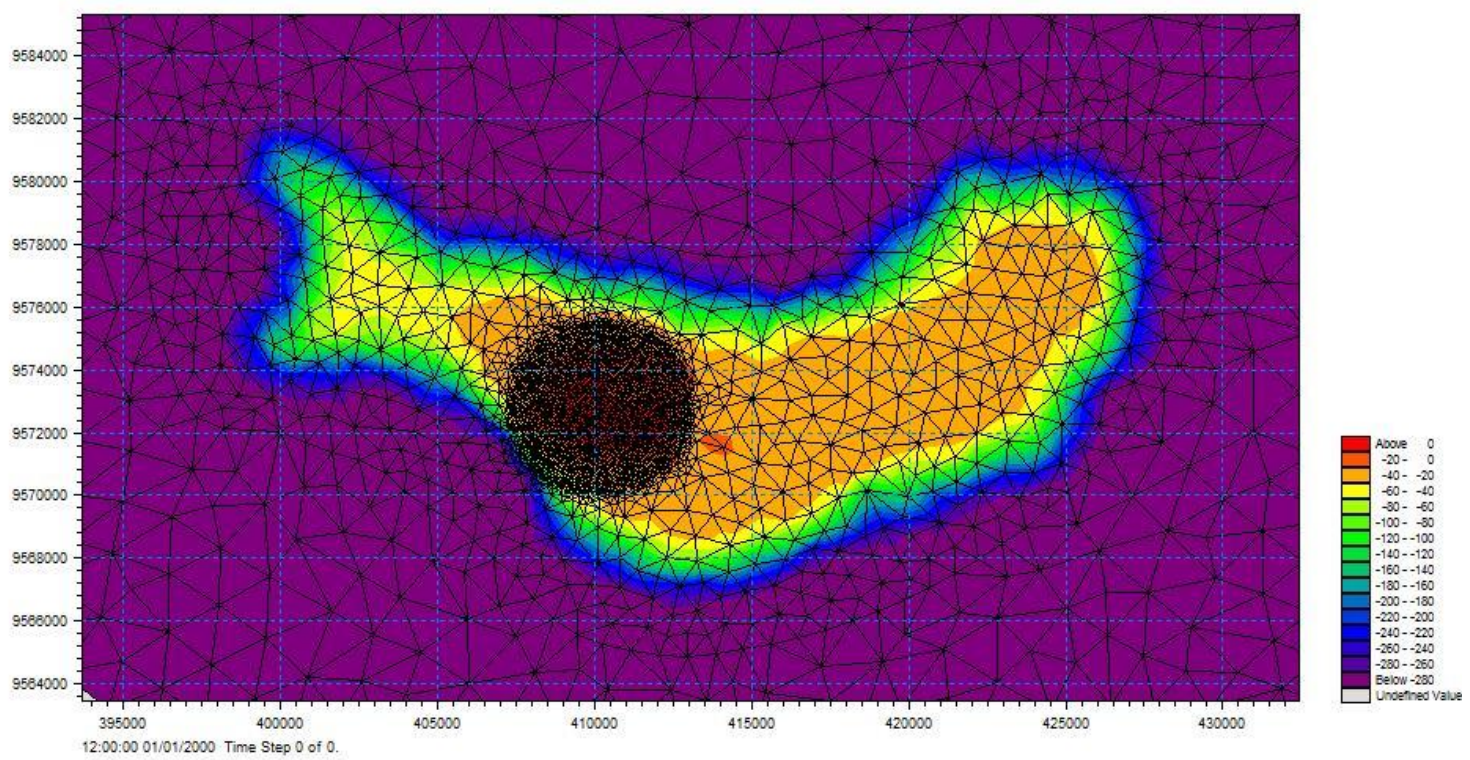

Figure 2.2. Computational mesh resolution of the domain modeled.Computational mesh resolution of the domain modeled. 
To represent the complex topography of the atoll used at the finer grid, topographic and bathymetric surveys were conducted using a Trimble dual-frequency kinematic Global Position System (GPS) coupled with a Garmin echosounder and installed in a monohull vessel. The measurements were done along equally spaced profiles (100 $\mathrm{m}$ ) across the lagoon. At dry section of the atoll, such as the reef rim and the reef islands, surveys were conducted by foot during low tides using the rover GPS unit mounted in a backpack kit. The data were tidally corrected and processed by a post-kinematic technic using the TBC software. Details on the acquisition of the topography and bathymetry can be found in Chapter 5 . The bathymetry used in the intermediate and coarse grid (offshore waters) was gathered from Brazilian Navy nautical charts 5101 and 5102 (Figure 2.3). The datum of both sources (in situ survey and nautical charts) was adjusted to the Rocas Atoll hydrographic zero.

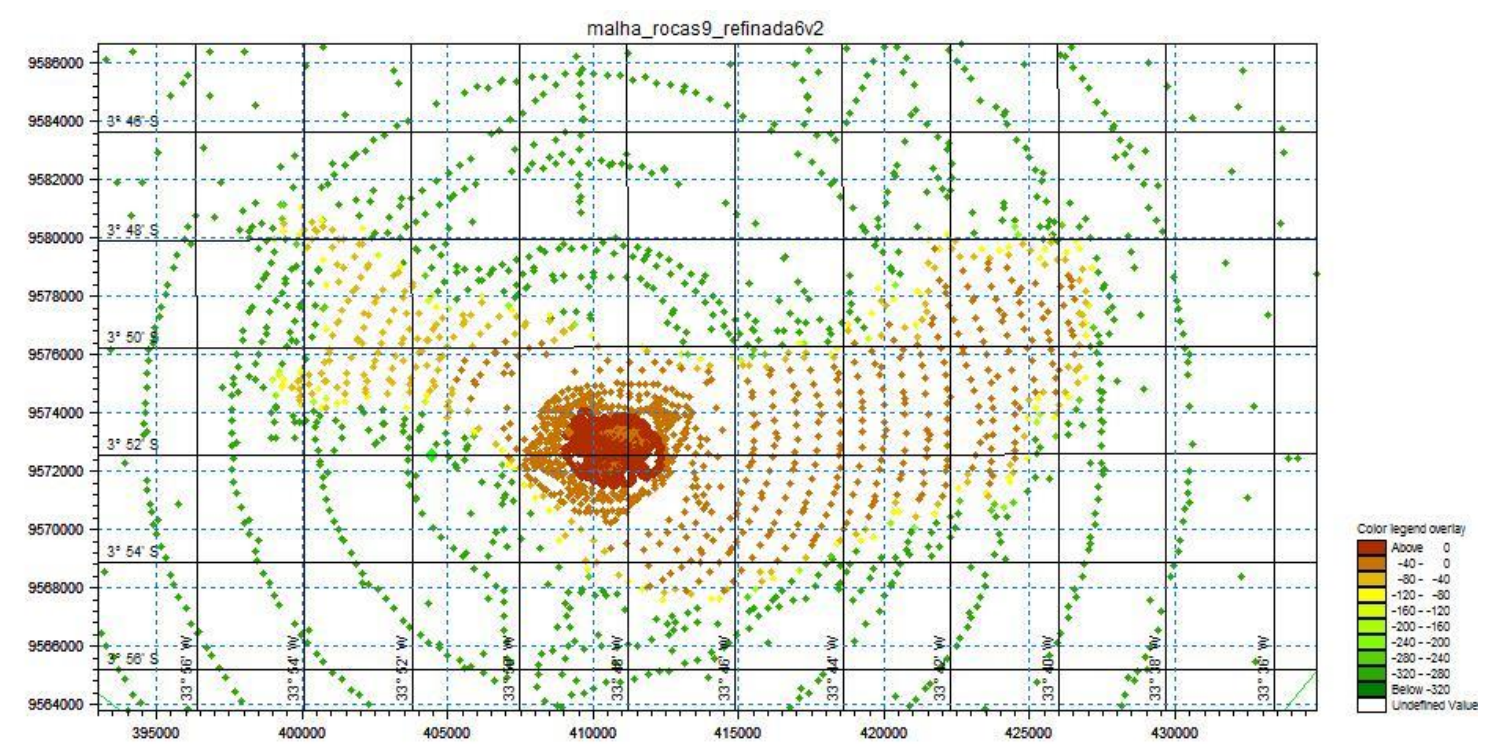

Figure 2.3. Bathymetric resolution used in the domain modeled.

The tidal variation time series for the analysis period (from 1979 to 2014) was used as the model input to reconstruct the wave climate inside the lagoon. This time series was reproduced using the tidal harmonic constants extracted from in situ data on the sea level variation collected at Fernando de Noronha Archipelago, encompassing 611 sampling days with $60 \mathrm{~min}$ intervals, totaling 14,664 heights recorded. Those data were provided by the National Bank of Oceanographic Data of the Brazilian Navy (Banco Nacional de Dados Oceanográficos da Marinha do Brasil).

\subsubsection{Definition of wave climate and extremes}

The lagoon and offshore wave climate of Rocas Atoll was defined by analyzing the seasonality and extremes events based on the time series from 1980 to 2014. Directional wave climatologies were constructed by discretizing wave parameters $\mathrm{Hs}$ and $\mathrm{Tp}$ into $0.5 \mathrm{~m}$ and $2 \mathrm{~s}$, respectively, by $45^{\circ}$ peak wave direction $(\theta \mathrm{p})$ bins that 
correspond to the 8 wave direction octants (N, NE, E, SE, S, SW, W, NW). These binned values were then analyzed for the most frequent occurrences of $\mathrm{Hs}$ and $\mathrm{Tp}$ (typical conditions) and the 99th percentiles (maximum condition). This method allows for an examination of how often (in a year or season) a particular wave direction/frequency event tends to occur and its average magnitude (Hoeke et al., 2011).

Considering that the greatest heights are not necessarily associated with the longest annual periods and that the combination of both high values corresponds to the highest wave energy events, the wave force was calculated to classify the swell intensity and characterize extreme events. The wave force $(P$, expressed as $k W / m)$ correlates $\mathrm{Hs}$ and $\mathrm{Tp}$ through the product between group velocity $\left(\mathrm{C}_{\mathrm{g}}\right)$ and wave energy $(E)$, resulting in the following equation:

$$
P=\frac{\rho g^{2} H^{2} T}{32 \pi}
$$

where $\rho$ is the water density $\left(1027 \mathrm{~kg} / \mathrm{m}^{3}\right)$ and $\mathrm{g}$ is the acceleration due to gravity.

High values of both parameters ( $\mathrm{Hs}$ and $\mathrm{Tp}$ ) are associated with energetic events capable of causing significant changes in sediment morphology. This equation is used to define the swell intensity classes incidents at Rocas Atoll according to the intervals listed in Table 2.1.

Table 2.1. Wave intensity classification based on wave power.

\begin{tabular}{cc}
\hline Intensity & Wave Power $(\mathrm{kW} / \mathrm{m})$ \\
\hline Extreme & $\mathrm{P} \geq 50$ \\
Severe & $50>\mathrm{P} \geq 40$ \\
Strong & $40>\mathrm{P} \geq 30$ \\
Moderate & $30>\mathrm{P} \geq 20$ \\
Weak & $20>\mathrm{P} \geq 10$ \\
Calm & $\mathrm{P}<10$ \\
\hline
\end{tabular}

\subsection{Local model validation}

The model was validated using the time series recorded by two Acoustic Doppler Current Profilers (ADCPs) deployed for 28 days on Rocas Atoll. The significant wave height, which is considered one of the most common parameters in wave spectra validation, was used for this purpose (Abdalla et al. 2006). The ADCPs operated intermittently with a sampling frequency of $2 \mathrm{~Hz}$. The wave characteristics were measured in 2048 bursts ( $17.1 \mathrm{~min}$ ) hourly. One ADCP was deployed in the lagoon at approximately $2 \mathrm{~m}$ of depth, whereas the other was deployed outside the atoll, at approximately $16 \mathrm{~m}$ of depth (Figure 2.4). The offshore ADCP was used to assess the agreement between the NWW3 data applied as boundary conditions and the data measured in situ, before reaching the atoll, whereas the lagoon ADCP was used to 
assess the quality of the model regarding the wave transformation through the edge of the atoll and the tidal effect on this process.
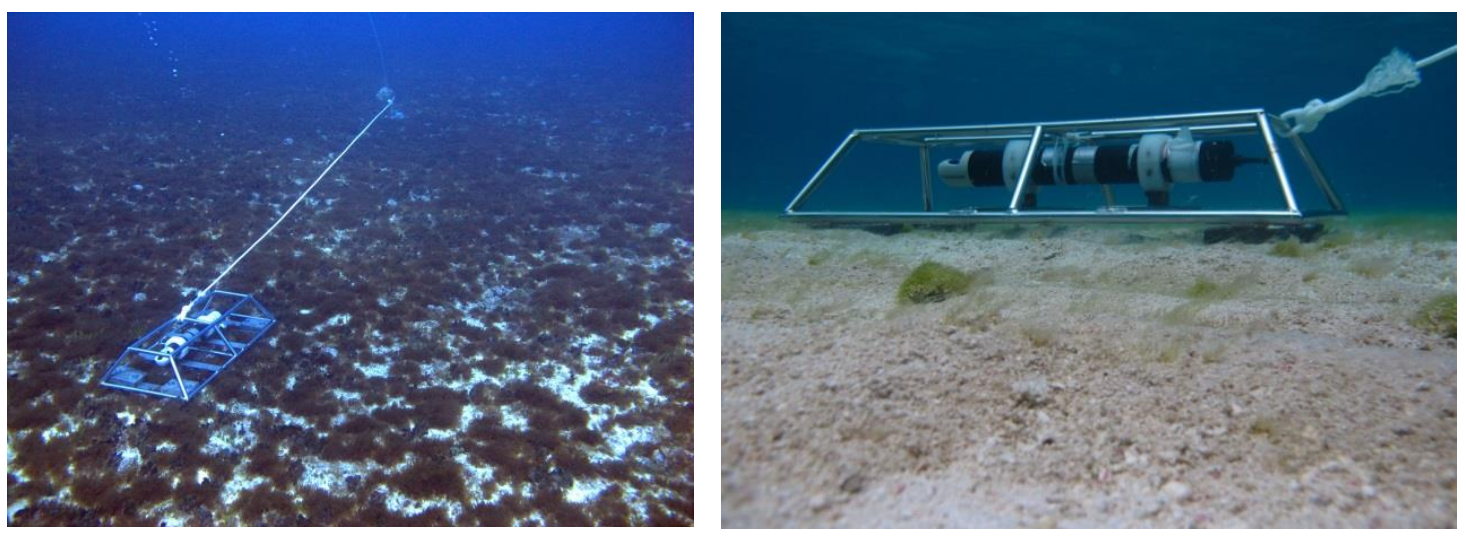

Figure 2.4. Deployment of the (a) offshore and (b) lagoon ADCPs at Rocas Atoll.

The calibration process included variations in the parameters described in the previous section (e.g., mesh resolution, wave breaking parameter, bottom friction) to find the best relationship between computational effort demand and agreement with the in situ data. The difference between the modeled significant wave height $(\mathrm{Hmo})$ and the measured significant wave height ( $\mathrm{Hme}$ ), mean difference (bias), root-mean-square error (RSME), and correlation coefficient (cc) for ADCP match points were used to verify the performance of the model.

$$
\begin{gathered}
\Delta H=H_{m o}-H_{m e} \\
\text { bias }=\frac{1}{N} \sum_{i=1}^{N} \Delta H \\
R M S E=\sqrt{\frac{1}{N} \sum_{i=1}^{N} \Delta H^{2}} \\
c c=\frac{3}{\sqrt{\sum_{i=1}^{N}\left(H_{m e}-\overline{H_{m e}}\right)\left(H_{m o}-\overline{H_{m o}}\right)}} \quad 4 \\
\left.\sqrt{i=1}-\overline{H_{m e}}\right)^{2} \sum_{i=1}^{N}\left(H_{m o}-\overline{H_{m o}}\right)^{2}
\end{gathered}
$$

The error $(\Delta \mathrm{H})$ in time, scatter diagrams, and error histogram are shown in Figure 2.5. The model well reproduced the wave conditions both offshore and inside the lagoon. The validation results indicated that the bias of the offshore and lagoon stations is $0.106 \mathrm{~m}$ and $0.027 \mathrm{~m}$, respectively, and that the RMSE is $0.327 \mathrm{~m}$ and $0.040 \mathrm{~m}$, respectively. The correlation coefficient (cc) between $\mathrm{Hmo}$ and $\mathrm{Hme}$ is 0.507 and 0.964 , respectively. The values indicate better model performance in the lagoon. 
The comparison between the measure and modeled time series is show in Figure 2.6. The process of tidal modulation of waves inside the lagoon is observed, with greater heights at high tide and smaller heights at low tide, and this process is well resolved by the model. Figure 2.5 and Figure 2.6 draw attention to a specific event that was not reproduced by the model in the offshore station using NWW3 data as the input, generating a $1.65 \mathrm{~m}$ difference between the modeled and measured waves. However, this event had no effect on the quality of the wave height modeled in the lagoon because this difference was only $-0.002 \mathrm{~m}$. Thus, short variations in offshore wave height are not significant in relation to the expected wave height inside the lagoon, considering that the tide is the main factor controlling the energy level of the incident wave to be propagated into the atoll, which explains why the model reproduced the wave characteristics inside the lagoon more accurately.
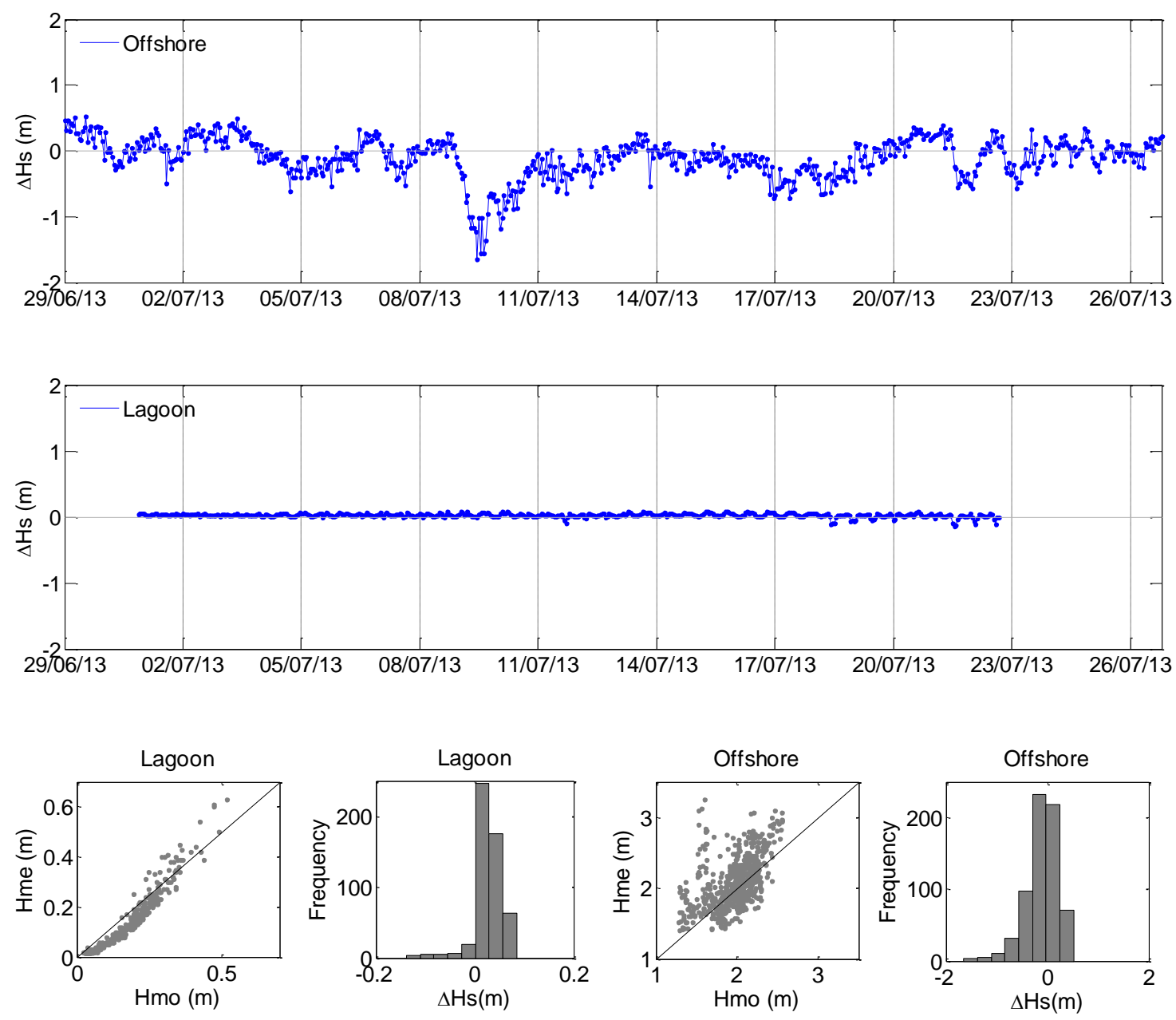

Figure 2.5. Time series of the difference of the modeled (Hmo) and measured (Hme) significant wave height at (a) offshore and (b) lagoon station. Model accuracy statistics: (c,e) histogram of model error and (b,f) scatter diagram of modeled ( $\mathrm{Hmo}$ ) and measured (Hme) significant wave height for offshore and lagoon station. 

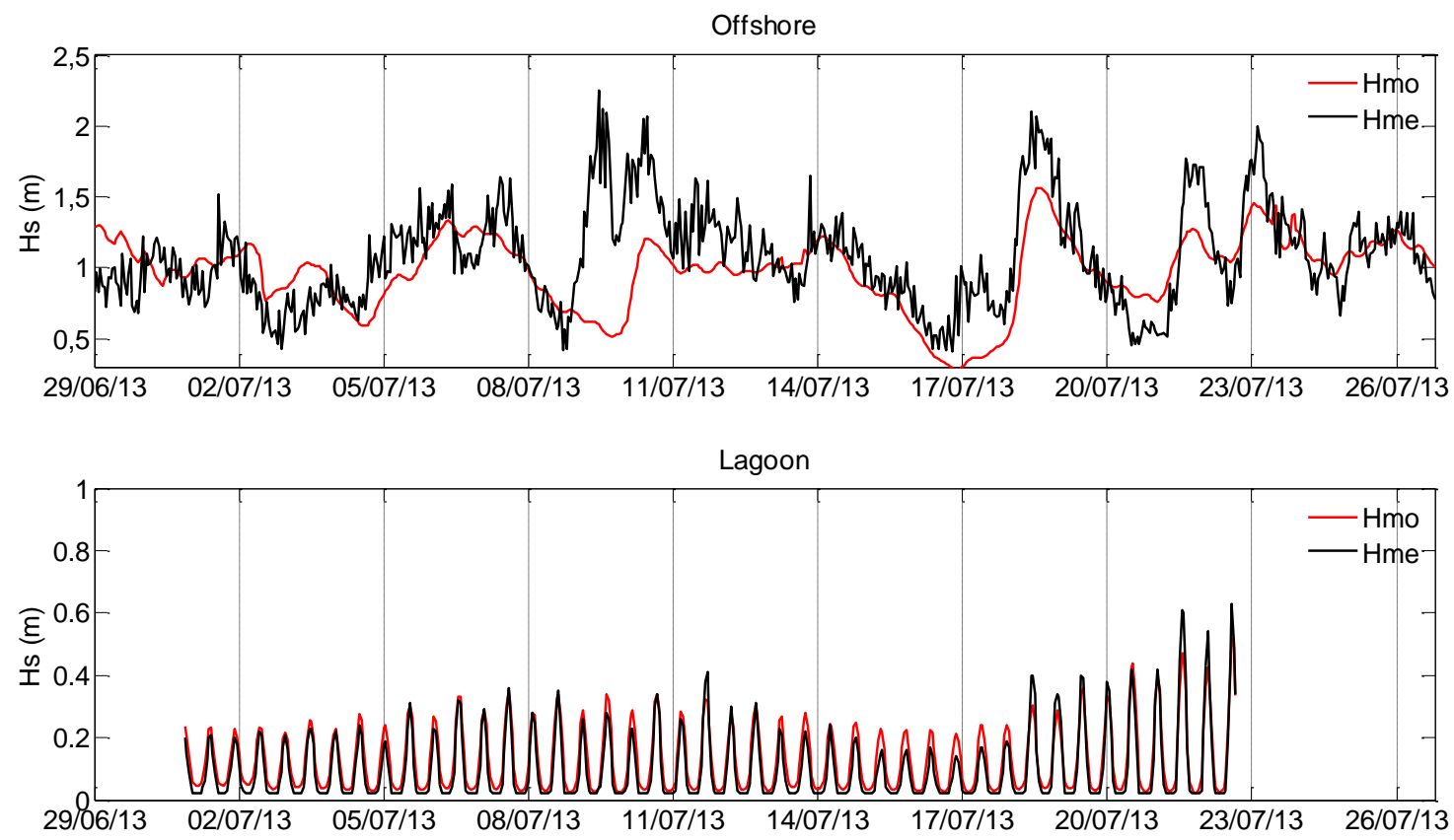

Figure 2.6. Time series of the measured ( $\mathrm{Hme}$ ) and modeled $(\mathrm{Hmo})$ significant wave height used for validation at the (a) offshore and (b) lagoon station.

A more detailed analysis of the time error in the lagoon indicates that the main differences between the measured and modeled data occurred as a result of the relationship between the level of energy dissipation and depth (Figure 2.7). Changing the friction parameter of the model is only possible by varying the field and keeping it constant in time. However, the greatest errors occurred at high tide, and the attenuation of modeled data should be greater during neap tide and smaller during spring tide. This finding agrees with the dynamic change of bottom friction due to the changing water level and tidal currents suggested by Arora \& Bhaskaran (2012) for tidal dominated regions. The general trend is that the friction coefficient has higher values during less energetic neap tides and lower values during more energetic spring tides (Jarosz et al., 2005). Furthermore, when the mean tidal velocity has higher energy, e.g., during spring tides, the roughness length is lower, and during neap tides, when tidal energies are reduced, the roughness length increases. They address a new resistance law for bottom friction under the combined action of waves and currents that takes into account varying water levels, the reversal of the current system, and associated shear on the seabed. This formulation may improve the accuracy of the model for the region. However, the data modeled for the lagoon are highly satisfactory for the purpose of the present study. 


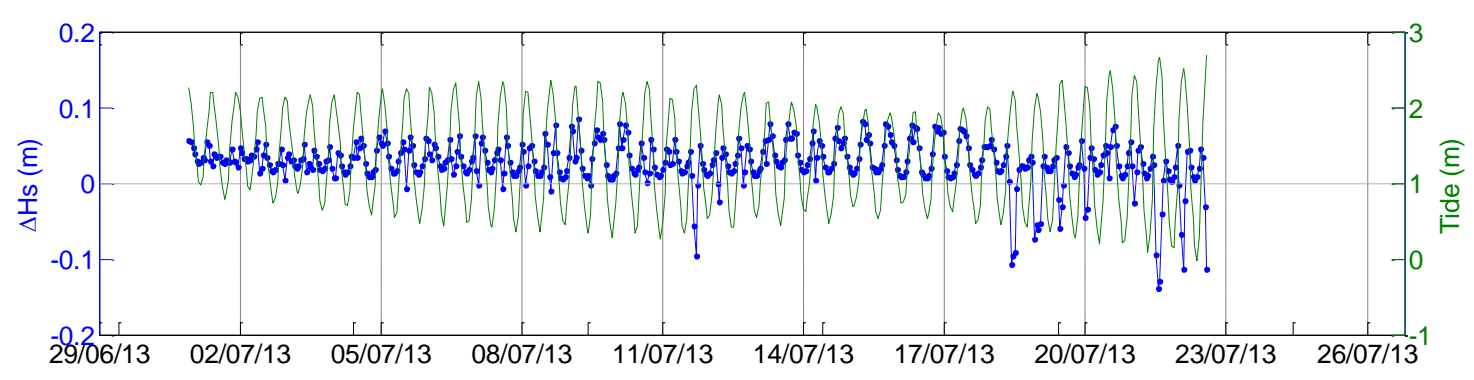

Figure 2.7. Time series of the difference of the modeled (Hmo) and measured (Hme) significant wave height plot against tide at lagoon station.

\subsection{Results}

After implementing and validating the model, the wave climate series inside the lagoon was reconstructed. The results shown below correspond to the analysis of 2 data series of 35 years each, including 1 series directly extracted from the global model NWW3 that represents the offshore wave climate and another series reconstructed using the local model MIKE 21 SW that represents the lagoon wave climate. The first data year was extracted from both time series because it has spurious values. The offshore series had a total of 102,271 data points for each characteristic, with a $3 \mathrm{~h}$ interval, whereas the lagoon series had a total of 306,813 data points for each characteristic, considering that the output interval of the global model was $1 \mathrm{~h}$.

\subsubsection{Typical conditions}

The typical and extreme conditions are shown using classes of wave occurrence values and plotting the results in 2-dimensional histograms (Figure 2.8). In addition, Table 2.2 outlines the percentage values of the class that represents the mode of the Tp and Hs distribution, which is used to characterize the typical pattern, and the values that occur above the $99 \%$ percentile, which are used to characterize the extreme values. 

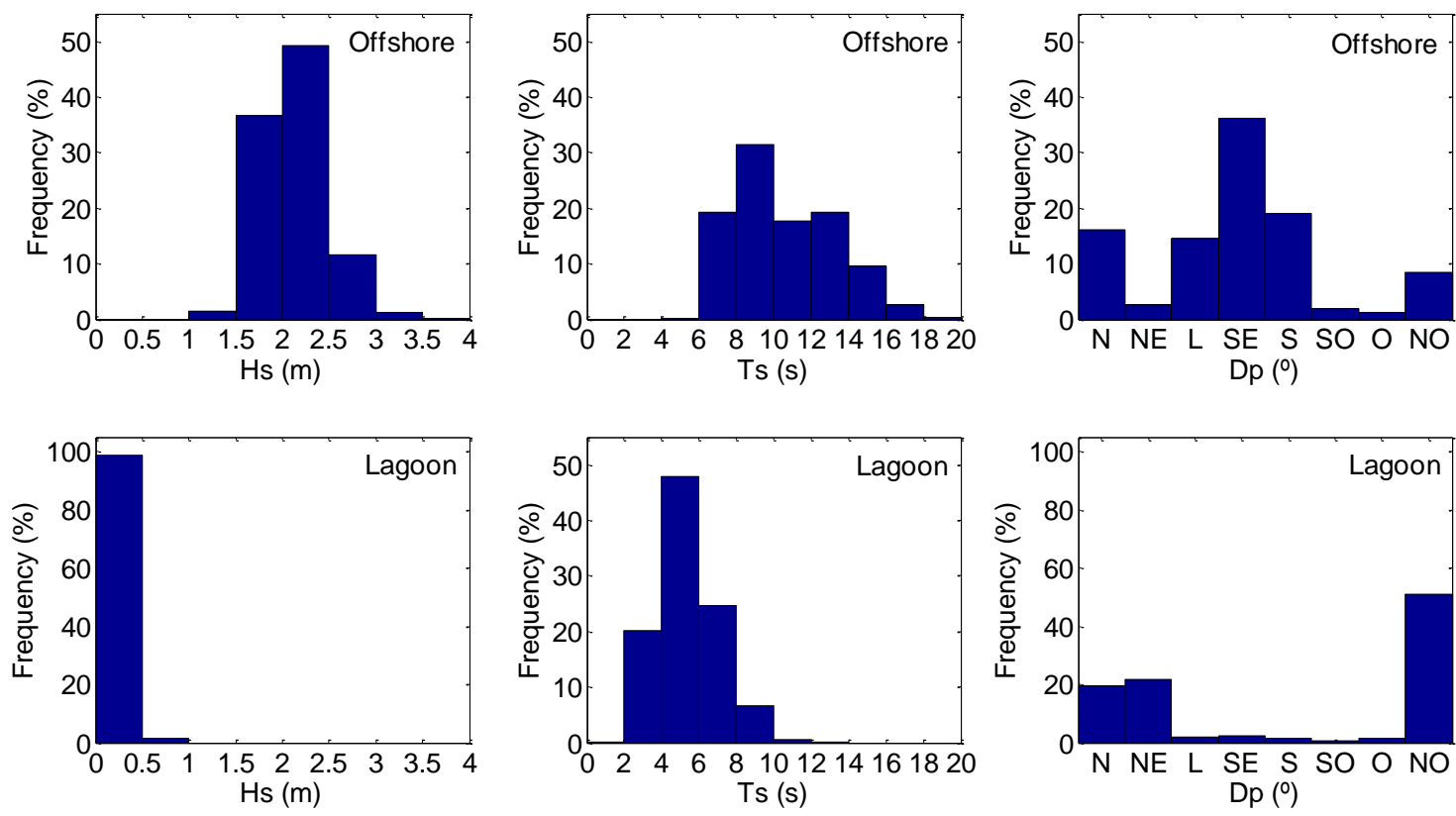

Figure 2.8. Histograms of $(a, d)$ significant wave height, $(b, e)$ peak period and $(c, f)$ peak direction in the Rocas Atoll lagoon and offshore between 1980 and 2014.

Table 2.2. Typical and extreme values of significant wave height and peak period for Rocas Atoll.

Significant wave height

Peak wave period

\begin{tabular}{|c|c|c|c|c|c|}
\hline Pattern & Class & Range (m) & Percentual (\%) & Range (s) & Percentual (\%) \\
\hline \multicolumn{6}{|c|}{ Offshore } \\
\hline Typical & Modal class & $2,0-2,5$ & 49,2 & $8,0-10,0$ & 31,4 \\
\hline Extreme & Percentil 99\% & $3,04-3,93$ & 1 & $17,24-21,79$ & 1 \\
\hline \multicolumn{6}{|c|}{ Lagoon } \\
\hline Typical & Modal class & $0,0-0,5$ & 98,6 & $4,0-6,0$ & 47,9 \\
\hline Extreme & Percentil 99\% & $0,52-0,81$ & 1 & $9,72-13,32$ & 1 \\
\hline
\end{tabular}

The significant offshore wave heights ranged from $1.09 \mathrm{~m}$ to $3.93 \mathrm{~m}$, averaging $2.12 \mathrm{~m}$. Significant wave heights between $2.0 \mathrm{~m}$ and $2.5 \mathrm{~m}$ were predominant, at $49.2 \%$ frequency of occurrence, followed by heights between $1.5 \mathrm{~m}$ and $2.0 \mathrm{~m}$, at a frequency of $36.6 \%$. Peak periods had a distribution between $5.20 \mathrm{~s}$ and $21.79 \mathrm{~s}$, with a mean of $10.54 \mathrm{~s}$. Periods between $8 \mathrm{~s}$ and $10 \mathrm{~s}$ occurred in $31.4 \%$ of all records and between $6 \mathrm{~s}$ and $8 \mathrm{~s}$ in $19.3 \%$. Most waves came from the SE (36.1\%), followed by the $\mathrm{S}$ and $\mathrm{N}$ octants, with $19.0 \%$ and $16.1 \%$ each, respectively, and by the $E$ and NW octants, with $14.4 \%$ and $8.5 \%$, respectively. The remaining octants had a frequency of lower than $3 \%$ of all occurrences (Figure 2.8). For the extreme pattern, the $99 \%$ percentile covered an Hs range between $3.04 \mathrm{~m}$ and $3.93 \mathrm{~m}$ and a Tp range from $17.24 \mathrm{~s}$ to $21.79 \mathrm{~s}$ (Table 2.1).

The significant lagoon wave heights ranged from $0.01 \mathrm{~m}$ to $0.81 \mathrm{~m}$, averaging $0.16 \mathrm{~m}$. Significant heights between $0 \mathrm{~m}$ and $0.5 \mathrm{~m}$ corresponded to $98.6 \%$ of the occurrences 
in the lagoon, followed by $1.3 \%$ for the class between 0.5 and $1.0 \mathrm{~m}$. Peak periods had a distribution between $1.81 \mathrm{~s}$ and $13.32 \mathrm{~s}$, with a mean of $5.37 \mathrm{~s}$. Periods between $4 \mathrm{~s}$ and $6 \mathrm{~s}$ occurred in $47.9 \%$ of all records and between $6 \mathrm{~s}$ and $8 \mathrm{~s}$ in $24.7 \%$. Most waves came from the NW (51.2\%), followed by the NE and N octants, with $21.6 \%$ and $19.8 \%$ each, respectively. The other octants had a frequency of lower than $3 \%$ of all occurrences (Figure 2.8). For the extreme pattern in the lagoon, the $99 \%$ percentile covered an Hs range between $0.52 \mathrm{~m}$ and $0.81 \mathrm{~m}$ and a Tp range from $9.72 \mathrm{~s}$ to $13.32 \mathrm{~s}$ (Table 2.2).

\subsubsection{Directional wave climatologies}

Figure 2.9 shows the directional histograms of the joint distribution of Hs and Tp by directional sector (Dp). The typical offshore SE direction is associated with an Hs and Tp ranging from $2.0 \mathrm{~m}$ to $2.5 \mathrm{~m}$ (51.7\%) and from $8 \mathrm{~s}$ to $10 \mathrm{~s}(21.9 \%)$, respectively. In this directional sector, the extreme values range from $3.12 \mathrm{~m}$ to $3.86 \mathrm{~m} \mathrm{(1 \% )} \mathrm{and} \mathrm{from}$ $12.59 \mathrm{~s}$ to $18.02 \mathrm{~s}(1 \%)$. The $\mathrm{S}, \mathrm{N}$, and NW directions are typically associated with waves with longer periods, ranging from $12 \mathrm{~s}$ to $14 \mathrm{~s}(39.8 \%, 34.3 \%$, and $48.2 \%$, respectively), with heights ranging from $2.0 \mathrm{~m}$ to $2.5 \mathrm{~m}$ (50.4\%, 49.2\%, and $46.1 \%$, respectively). The extreme values range from $3.09 \mathrm{~m}$ to $3.66 \mathrm{~m} \mathrm{(1 \% )}$ and $17.65 \mathrm{~s}$ to $20.72 \mathrm{~s}(1 \%)$ for the $\mathrm{S}$ sector, from $2.85 \mathrm{~m}$ to $3.93 \mathrm{~m} \mathrm{(1 \% )}$ and $17.65 \mathrm{~s}$ to $21.23 \mathrm{~s} \mathrm{(1 \% )} \mathrm{for} \mathrm{the} \mathrm{N}$ sector, and from $2.84 \mathrm{~m}$ to $3.50 \mathrm{~m} \mathrm{(1 \% )}$ and $17.68 \mathrm{~s}$ to $21.79 \mathrm{~s}(1 \%)$ for the NW sector. The $\mathrm{E}$ quadrant is associated with waves with shorter periods, ranging from $6 \mathrm{~s}$ to $8 \mathrm{~s}$ (56.5\%), typical Hs from $1.5 \mathrm{~m}$ to $2.0 \mathrm{~m}$ (47.2\%), and extreme values ranging from 2.74 $\mathrm{m}$ to $3.14 \mathrm{~m}(1 \%)$ and $11.29 \mathrm{~s}$ to $14.39 \mathrm{~s}(1 \%)$.

Throughout the period of analysis, the N, NW, and NE waves with periods longer than $12 \mathrm{~s}$ had $23.59 \%$ of occurrence, whereas the S, SW, and SE waves with periods longer than $12 \mathrm{~s}$ had $23.95 \%$. The remainder (52.46\%) consisted of waves with periods shorter than $12 \mathrm{~s}$ of various directions, but mainly SE and $\mathrm{E}$.

In the lagoon, all directions were preferentially associated with the Hs class from $0 \mathrm{~m}$ to $0.5 \mathrm{~m}$. However, the dominant Tp classes varied with the direction. The class from 4 $\mathrm{s}$ to $6 \mathrm{~s}(57.03 \%)$ was predominant for the typical NW direction, whereas the NE and N directions were predominant in the classes from $2 \mathrm{~s}$ to $4 \mathrm{~s}(52.63 \%)$ and $6 \mathrm{~s}$ to $8 \mathrm{~s}$ (37.00\%), respectively. The intervals of extreme values of Hs by directional class were $0.26 \mathrm{~m}$ to $0.70 \mathrm{~m}$ for NW, $0.50 \mathrm{~m}$ to $0.81 \mathrm{~m}$ for NE, and $0.52 \mathrm{~m}$ to $0.72 \mathrm{~m}$ for $\mathrm{N}$. The extreme values of Tp ranged from $9.59 \mathrm{~s}$ to $12.47 \mathrm{~s}$ for NW, $8.83 \mathrm{~s}$ to $13.32 \mathrm{~s}$ for NE, and 7.79 to $12.19 \mathrm{~s}$ for $\mathrm{N}$. 

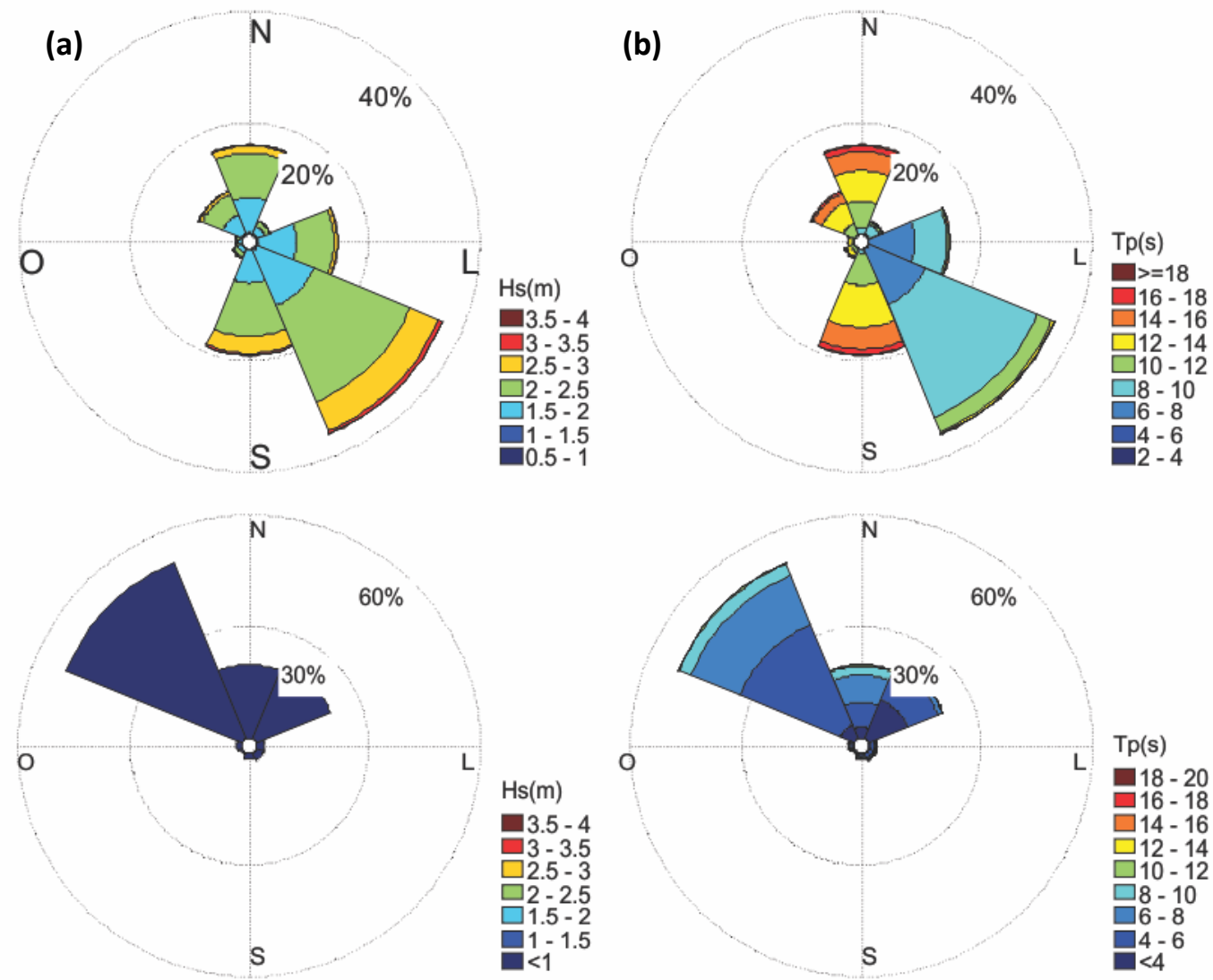

Figure 2.9. Wave climate at offshore and at lagoon of Rocas Atoll. (a) Directional histogram of significant wave height $(\mathrm{m})$ and $(\mathrm{b})$ directional histogram of the peak period $(\mathrm{s})$ of incident waves.

\subsubsection{Seasonality}

Figure 2.10 and Figure 2.11 show the monthly offshore wave climate characteristics, highlighting the seasonality of incident wave fields at Rocas Atoll. The waves from the SE quadrant are present throughout the year, reaching the atoll with greater intensity between July and October. Rocas Atoll experiences the effect of waves from the $\mathrm{N}$ and NW quadrant during the period from October to April, and February is the month with the strongest effect in the percentage of total occurrence of waves derived from this sector. Conversely, the waves coming from the $\mathrm{S}$ are prominent in May, June, July, August, and September, despite occurring at a low frequency in the other months. April is the transition between the $\mathrm{N}, \mathrm{NW}$, and $\mathrm{S}$ wave fields, displaying the most heterogeneous wave incidence conditions.

In the lagoon, the wave climate is very homogeneous throughout the year (Figure 2.12 and Figure 2.13). The NW direction is predominant throughout the year, and variation is only observed in the frequency of SE waves, which become more significant from May to November, with the increase in the number of offshore waves from the SE. 


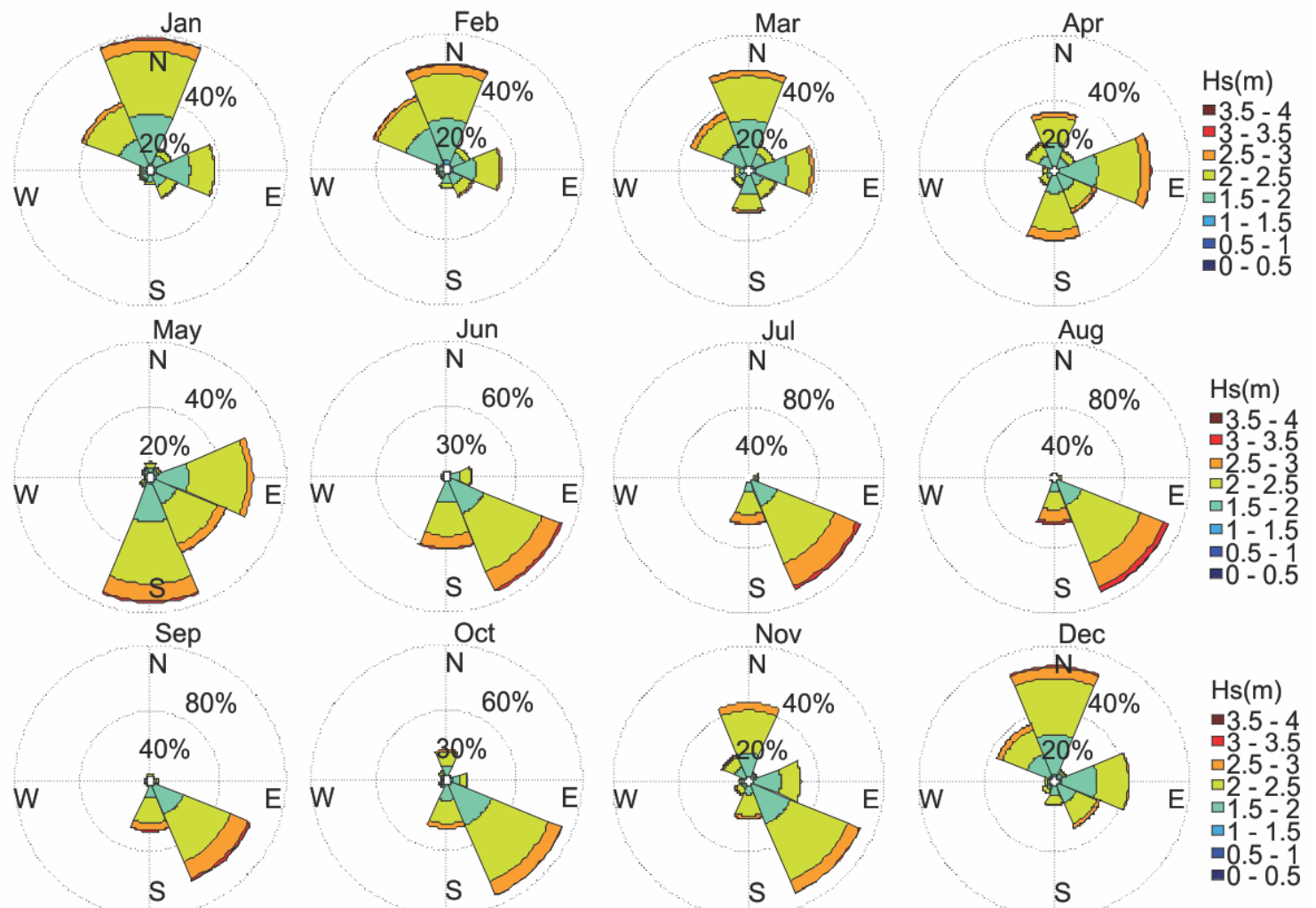

Figure 2.10. Monthly directional histograms of the significant offshore wave height (Hs).

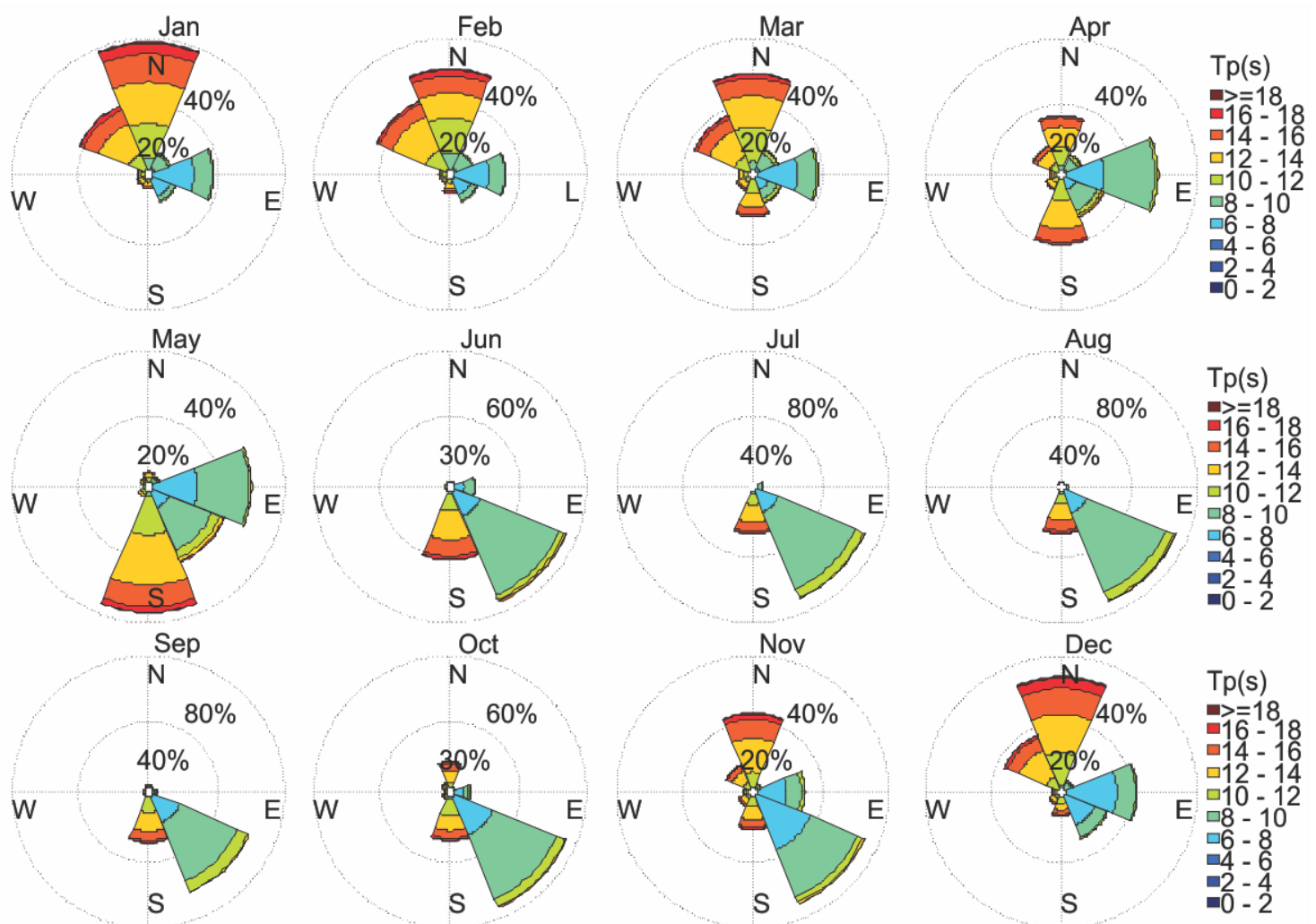

Figure 2.11. Monthly directional histograms of the offshore peak period (Tp). 


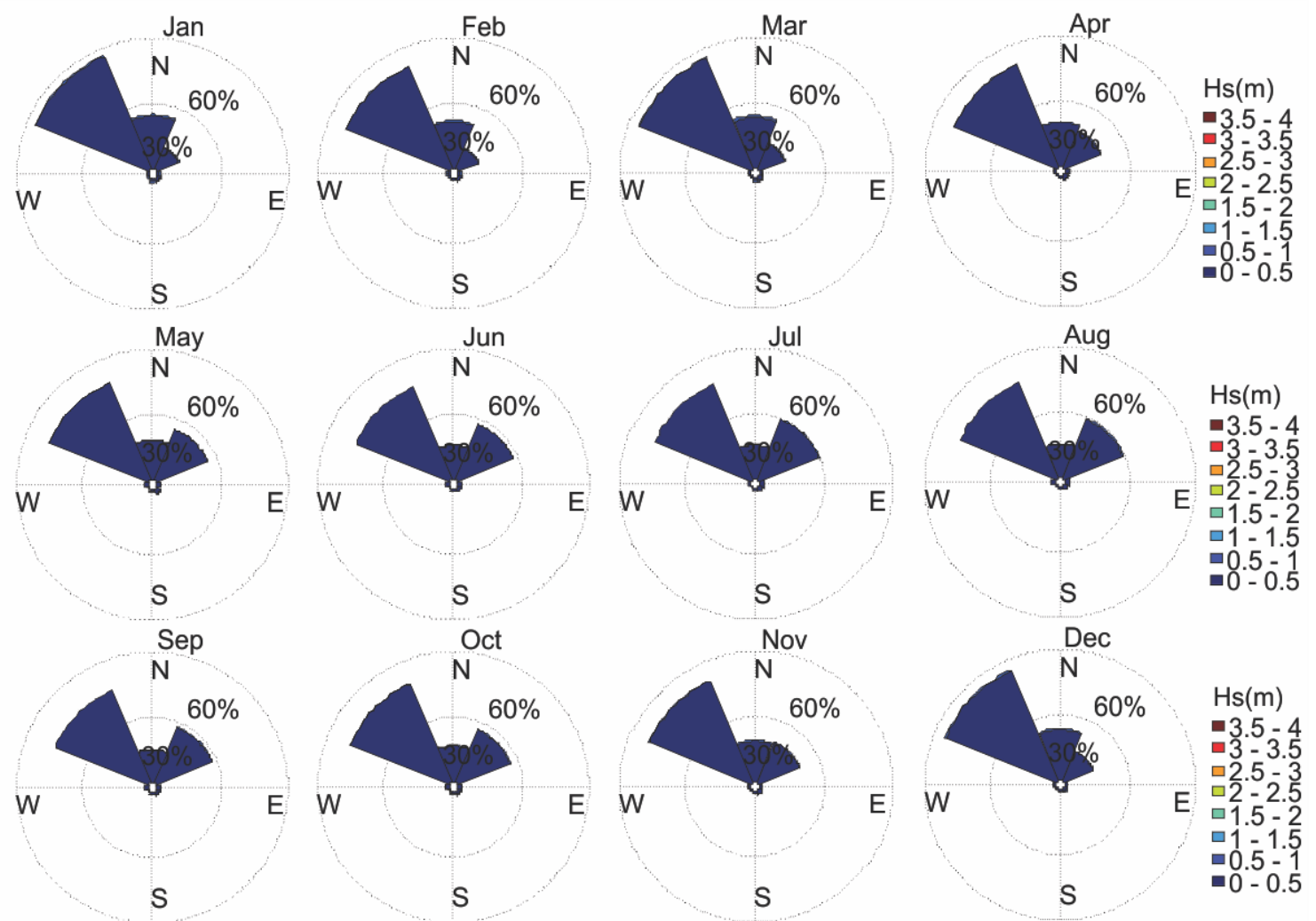

Figure 2.12. Monthly directional histograms of the significant lagoon wave height (Hs).
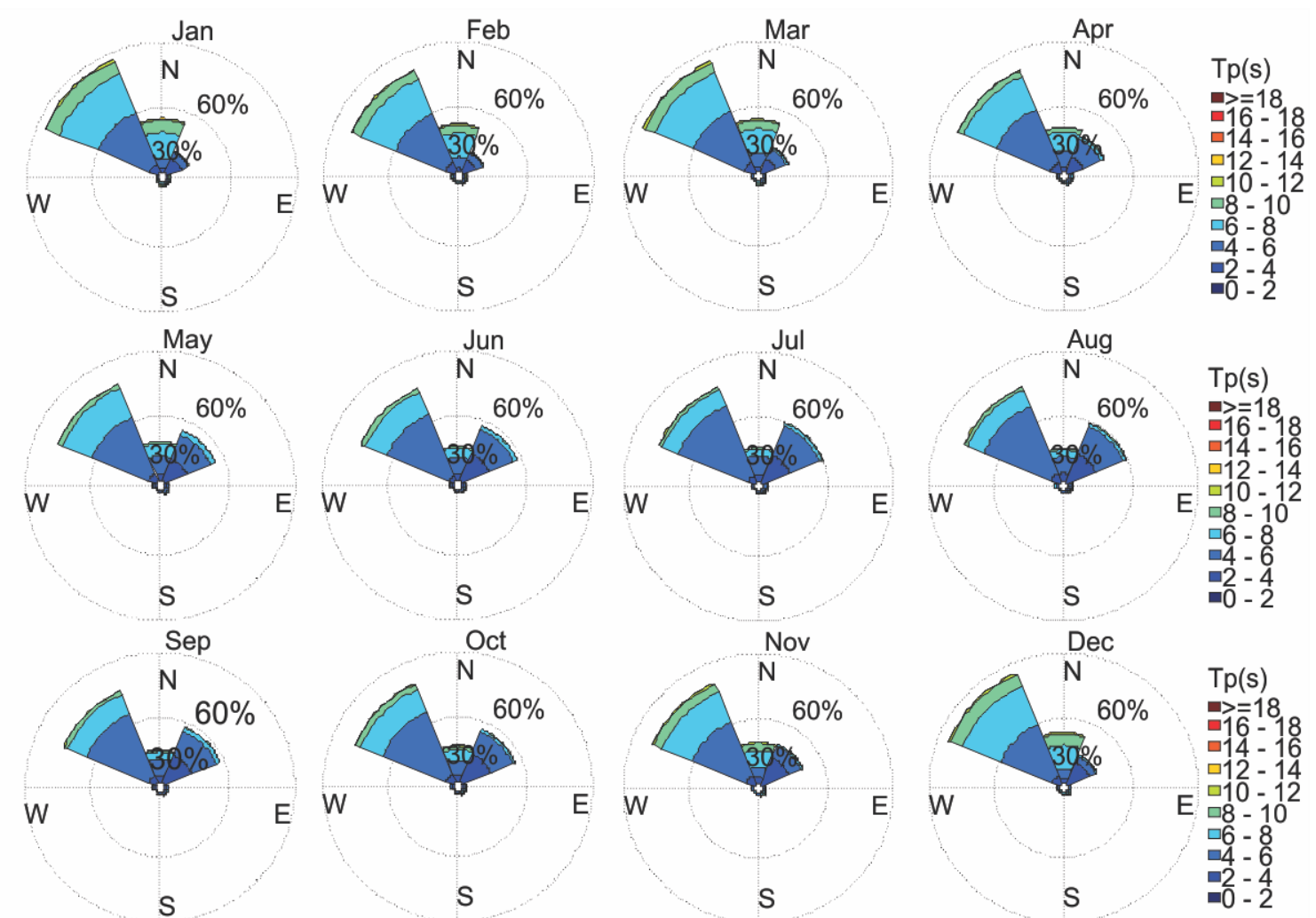

Figure 2.13. Monthly directional histograms of the lagoon peak period (Tp). 


\subsubsection{Tide and wave climate}

As showed above using in situ data, the tide has a strong effect on the lagoon wave height (Figure 2.6). The scatter plots show this relationship based on the 35 years of modeled data (Figure 2.14). The offshore wave conditions have no significant relationship with the tide $(p=0.6775)$. However, the variation in lagoon wave height is positively related to the tide $\left(p<0.05, R^{2}=0.87\right)$, with maximum height limits well defined according to the water level. The waves have a small $\mathrm{Hs}$ range (from $0 \mathrm{~m}$ to $0.20 \mathrm{~m}$ ) at low tide (from $0 \mathrm{~m}$ to $1 \mathrm{~m}$ ). The range increases to $0.5 \mathrm{~m}$ at intermediary (from $1 \mathrm{~m}$ to $2 \mathrm{~m}$ ) and high (higher than $2 \mathrm{~m}$ ) tides, and no waves higher than $0.5 \mathrm{~m}$ are found at intermediary tide or shorter than $0.2 \mathrm{~m}$ at high tide.
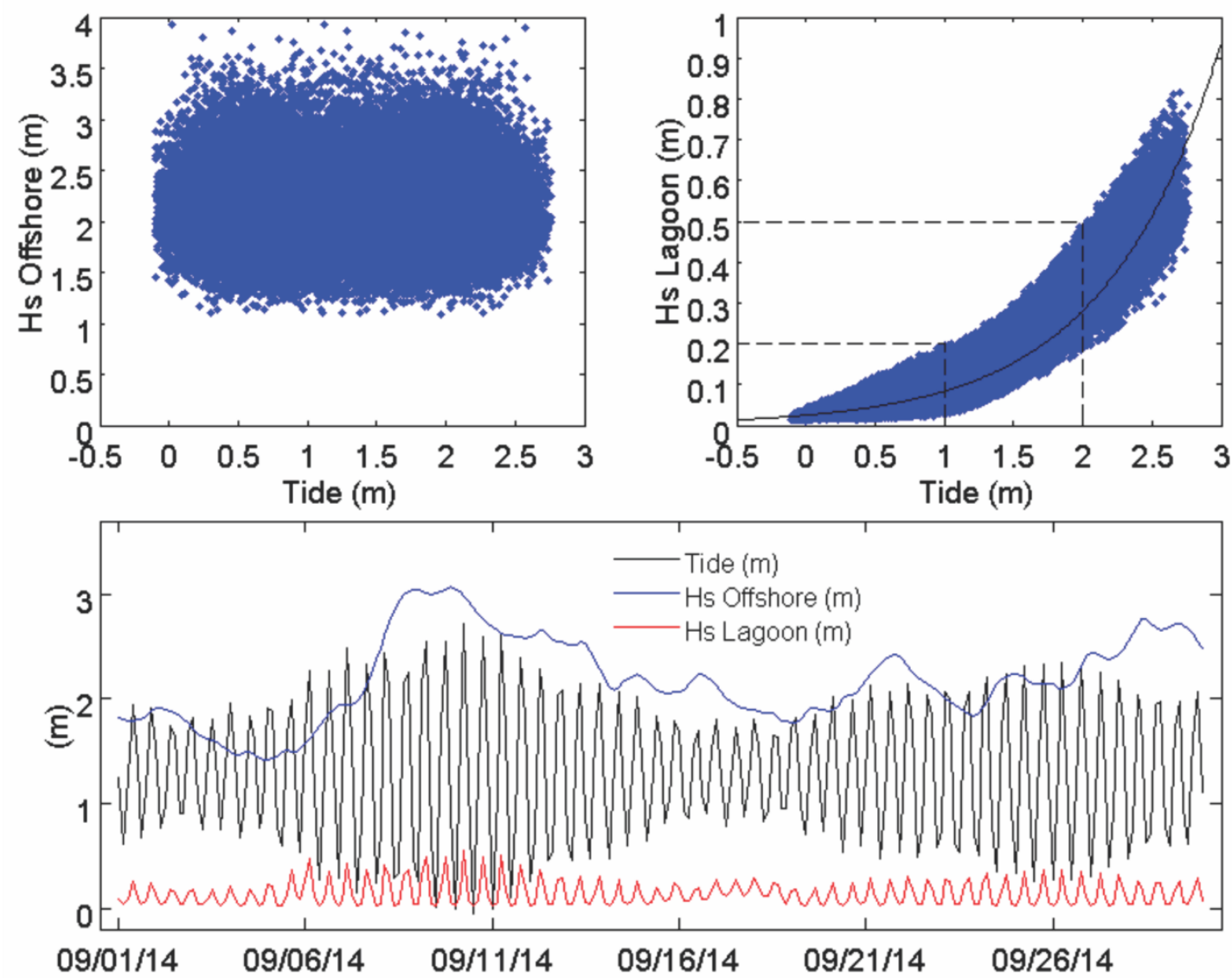

Figure 2.14. (a) Scatter plot of the tide (b) and offshore and lagoon wave and tide height. (c) Example of time series during September 2014 demonstrating the tidal oscillation and offshore and lagoon wave heights.

\subsubsection{Wave extremes}

Maximum annual offshore wave heights and periods at Rocas Atoll is summarized in Table 2.3 and Table 2.4. The maximum offshore wave heights occur mainly in August and are generated by events that occur in the Southern Hemisphere $(S, S W$, or SE wave directions). They are accompanied by peak periods averaging $12 \mathrm{~s}$. However, maximum wave height values derived from the Northern Hemisphere ( $N$, NW, or NE wave 
directions) are associated with higher peak period values (mean of $16.3 \mathrm{~s}$ ) that may represent more energetic conditions. These events from the Northern Hemisphere stand out as annual maxima, occurring only 5 times in 35 years and mostly in the 1980s. In turn, the occurrence of peak period annual maxima has a more homogeneous distribution in relation to the hemisphere of origin, although most are from the Northern Hemisphere (57\% of occurrences). They occur predominantly in December. The heights associated with the maximum periods do not exceed $3 \mathrm{~m}$, with a mean of $2 \mathrm{~m}$. The random tide values associated with the annual maxima are observed, highlighting the lack of relationship between the two variables.

The maximum annual lagoon wave heights occurred concurrently with the spring high tides. This finding was expected because higher waves may only propagate into the lagoon during high tides, demonstrating the tidal dependence of extreme wave conditions inside the atoll. The annual maxima of both Hs and Tp were preferentially northerly. However, nearly half the annual maxima of $\mathrm{Hs}(45 \%)$ were southerly.

Table 2.3. Summary of the maximum annual significant offshore wave heights (Hs) and peak period (Tp), with the associated hemisphere of incidence; and maximum annual offshore peak periods $(T p)$ and annual significant wave heights (Hs), with the associated hemisphere of incidence.

\begin{tabular}{cccccccccccc}
\hline \multicolumn{10}{c}{ Offshore } \\
\hline \multicolumn{1}{c}{ Maximum annual Hs } & \multicolumn{1}{c}{ Maximum annual Tp } \\
\hline Year & Month & Hs $(\mathrm{m})$ & $\mathrm{Tp}(\mathrm{s})^{*}$ & $\mathrm{D}^{*}$ & Tide $(\mathrm{m})$ & Year & Month & $\mathrm{Tp}(\mathrm{s})$ & $\mathrm{Hs}(\mathrm{m})^{*}$ & $\mathrm{D}^{*}$ & Tide $(\mathrm{m})$ \\
\hline 1980 & 8 & 3.45 & 8.35 & $\mathrm{~S}$ & 1.53 & 1980 & 2 & 20.26 & 1.7 & $\mathrm{~N}$ & 1.66 \\
1981 & 5 & 3.43 & 12.27 & $\mathrm{~S}$ & 0.36 & 1981 & 3 & 20.35 & 2.34 & $\mathrm{~S}$ & 2.1 \\
1982 & 2 & 3.93 & 16.19 & $\mathrm{~N}$ & 1.12 & 1982 & 4 & 20.33 & 1.99 & $\mathrm{~S}$ & 1.64 \\
1983 & 12 & 3.47 & 17.81 & $\mathrm{~N}$ & 1.94 & 1983 & 12 & 19.84 & 2.04 & $\mathrm{~N}$ & 1.25 \\
1984 & 11 & 3.09 & 15.61 & $\mathrm{~S}$ & 1.37 & 1984 & 8 & 20.42 & 1.99 & $\mathrm{~S}$ & 1.47 \\
1985 & 2 & 3.5 & 15.72 & $\mathrm{~N}$ & 1.44 & 1985 & 2 & 21.21 & 1.68 & $\mathrm{~N}$ & 0.38 \\
1986 & 6 & 3.24 & 8.98 & $\mathrm{~S}$ & 1.85 & 1986 & 12 & 19.06 & 1.85 & $\mathrm{~S}$ & 1.9 \\
1987 & 12 & 2.9 & 15.22 & $\mathrm{~N}$ & 1.98 & 1987 & 2 & 21.79 & 2.28 & $\mathrm{~N}$ & 1.62 \\
1988 & 7 & 3.49 & 9.64 & $\mathrm{~S}$ & 0.99 & 1988 & 11 & 20.58 & 2.15 & $\mathrm{~N}$ & 0.53 \\
1989 & 5 & 3.06 & 12.36 & $\mathrm{~S}$ & 1.46 & 1989 & 6 & 20.06 & 1.75 & $\mathrm{~S}$ & 2.3 \\
1990 & 6 & 3.05 & 8.83 & $\mathrm{~S}$ & 0.6 & 1990 & 11 & 19.74 & 2.19 & $\mathrm{~N}$ & 1.75 \\
1991 & 8 & 3.75 & 9.84 & $\mathrm{~S}$ & 2.12 & 1991 & 1 & 19.63 & 2.78 & $\mathrm{~N}$ & 0.4 \\
1992 & 9 & 3.19 & 9.86 & $\mathrm{~S}$ & 1.35 & 1992 & 9 & 18.5 & 1.91 & $\mathrm{~S}$ & 1.82 \\
1993 & 7 & 3.1 & 8.36 & $\mathrm{~S}$ & 0.23 & 1993 & 3 & 18.97 & 2.25 & $\mathrm{~N}$ & 0.58 \\
1994 & 7 & 2.97 & 15.47 & $\mathrm{~S}$ & 1.25 & 1994 & 12 & 19.11 & 1.59 & $\mathrm{~N}$ & 0.6 \\
1995 & 7 & 3.34 & 10.21 & $\mathrm{~S}$ & 2.05 & 1995 & 8 & 18.83 & 2.24 & $\mathrm{~S}$ & 0.27 \\
1996 & 9 & 3.86 & 11.45 & $\mathrm{~S}$ & 0.45 & 1996 & 1 & 20.03 & 2.27 & $\mathrm{~N}$ & 1.78 \\
1997 & 8 & 3.07 & 8.84 & $\mathrm{~S}$ & 0.09 & 1997 & 12 & 21.03 & 1.39 & $\mathrm{~N}$ & 0.2 \\
1998 & 8 & 3.03 & 10.55 & $\mathrm{~S}$ & 2.03 & 1998 & 11 & 20.37 & 1.83 & $\mathrm{~S}$ & 1.54 \\
1999 & 8 & 3.59 & 15.38 & $\mathrm{~S}$ & 0.9 & 1999 & 1 & 20.94 & 1.97 & $\mathrm{~N}$ & 2.16 \\
2000 & 9 & 3.27 & 11.72 & $\mathrm{~S}$ & 0.49 & 2000 & 12 & 19.11 & 2.02 & $\mathrm{~N}$ & 1.85
\end{tabular}


Table 2.3. (Continued).

\begin{tabular}{cccccccccccc}
\hline \multicolumn{10}{c}{ Offshore } \\
\hline \multicolumn{10}{c}{ Maximum annual Hs } & \multicolumn{10}{c}{ Maximum annual Tp } \\
\hline Year & Month & Hs (m) & Tp $(\mathrm{s})^{*}$ & $\mathrm{D}^{*}$ & Tide $(\mathrm{m})$ & Year & Month & $\mathrm{Tp}(\mathrm{s})$ & $\mathrm{Hs}(\mathrm{m})^{*}$ & $\mathrm{D}^{*}$ & Tide $(\mathrm{m})$ \\
\hline 2001 & 8 & 3.15 & 12.79 & $\mathrm{~S}$ & 2.03 & 2001 & 2 & 18.5 & 2.58 & $\mathrm{~N}$ & -0.01 \\
2002 & 8 & 3.7 & 10.93 & $\mathrm{~S}$ & 0.59 & 2002 & 3 & 20.72 & 1.77 & $\mathrm{~S}$ & 1.3 \\
2003 & 7 & 3.02 & 9.76 & $\mathrm{~S}$ & 2.01 & 2003 & 11 & 21.23 & 1.9 & $\mathrm{~N}$ & 1.78 \\
2004 & 8 & 3.31 & 11.07 & $\mathrm{~S}$ & 1.56 & 2004 & 8 & 19.02 & 2.17 & $\mathrm{~S}$ & 2.04 \\
2005 & 7 & 3.2 & 13.52 & $\mathrm{~S}$ & 1.25 & 2005 & 10 & 19.95 & 2.01 & $\mathrm{~N}$ & 0.28 \\
2006 & 7 & 3.63 & 9.83 & $\mathrm{~S}$ & 1.8 & 2006 & 3 & 18.55 & 1.66 & $\mathrm{~N}$ & -0.01 \\
2007 & 8 & 3.54 & 10.27 & $\mathrm{~S}$ & 0.45 & 2007 & 1 & 19.31 & 1.5 & $\mathrm{~N}$ & 1.72 \\
2008 & 8 & 3.57 & 11.31 & $\mathrm{~S}$ & 1.45 & 2008 & 9 & 18.77 & 2.44 & $\mathrm{~S}$ & 1.08 \\
2009 & 12 & 3.19 & 16.59 & $\mathrm{~N}$ & 0.63 & 2009 & 5 & 19.82 & 1.52 & $\mathrm{~S}$ & 2.28 \\
2010 & 9 & 3.51 & 10.28 & $\mathrm{~S}$ & 0.4 & 2010 & 2 & 19.62 & 1.79 & $\mathrm{~N}$ & 2.36 \\
2011 & 8 & 3.66 & 15.56 & $\mathrm{~S}$ & 2.1 & 2011 & 5 & 17.82 & 2.16 & $\mathrm{~S}$ & 1.8 \\
2012 & 8 & 3.54 & 10.35 & $\mathrm{~S}$ & 1.46 & 2012 & 7 & 19.27 & 2.18 & $\mathrm{~S}$ & 2.15 \\
2013 & 8 & 3.41 & 16.96 & $\mathrm{~S}$ & 0.44 & 2013 & 12 & 20.29 & 2.31 & $\mathrm{~N}$ & 1.82 \\
2014 & 5 & 3.37 & 17.6 & $\mathrm{~S}$ & 1.75 & 2014 & 8 & 20.14 & 2.25 & $\mathrm{~S}$ & 2.13 \\
\hline
\end{tabular}

* Associated values to $\mathrm{Hs}$ and $\mathrm{Tp}$.

Table 2.4. Summary of the maximum annual significant lagoon wave heights (Hs) and peak period (Tp), with the associated hemisphere of incidence; and maximum annual offshore wave peak periods (Tp) and annual significant wave heights (Hs), with the associated hemisphere of incidence.

\begin{tabular}{ccccccccccccc}
\hline \multicolumn{10}{c}{ Lagoon } \\
\hline \multicolumn{1}{c}{ Maximum annual Hs } & \multicolumn{1}{c}{ Maximum annual Tp } \\
\hline Year & Month & Hs $(\mathrm{m})$ & $\mathrm{Tp}(\mathrm{s})^{*}$ & $\mathrm{D}^{*}$ & Tide $(\mathrm{m})$ & Year & Month & $\mathrm{Tp}(\mathrm{s})$ & $\mathrm{Hs}(\mathrm{m})^{*}$ & $\mathrm{D}^{*}$ & Tide $(\mathrm{m})$ \\
\hline 1980 & 9 & 0.73 & 8.10 & $\mathrm{~N}$ & 2.73 & 1980 & 2 & 12.39 & 0.31 & $\mathrm{~N}$ & 1.66 \\
1981 & 3 & 0.81 & 11.84 & $\mathrm{~S}$ & 2.65 & 1981 & 2 & 12.32 & 0.59 & $\mathrm{~S}$ & 2.22 \\
1982 & 2 & 0.75 & 9.89 & $\mathrm{~S}$ & 2.57 & 1982 & 4 & 12.16 & 0.12 & $\mathrm{~N}$ & 1.04 \\
1983 & 1 & 0.68 & 7.51 & $\mathrm{~N}$ & 2.65 & 1983 & 12 & 12.13 & 0.22 & $\mathrm{~N}$ & 1.25 \\
1984 & 10 & 0.66 & 7.56 & $\mathrm{~S}$ & 2.60 & 1984 & 12 & 12.03 & 0.19 & $\mathrm{~N}$ & 1.07 \\
1985 & 2 & 0.73 & 12.20 & $\mathrm{~N}$ & 2.54 & 1985 & 7 & 12.47 & 0.13 & $\mathrm{~N}$ & 1.13 \\
1986 & 11 & 0.62 & 8.56 & $\mathrm{~S}$ & 2.46 & 1986 & 3 & 11.46 & 0.25 & $\mathrm{~N}$ & 1.38 \\
1987 & 2 & 0.79 & 11.12 & $\mathrm{~S}$ & 2.65 & 1987 & 2 & 13.32 & 0.34 & $\mathrm{~N}$ & 1.62 \\
1988 & 2 & 0.78 & 9.76 & $\mathrm{~N}$ & 2.76 & 1988 & 11 & 12.06 & 0.28 & $\mathrm{~N}$ & 1.46 \\
1989 & 3 & 0.72 & 9.06 & $\mathrm{~N}$ & 2.71 & 1989 & 9 & 11.65 & 0.14 & $\mathrm{~N}$ & 1.22 \\
1990 & 2 & 0.72 & 10.54 & $\mathrm{~S}$ & 2.58 & 1990 & 11 & 11.90 & 0.36 & $\mathrm{~N}$ & 1.75 \\
1991 & 1 & 0.77 & 11.32 & $\mathrm{~S}$ & 2.59 & 1991 & 1 & 11.84 & 0.20 & $\mathrm{~N}$ & 1.24 \\
1992 & 1 & 0.75 & 10.72 & $\mathrm{~S}$ & 2.68 & 1992 & 4 & 10.96 & 0.33 & $\mathrm{~N}$ & 1.69 \\
1993 & 10 & 0.68 & 7.68 & $\mathrm{~N}$ & 2.62 & 1993 & 9 & 11.14 & 0.20 & $\mathrm{~N}$ & 1.25 \\
1994 & 2 & 0.76 & 10.03 & $\mathrm{~S}$ & 2.65 & 1994 & 12 & 11.55 & 0.23 & $\mathrm{~N}$ & 1.41 \\
1995 & 1 & 0.74 & 10.61 & $\mathrm{~N}$ & 2.64 & 1995 & 3 & 11.03 & 0.20 & $\mathrm{~N}$ & 1.20 \\
1996 & 1 & 0.72 & 9.60 & $\mathrm{~N}$ & 2.67 & 1996 & 1 & 12.17 & 0.39 & $\mathrm{~N}$ & 1.78 \\
1997 & 3 & 0.70 & 7.44 & $\mathrm{~N}$ & 2.72 & 1997 & 12 & 12.26 & 0.16 & $\mathrm{~N}$ & 1.00 \\
& & & & & & & & & & &
\end{tabular}


Table 2.4. (Continued).

\begin{tabular}{cccccccccccc}
\hline \multicolumn{10}{c}{ Lagoon } \\
\hline \multicolumn{10}{c}{ Maximum annual Hs } \\
\hline Year & Month & Hs $(\mathrm{m})$ & $\mathrm{Tp}(\mathrm{s})^{*}$ & $\mathrm{D}^{*}$ & Tide $(\mathrm{m})$ & Year & Month & $\mathrm{Tp}(\mathrm{s})$ & $\mathrm{Hs}(\mathrm{m})^{*}$ & $\mathrm{D}^{*}$ & Tide $(\mathrm{m})$ \\
\hline 1998 & 3 & 0.70 & 7.47 & $\mathrm{~N}$ & 2.70 & 1998 & 11 & 12.29 & 0.12 & $\mathrm{~N}$ & 1.07 \\
1999 & 10 & 0.80 & 11.94 & $\mathrm{~N}$ & 2.63 & 1999 & 1 & 12.87 & 0.55 & $\mathrm{~S}$ & 2.16 \\
2000 & 1 & 0.68 & 7.86 & $\mathrm{~S}$ & 2.61 & 2000 & 12 & 11.60 & 0.39 & $\mathrm{~N}$ & 1.85 \\
2001 & 2 & 0.81 & 11.50 & $\mathrm{~N}$ & 2.70 & 2001 & 2 & 11.50 & 0.81 & $\mathrm{~N}$ & 2.70 \\
2002 & 10 & 0.73 & 8.72 & $\mathrm{~N}$ & 2.71 & 2002 & 3 & 12.18 & 0.14 & $\mathrm{~N}$ & 1.30 \\
2003 & 4 & 0.74 & 9.41 & $\mathrm{~N}$ & 2.67 & 2003 & 11 & 12.89 & 0.37 & $\mathrm{~N}$ & 1.78 \\
2004 & 1 & 0.70 & 9.07 & $\mathrm{~S}$ & 2.58 & 2004 & 1 & 11.17 & 0.25 & $\mathrm{~N}$ & 1.40 \\
2005 & 10 & 0.72 & 10.76 & $\mathrm{~S}$ & 2.54 & 2005 & 10 & 11.87 & 0.24 & $\mathrm{~N}$ & 1.36 \\
2006 & 3 & 0.77 & 10.71 & $\mathrm{~N}$ & 2.71 & 2006 & 3 & 10.75 & 0.18 & $\mathrm{~N}$ & 1.14 \\
2007 & 2 & 0.74 & 9.48 & $\mathrm{~N}$ & 2.70 & 2007 & 1 & 11.82 & 0.21 & $\mathrm{~N}$ & 1.34 \\
2008 & 1 & 0.65 & 8.60 & $\mathrm{~S}$ & 2.56 & 2008 & 9 & 11.10 & 0.13 & $\mathrm{~N}$ & 1.08 \\
2009 & 2 & 0.72 & 8.61 & $\mathrm{~N}$ & 2.66 & 2009 & 5 & 11.60 & 0.11 & $\mathrm{~N}$ & 1.16 \\
2010 & 1 & 0.72 & 7.30 & $\mathrm{~S}$ & 2.74 & 2010 & 2 & 11.99 & 0.60 & $\mathrm{~S}$ & 2.36 \\
2011 & 2 & 0.73 & 8.55 & $\mathrm{~N}$ & 2.74 & 2011 & 1 & 10.74 & 0.22 & $\mathrm{~N}$ & 1.33 \\
2012 & 2 & 0.68 & 9.88 & $\mathrm{~S}$ & 2.56 & 2012 & 1 & 10.78 & 0.21 & $\mathrm{~N}$ & 1.34 \\
2013 & 3 & 0.69 & 9.95 & $\mathrm{~S}$ & 2.51 & 2013 & 12 & 12.34 & 0.48 & $\mathrm{~N}$ & 2.01 \\
2014 & 1 & 0.70 & 7.52 & $\mathrm{~N}$ & 2.71 & 2014 & 1 & 11.51 & 0.68 & $\mathrm{~N}$ & 2.53 \\
\hline
\end{tabular}

* Associated values to $\mathrm{Hs}$ and $\mathrm{Tp}$.

The Hs and Tp maxima are not necessarily associated, as shown in Table 2.3 and Table 2.4. The analysis joint occurrence of $\mathrm{Hs}$ and $\mathrm{Tp}$ by wave power parameter, ranged from $4.54 \mathrm{~kW} / \mathrm{m}$ to $142.53 \mathrm{~kW} / \mathrm{m}$, averaging $27.98 \mathrm{~kW} / \mathrm{m}$ offshore. The "Moderate" intensity class was the most common in the region. Conversely, the lagoon wave power was restricted to a range from $0 \mathrm{~kW} / \mathrm{m}$ to $4.46 \mathrm{~kW} / \mathrm{m}$, averaging $0.14 \mathrm{~kW} / \mathrm{m}$, with all events falling within the "Calm" class. Offshore, the class of extreme wave force events accounted for $5.96 \%$ of all occurrences (Figure 2.15 ). 

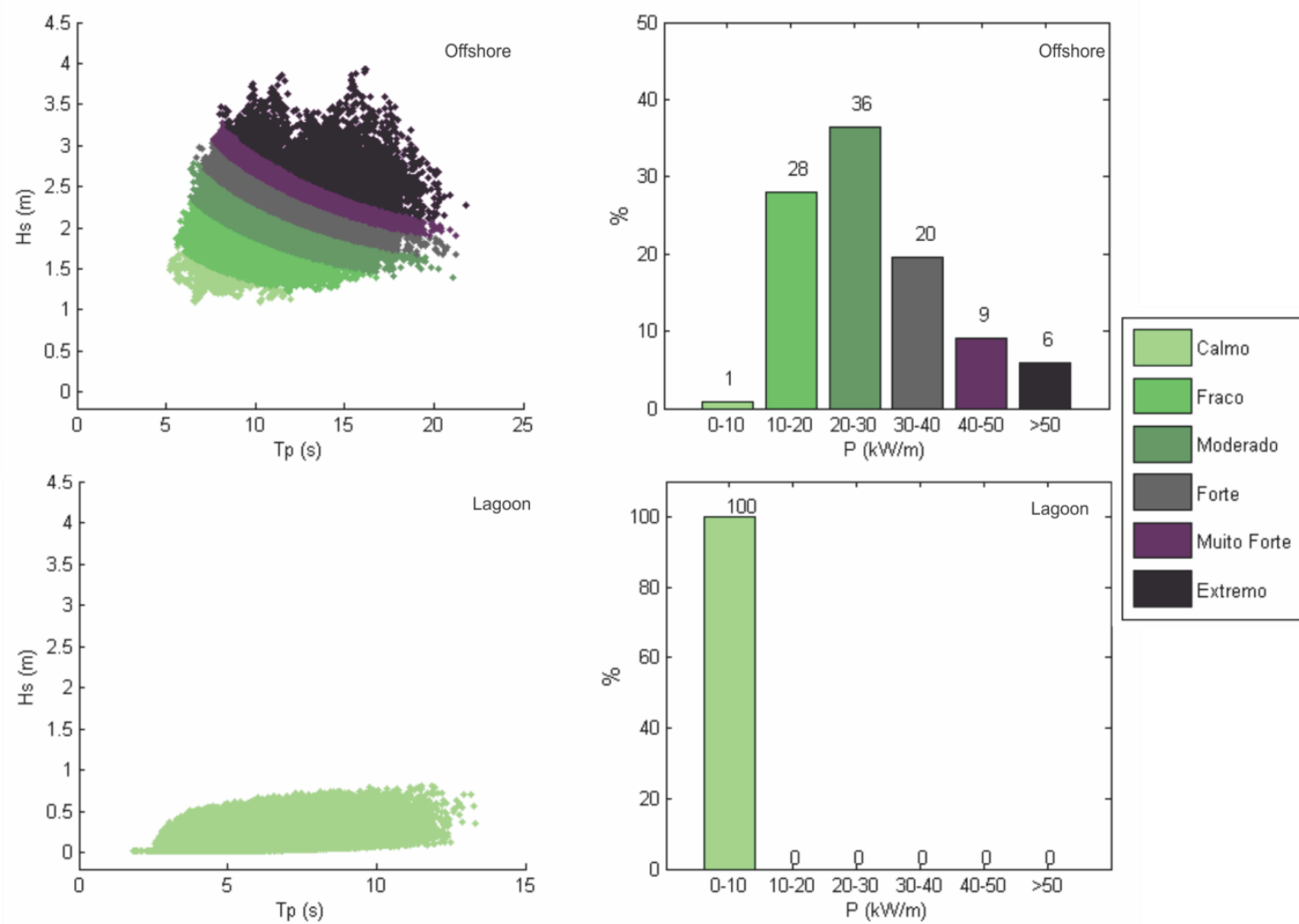

Figure 2.15. (a) Scatter plot of combined occurrences of significant wave height (Hs) and peak period $(\mathrm{Tp})$ and $(\mathrm{b})$ histogram of wave power $(\mathrm{P})$ during the 35 -year interval. The color scale represents the wave intensity classes. The values above each bar are the rounded percentage of occurrence values.

The analysis of the frequency of classes by offshore direction demonstrates that most extreme events reached the atoll from processes formed in the Southern and Northern Hemispheres. Events stronger than $80 \mathrm{~kW} / \mathrm{m}$ had a similar $\mathrm{N}$ and $\mathrm{S}$ distribution $13.19 \%$ from $\mathrm{N}$ and $3.14 \%$ from $\mathrm{S}$ ), and events stronger than $90 \mathrm{~kW} / \mathrm{m}$ were predominantly northerly (1.32\% from $\mathrm{N}$ and $1.04 \%$ from $\mathrm{S})$.
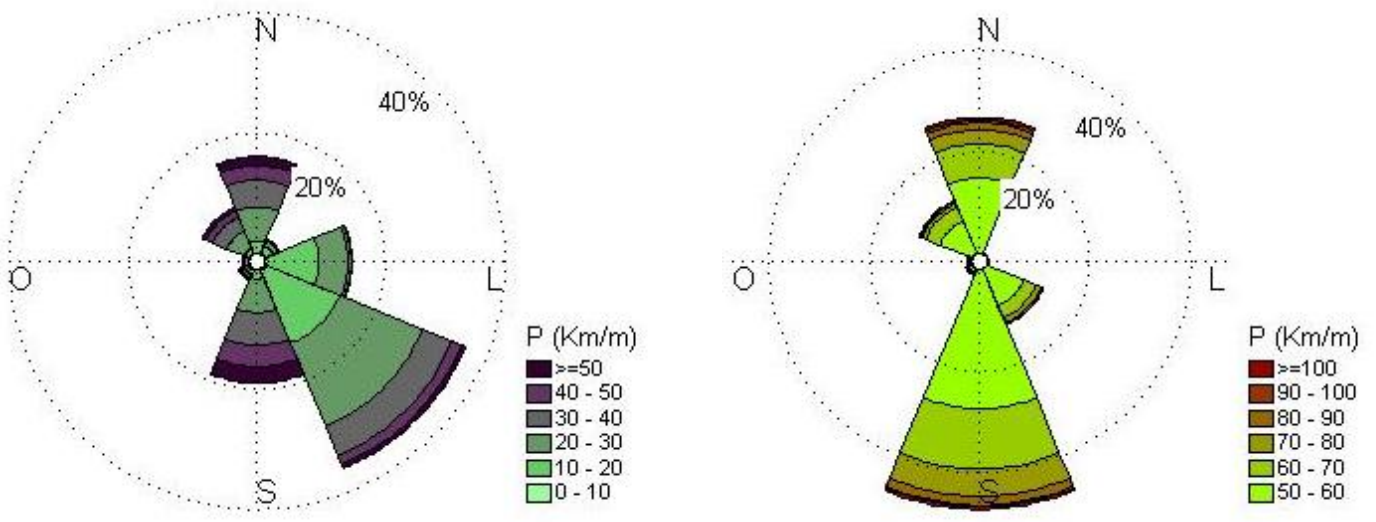

Figure 2.16. Directional histogram of wave power $(P)$ for the (a) total dataset and (b) the class of extremes only $(P \geq 50 \mathrm{~kW} / \mathrm{m})$. 


\subsubsection{Return periods}

To establish the mean return periods of extreme events for Rocas Atoll, the Generalized Extreme Value (GEV) model was used to extrapolate the extreme values beyond the range available in the original series. The GEV model was applied to the series of offshore and lagoon annual maximum values (of $\mathrm{Hs}, \mathrm{Tp}$, and $\mathrm{P}$ ), using the maximum likelihood estimation (MLE) method to estimate the model parameters. No estimates beyond 100 years were used because the forecast uncertainty increases with the analysis period and because estimates not exceeding twice the length of the time series used ( 35 years in this case) are recommended. Figure 2.17 contains the GEV fit-quality plots for the series of annual maxima of wave parameters.
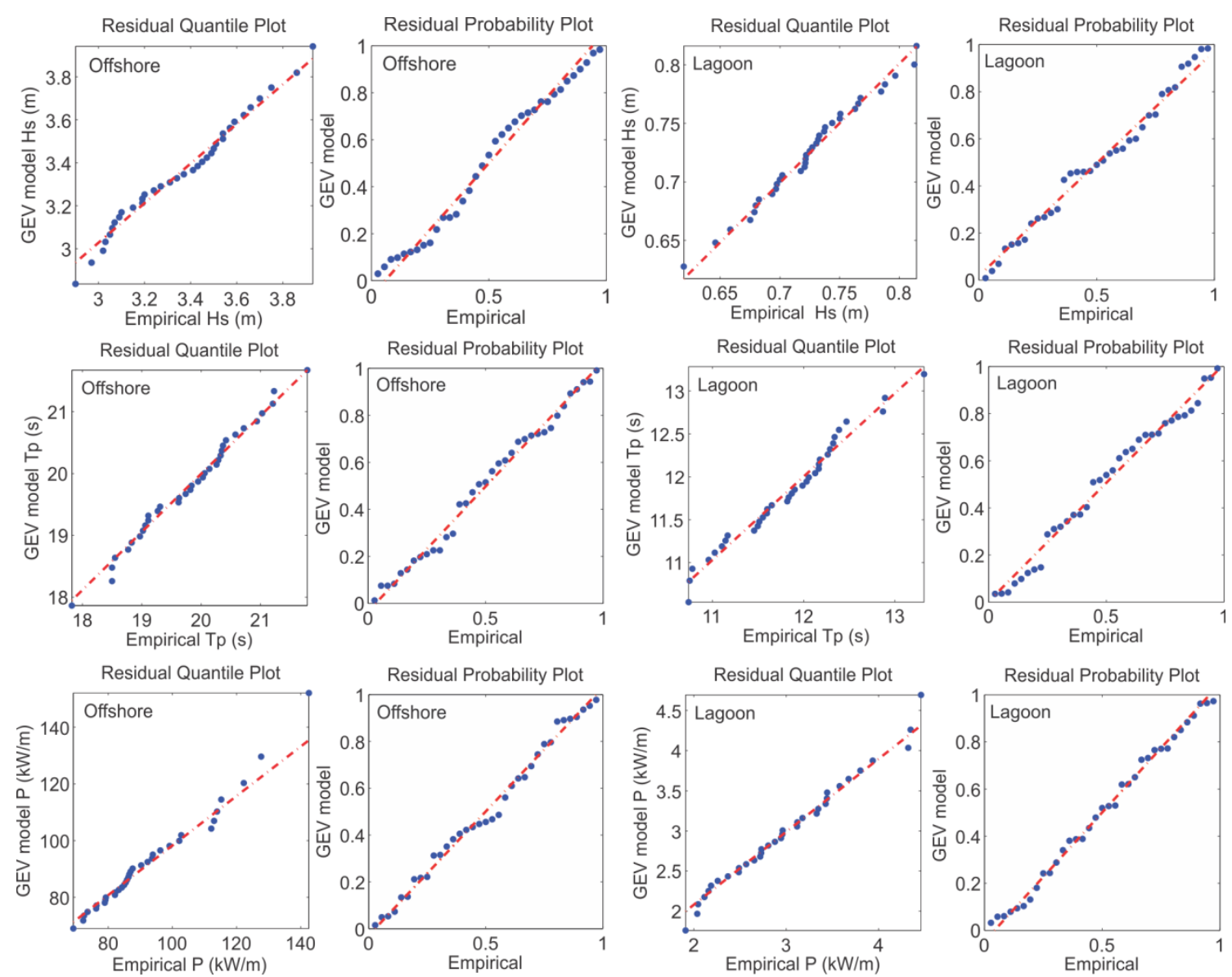

Figure 2.17. Probability and quantile plots corresponding to the 35 -year maximum values fit to the Generalized Extreme Value (GEV) distribution.

The maximum event observed in the 35-year series, which occurred in February 1982 $(P=142 \mathrm{~kW} / \mathrm{m})$, has a return period of approximately 38 years (Figure 2.18). This event occurred together with a spring tide with a height of $2.57 \mathrm{~m}$, resulting in conditions of $3.18 \mathrm{~kW} / \mathrm{m} \mathrm{P}$ and $0.75 \mathrm{~m}$ and $9.88 \mathrm{~s} \mathrm{Hs}$ and Tp, respectively, in the lagoon. Conversely, 
the largest wave event recorded in the lagoon occurred in March 1981 during a spring tide of $2.65 \mathrm{~m}$, with waves of $0.81 \mathrm{~m}$ and $11.84 \mathrm{~s}$, resulting in $4.46 \mathrm{~kW} / \mathrm{m} \mathrm{P}$.

Offshore events with Hs higher than $3.75 \mathrm{~m}$ or Tp longer than $21.29 \mathrm{~s}$ and $\mathrm{P}$ greater than $118.31 \mathrm{~kW} / \mathrm{m}$ had return periods longer than 10 years and a $10 \%$ annual probability of exceedance. Table 2.5 outlines the return periods of $2,5,10,25,50$, and 100 of $\mathrm{Hs}, \mathrm{Tp}$, and $\mathrm{P}$ magnitudes; the probability of exceedance of each of these periods at any year is $50 \%, 20 \%, 10 \%, 4 \%, 2 \%$, and $1 \%$, respectively.
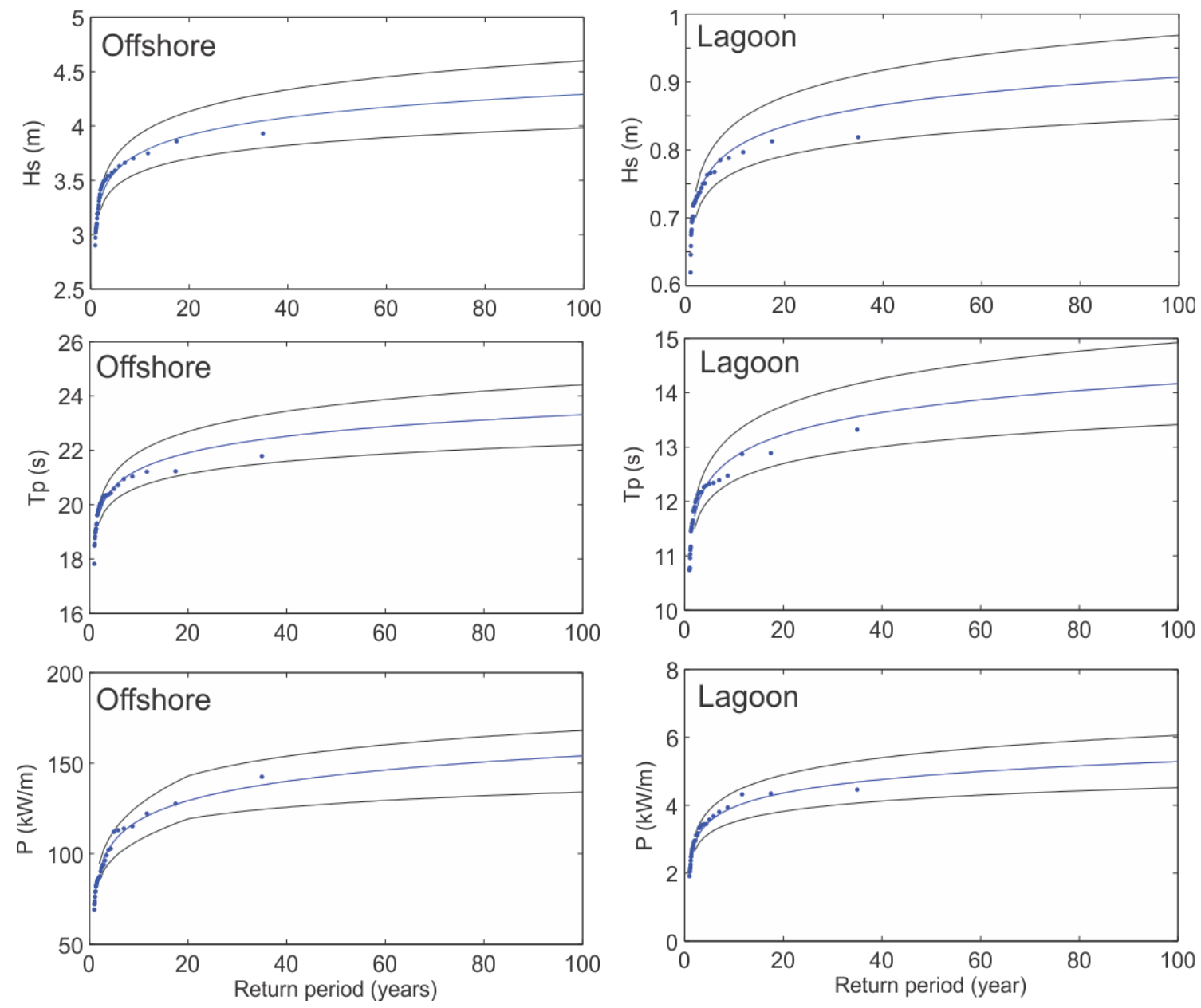

Figure 2.18. Return period of wave extremes estimated using the GEV distribution based on the 35-year time series of $\mathrm{Hs}, \mathrm{Tp}$, and P for offshore and Hs, Tp, and P for the lagoon.

Furthermore, Table 2.6 presents the highest wave force values and their associated direction. Offshore extreme events $(>50 \mathrm{~kW} / \mathrm{m}$ ) showed annual reoccurrence with a frequency of 5 per year, originating in both the Northern and the Southern Hemispheres. However, events with a magnitude higher than $95 \mathrm{~kW} / \mathrm{m}$ occurred on average every 3 years, and in 4 of the 12 years that events of this magnitude occurred, they occurred twice in the same year. Thus, it is expected that an extreme event may occur twice in the same year in which it first occurs. Another observation concerns the distribution according to direction. In the last 35 years, extreme events from the $\mathrm{N}$ occurred mainly in the 1980s, at approximately 1-year intervals between 1981 and 
1985, whereas the events from the $S$ occurred mainly in the last decade, at approximately 2-year intervals between 2007 and 2014.

The maximum events in the lagoon did not necessarily occur in the same order of offshore events. The occurrence of these events was related to a spring tide with at least $2.50 \mathrm{~m}$ in height. These events occurred from October to March (preferentially in February), months that correspond to the predominance of incidence of events originating in the Northern Hemisphere (Figure 2.10 and Figure 2.11). Regarding direction, the classes outlined in Table 2.6 reflect the direction of wave entry into the lagoon, which is not necessarily its direction of propagation in the open ocean.

Table 2.5. Estimates of wave extremes for the various return periods, based on the 35 -year offshore time series for Rocas Atoll.

\begin{tabular}{ccccccc}
\hline \multirow{2}{*}{$\begin{array}{c}\text { Return period } \\
\text { (years) }\end{array}$} & \multicolumn{3}{c}{ Offshore } & \multicolumn{3}{c}{ Lagoon } \\
\cline { 2 - 7 } & $\mathrm{Hs}(\mathrm{m})$ & $\mathrm{Tp}(\mathrm{s})$ & $\mathrm{P}(\mathrm{kW} / \mathrm{m})$ & $\mathrm{Hs}(\mathrm{m})$ & $\mathrm{Tp}(\mathrm{s})$ & $\mathrm{P}(\mathrm{kW} / \mathrm{m})$ \\
\hline 2 & 3.32 & 19.66 & 89.63 & 0.72 & 11.73 & 2.87 \\
5 & 3.56 & 20.64 & 106.88 & 0.77 & 12.38 & 3.52 \\
10 & 3.75 & 21.29 & 118.31 & 0.80 & 12.81 & 3.95 \\
25 & 3.97 & 22.1 & 132.74 & 0.85 & 13.36 & 4.49 \\
50 & 4.13 & 22.71 & 147.44 & 0.88 & 13.76 & 4.89 \\
100 & 4.29 & 23.31 & 154.07 & 0.91 & 14.12 & 5.23 \\
\hline
\end{tabular}

Table 2.6. Most energetic wave events recorded at offshore of Rocas Atoll in the last $\mathbf{3 5}$ years (1980-2014), using the occurrence of $1 \%$ of the total number of events of the classes of extremes $(>50 \mathrm{~kW} / \mathrm{m})$ and considering the peak of each event.

\begin{tabular}{cccccccccc}
\hline \multicolumn{8}{c}{ 1\% of $\mathrm{P}(\mathrm{kW} / \mathrm{m})$} & maximum values \\
\hline \multicolumn{7}{c}{ Offshore } \\
\hline Year & Month & $\mathrm{P}(\mathrm{kW} / \mathrm{m})$ & Tide $(\mathrm{m})$ & Direction & Year & Month & $\mathrm{P}(\mathrm{kW} / \mathrm{m})$ & Tide $(\mathrm{m})$ & Direction \\
\hline 1982 & 2 & 142.53 & 2.57 & $\mathrm{~N}$ & 1981 & 3 & 4.46 & 2.65 & $\mathrm{NE}$ \\
2011 & 8 & 127.65 & 2.13 & $\mathrm{~S}$ & 2001 & 2 & 4.35 & 2.70 & $\mathrm{NE}$ \\
1983 & 12 & 122.24 & 1.94 & $\mathrm{~N}$ & 1999 & 10 & 4.32 & 2.63 & $\mathrm{NE}$ \\
2013 & 8 & 115.22 & 2.10 & $\mathrm{~S}$ & 1987 & 2 & 3.94 & 2.65 & $\mathrm{NE}$ \\
2014 & 5 & 113.93 & 2.31 & $\mathrm{~S}$ & 1991 & 1 & 3.80 & 2.59 & $\mathrm{NE}$ \\
1999 & 8 & 112.98 & 2.31 & $\mathrm{~S}$ & 1985 & 2 & 3.67 & 2.54 & $\mathrm{NE}$ \\
1985 & 2 & 112.12 & 2.54 & $\mathrm{NO}$ & 2006 & 3 & 3.58 & 2.71 & $\mathrm{NE}$ \\
1999 & 1 & 106.06 & 2.52 & $\mathrm{~N}$ & 2005 & 10 & 3.44 & 2.51 & $\mathrm{NE}$ \\
2007 & 8 & 102.74 & 2.31 & $\mathrm{SE}$ & 1992 & 1 & 3.44 & 2.68 & $\mathrm{NE}$ \\
1985 & 12 & 102.35 & 1.91 & $\mathrm{~N}$ & 1999 & 1 & 3.43 & 2.52 & $\mathrm{NE}$ \\
1996 & 8 & 102.16 & 1.97 & $\mathrm{~S}$ & 1988 & 2 & 3.43 & 2.76 & $\mathrm{NE}$ \\
1981 & 5 & 99.11 & 2.14 & $\mathrm{~S}$ & 1995 & 1 & 3.35 & 2.64 & $\mathrm{NE}$ \\
1981 & 3 & 98.01 & 2.65 & $\mathrm{NO}$ & 1994 & 2 & 3.33 & 2.65 & $\mathrm{NE}$ \\
1996 & 9 & 97.24 & 1.81 & $\mathrm{SE}$ & 1982 & 2 & 3.18 & 2.57 & $\mathrm{NE}$ \\
2009 & 12 & 96.23 & 2.04 & $\mathrm{~N}$ & 1990 & 2 & 3.12 & 2.58 & $\mathrm{NE}$ \\
\hline
\end{tabular}




\subsection{Discussion}

\subsubsection{Offshore wave climate}

The results of the analysis of typical and seasonal conditions display the wide directional variability of wave events that characterize the wave climate in the oceanic region of Rocas Atoll (offshore). Because it is located at low latitudes, this region is exposed to a regime of sea surface waves formed as much by waves generated by local winds (wind waves) as by waves generated by distant winds (swell) in both hemispheres. The local winds acting in the southern equatorial region where Rocas Atoll is located are the southeast trade winds (Ferreira 1996), which are responsible for the formation of wind waves. Conversely, swells are formed by distant weather events, including extratropical cyclones in the Northern and Southern Hemispheres and East African atmospheric waves (Innocentini et al., 2005).

The direction of wave incidence at Rocas is subject to annual seasonality, which is affected by the wind regimes at synoptic scale. The wave incidents on the Rocas Atoll may be categorized into three groups according to their period characteristics and associated direction:

Group 1: SE octant waves, present in the atoll during the entire year, are wind waves, formed by local wave fields forced by southeast trade winds. These winds accompany semi-permanent anticyclones of the North Atlantic and South Atlantic, and they experience a southern shift according to the annual solar cycle, intensifying from July to October (Innocentini et al., 2005). Offshore winds of up to $14 \mathrm{~m} / \mathrm{s}$ may be found during this period. E octant waves are also wind sea waves and have lower energy than southeasterly waves, and they are most likely associated with periods of shift to the south of the Intertropical Convergence Zone and the local weakening of trade winds.

Group 2: The waves derived from the $\mathrm{N}$ and NW that reach the atoll region are swell waves, generated in wind fields acting in the Northern Hemisphere that intensify during the winter of this hemisphere and have the ability to propagate throughout much of the Atlantic Ocean basin. Thus, these waves reflect the sea agitation generated by surface winds that accompany extratropical cyclones, which are very intense during this season off the northeastern sector of the North Atlantic (Innocentini et al., 2005).

Group 3: The S and SW octant waves and the N and NW octant waves are swell waves and reach Rocas Atoll with greater intensity during the winter months of the Southern Hemisphere. They are mainly generated at latitudes higher than $40^{\circ} \mathrm{S}$ and propagate northerly and northeasterly, losing energy during this process. On the south coast of Brazil, waves higher than $5 \mathrm{~m}$ may move to the coastal zone (Pianca et al., 2010). Conversely, in the Rocas Atoll region, waves with this value are not observed, and the occurrence of waves higher than $3 \mathrm{~m}$ derived from the Southern Hemisphere is rare. 
The three main groups of waves may occur simultaneously throughout the year. In particular, group 1 occurs almost all year round, always overlapping with group 2 and/or 3, given the permanent southeasterly trade winds in the region. Conversely, these last 2 groups tend to switch seasonally, depending on the seasonal variation in wind intensity at high latitudes and the ratio of incidence throughout Rocas; the swell from both hemispheres exhibits a similar frequency.

The Hs values exhibited low variability and mild conditions compared to the wave climate of high-latitude regions, despite the high directional variability of incident waves at Rocas Atoll (Young, 1999). Such characteristics also result from the location of the atoll in the equatorial region. The zonal (latitudinal) distribution of $\mathrm{Hs}$ in the globe shows that the highest wave conditions are observed at higher latitudes. This observation is particularly clear in the southern ocean, where intense wave conditions are observed year round, despite peaking during winter in the Southern Hemisphere (July-August) (Young, 1999). Furthermore, the west coasts of continents receive more energy derived from swell propagation originating at high latitudes because of the propagation towards the northeast along the great circle path from these (Young, 1999). Rocas, which is located near the east coast of South America, receives less swell energy compared to the equatorial region near the coast of Africa.

Lastly, its position slightly south of the equator allows the atoll to remain outside the path of Atlantic tropical cyclones, which are formed in latitudes between $5^{\circ}$ and $30^{\circ} \mathrm{N}$ and typically move westward (Colbert and Soden, 2012; Emanuel, 2003). These 3 factors with regard to the atoll's location allow mild wave conditions throughout the year.

\subsubsection{Lagoon wave climate}

The results show that offshore waves are significantly changed when propagating into the lagoon, resulting in a different and far more homogeneous inner wave climate. The atoll morphology and tides particularly play a key role in controlling the directional and energy characteristics of the wave climate in the lagoon.

The directional variability in the lagoon is mainly restricted to the $\mathrm{N}, \mathrm{NW}$, and NE directions, which match the direction of the main reef passage (Barretão), indicating that waves penetrate the lagoon mainly through this passage. In particular, the typical direction of wave propagation in the lagoon is opposite to the typical direction of offshore waves, showing the refraction effect of offshore waves from various directions in the vicinity of the atoll rim and penetration through the channel.

Although Barretão is located in the zone protected from the constant SE waves, the results suggest that this zone is the most energetic zone of wave propagation in the lagoon throughout the year because of the refraction process. Spatial differences in 
the type and magnitude of wave energy are generally found on atolls due to differences in the reef flat elevation (Kench, 1998a), and more energetic waves should be found in the vicinity of reef passages (Aucan et al., 2012). These studies also highlight the dependence of the wave lagoon characteristics on atoll morphology.

In terms of wave energy, the significant wave height in the Rocas Atoll lagoon is approximately $60 \%$ smaller than offshore, and it typically does not exceed $0.8 \mathrm{~m}$, even during the incidence of energetic ocean swells (for example, incidence of offshore Hs of $3.5 \mathrm{~m}$ ). The reduction in the wave height occurs through energy dissipation when the wave interacts with the reef structure (Kench et al., 2006). In addition to attenuation by depth-limited breaking, waves propagating across the reef flat or narrow channels in the reef can dissipate significant amounts of energy to bottom friction (Lowe, 2005; Lowe et al., 2009a). Thus, the reef rim serves as a low-pass wave height filter by filtering out waves with heights larger than the depth-limited maximum (Lowe, 2005). In combination with bottom friction, it imposes major constraints on ocean swell, leading to dramatic transformations in wave characteristics and the consequent rapid attenuation of wave energy (Kench and Brander, 2006b).

The results at Rocas show a clear separation between lagoon wave height values according to the tide level. Wave height variability, despite having a smaller range than the offshore waves, occurs in a shorter and more regular period of time. The waves vary in a 6-h scale, according to the high and low tide level at the time. This strong modulation results from the water level in the reef edge and in the Barretão passage. The topography of the Rocas Atoll rim is irregular, with the highest parts in the windward region and the lowest parts in the leeward region (Chapter 5). Thus, the wave may penetrate with more energy through the parts with a higher water level on the edge because of the refraction process. Furthermore, at high tide, the water level in Barretão passage increases, which reduces the energy dissipation by bottom friction during the propagation of waves in the channel.

In addition to the open ocean swell reduced at the reef crest, the component of the wave energy that crosses the reef flat and the lagoon propagates to the lagoon and reaches the reef island shore on Rocas (Farol and Cemitério islands). The residual energy that follows wave breaking and energy dissipation becomes the incident energy that is instrumental in causing island beach change (Kench et al., 2006). However, the tidal modulation of wave energy limits the amount of time that geomorphic work can occur on reefs (Kench et al., 2006). Direct sediment remobilization by waves can only occur at high tide, when more energetic waves penetrate the lagoon and the water level involves the beach side boundaries of Farol and Cemitério Islands. At low tide, the waves remain virtually constant at a height of $0.2 \mathrm{~m}$, regardless of offshore conditions; the vicinity of the islands is exposed, and the submerged area of the lagoon is reduced. 
The effect of waves is therefore limited both in area and magnitude throughout a tidal cycle.

However, even when the wave energy level in the lagoon is greatly reduced because of the tide level, due to wave breaking and set-up, water volumes are continuously pumped into the atoll, which is an important mechanism of circulation into the atoll (Chapter 3). Wave pumping is one of the main drivers that generates mean wavedriven currents across reef systems and controls ocean-lagoon flow in atolls (Callaghan et al., 2006; Hench et al., 2008; Lowe et al., 2009b).

\subsubsection{Extreme events}

As noted above, Rocas has a mild wave climate throughout the year because of its geographic position on the western edge of the South Atlantic, near the equator. The results show that extreme wave events are mainly related to the energy dissipation process of swell (groups 2 and 3 ) incident on the shallow waters of the atoll and that the tide plays a key role in selecting which energetic offshore events may reach the interior of the atoll.

Because of the tidal effect on the dissipation process, the extreme offshore conditions observed do not necessarily cause extreme conditions in the lagoon. Extreme events in Pacific and Indian atolls, located outside the tropical cyclone belt, have been associated with the dissipation of wind waves generated by distant extra-tropical cyclones (swell), especially if they occur during high tides (Hoeke et al., 2013a). However, because Rocas is a mesotidal atoll, not only high tides but also high tides during a spring tide regime are necessary to generate extreme events inside the lagoon. This fact is mainly observed in extreme offshore events that occur in combination with neap high tides and do not result in extreme events in the lagoon. In Rocas, spring and neap tide cycles alternate every 15 days on average, and the variation between high tides may reach $1 \mathrm{~m}$, generating considerable variations in water level and height in relation to the atoll rim, which may significantly limit the transmission of energy into the atoll.

High-energy waves breaking on the reef rim can cause locally extreme sea levels and currents that, during high tides, may lead to inundation (Aucan et al., 2012) and/or great morphological changes in the reefs and reef islands (Smithers and Hoeke, 2014). Inundation of near-equatorial (between $5^{\circ} \mathrm{N}$ and $5^{\circ} \mathrm{S}$ ) low lying islands, severe in some cases, has been documented throughout the Pacific Ocean and in the Indian Ocean by swell-driven sea level anomalies that add to high tides (Caldwell et al 2009; Harangozo 1992; Hoeke 2009; Oxfam 2009; White 2008).

In Rocas, flood events have been observed periodically. However, no recorded data on the severity and extent of these floods exist. Two recent cases were informally 
recorded by the environmental agency managing the atoll (the Chico Mendes Institute of Biodiversity Conservation Biological Reserve Rocas Atoll Biological Reserve - ICMBio REBIO Atol das Rocas) during the course of this study. Extreme events coinciding with spring high tides may be the main causes of the reported floods. Furthermore, high wave set-up is generally accompanied by high wave run-up, energetic near-shore currents, and possibly complex nonlinear effects such as infra-gravity waves, all of which may greatly exacerbate inundation and morphological changes in reef islands (Hoeke et al., 2013a).

The swell incidence direction may also affect the energy distribution throughout the atoll (Kench et al., 2006) and cause large reversals in sediment flux and significant changes in atoll island shorelines (Kench and Brander, 2006a). In Rocas, the results do not indicate a predominant direction of extreme events, that is, the swell generated both in the Northern and Southern Hemispheres contributed equally to the incidence of potential extreme events on the atoll. However, the more energetic conditions of the lagoon are mainly related to the north swell incidence combined with the spring tide. This finding may be explained by the atoll morphology itself. Because the main passage (Barretão) faces the north, the waves derived from this direction may propagate to the lagoon with lower dissipation. Conversely, the waves generated in the Southern Hemisphere experience great reduction in the windward rim and manage to penetrate through the channel after undergoing refraction.

Extreme events from the north may also more directly impact the reef islands because of their position in the northwestern part of the atoll, only a few meters from the reef edge, and their proximity to Barretão passage. Furthermore, the reef crest on this side is lower than the crest on the exposed side (Chapter 5). Thus, the water level at high tide is deeper on this side, allowing further propagation of the reformed waves. Conversely, extreme events that directly affect the southeastern edge of the atoll (windward) may contribute to the detachment and remobilization of coarse fractions of the reef and the availability of sediments for deposition on the side of the islands facing the lagoon (Gourlay, 1988). Although the occurrence of these extreme events presents longer recurrence ranges and short durations (only few hours), it may initiate a change that lasts several years until a new stable situation develops (Gourlay, 1988). 


\section{Chapter 3}

\section{WAVE AND TIDAL FLUSHING ON ROCAS ATOLL}

\subsection{Introduction}

Atolls are mid-ocean reefs with an annular reef rim, enclosing a lagoon (Barry et al. 2007). Their general saucer-shape lagoon morphology can be completely closed by a continuous emerged rim, or open to the ocean by continuously submerged reef flats (Dumas et al. 2012). In addition, the reef rim may present a number of passages that connect lagoon and ocean (Andréfouët et al. 2001) and act as conduits of water and sediments (Kench \& McLean 2004).

Exchange of water between the lagoon and the surrounding ocean determines biological (Tartinville et al. 1997) and geological processes occurring inside the atoll. The rate of water exchange often controls the availability of nutrients and oceanic plankton biomass to reef communities (Dufour \& Berland 1999; Le Borgne et al. 1997), influences the transport, dispersal, and retention of larval fish, corals, and other invertebrates to the lagoon (Dight et al. 1990; Black 1993), and represents cross-reef currents that help in maintaining high levels of nutrient uptake by reef flat organisms (Hearn et al. 2001). Moreover, these currents are able to transport allochthonous reefderived sediment that contributes to lagoon infill (Kench \& McLean 2004) and reef islands formations (Kench \& Brander 2006).

In general, tides and waves have been identified as the primary driving mechanisms of lagoon circulation and flushing of atoll lagoon systems. Their relative importance depends on the topography of the atoll rim as well as on the local wave and tide climates (Callaghan et al. 2006). The degree to which the lagoon of an atoll is enclosed and the nature of the passages are key features in relation to the circulation and flushing of the lagoon (Woodroffe \& Biribo 2011). Atolls with numerous or large passages are generally effectively flushed by tidal circulation, whereas atolls that have almost continuous reef rims around their perimeter are more likely to be flushed through wave-action over the top of the reef rim (Callaghan et al. 2006). Because these factors are specific to local wave and tidal conditions, and atoll morphology, atoll lagoons have widely varying flushing characteristics (Atkinson et al. 1981).

There have been a number of studies investigating flushing and circulation of different types of atolls such as open atolls (von Arx 1948); (Atkinson et al. 1981; Tartinville et al. 1997; Beach et al. 2000; Kraines et al. 1999), semi-closed atolls (Gallagher et al. 1971; Dumas et al. 2012; Kench 1998; Kench \& McLean 2004), and fully closed atolls 
(Callaghan et al. 2006; Sugandika et al. 2014), however, most are subjected to microtidal regimes. There have been limited investigations of the relative importance of waves and tides on ocean-lagoon water exchange at mesotidal atolls, where the water level range can exceed $2.5 \mathrm{~m}$. The objective of this study was to assess the contribution of tides and waves to the lagoon flushing of Rocas Atoll, a mesotidal South-Atlantic atoll with an almost unbroken rim. This is the first study of the hydrodynamic characteristics of Rocas Atoll.

\subsection{Methods}

\subsubsection{Measurements of waves, currents and water level}

Currents, tides and wave measurements were obtained during two expeditions to Rocas Atoll: in June - July2013 and in December 2013. Access to the Rocas Atoll is difficult and any survey conducted there requires the license of the Chico Mendes Institute (ICMBio - Brazilian Ministry of the Environment). Synchronous bottommounted acoustic Doppler current profilers (ADCP) were deployed at the two reef passages, inside the atoll's lagoon and offshore of the atoll (Figure 3.1). All ADCPs were $1 \mathrm{MHz}$ Nortek Aquadopps.

The strategy for data acquisition was to measure incident waves on the windward rim, water levels and currents inside and outside the lagoon and through both reef passages (Table 3.1). On the first deployment, waves, currents and water level oscillations (F1) were measured by an offshore ADCP mounted $0.5 \mathrm{~m}$ above the

bottom at $16 \mathrm{~m}$ depth. Wave measurements were the average of $1 \mathrm{~min}$-long acquisition at $2 \mathrm{~Hz}$ and stored every 1 hour using burst lengths of 2048 samples (17.1 $\min$ ) at $2 \mathrm{~Hz}$. During the same period, currents and water level were measured inside the lagoon (F2) and at the larger reef passage (F3). The data collection settings were the same as for the offshore ADCP. The second expedition (December 2013) was designed to obtain synoptic water level and current measurements only at the larger (S1, Barretão) and smaller (S2, Barretinha) reef passages for nearly 1 week. Current records at all sites represented 2-minute averages taken at 10-minute intervals.

Directional wave characteristics were calculated by standard PUV methods (Nortek, 2002) using the measured dynamic pressure $(P)$ and orbital velocities ( $U$ and $V$ ) from the ADCP. Tide harmonic analysis was performed with the T_tide toolbox (Pawlowicz et al. 2002). Current velocity of the larger passage (Barretão) was low pass-filtered to remove the semidiurnal tide signal in the data in order to assess the effect of waves on the residual velocities. 

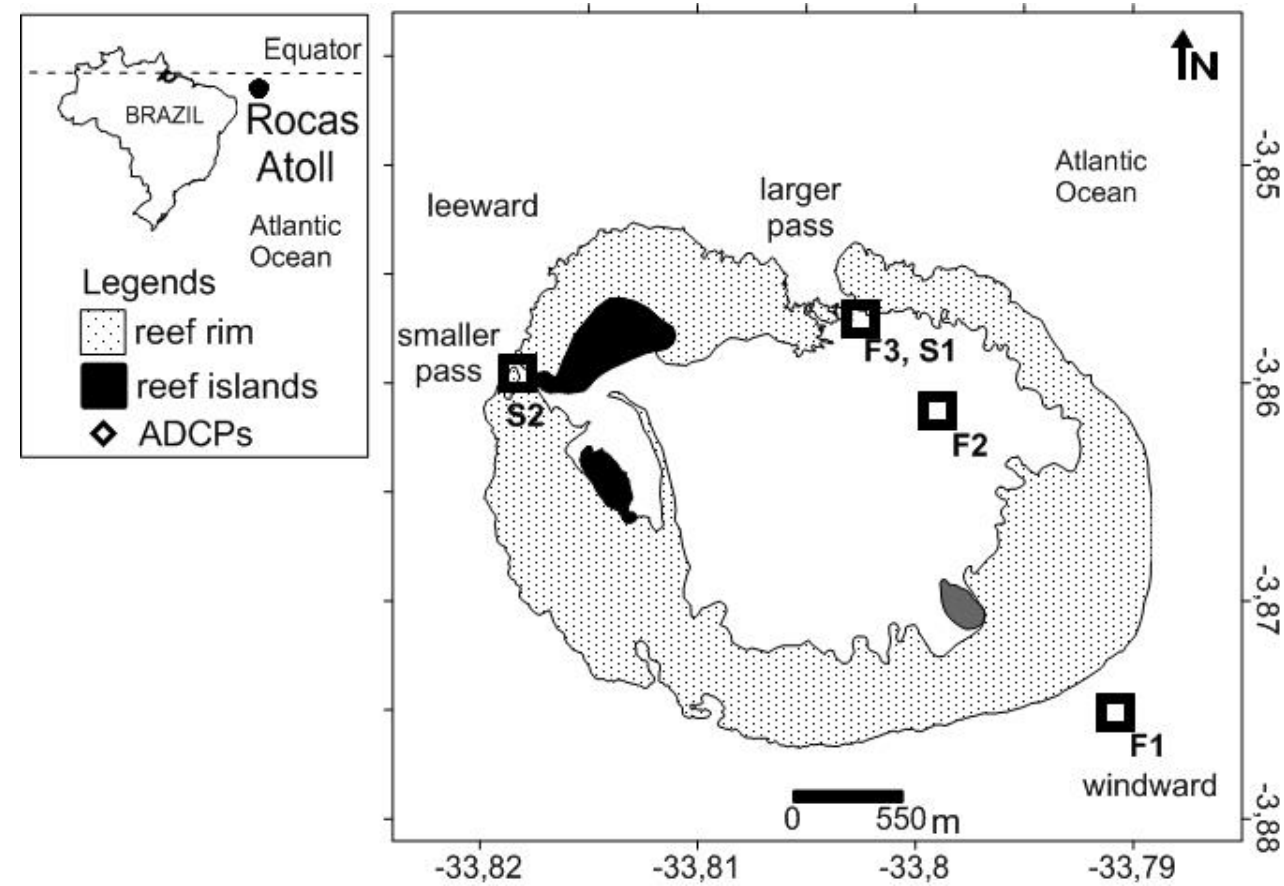

Figure 3.1. The Rocas Atoll. Mooring locations indicated by black squares.

Table 3.1. Instruments deployment information. Their position is shown in Fig 1.

\begin{tabular}{cccccc}
\hline Expedition & Mooring station & Depth & Instrument & Deployment & Duration \\
\hline 1 & Southeast (F1) & $16 \mathrm{~m}$ & $A D C P 1 M H z$ & $29 \mathrm{Jun}-27 \mathrm{Jul}(2013)$ & 28 days \\
1 & Lagoon (F2) & $2 \mathrm{~m}$ & $A D C P 2 \mathrm{MHz}$ & $01 \mathrm{Jul}-21 \mathrm{Jul}(2013)$ & 20 days \\
1 & Larger passage (F3) & $5 \mathrm{~m}$ & $A D C P 1 \mathrm{MHz}$ & $04 \mathrm{Jul}-20 \mathrm{Jul}(2013)$ & 16 days \\
2 & Larger passage (S1) & $5 \mathrm{~m}$ & $\mathrm{ADCP} 1 \mathrm{MHz}$ & $12 \mathrm{Dec}-16 \mathrm{Dec}(2013)$ & 4 days \\
2 & Smaller passage (S2) & $3 \mathrm{~m}$ & $\mathrm{ADCP} 2 \mathrm{MHz}$ & 07 Dec-15 Dec (2013) & 8 days \\
\hline
\end{tabular}

\subsection{Results}

\subsubsection{Tides}

Harmonic analysis of water level showed that tides were dominated by the semidiurnal M2 and S2 constituents at both enclosed and open waters of the atoll (Table 3.2). The amplitude ratio between the main diurnal and semi-diurnal constituents $[\mathrm{F}=(\mathrm{K} 1+\mathrm{O} 1) /(\mathrm{M} 2+\mathrm{S} 2)]$ was less than 0.1 for all locations, which described tides as semidiurnal with almost no inequalities in the range and time between successive high and low tides. The M4 and MS4 constituents were more prominent at shallow water stations (lagoon and reef passages) than outside the atoll (Table 3.2). This increase of overtides in the lagoon reflects the relevance of shallow water processes on tidal variations. 
All stations showed similar ranges in water level oscillations (Figure 3.2). The maximum observed tidal range was $2.8 \mathrm{~m}$ with a mean high spring water (MHSW) of $2.4 \mathrm{~m}$ and a mean low spring water (MLSW) of $0.3 \mathrm{~m}$. During neap tides, the maximum observed tidal range was $1.7 \mathrm{~m}$ with a mean high neap water (MHNW) of $2.0 \mathrm{~m}$ and a mean low neap water (MLNW) of $0.9 \mathrm{~m}$. The difference between water level at spring and neap tides can be up to $1 \mathrm{~m}$ for both high and low tides.

Comparison of water level records identified a phase lag between the large and small reef passages (Figure 3.2b). The peak cross correlation ( $r=0.98)$ was obtained at a delay of one 10-minute sample interval, with tides in the large passage occurring up to 30 min after those in the small passage, and approximately 14 minutes on average. The lag was smaller at high tide. A smaller phase lag of $10 \mathrm{~min}$ on average was encountered between the open water station and the larger reef passage ( $r=0.99)$ (Figure 3.2a).

Table 3.2. Tidal harmonic constituents based on water level records at open ocean (Station ES2), lagoon (Station IL2) and the larger reef passage (Station IBO2).

\begin{tabular}{ccccc}
\hline $\begin{array}{c}\text { Harmonic } \\
\text { constituent }\end{array}$ & Period (h) & $\begin{array}{c}\text { Ocean } \\
\text { amplitude (cm) }\end{array}$ & $\begin{array}{c}\text { Lagoon } \\
\text { amplitude }(\mathrm{cm})\end{array}$ & $\begin{array}{c}\text { Reef pass } \\
\text { amplitude }(\mathrm{cm})\end{array}$ \\
\hline MSF & 354.37 & 1.30 & 4.00 & 0.96 \\
O1 & 25.82 & 4.14 & 6.39 & 4.11 \\
K1 & 23.93 & 6.54 & 1.68 & 7.17 \\
M2 & 12.42 & 83.14 & 83.87 & 85.37 \\
S2 & 12.00 & 24.62 & 25.52 & 25.32 \\
M4 & 6.21 & 0.55 & 5.31 & 3.72 \\
MS4 & 6.10 & 0.16 & 3.10 & 2.10 \\
\hline
\end{tabular}
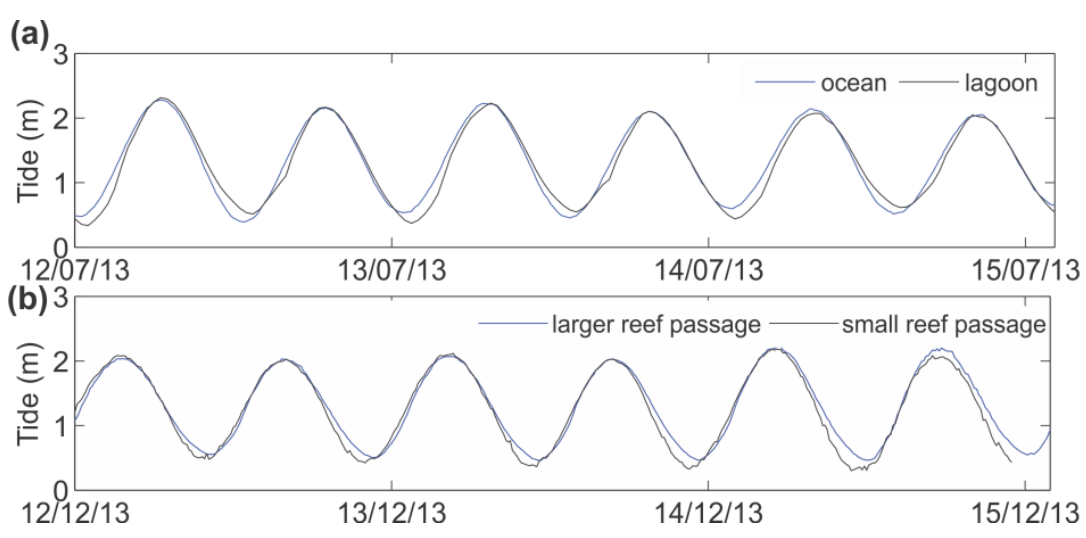

Figure 3.2. Water level oscillation samples for (a) ocean (station ES2) and lagoon (IL2) during the second leg (July 2013) and for (b) the reef passages (stations IBO3 and IBA3) during the second campaign (December 2013). 


\subsubsection{Currents}

Current meter records indicated different patterns of direction and speeds across the atoll (Figure 3.3). Currents showed higher directional variability outside the atoll, however they were predominantly southwestward. The velocity varied with the tidal cycle, especially during spring tides, and was greatest during the falling tide. The maximum speed was $0.78 \mathrm{~m} . \mathrm{s}^{-1}$ (F1) with a mean of $0.22 \mathrm{~m} . \mathrm{s}^{-1}$ (Figure 3.4a).

The currents in the lagoon (F2) exhibited the weakest speeds, with a mean of $0.16 \mathrm{~m} . \mathrm{s}^{-}$ ${ }^{1}$ and a maximum of $0.41 \mathrm{~m} \cdot \mathrm{s}^{-1}$. The flow had mainly a westward component and was greatest when it was northwestward (out of the lagoon), i.e., during falling tides. Upon reaching low tides, speeds approached zero and the direction turned southwestward (Figure 3.4b).

The larger reef Barretão passage (F3) displayed a bimodal directional structure controlled by the tidal stage. The currents were predominantly northwestward (outflow), but they reverted southeastward (inflow) as soon as the tide reached its lowest level and started rising (Figure 3.4c). Inflow persisted only for approximately $3 \mathrm{~h}$ 50 min of the rising tide ( $27 \%$ of a tidal cycle). Nearly in the middle of this rising tide, at water levels of $\sim 1.6 \mathrm{~m}$, the flow reverted again oceanward (northwestward) and the outflow persisted for the remainder of the tidal cycle. This tidal reversal pattern could be observed over the entire sampling period and the reversal occurred in less than ten minutes. The reversal to outflow developed when the rising tide overtopped the atoll's rim, all around the atoll. The only escape of this volume of water in the lagoon was the larger inlet, producing outflow there. Maximum outflow velocities occurred during the falling tide, reaching up to $1.5 \mathrm{~m} . \mathrm{s}^{-1}$. At low tides, the outflow speeds sharply decreased to $0.1 \mathrm{~m} . \mathrm{s}^{-1}$, with inflow peaks of $1.0 \mathrm{~m} . \mathrm{s}^{-1}$ at $\sim 3 \mathrm{~h}$ after low tide (Figure 3.4c and Figure 3.5a).

In the smaller Barretinha passage (S2), currents were mostly northwestward (outflow) and showed tidal modulation in direction (Figure 3.5b). The direction became westward and southwestward in the falling tide, as the level approached low tide. However, in contrast to Barretão passage, there was no total flow reversal. Comparison of synchronous current time series records from Barretão and Barretinha passages showed that the currents at the smaller Barretinha passage remained slow (aprox. $0.1 \mathrm{~m} . \mathrm{s}^{-1}$ ) during inflows at Barretão passage. Outflows at Barretinha systematically increased $\sim 20 \mathrm{~min}$ after outflow began in the larger reef passage, reaching up to $0.8 \mathrm{~m} . \mathrm{s}^{-1}$ at high tide (Figure $3.5 \mathrm{~b}$ ). These relatively large outflows during high tide were also related to the tides overtopping the rim and the inlets becoming the unclogging pathways in the lagoon. 

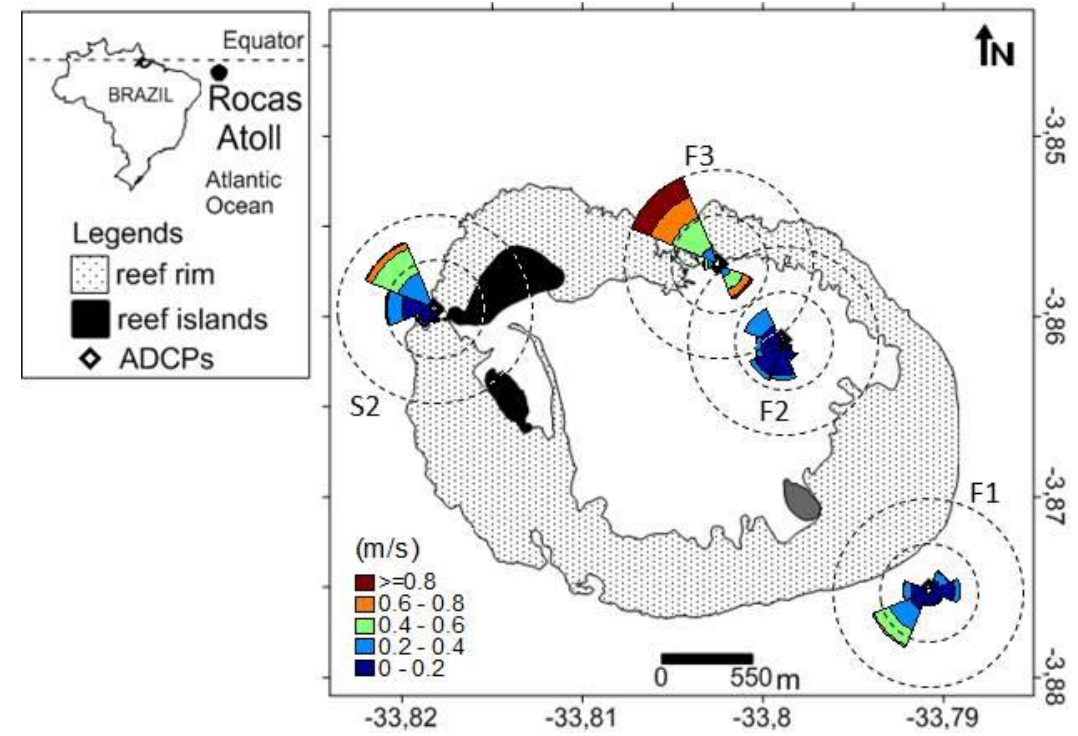

Figure 3.3. Directional histograms of measured flows (m.s-1).
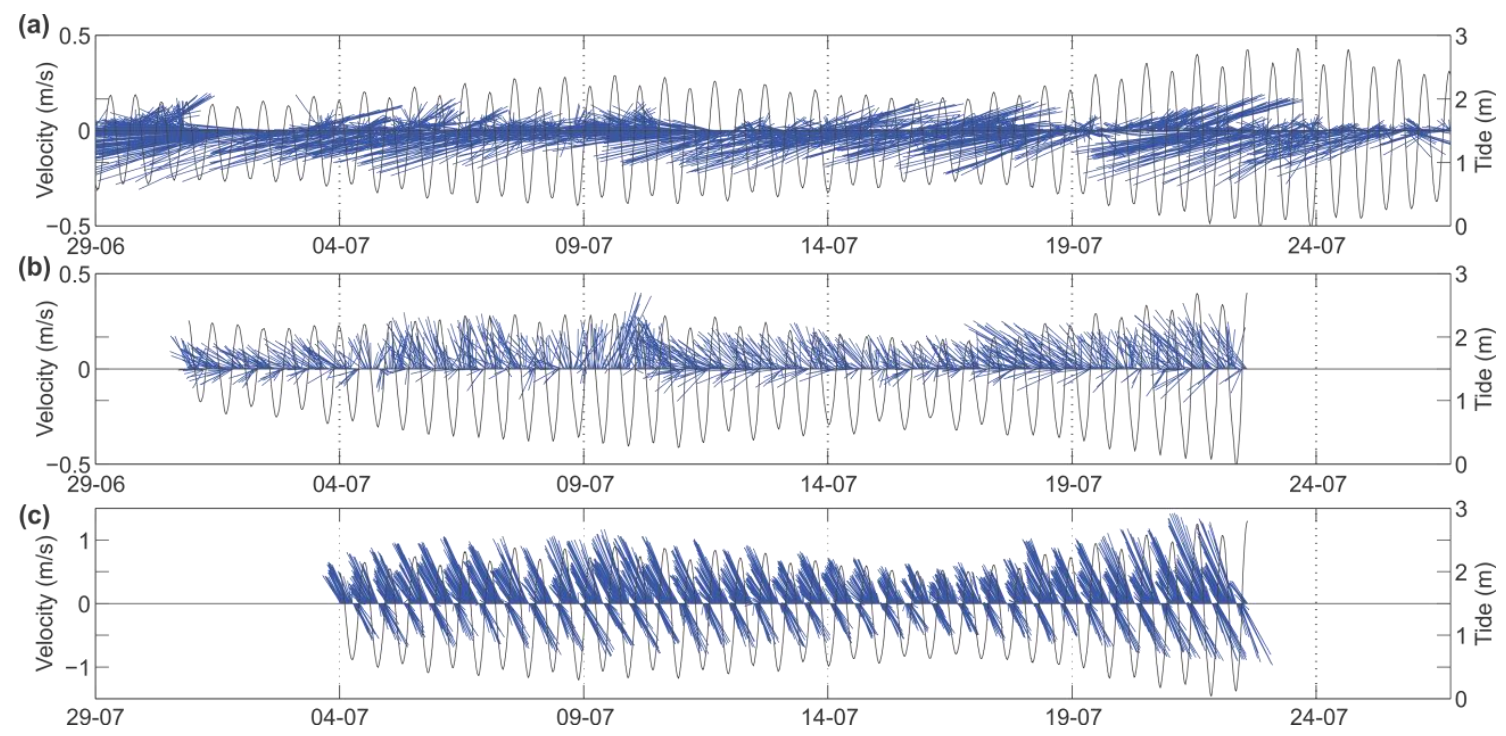

Figure 3.4. Synchronous water elevation and current vectors at (a) southeast (F1) of the atoll, (b) lagoon (F2) and (c) larger (F3) reef passages during first expedition (July 2013).

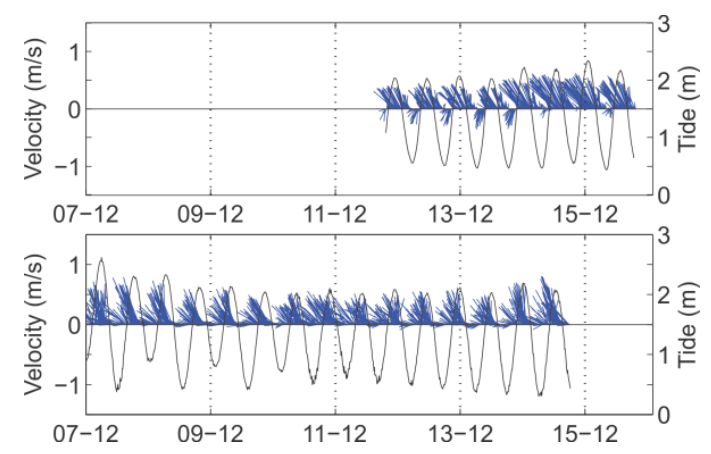

Figure 3.5. Synchronous water elevation and current vectors at the (a) larger (S1) and smaller (S2) reef passages during second expedition (December 2013). 


\subsubsection{Water exchanges through the passes}

The volume transport through the passages was estimated using the ADCP current profiles and a cross-channel bathymetric profile (Table 3.3). Average inflow and outflow transports at the larger reef passage were $104.3 \mathrm{~m}^{3} . \mathrm{s}^{-1}$ and $128.8 \mathrm{~m}^{3} . \mathrm{s}^{-1}$, respectively. Despite being similar in magnitude, there was a marked asymmetry between their duration in a tidal cycle. Outflows accounted for $73 \%$ of the tidal cycle duration, which corresponds to water outflow during approximately $9 \mathrm{~h} 04 \mathrm{~min}$ at each tidal cycle. This result in a substantial difference in total water volume exchanged through these passages. Volume estimates using flow rates related to inflow and outflow duration gave a total inflow volume of $1.26 \times 10^{6} \mathrm{~m}^{3}$ per tidal cycle, whereas the total outflow volume was $4.20 \times 10^{6} \mathrm{~m}^{3}$ per tidal cycle, i.e., 3.33 times higher.

At the smaller reef pass, outflow persisted for $97 \%$ of the tidal cycle with an average discharge of approximately $34.2 \mathrm{~m}^{3} . \mathrm{s}^{-1}$. The average inflow rate is $12 . \mathrm{m}^{3} . \mathrm{s}^{-1}$ and starts after low tide. However it does not contribute to the lagoon water volume because this passage becomes disconnected from the main lagoon during low tides due to emerged sandbars,. Once this water volume enters the system at low tide, it contributes only to a small water volume near the entrance. The total volume that leaves the lagoon through this passage is estimated to be $1.48 \times 10^{6} \mathrm{~m}^{3}$ per tidal cycle.

Table 3.3. Mean water flow estimates through the reef passes.

\begin{tabular}{ccccc}
\hline Reef passages & $\begin{array}{c}\text { Current velocity } \\
\left(\mathrm{m}^{-1}\right)\end{array}$ & $\begin{array}{c}\text { Flow rate } \\
\left(\mathrm{m}^{3} . \mathrm{s}^{-1}\right)\end{array}$ & $\begin{array}{c}\text { Duration per tidal } \\
\text { cycle }(\mathrm{h})\end{array}$ & $\begin{array}{c}\text { Total Volume }\left(\mathrm{m}^{3}\right) \\
\text { per tidal cycle }\end{array}$ \\
\hline $\begin{array}{c}\text { Larger passage } \\
\text { Inflow }\end{array}$ & 0.47 & 104.34 & $3.35(27 \%)$ & $1.26 \times 10^{6}$ \\
$\quad$ Outflow & 0.58 & 128.76 & $9.07(73 \%)$ & $4.2 \times 10^{6}$ \\
Smaller passage & & & $0.37(3 \%)$ & $0.17 \times 10^{6}$ \\
$\quad$ Inflow & 0.12 & 12.97 & $12.05(97 \%)$ & $1.48 \times 10^{6}$ \\
Outflow & 0.31 & 34.23 & &
\end{tabular}

\subsubsection{Waves, current at larger reef pass, and lagoon water level}

Typical trade wind wave conditions $(0.333-0.125 \mathrm{~Hz})$ were observed at offshore Rocas Atoll (station F1) with significant wave heights in the $0.5 \mathrm{~m}-1.5 \mathrm{~m}$ range and some energetic events reaching up to $2.5 \mathrm{~m}$ (Figure 3.6a). Peak wave periods ranged from $5 \mathrm{~s}$ to $19 \mathrm{~s}$ (Figure 3.6b). These waves approach the atoll mainly from the SE. Swell generated at higher southern latitudes $(0.125-0.05 \mathrm{~Hz})$ were also observed for a short period during the first days of measurements, with peak periods between $13 \mathrm{~s}$ and $19 \mathrm{~s}$. However, the wave energy spectrum is dominated by wind wave frequencies Figure 3.6c). Residual current velocities (de-tided) measured in the larger reef passage 
during the same period showed good correlation ( $r=0.71)$ with the incoming significant wave height observed at station F1. The strongest residual velocities were observed (values up to $0.80 \mathrm{~m} . \mathrm{s}^{-1}$ ) when significant wave heights were higher than $1.5 \mathrm{~m}$ (Figure 3.6d). This was consistent with wave-driven circulation in fringing reef lagoons (e.g., Coronado et al., 2008).

Wave energy observed at the lagoon was at least one order of magnitude lower than offshore wave energy (Figure 3.6g). Significant wave height and peak wave period are strongly modulated by tides, with maximum values during high tides (Figure 3.6e, f). During low tides $\mathrm{Hs}$ are nearly zero and peak wave period is about $5 \mathrm{~s}$. Maximum significant wave height was only $0.8 \mathrm{~m}$ observed during a spring high tide. The lagoon wave spectrum is dominated by both infragravity wave energy (>0.05 Hz) and wind wave energy $(0.333-0.125 \mathrm{~Hz})$ during high tides. A marked increase of energy was observed during spring tides at both frequencies. A peak in the infragravity frequency was observed when high offshore wave energy coincided with spring high tide (Figure $3.6 \mathrm{~g})$.

The absolute water level at Barretão passage was also compared to the ocean tide to represent lagoon set-up. To establish a datum, we assumed that the water level difference is zero at the moment of flow reversion, when the current velocity is close to zero. The mean was removed from each dataset, and afterwards the data sets were aligned by shifting the open water level dataset forward by one sample interval so that the larger reef passage at $t$ was plotted against the open water level at $t+1$ intervals. Both datasets were then adjusted by a constant offset obtained from the difference of water elevation at flow reversion moments. Therefore, the absolute water level at both locations was identical for a moment during low tide (Figure 3.7). Water level was higher in the lagoon except for each first half of the rising tide (gray boxes in Figure 3.7), which corresponded to inflow to the larger reef passage. The maximum differences were largest during falling tides, reaching up to $20 \mathrm{~cm}$. 

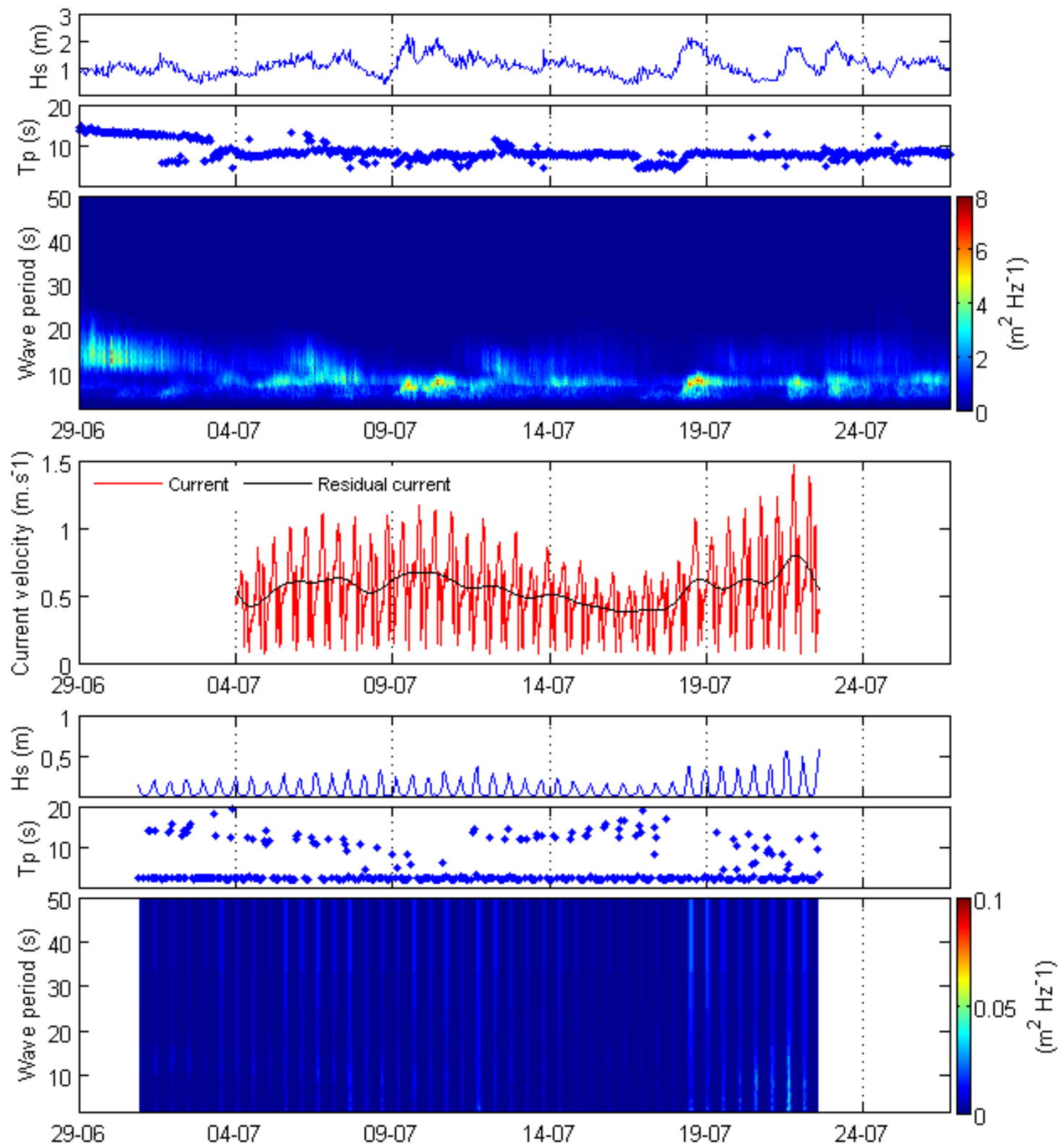

Figure 3.6. (a) Observed incident significant wave height $(\mathrm{m})$, (b) peak period $(\mathrm{s})$ and $(\mathrm{c})$ wave energy spectra ( $\mathrm{m} 2 \mathrm{~Hz}^{-1}$ ) at offshore (station $\left.\mathrm{F} 1\right)$. (d) Instantaneous and tidally filtered currents in the larger reef pass (station F3). (e) Observed incident significant wave height ( $\mathrm{m}$ ) (f), peak period (s) and (g) wave energy spectra $\left(\mathrm{m} 2 ~ H z^{-1}\right)$ at the lagoon (station F2). 

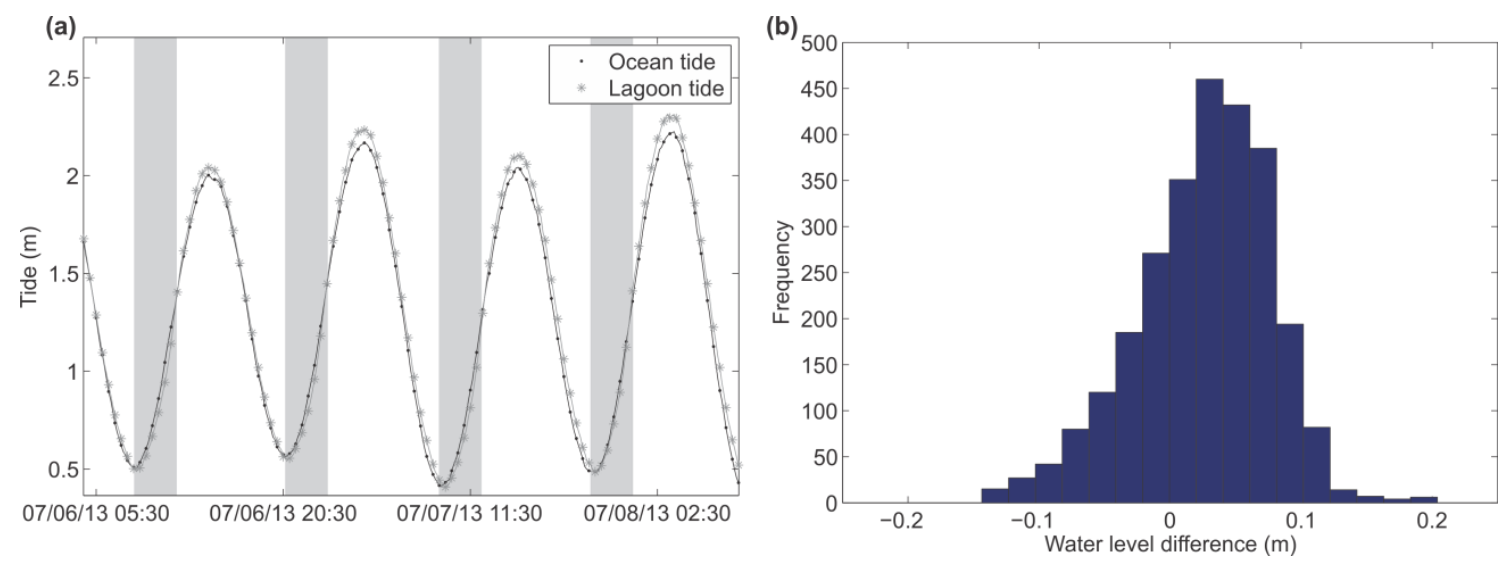

Figure 3.7. (a) Comparison of water level records inside (station IBO2) and outside (station ES2) the lagoon. Note the lower water levels in the lagoon at every first half of rising tides (gray boxes). (b) Histogram of the water level difference between lagoon and ocean.

\subsection{Discussion}

The results showed that the circulation mechanisms at the Rocas Atoll are related to tides and waves, and controlled by the water level height relative to the atoll rim elevation. In particular, the exposure of the reef rim during water level oscillations $>2$ $m$ delays the lagoon flushing rates. This behavior differs from that of microtidal atolls, where the water level remains near the reef rim surface during the entire tidal cycle.

\subsubsection{Atoll morphology and flow pattern}

There is a continuum of variation in atoll hydrodynamics, functioning according to atoll morphology and physical boundary conditions (Dumas et al. 2012). At larger and deep lagoon atolls, wind has been identified as the primary driver of circulation (von Arx 1948; Atkinson et al. 1981; Mathieu et al. 2002). The relative importance of tides on circulation and flushing increases as atoll dimensions and depth decrease (Kench 1998), and at smaller and shallower atolls, such as Rocas, the effects of waves and tides become more prominent.

The unique dataset collected on Rocas Atoll shows that the general current flow is westward for both inside and outside the atoll, ranging mainly from northwestward to southwestward. This direction corresponds to the wind waves and currents generated by southeasterly trade winds. Waves break on the southeastern portion (windward) of the atoll all year round. Therefore, the observed westward flow (windward to leeward) represents a typical condition of Rocas circulation, which can be, in turn, affected by the seasonal swells. Additionally, because regional ocean currents have been noted to impinge slight influence on the circulation of atoll lagoons (Kraines et al. 1999), it is possible that the South Equatorial Current could also contribute to the westward flows that were observed to dominate not only inside the lagoon but also outside of the atoll (station F1). 
Oceanic waves breaking over the reef induce an elevation of the lagoon surface water level on the windward rim, while water will drain to the ocean on the leeward side (Callaghan et al. 2006). On Rocas Atoll the lagoon water level remains higher than offshore water level for most of a tidal cycle. This is thought to be caused by wave setup on the atoll windward side also resulting in infragravity waves over the reef flat (e.g. Symonds et al., 1982; Péquignet et al., 2009; Pomeroy et al., 2012; Péquignet et al., 2014). Our results show that waves with frequency between $0.06 \mathrm{~Hz}$ and $0.05 \mathrm{~Hz}$ suffer highest dissipation by the reef rim, adding to wave set-up. Waves between the aforementioned frequencies are not significant in the lagoon spectrum. In contrast, short wind waves are able to propagate into the lagoon during high tides and dominate the lagoon spectrum together with infragravity waves. The infragravity waves can also play a role on the lagoon water level and produce resonant conditions (Torres-Freyermuth et al., 2012), especially during energetic offshore waves.

The inflow by wave pumping water into the lagoon tends to create a unidirectional flow across the atoll. However, atoll openings can also affect the flow patterns and flushing (Andréfouët et al. 2001). As demonstrated by Callanghan (2006), if the atoll has wide reef passages, which are deep compared to the wave height and tidal range, the flushing will be generated mainly by the tide, and the lagoon water level will oscillate with the range of the ocean. However, if the atoll has an almost unbroken rim of living coral growing to a few decimeters above mean sea level (MSL), the flushing will be driven by the waves (Callaghan et al. 2006). At the Rocas atoll, the flow is unidirectional at the smaller reef passage and bidirectional at the larger passage. These two passages present differences in their morphologies that may be related to the observed flow pattern. The smaller passage is narrower and shallower with depth, decreasing lagoonward and culminating in intertidal sand aprons. According to Chevalier (1972), this corresponds to an intermittent functional reef passage, which is not connected to the lagoon at all tidal stages. Thereby, soon after low tides the water enters for a very short time in a volume sufficient to fill the passage itself, and the water becomes slack near the entrance and is unable to enter in the lagoon. The outflow dominates $97 \%$ of the tidal cycle in this passage. In contrast, the larger reef passage is fully functional, i.e., it is permanently connected to the lagoon and transmits water under all tidal stages. The duration of the inflow is only approximately one quarter of each tidal cycle.

Outflow dominates both reef passages. The total outflow from the larger and smaller reef passages is approximately $162.2 \mathrm{~m}^{3} . \mathrm{s}^{-1}$, which gives a total volume of $5.69 \times 10^{6} \mathrm{~m}^{3}$ per tidal cycle. In contrast, the total inflow volume through the passages is only $1.26 \mathrm{x}$ $10^{6} \mathrm{~m}^{3}$ per tidal cycle. The strong outflow from both reef passages must be balanced by an inflow into the lagoon that, in turn, must be approximately 3.5 times higher than the total inflow volume passing through the passages. As a result, the inflow by wave 
pumping represents the main mechanism of ocean water entrance to the Rocas lagoon.

\subsubsection{Drag coefficient at the main reef passage}

Assuming that the atoll circulation is controlled by the pressure gradient induced through the wave water pumping and due to water level controls on this process, the drag coefficient $\left(C_{D}\right)$ in the main reef passage (Barretão) was estimated using a simplified momentum balance, vertically averaged, between pressure gradient and friction, which may be written as (e.g. Parra et al., 2014) :

$$
g \frac{\eta L-\eta O}{d x}=-\frac{C_{d} U^{2}}{H}
$$

where $g$ is gravity's acceleration, $\eta L$ is the water level inside the atoll, $\eta 0$ is the water level outside the atoll, $d x$ is the distance between passage and outside stations $(0.61$ $\mathrm{km}), U$ is the flow speed at the passage, and $\mathrm{H}$ is the depth of the passage. The mean drag coefficient in the passage is 0.006 . Although values vary between 0 and $0.5,98 \%$ of the values range between 0 to 0.05 (with an average of 0.005 in this class) and only $2 \%$ of the values are higher than 0.05 (Figure 3.8). Drag coefficients higher than 0.05 are observed only after the flow reversals at the passage. At these times of flow reversals, speeds are still low despite relatively high water level differences. This indicates a delay in the response of passage speeds to water level gradients because of channel roughness. The drag coefficient peaks $\left(C_{D}>0.02\right)$ are observed only after flow reversals out of the atoll (outflow) at mid flood tide. At this tidal phase, waves start to break over the atoll and pump water into the lagoon. Thereby lagoon water level rapidly becomes higher than the ocean levels, causing flow reversal at the passage. However, flows are delayed due to friction, represented by high drag coefficients from the passage roughness. 

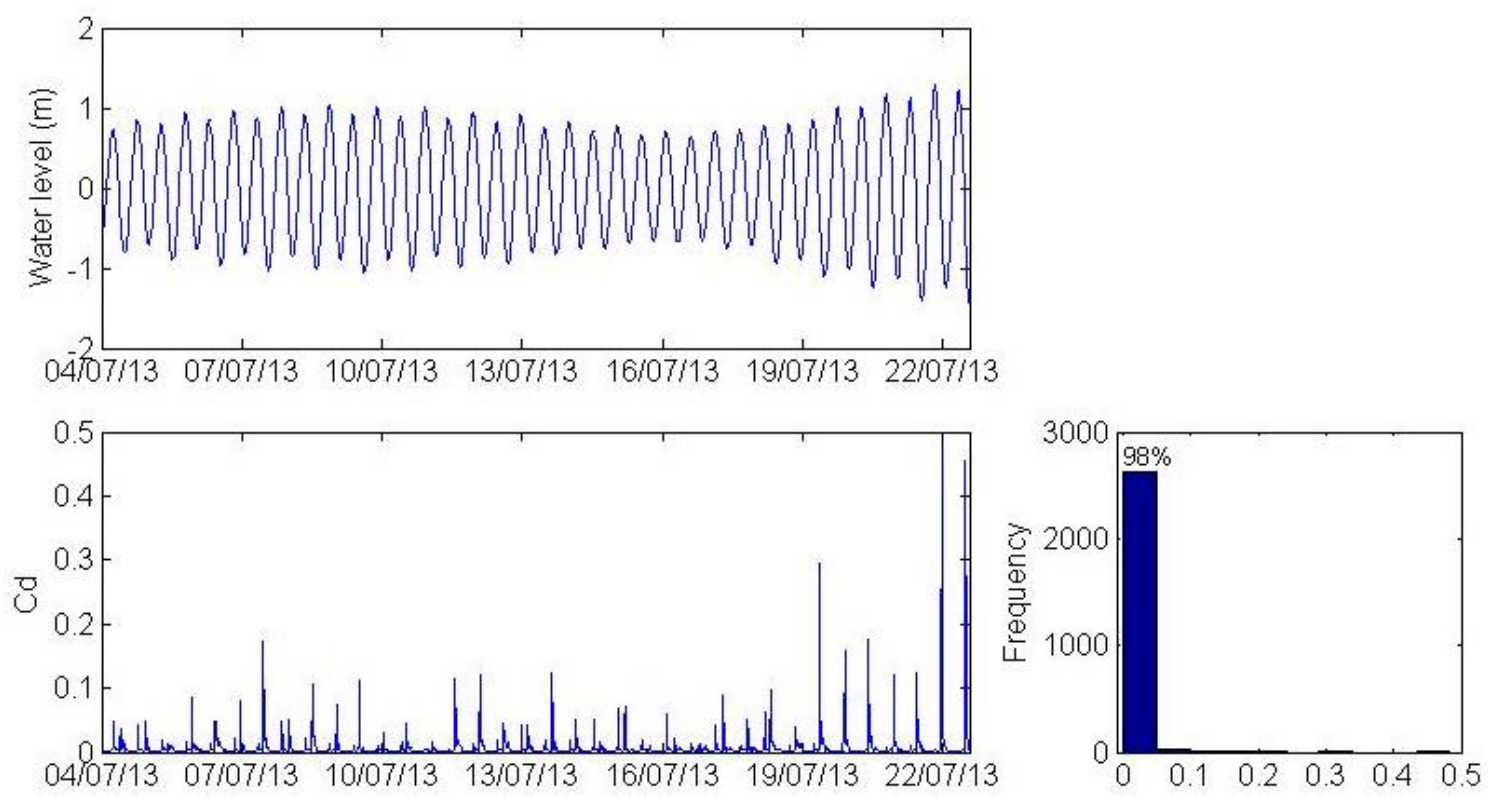

Figure 3.8. Water level (a) drag coefficient in the main channel (b) and drag coefficient values frequency distribution.

\subsubsection{Tidal influence on wave pumping}

Results show that the flow in Rocas atoll is wave-driven and modulated by tides. The residual currents in the larger passage are stronger when the offshore waves are higher, and the magnitude of instantaneous velocities varies with the tidal stage. This process is well described for many atoll lagoons and reef lagoons (Atkinson et al. 1981; Kraines et al. 1999; Kench 1998) and is crucial to understand the particular circulation mechanism of each system. However, at mesotidal atolls, the water level can drop well below the reef top, affecting the overall lagoon circulation.

Particularly at the Rocas Atoll, the inflow at the larger reef passage exhibits a very persistent pattern, starting at low tide and sharply reversing in the middle of the rising tide, specifically when the water level reaches nearly $1.6 \mathrm{~m}$ (Figure 3.9a). This reversal is related to the interaction of the water level with respect to the reef top height and wave action. Because Rocas is under a mesotidal regime, the reef top can extend up to $2 \mathrm{~m}$ above the water level at low tide. This creates an effective barrier that prevents waves from breaking onto the reef flat (Figure 3.10). Thereby, a water level threshold exists, blocking inflow by wave pumping at lower water levels. As a result, the water level differences between the ocean and lagoon start to decrease because the water continues to leave the lagoon through both reef passages and no water is added through the windward side. At low tide, water is levelled and as the tide rises, pressure gradients promote the tide-driven inflow. 
(a)

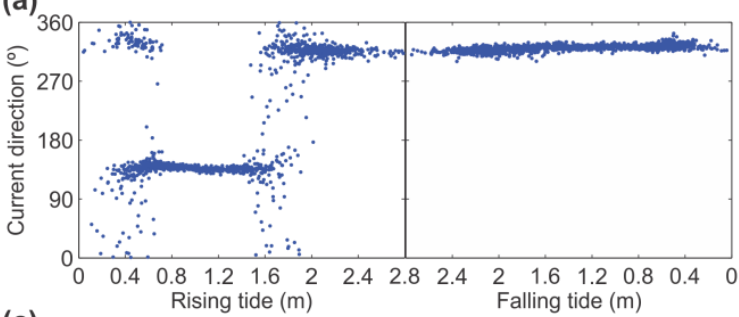

(c)

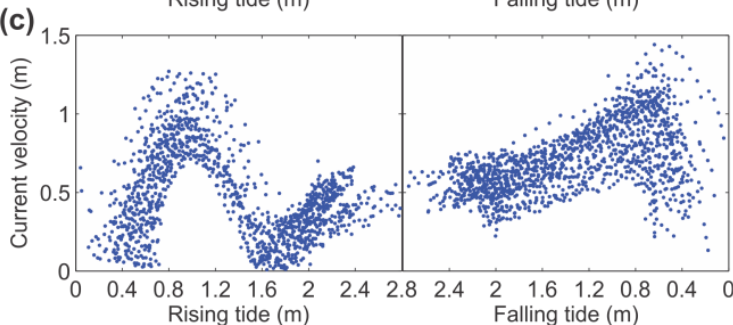

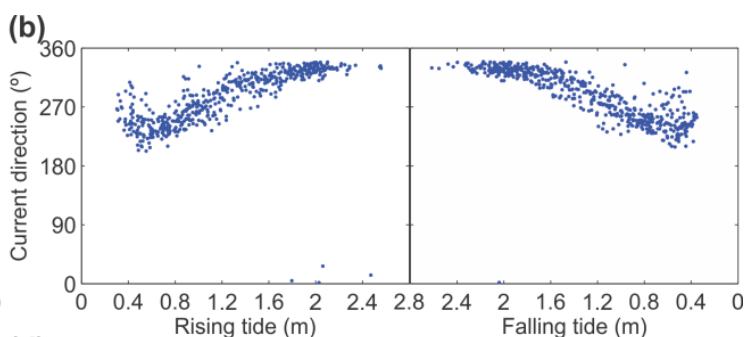

(d)

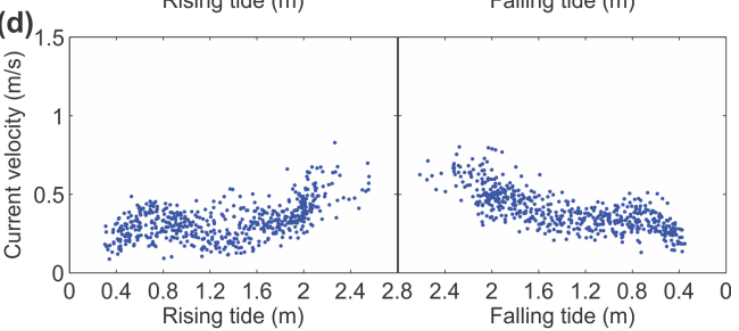

Figure 3.9. Scatter diagram of current velocity and direction over the tide level for $(a, b)$ the larger and (c,d) smaller passages.

The inflow and outflow through the larger passage also controls the magnitude and direction of lagoon currents. At the middle of the rising tide, when water level is close to the reef top surface, the wave pumping is "activated" again and the water starts to enter in the lagoon through the windward side. The water volume that enters the lagoon through the larger reef passage added to the inflow by wave pumping results in a surge in the lagoon water level, creating pressure gradients that force the water outflow. An increase in the outflow velocity at the smaller reef passage is also observed after the wave pumping process activation.

These findings allow the proposition of a conceptual circulation model for mesotidal atolls, such as the Rocas atoll. In these atolls, water level plays a fundamental role in water exchanges, not only through the pressure gradients created by water level differences but also through a threshold for hindering or allowing wave pumping. During falling tides, water enters the lagoon by wave pumping but only until reaching a water level threshold when wave pumping is blocked. During active wave pumping, lagoon water flows out through both reef passages. As tides rises after low water, ocean water flows into the lagoon through the larger reef passage up to the stage when the water reaches levels close to that of the reef rim surface (Figure 3.11). After reaching that level, tides and waves pump water into the lagoon that is flushed out through the larger passage. Results show that for mesotidal atolls, a water level threshold adds to the lagoon circulation controls. The wave pumping mechanism is switched on and off throughout a tidal cycle, resulting in periodic variations in the relative importance of tidal controls in lagoon circulation. 

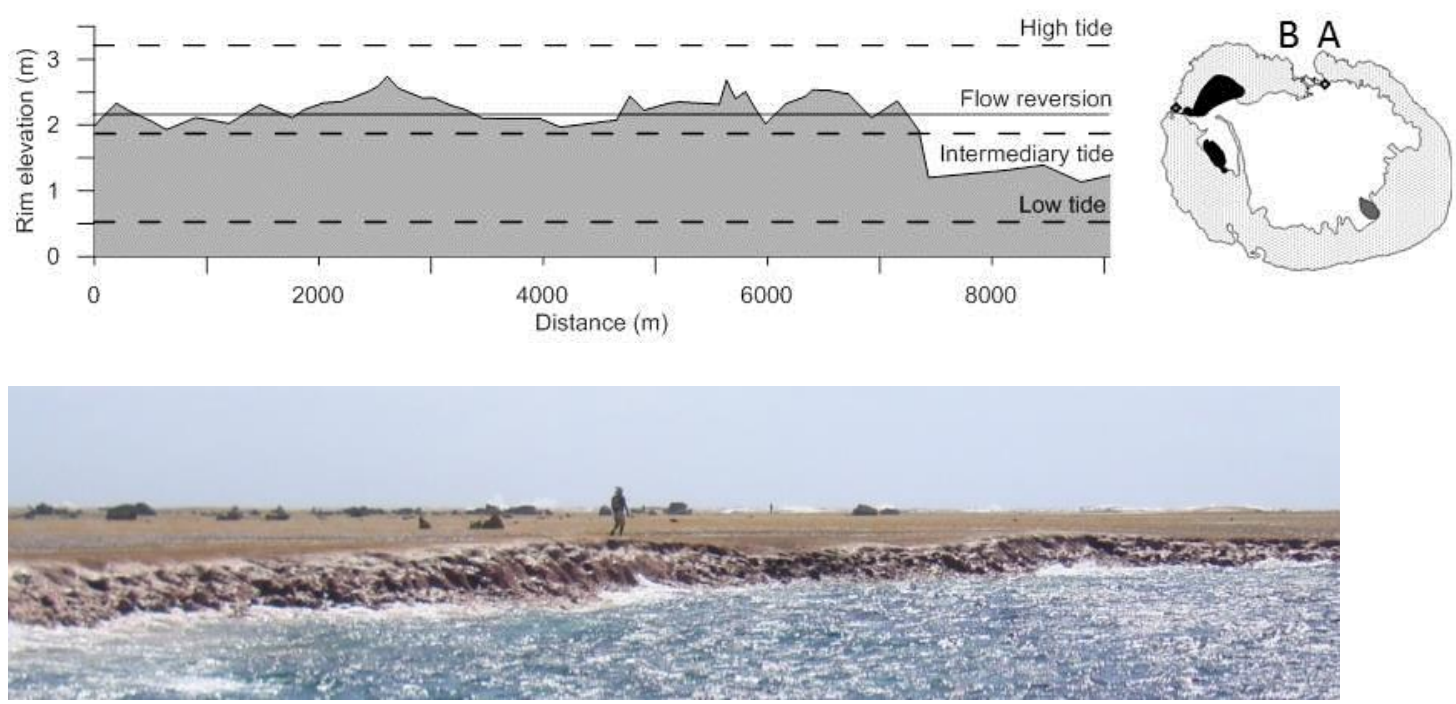

Figure 3.10. (a) Water level heights along the reef rim. Distance in meters represents the perimeter of the reef rim (clockwise from A to B). (b) Reef rim during low tides. Note that no water is flowing over the reef rim due to wave breaking at the captured tidal stage.

\section{Rising tide}
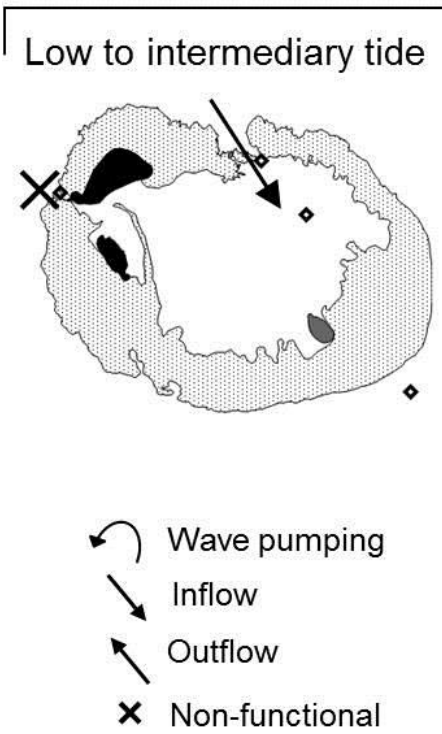

Intermediary to high tide
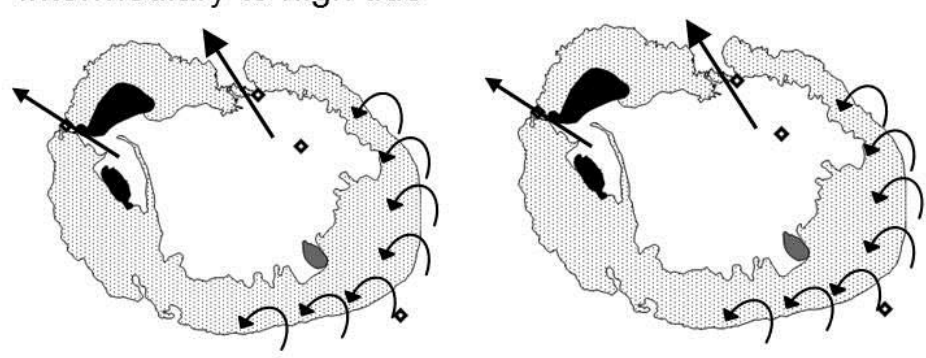

High to low tide

Falling tide
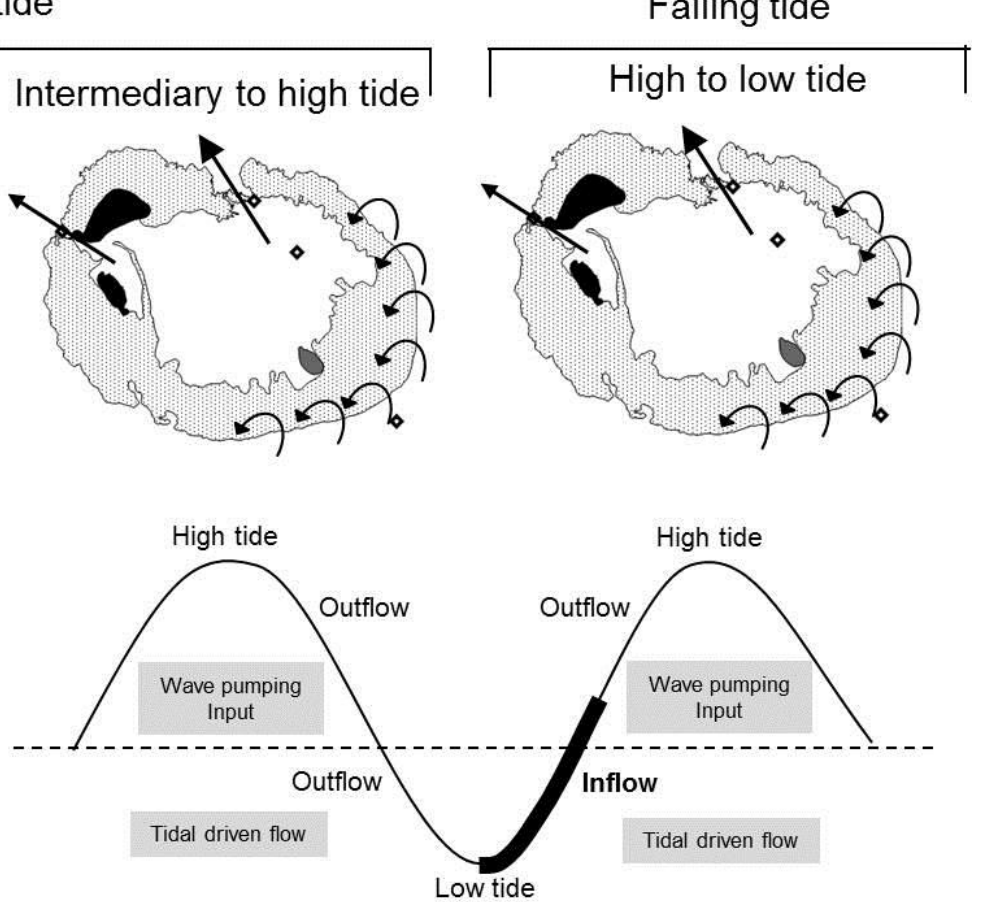

Figure 3.11. General flow model of Rocas Atoll along a tidal cycle. 


\section{Chapter 4}

\section{REEF ISLANDS MORPHODYNAMICS ON ROCAS ATOLL}

\subsection{Introduction}

Reef islands are recent geological formations (Holocene) composed by unconsolidated carbonate sediments (Hart and Kench, 2006; Woodroffe et al., 1999) deposited on the rim of atolls and platforms reefs (Yamano et al., 2005). They are typically low in elevation ( $<3 \mathrm{~m}$ above mean sea level), small in area, have a vegetated core and a narrow beach that surrounds the entire perimeter of the island (Kench and Brander, 2006a). Although their shape can vary considerably from elongate linear islands to small almost circular islands (Woodroffe et al., 1999), they share similar cross-section morphology, with a prominent oceanward beach ridge and a more subdued lagoonward beach ridge. Variations in cross section include the presence of an intertidal interior central depression in some cases, or multiples ridges between the oceanward and lagoonward ridge (Woodroffe and Mclean, 1994).

Waves represent the main process that build such islands (Woodroffe and Biribo, 2011). The carbonate sediment produced by the growth of reef organisms (Woodroffe and Biribo, 2011) is transported from areas of high wave energy to areas of low wave energy (Beetham and Kench, 2014). These areas of low wave energy, prone to sediment accumulation and island formation, are thought to be a consequence of wave refraction and diffraction on the reef top, which creates zones of wave convergence or nodal points (Flood, 1986; Gourlay, 1988; Kench and Brander, 2006a; Mandlier and Kench, 2012; Mandlier, 2013). Furthermore, the amount of wave energy that propagates and refracts on the reef flat depends on water level (Lugo-Fernández et al., 1998a, 1994) and therefore, fluctuations of wave energy that reach reef islands shorelines are observed at tidal time scale.

Wave energy can also highly differ on a seasonal time scale for a specific location. Reef islands have shown to be highly sensitive to such fluctuations in the intensity and direction of oceanic waves (Dawson and Smithers, 2010; Kench and Brander, 2006a; Kench et al., 2009b). Substantial morphological changes may be observed through large reversals in sediment flux, in response to climate driven (monsoonal) changes on a seasonal basis (Kench and Brander, 2006a). However they may be oscillatory in nature, often resulting in minimal annual net shoreline changes, indicating a spatially balanced pattern of shoreline adjustment (Kench and Brander, 2006a). Low frequency events, such as tropical cyclones, may imply in rapid wave energy and water level increase on an atoll and may initiate the formation of a reef island or trigger a 
significant change in an existing island. The immediate event may have a duration of only a few hours but it may initiate a change that may last several years until a new stable situation develops (Gourlay, 1988). As consequence, morphological differences have been identified between atolls in storm-prone areas, and those closer to the equator where tropical cyclones (typhoons, hurricanes) are rare (Woodroffe and Biribo, 2011). In areas that experience occasional storms, rubble may occur along the most exposed beaches whereas in areas without influence of storms, islands are predominantly sandy (Woodroffe, 2008). This highlights the mobile nature of reef island beaches and their adjustments in response to changing boundary conditions.

Although many studies focused on planform variations of reef islands (Ford, 2013; Houser et al., 2014; Kench and Brander, 2006a; Kench et al., 2014, 2009b, 2006; Rankey, 2011; Webb and Kench, 2010; Yates et al., 2013), vertical adjustments (erosion or accretion) can play a significant role on the overall mobility of islands (Beetham and Kench, 2014; Dawson and Smithers, 2010; Smithers and Hoeke, 2014) and may not necessarily imply in significant horizontal changes. This requires a three dimensional methodological approach of morphological changes where differences in elevation and volume can be measured and compared for different periods. Through a combination of historical data and in situ synchronous measurements of volumetric changes and wave energy, this study examines the morphological behavior of reef islands on Rocas Atoll at three time scales (daily, seasonal and decadal). The Rocas Atoll is a small-sized shallow lagoon atoll build by coralline algal (Gherardi and Bosence, 2001; Kikuchi and Leão, 1997), being the only atoll in the South Atlantic Ocean. Located slightly south of the equator (-3.8 degrees of latitude), Rocas is outside the tropical storm belt and is dominated by southeast tradewinds, receiving persistent swell on all sides of the atoll (Chapter 2).

Our findings allow the discussion about the mobility of the entire reef islands (beach and central parts) in response to seasonal wave regime on a three dimensional perspective and the adjustment of sediments between the islands over the last decades. Moreover, Rocas Atoll has some topographic and climatic peculiarities which can contribute to establish the continuum of variations in atoll morphodynamics patterns.

\subsection{Methods}

Two expeditions of approximately 35 days each were conducted to Rocas Atoll to collect synchronous wave and topographic data. The period of each expedition was planned to cover two different seasonal wave conditions on Rocas Atoll. The first expedition (E1) was conducted in November 2012, corresponding to the period where the atoll is subject to northern swell incidence, controlled by the northern hemisphere extratropical cyclones (Chapter 2). The second expedition (E2) in July 2013 covered 
southern swell dominance at the atoll, controlled by southern hemisphere extratropical cyclones (Chapter 2).

\subsubsection{In situ wave data}

Wave data has been obtained through the mooring of Aquadopp acoustic Doppler current profilers (ADCP) ( $2 \mathrm{MHz}$ and $1 \mathrm{MHz}$ frequency) throughout both data collection periods. In the first expedition (November 2012), one ADCP was placed northwest of the atoll, at a depth of $15 \mathrm{~m}$ and approximately $700 \mathrm{~m}$ from the leeward edge of the atoll to measure the predominant northern swells. In the second expedition (July 2013) when incident waves are dominated by southern swells, one ADCP was placed southeast of the atoll, at a depth of $16 \mathrm{~m}$ and approximately $300 \mathrm{~m}$ from the windward edge of the atoll. The ADCPs operated intermittently with a sampling frequency of 2 $\mathrm{Hz}$. The wave characteristics were measured in bursts of 2048 samples (17.1 $\mathrm{min}$ ) per hour. A summary of the deployment conditions is shown in Table 4.1.

Table 4.1. Instruments deployment information. The instruments' position is shown in Figure 4.1.

\begin{tabular}{cccccccc}
\hline Expedition & Location & Depth & Instrument & Deployment & Duration & $\begin{array}{c}\text { Sampling } \\
\text { frequency }\end{array}$ & No. bursts \\
\hline E1 & $\begin{array}{c}\text { Northwest } \\
(N W)\end{array}$ & $15 \mathrm{~m}$ & ADCP 1MHz & $\begin{array}{c}29 \text { Oct }-23 \\
\text { Nov }(2012)\end{array}$ & 25 days & $\begin{array}{c}2 \text { Hzfor } 17.1 \mathrm{~min} \\
\text { every hour }\end{array}$ & 598 \\
E2 & $\begin{array}{c}\text { Southeast } \\
(\mathrm{SE})\end{array}$ & $16 \mathrm{~m}$ & ADCP $1 \mathrm{MHz}$ & $\begin{array}{c}29 \mathrm{Jun}-27 \\
\text { Jul (2013) }\end{array}$ & 28 days & $\begin{array}{c}2 \text { Hz for } 17.1 \mathrm{~min} \\
\text { every hour }\end{array}$ & 667 \\
\hline
\end{tabular}

\subsubsection{Morphological surveys}

The topography of the reef islands and the shingle bank were surveyed consecutives times over two expeditions (approximately 35 days each) to Rocas atoll to assess their morphological changes on a daily and seasonal scale. Table 4.2 shows the dates of each survey. Surveys conducted within each expedition were used to verify the daily morphological changes, whilst comparison between both expeditions is used to verify the seasonal morphological changes.

Table 4.2. Date of each topographic survey conducted on reef islands and shingle bank of Rocas Atoll.

\begin{tabular}{|c|c|c|c|c|c|c|}
\hline \multirow{2}{*}{ Location } & \multicolumn{3}{|c|}{ First Expediton (E1) } & \multicolumn{3}{|c|}{ Second Expediton (E2) } \\
\hline & Survey 1 & Survey 2 & Survey 3 & Survey 4 & Survey 5 & Survey 6 \\
\hline Farol Island & $01 / 11 / 2012$ & $17 / 11 / 2012$ & $29 / 11 / 2012$ & $06 / 07 / 2013$ & $14 / 07 / 2013$ & $20 / 07 / 2013$ \\
\hline $\begin{array}{l}\text { Cemitério } \\
\text { Island }\end{array}$ & $02 / 11 / 2012$ & $18 / 11 / 2012$ & $30 / 11 / 2012$ & 08/07/2013 & $17 / 07 / 2013$ & $21 / 07 / 2013$ \\
\hline $\begin{array}{l}\text { Zulu shingle } \\
\text { bank* }\end{array}$ & - & 12/11/2012 & - & 07/07/2013 & - & $22 / 07 / 2013$ \\
\hline
\end{tabular}


Topographic surveys were conducted using a dual-frequency kinematic Global Position System (GPS). The equipment consisted of two GPS receivers, one serving as a base station (Trimble 5700) that remained at a fixed position throughout the surveys, and the other as a rover unit (Trimble R4) taken to individual measurement points. A geodetic benchmark (survey mark) on Farol Island was used as the reference point for the base station. Surveys were conducted by an operator walking along parallel transects cross the islands during low tides using the rover GPS unit mounted in a backpack kit (Figure 4.1). Transects extended to the toe of the beach (TOB) which is defined as the intersection of beach sediments with the reef surface and is usually characterized by a distinct break in slope (Kench and Brander, 2006a). The GPS surveys were carried out as post-processed kinematic surveys (PPK GPS), where positional data from the roving GPS was processed with the use of data from the stationary base GPS with the TBC software (horizontal and vertical accuracy of $\pm 20 \mathrm{~mm}$ ). Data were tidally corrected and referenced vertically to the Rocas Atoll Mean Low Water Spring (MLWS) according to the Brazilian Navy. Digital Elevation Models (DEMs) were constructed with the surveyed data using the Kriging method. These DEMs have been used for assessing and quantifying the morphological evolution of the reef islands and shingle bank between surveys. Quantities such as reef islands perimeter, area and volume were obtained from the DEM based on the TOB and the vegetation line (VL) boundaries. 

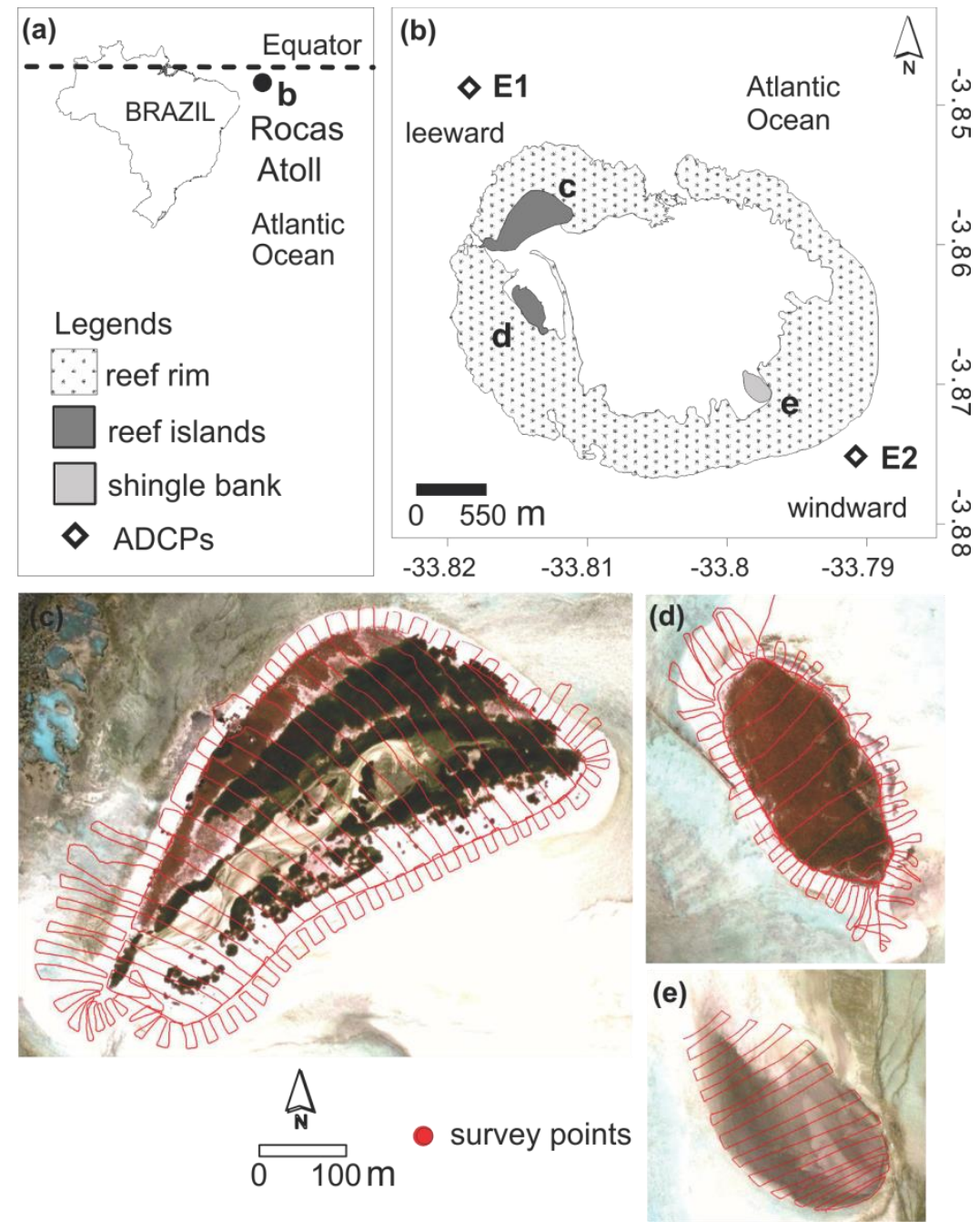

Figure 4.1. (a) Location of Rocas Atoll. (b) ADCPs positions at first (E1) and second expedition (E2). Example of topographic survey points for the (c) Farol Island, (d) Cemitério Island and (e) Zulu shingle bank during expedition 1. Satellite images from Google Earth.

\subsubsection{Historical data}

Decadal changes in the reef islands morphology were based on comparative analysis of geological maps, historical aerial photography and satellite imagery spanning more than 150 years. Most of the material was gathered with the Brazilian Navy, including geologic surveys of islands in the atoll undertaken in 1881 during the construction of the first lighthouse. Older reports from sailors containing descriptions and maps of the atoll, dating back to 1856, were also analyzed. Although with limitations and qualitative, this is the only information available for the area, being very relevant and helpful in defining the systems morphological evolution. 


\subsection{Results}

\subsubsection{Incident wave spectra}

The characteristics and spectra of incident waves in Rocas Atoll during the two different surveyed conditions (fall/winter in the Northern and Southern Hemispheres) are shown in Figure 4.2. The expedition conducted in November 2012 covered the dominant incoming northerly swell, influenced by stormy conditions in the Northern Hemisphere. During the sampling period (approximately 1 month), three northerly swell events (0.05 and $0.09 \mathrm{~Hz}$ frequencies) with a peak period of approximately $13 \mathrm{~s}$ and an associated significant height of $1.5 \mathrm{~m}$, have been observed. Each of these swell events showed a peak of energy during the first days with a gradual energy decrease along time (Figure 4.2). Infragravity wave $(<0.05 \mathrm{~Hz}$ ) energy was identified however spectral densities associated with these long period waves remained low. Greater wave directional spreading and shorter significant height also occurred during periods when the average wave period remained approximately $5 \mathrm{~s}$.

The July 2013 expedition covered the southerly quadrant waves (Figure 4.3), defined by Southern Hemisphere winter conditions. The directional spectrum shows two groups of incident waves (regional wind waves and swell) during the period. Although both are from the southern quadrant, the modal difference in their direction is noted. Incident swell is predominantly from southwesterly direction, while the regional wind waves are predominantly from the southeast. The wave energy density is concentrated in the range of 0.05 to $0.09 \mathrm{~Hz}$ during the beginning of the survey period, representing the incoming swell. Most of the energy was concentrated in the range of regional wind waves (frequencies ranging from 0.1 to $0.2 \mathrm{~Hz}$ ) during the remaining period. The significant wave heights were higher during the incidence of wind waves, with an average height of $1.8 \mathrm{~m}$ and reaching maximum value of $2.5 \mathrm{~m}$. The swell had an associated average height of $1 \mathrm{~m}$.

Wave spectra are characterized by a spread of energy across both swell and windwave frequencies with dominance of swell at the first expedition and wind waves at the second expedition. These measured wave data will serve as boundary condition for the analysis of the morphological evolution of the system throughout the daily to seasonal surveys. 


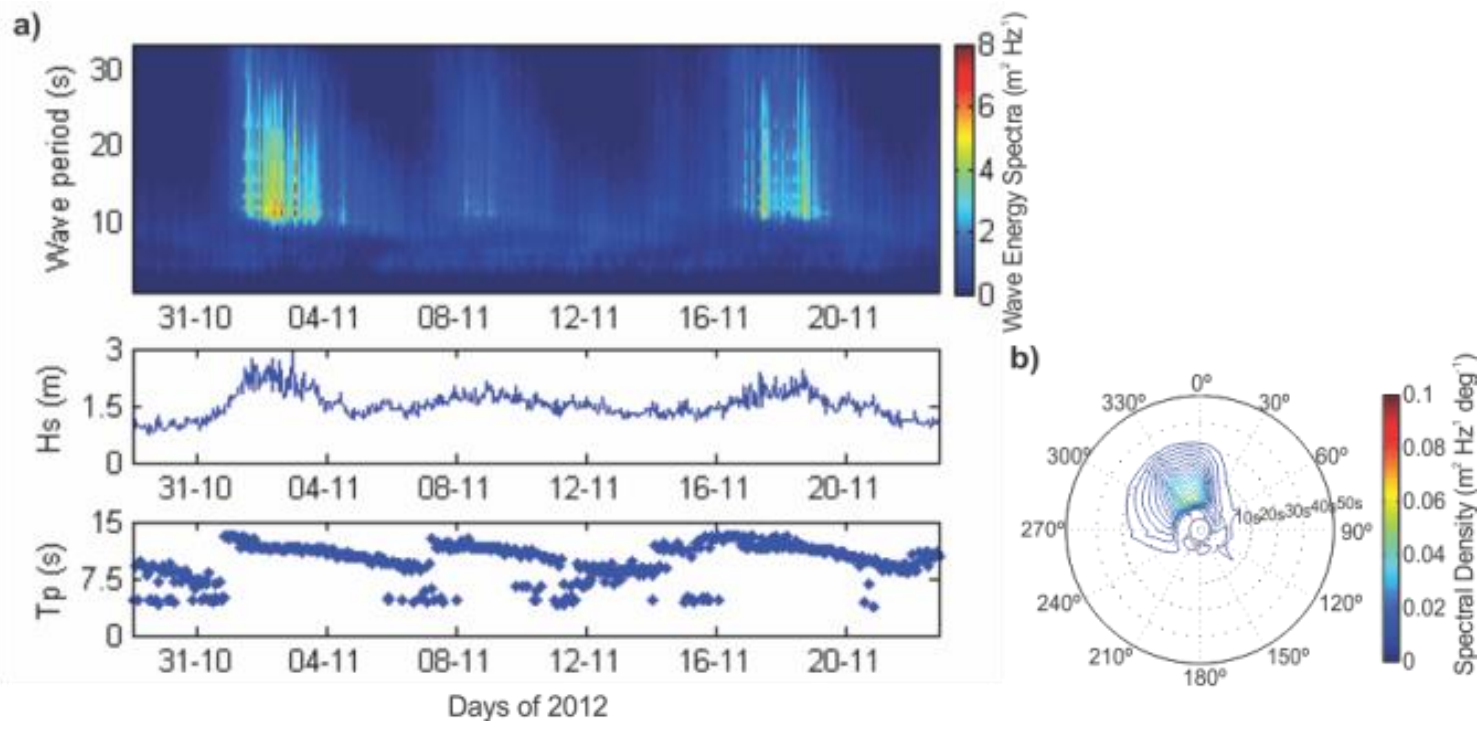

Figure 4.2. (a) Time series of wave spectra and (b) mean directional wave energy distribution during first expedition (November 2012). Means of wave energy distribution were calculate for each frequency at each direction.

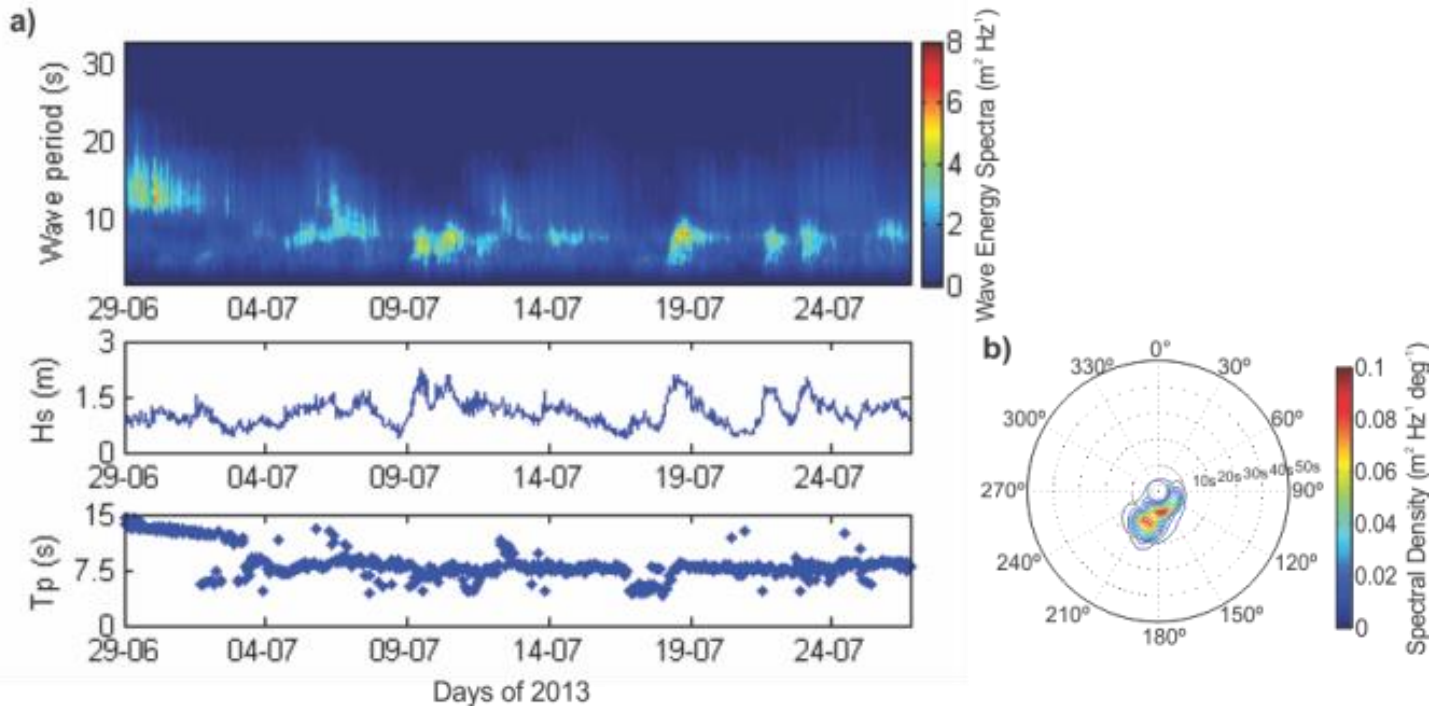

Figure 4.3. (a) Time series of wave spectra and (b) mean directional wave energy distribution during second expedition (July 2013). Means of wave energy distribution were calculate for each frequency at each direction.

\subsubsection{Reef islands and shingle bank morphology}

DEM of Farol and Cemitério Islands and Zulu shingle bank and samples of cross-section profiles are shown in Figure 4.4. Their topographic and planimetric characteristics are shown in Table 4.3. Farol and Cemitério Islands lie on a reef flat the same level (1.5 $\mathrm{m}$ above MLWS). The two islands differ in their planform and profile shapes. Farol is horseshoe-shaped with a series of asymmetric low-elevation ridges and a central depression (known locally as "Baia da Lama" or "Mud Bay" in English). This depression is flooded during high tides, and its pit lies almost at the same level of the surrounding reef flat (1.9 $\mathrm{m}$ above MLWS). The cross-section profile shows that the island is formed 
by three ridges, in addition to the central depression. The oceanward ridge is more prominent, with an elevation of $5.2 \mathrm{~m}$ (which is the highest point on the atoll, disregarding the reef boulders scattered on the windward reef rim). The central ridge is connected to the oceanward ridge and has a maximum elevation of $3.5 \mathrm{~m}$. Its elevation is similar to the lagoonward ridge, which presents a maximum elevation of $3.9 \mathrm{~m}$. However, it has a more irregular topography. When related to the surrounding reef flat elevation the oceanward, central and lagoonward ridges elevations are $3.7 \mathrm{~m}$, $2 \mathrm{~m}, 2.4 \mathrm{~m}$ respectively.

Cemitério Island has an elongated planform shape. The top is flat with only slight asymmetry between the oceanward ( $5 \mathrm{~m}$ above MLWS) and lagoonward ridges ( $4.5 \mathrm{~m}$ above MLWS). The lagoonward side is completely surrounded by exposed consolidated sediments, which are a combination of beachrock, cay stones, and phosphate rock (Figure 4.5). During high tide, waves have a direct impact on these consolidated sediments. The oceanward side has a long beachrock detached from the current coastline in its northern portion and buried in its southern portion. The southeastern portion of the island is the highest part, with $5 \mathrm{~m}$ above MLWS (or $3.5 \mathrm{~m}$ above the surrounding reef flat). In general, the entire top of Cemitério is at the same level as Farol Island's oceanward ridge. Zulu shingle bank has an elongated-shape similar to Cemitério Island. It highest part is also located at the southeastern portion of the bank reaching up to $2.4 \mathrm{~m}$ above MLWS with the steep top facing the windward side.

In terms of surface size, Farol is 2.8 times the size of Cemiterio measured from the toe of the beach and has 3.8 times of its vegetated area. Although the shingle bank it is the lowest in elevation, it has a surface area only 1.6 times smaller than Cemitério. The top of this bank remains exposed during neap high tides and submerged during spring high tides (> $2.5 \mathrm{~m}$ ). Farol and Cemitério have its exposed area reduced to $86,695 \mathrm{~m}^{2}$ (46\% of reduction) and $36,239 \mathrm{~m}^{2}$ ( $37 \%$ of reduction) during spring high tides, respectively. 
(a)
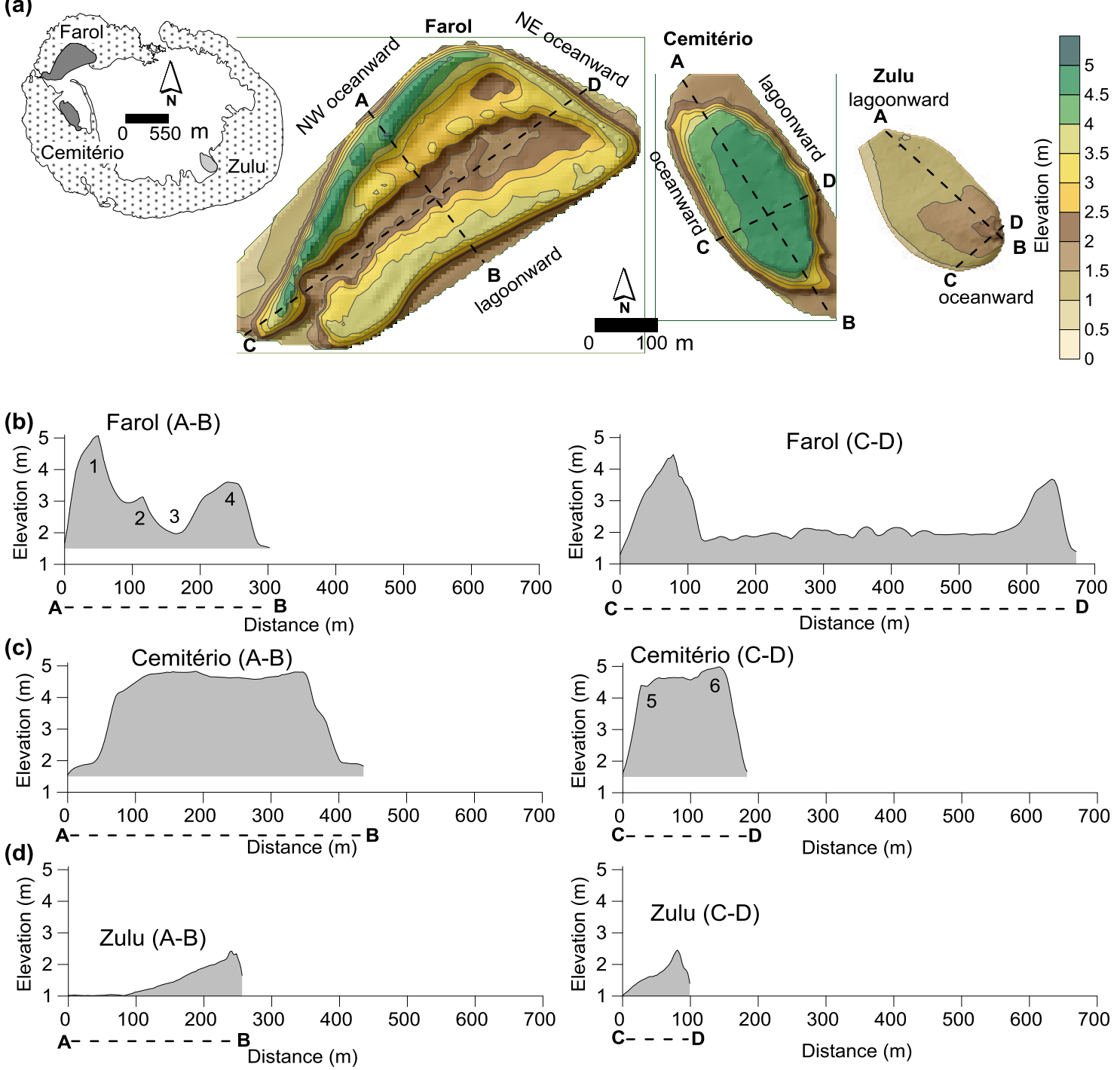

Figure 4.4. Digital Elevation Model (DEM) of Farol and Cemitério islets and Zulu shingle bank with examples profiles from the northwest (A) to the southeast (B) and from the southwest (C) to the northeast (D). The numbering $1,2,3$ and 4 on profile $b$ correspond to NW oceanward ridge, central ridge, central depression and lagoonward ridge, respectively of Farol Island. Conversely, the numbering 5 and 6 on profile c correspond to oceanward ridge and the lagoonward ridge of Cemitério Island. 
Table 4.3. Summary of the topographic characteristics of the reef islands on Rocas Atoll. Estimation of perimeter, area and volume were horizontally limited by the toe of the beach (TOB) and the vegetation line (VL). Volumes estimations were vertically limited by the height of the surrounding reef flat.

\begin{tabular}{cccc}
\hline Topographic characteristics & Farol islet & Cemitério islet & Zulu shingle bank \\
\hline Perimeter $(\mathrm{m})$ & 1730 & 976 & 717 \\
Area $\left(\mathrm{m}^{2}\right)$ & 161725 & 57754 & 34841 \\
Volume $\left(\mathrm{m}^{3}\right)$ & 186436 & 109066 & 11466 \\
Vegetated perimeter $(\mathrm{m})$ & 1547 & 707 & 0 \\
$\quad$ Vegetated area $\left(\mathrm{m}^{2}\right)$ & 120301 & 31603 & 0 \\
$\begin{array}{c}\text { Maximum elevation above } \\
\text { MLSW }(\mathrm{m})\end{array}$ & 5.2 & 5 & 2.4 \\
$\begin{array}{c}\text { Maximum elevation above } \\
\text { reef flat }(\mathrm{m})\end{array}$ & 3.7 & 3.5 & 1.5 \\
Distance from reef rim $(\mathrm{m})$ & 245 & 550 & 505 \\
$\quad$ Position on the reef rim & leeward & leeward & windward \\
\hline
\end{tabular}
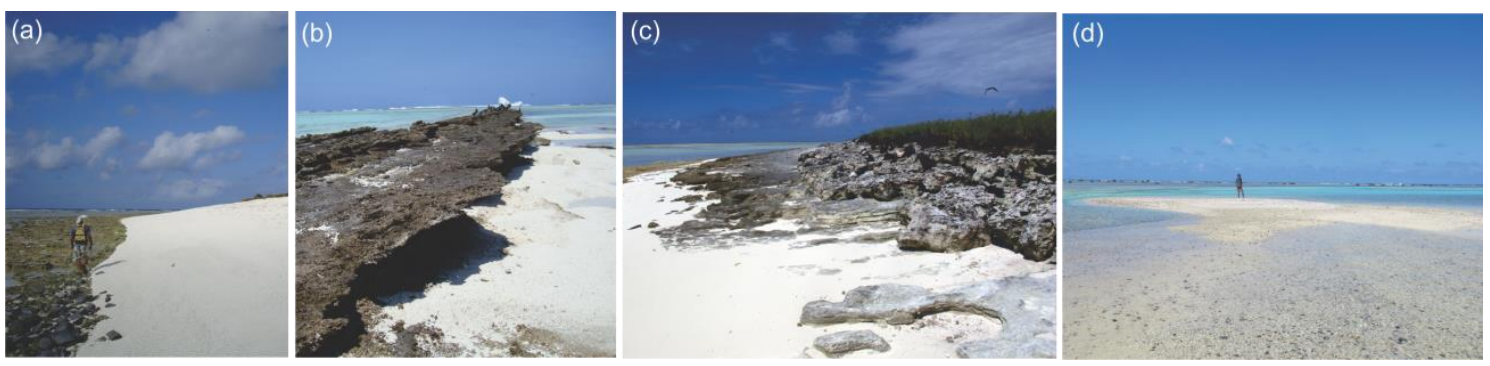

Figure 4.5. (a) Intersection of beach sediments with the reef surface (toe of the beach) of Farol Island. (b) Beachrock on the oceanward beach of Cemitério Island. (c) Consolidated sediments on the lagooward beach of Cemitério Island. (d) Top of Zulu shingle bank during high neap tide.

\subsubsection{Morphological changes}

The DEMs of each topographic survey are show in Figure 4.6, Figure 4.7 and Figure 4.8. The morphological changes on a daily and seasonal scale have been quantified through elevation-change maps extracted by comparison of pairs of DEMs and the results are described below. 

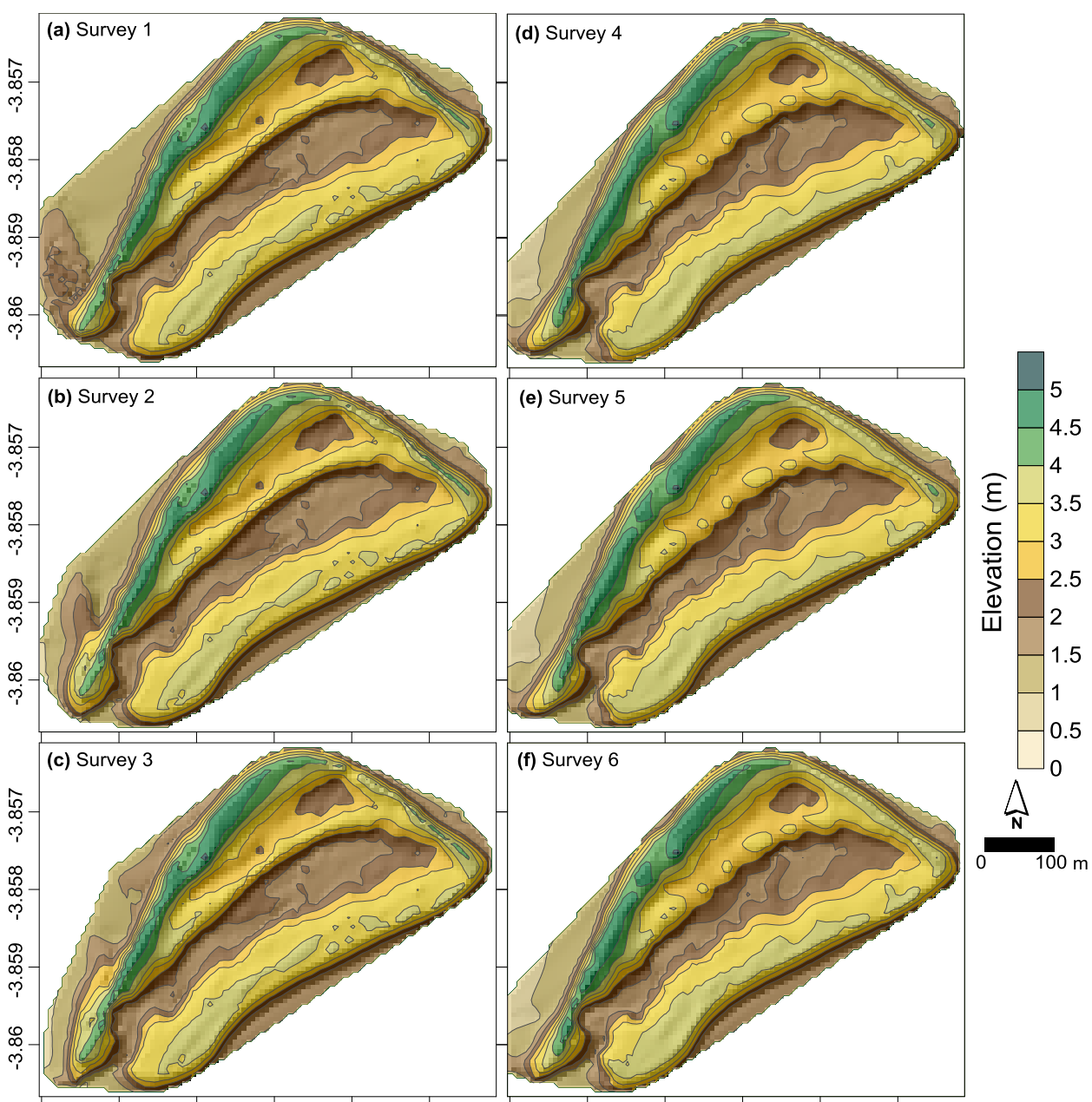

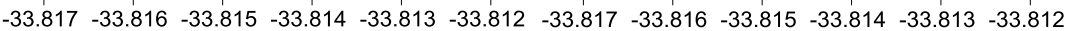

Figure 4.6. Digital elevation model (DEM) of Farol Island generated from surveys conducted during first expedition (a) $01 / 11 / 2012$ (b) $17 / 11 / 2012$ (c) $29 / 11 / 2012$ and the second expedition (d) 06/07/2013 (e) 14/07/2013 (f) 20/07/2013. 


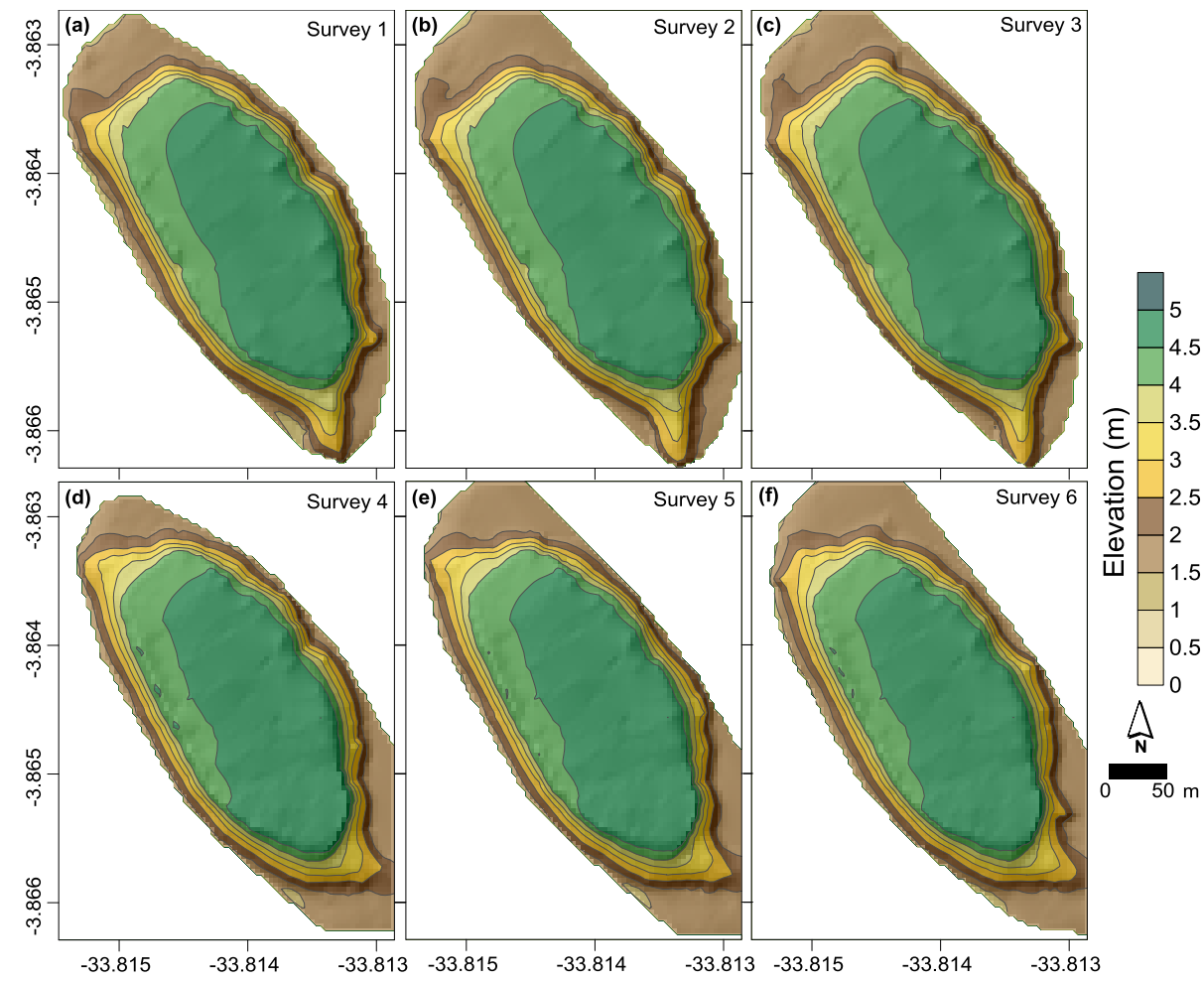

Figure 4.7. Digital elevation model (DEM) of Cemitério Island generated from surveys conducted during first expedition (a) $02 / 11 / 2012$ (b) $18 / 11 / 2012$ (c) $30 / 11 / 2012$ and the second expedition (d) 08/07/2013 (e) 15/07/2013 (f) 21/07/2013.
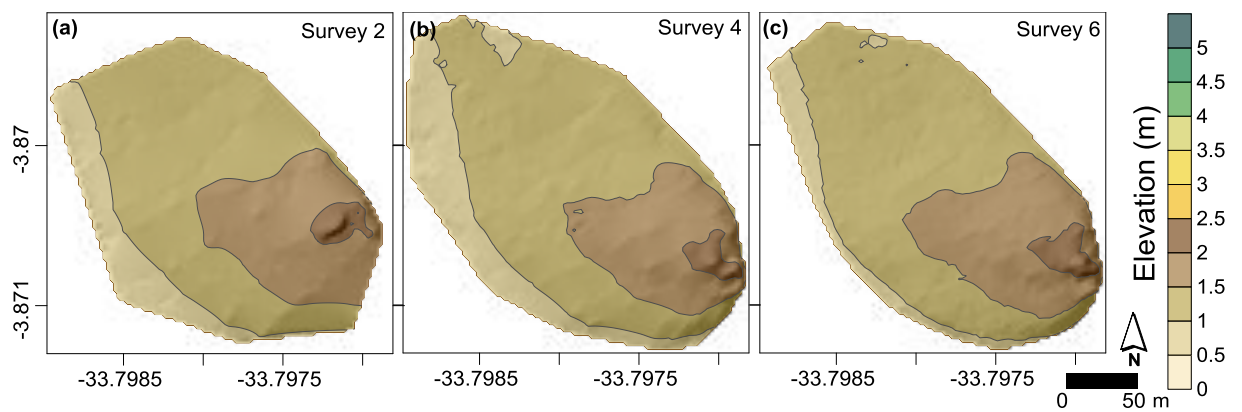

Figure 4.8. Digital elevation model (DEM) of Zulu shingle bank generated from surveys conducted during first expedition (a) 12/11/2012 and the second expedition (b) 07/07/2013 (c) $22 / 07 / 2013$.

\section{Daily morphological changes}

Topographic surveys conducted along the November 2012 expedition at few days intervals indicate significant changes in the NW oceanward beach of the Farol Island in response to the northern swell. This area has a volume increase during the surveyed period (Figure 4.9a). Maximum elevation gain was of $2.1 \mathrm{~m}$ at this beach compartment. Simultaneously, sediments from the reef rim were remobilized and deposited on the beach side. The DEMs (Figure 4.6a,b,c) and difference elevation maps (Figure 4.9a) clearly show that the sandbar at the southern end of the island is shifted and attached to the beach. The rest of the oceanward beaches, including the NE oceanward sector, present less changes with only small erosion. The lagoonward beach remained stable. The net volume accretion was of $1856 \mathrm{~m}^{3}$ (approx. 1\% of the total island volume), the 
highest recorded at this time scale and it was mainly concentrated in the south of the NW oceanward beach. In July 2013, during southern wave incidence, the lagoon side was also stable and small volumetric changes were again concentrated on the southern end of the NE oceanward beach (Figure 4.9b). During this period however, erosion dominated and the total volumetric loss was of $-779 \mathrm{~m}^{3}$ (approx. $0.4 \%$ of total island volume).

Short term surveys show that at Cemitério Islands remains stable during both period (November 2012 and July 2013) (Figure 4.9c,d). Maximum elevation differences were $0.80 \mathrm{~m}$ (both for elevation loss and gain) and were mainly observed in the northern and southern ends of the islands. During the northern swell period (November 2012), accretion can be observed at the northern side of the island, with volume gains concentrated in the northeast and small losses in the northwest portion. The total gross volume change represented about $0.8 \%$ of the total island volume. Southerly waves in July 2013 resulted in smaller changes than in November 2012. Erosion in the northwest portion of the north side of the island represented $0.3 \%$ of total island volume. Net volumetric changes for both periods are similar (approx. $0.2 \%$ of the island volume), but positive (accretion) during northern swell and negative (erosion) for southerly waves.

Logistics only allowed surveys of the Zulu bank for southern wave conditions (July 2013), during which it remained virtually stable (Figure 4.9e). Maximum observed elevation difference was of $0.55 \mathrm{~m}$ with net volumetric changes of $24 \mathrm{~m}^{3}$, representing about $0.2 \%$ of the total bank volume.

During the short term surveys, net volume change on the islands and shingle bank was up to $1 \%$, with higher variability during northern swell incidence (November 2012). In terms of gross volume, Farol Island presents largest variations with a total of $5.4 \%$ during northern swell incidence and $0.6 \%$ during southern wave conditions. Comparatively, total gross volume change on Cemitério was always below $0.8 \%$ of the total island volume. 


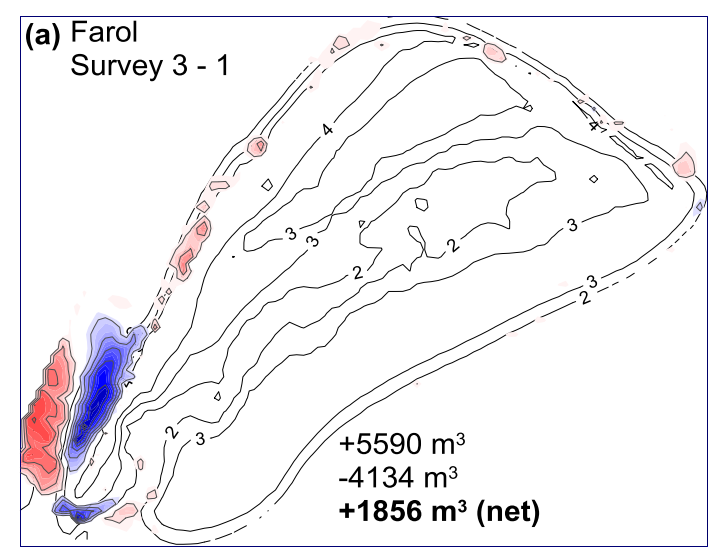

(b) Farol
Survey $6-4$

(c) Cemitério Survey 3-1

(d) Cemitério Survey 6 - 4

(e) Zulu Survey 6 - 4
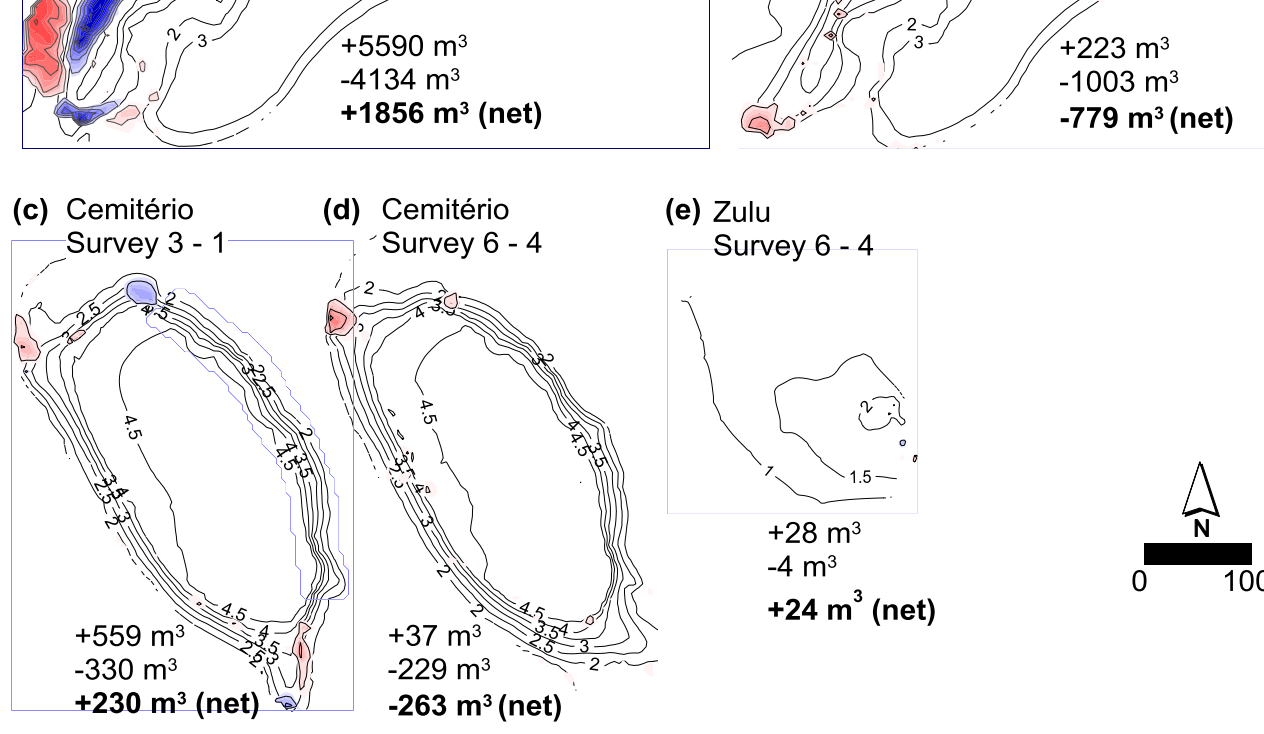

$+24 \mathrm{~m}^{3}$ (net)

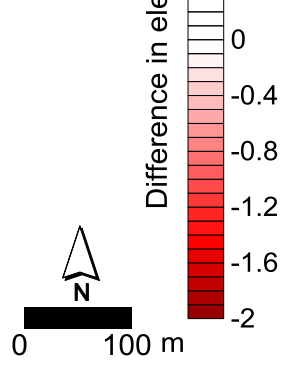

Figure 4.9. Difference in elevation between the last and the first survey on each expedition. Red colors represent loss of sediment whereas blue color represents gaining. Gross volume accretion and gross volume erosion are indicating by positive number and negatives numbers, respectively. Net volume change is indicating by bolds numbers. The date of each survey is showed on Table 4.1. They correspond to an interval of approximately 30 days.

\section{Seasonal morphological changes}

The seasonal comparison of the Farol Island morphology between November 2012 and July 2013 showed the largest gross volumetric changes of sediment (Figure 4.10a). Gross erosion was $-10024 \mathrm{~m}^{3}$ (5.4 \% of total island volume) and mainly concentrated on the oceanward beaches and at the central depression. However gross accretion was also high ( $9974 \mathrm{~m}^{3}$ or $5.3 \%$ of total island volume) indicating that erosion was compensated by accretion at adjacent areas. Thereby, the net volume change was insignificant $\left(-50 \mathrm{~m}^{3}\right.$ or $0.1 \%$ of total island volume). Specifically, the higher gross volumetric changes were observed on the NW oceanward beach. Sediment accumulation observed under northern swell incidence (November 2013) was eroded and the adjacent area to north was accreted. As result, this side returned to the morphological stage similar to that preceding the incoming northern swell. On the NE oceanward beach and at the central depression erosion was predominant, but despite the great mobility on those compartments, the overall net volumetric change was very small. Erosion on the central depression was characterized by reduction of elevation 
on the central ridge. Conversely, the lagoonward beach showed little change, with erosion located at its northern end and accumulation at the southern end.

The opposing ends of the Cemitério Island exhibited most gross volumetric variability (Figure 4.10b). The spit on the southern end was shifted 45 degrees to east. Similarly, the north end showed erosion and accretion on adjacent areas. The oceanward beach was also partially eroded. However, the lagoonward beach, protected by consolidated sediments, remained stable. The central vegetated part of the island also remained stable. The total erosion represented $2.6 \%$ of total island volume $\left(-2795 \mathrm{~m}^{3}\right)$ and the total accretion represented $2.1 \%$ of total island volume $\left(2319 \mathrm{~m}^{3}\right)$. Net volumetric change was only about $0.4 \%$ of the total island volume $\left(-477 \mathrm{~m}^{3}\right)$

Morphological changes on Zulu bank were concentrated on its highest portion. Between the surveyed seasons (November 2012 to July 2013) the bank top was displaced $35 \mathrm{~m}$ to southeast (Figure 4.10c). However, its maximum height remained constant. The net volumetric change was only $-30 \mathrm{~m}^{3}$ ( $0.3 \%$ of the total bank volume).
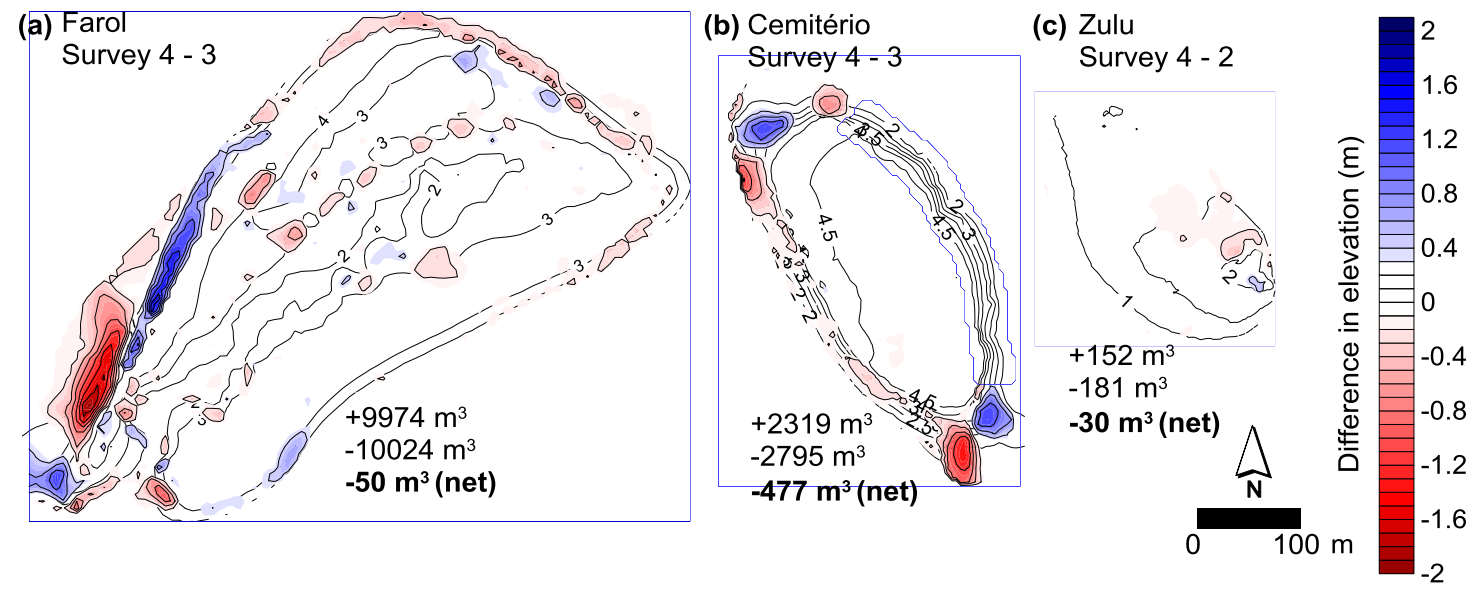

Figure 4.10. Difference in elevation of (a) Farol and (b) Cemitério reef islands and (c) Zulu shingle bank between two expeditions. Red colors represent loss of sediment whereas blue color represents gaining. Gross volume accretion and gross volume erosion are indicating by positive number and negatives numbers, respectively. Net volume change is indicating by bolds numbers. The date of each survey is showed on Table 4.1. They correspond to an interval of approximately 6 months (between two seasons).

\section{Decadal morphological changes}

The reports and historical maps containing descriptions of Rocas Atoll completed between 1856 and 1940 refer to the Farol and Cemitério Islands as being approximately the same size (Conceição Junior, 1881; Costa Junior, 1902; Findlay, 1867; Oliveira, 1858; Parisch, 1856). The islands sizes reported at that time are similar to the current vegetated land area of Cemitério $\left(31,603 \mathrm{~m}^{2}\right)$, with an area of $34,637 \mathrm{~m}^{2}$ for Farol and $31,513 \mathrm{~m}^{2}$ for Cemitério (Rodrigues, 1940). Farol Island was reported as longer and thinner than Cemitério (Oliveira, 1858). Currently, Farol Island shows a 
width that is approximately double the width of Cemitério (Figure 4.4). In terms of vegetated area, the Farol Island increased by 59.6\% $\left(85,664 \mathrm{~m}^{2}\right)$ between 1939 and 2013.

Historic data indicate that Cemitério Island experienced only few changes to its morphology, which is highlighted by the description of its ellipsoidal shape and area similar to current situation, whereas Farol Island experienced significant changes during this period. Farol Island was described as being hook-shaped, with its center as the highest part. Surveys conducted by Mello and Alvim in 1881 (reported in Petit 1922) during the construction of the first lighthouse in Rocas Atoll indicate that the island profile was very different from its current form, with only the oceanward ridge existing. No mention of the central depression is found in documents prior to 1940. The 1881 survey reports that a provisional lighthouse was erected on the highest and central part of the island (Petit, 1922), which currently corresponds to the oceanward ridge. Subsequently, a lighthouse keeper house and a cistern were also built in the same area (Costa Junior, 1902).

In 1939 , the provisional lighthouse was replaced by a brick lighthouse (Rodrigues, 1940). In that year, the lighthouse keeper house was already in ruins, albeit still amidst the vegetated part of the island (Figure 4.12c,g). The photographs taken in 1939, during the inauguration of this lighthouse (Rodrigues, 1940), show the hook shape of Farol Island (Figure 4.11a, b). A photograph taken from the same angle, in 2014, shows the difference in the terrain, with a considerable accretion towards the lagoon (Figure $4.11 c, d)$. The comparison between both figures shows the evolution of the ridges and the central depression. The photographs also indicate the presence of a spit on the southern portion of the island, just off Barretinha reef passage, whose shape is currently preserved (Figure $4.11 \mathrm{~b}, \mathrm{~d}$ ).

The erosion of the oceanward side of Farol Island is another aspect that noticeably stands out when comparing older photographs. The above mentioned brick lighthouse, built in 1939 in the central part of the island and amidst the vegetation, currently lies on the toe of the beach (Figure 4.12d, h, i). Its foundation, built in concrete and fixed 3 $\mathrm{m}$ below the sand surface (Rodrigues, 1940), is currently found completely exposed on the beach side (Figure 4.12i). Another evidence are the concrete stones that were laid on the top of the island to serve as building material for the lighthouse and lighthouse keeper's house in 1881 (Rodrigues, 1940; Vinhaes, 1929); currently, they are on the reef flat (Figure $4.12 \mathrm{~g}, \mathrm{~h}$ ). 
(a)

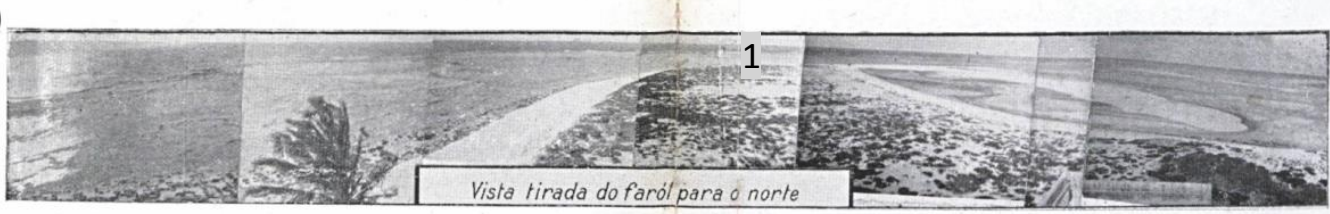

(b)

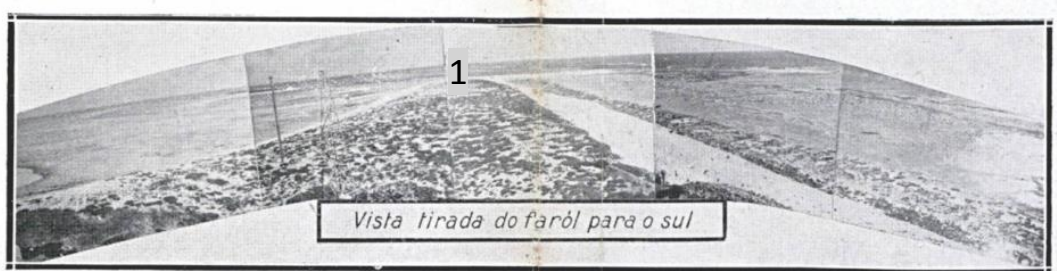

(c)

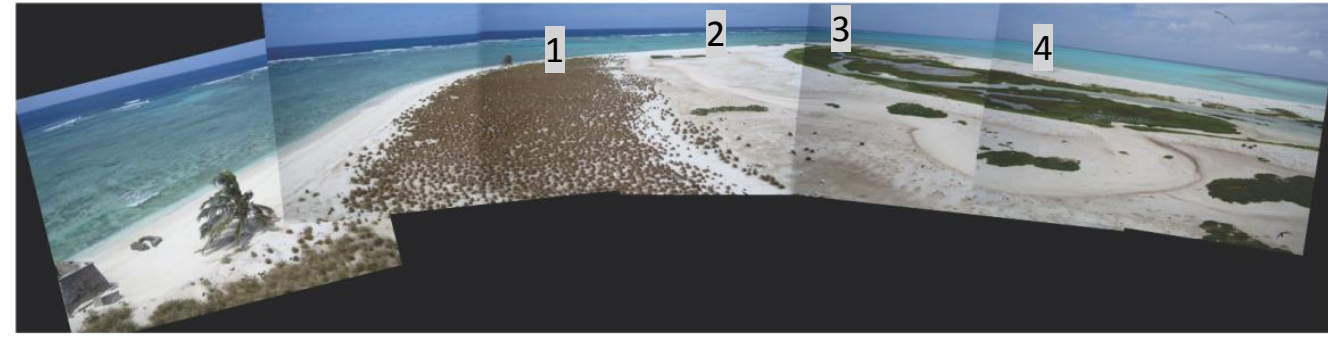

(d)

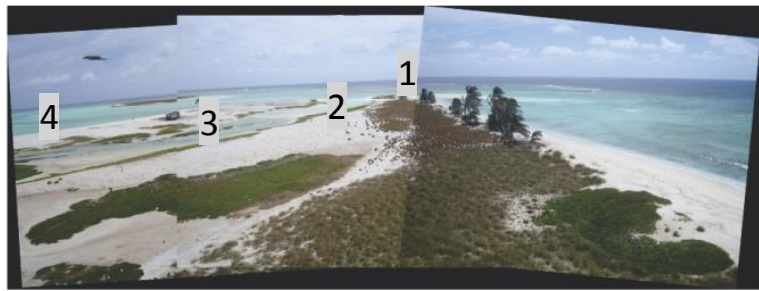

Figure 4.11. Photographs of Farol Island from (a,b) 1939 and (c,d) 2014. The numberings 1, 2, 3 , and 4 correspond to the oceanward ridge, central ridge, central depression, and lagoonward ridge, respectively. 


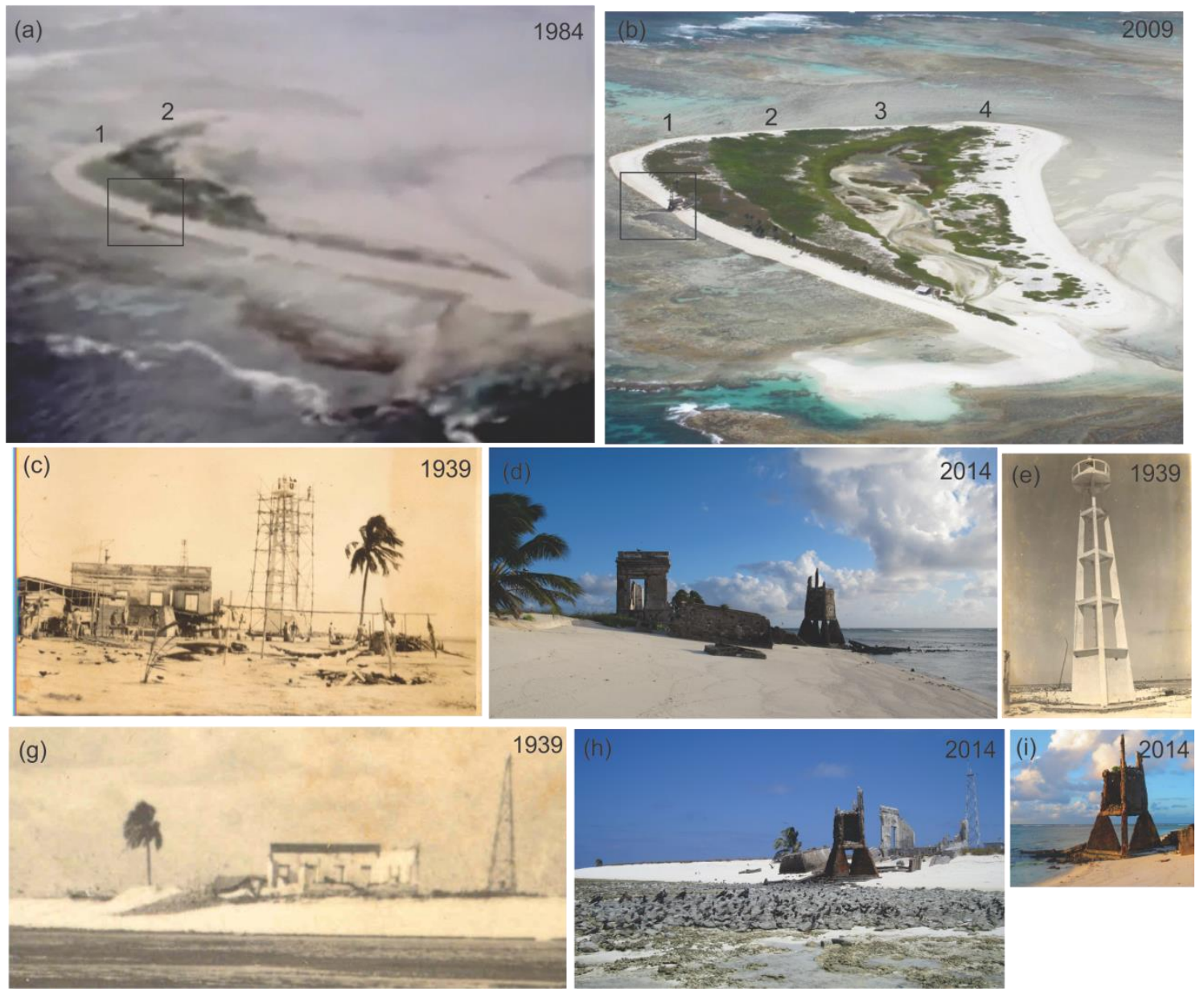

Figure 4.12. Photographs of Farol Island at different times (from 1939 to 2014), showing the growth of the island towards the lagoon and the erosion of the oceanward beach. The year of each photograph is displayed on the upper right corner. The numberings $1,2,3$, and 4 correspond to the oceanward ridge, central ridge, central depression, and lagoonward ridge, respectively.

The 1984 aerial photograph (Figure 4.12a) also shows that the central ridge was already partly formed, which is not observed in the 1940 photograph (Figure 4.11a). The comparison between both photographs (Figure 4.12a, b) shows that central ridge accretion, central depression formation and accretion of the third and most recent ridge occurred between 1984 and 2009 (25 years). It is also noted that most of the masonry lighthouse was still within the vegetated area in 1984 (Figure 4.12a), whereas in 2009 it is completely on the beach face (Figure 4.12b).

It is noteworthy that the first maps and descriptions performed by the English and French, preceding the construction of the lighthouse, refer to Farol Island as Sand Island (or Sable in French) and to Cemitério Island as Grass Island (Lee, 1854). Nowdays, Farol Island shows a denser and more diverse vegetation, consisting of grasses (Portulaca oleracea, Cyperus ligularis, Iresine portulacoides) and some coconut trees (Cocus nucifera), while Cemitério Island is densely vegetated by Cyperus ligularis only (Hazin and Macedo, 2006). Oliveira (1858) also describes the surface sediments of 
Farol Island as covered by a $40-\mathrm{cm}$-thick layer of phosphate, with the presence of thin vegetation comprising wild purslane and Cemitério Island with the presence of clumps of grass and some palm trees. The sparse vegetation on Farol Island, compared to Cemitério Island in 1958, may be interpreted as indicative of a more recent stabilization of its surface.

Lastly, the presence of a series of semi-submerged banks, described by Oliveira (1858), in the vicinity of Farol Island is highlighted. Oliveira describes Rocas Atoll in three elevation levels: the first and highest, which consists of Farol and Cemitério Islands, which remain emerged even in the spring high tides; the second, which consists of a series of sand banks located immediately next to Farol Island and exposed at a height of $1 / 3$ ebb tide, and lastly, the reef rim with a lower elevation. These high crested sand banks, near Farol Island, are not observed nowadays. Currently, the sand apron, near Farol Island is flat. No mention regarding the presence of the Zulu shingle bank is found in the older reports and maps. The first mention to this sedimentary deposit is found in recent works (Fischer et al., 2007; Pereira et al., 2010).

\subsection{Discussion}

The results show difference in the morphological behavior on a daily, seasonal and decadal scale between both reef islands and the shingle bank of Rocas Atoll. Farol Island is the most dynamic feature over those three temporal scales. In contrast, Cemitério Island was morphological stable for the same period. The results suggest a sediments readjustment between the islands on a decadal scale with substantial accretion at Farol Island. Recent data based on seasonal and daily morphological evolution show only small changes due to wave incidence, which may indicate a slowdown in accretion processes on Farol Island.

\subsubsection{Response to incident wave energy}

Reef islands are inherently sensitive to changes in the intensity and/or the direction of wave energy on a reef platform (Dawson and Smithers, 2010; Gourlay, 1988). Seasonal wind reversals can drive differences in wave energy gradient over the reef flat and result in significant changes in island size, shape and position (Kench and Brander, 2006a; Kench et al., 2009a). In turn, tropical cyclones are recognized as the major environmental driving force on the morphological change of reef islands in stormprone areas (Flood and Jell 1977; Maragos et al. 1973; Bayliss-Smith 1988). Rocas has a relative stable climatic condition in part due to its location near the Equator and outside the tropical cyclone belt (Chapter 2). The wave climate is dominated by southeast trade wind waves almost the entire year and superimposed to seasonal northern swell from October to April and southern swells from May to September (Chapter 2). 
The results show that most volumetric changes in the reef islands occurr in response to energetic swell from north and they were mainly concentrated in the Farol Island. Northern swell impacts directly the leeward margin of the atoll, where the reef islands are placed, thus dissipating less energy on the reef platform before reaching the islands shores. As demonstrated by Kench and Brander (2006a), the quantity of wave dissipation is also related to reef width, which in Rocas is narrower between the leeward rim and the oceanward island shore. This oceanward shore of Farol Island presents largest sediment mobility. Besides this shore is the nearest to the reef edge and is composed by coarse sand size sediments only (Pereira et al., 2013), which makes it especially vulnerable to remobilization by northern swell.

However, instead of gradual erosion in response to northern swell incidence, a large sediment accretion is observed on the oceanward beach at short term scales. This accretion process might be the result of sediments scattered on the leeward reef rim being transported to the island by wave related processes. As observed through the sequence of morphological surveys, a large quantity of sediments from the reef passage was transported back to the beach promoting accretion. During dominant wave conditions, sediments tend to leave the atoll through the outflow in the reef passage (Chapter 3 ). The transport of sediment back to the lagoon is thought to be due to the intense wave set-up generated by northern swell waves breaking on the leeward reef edge which creates a strong flow in the opposite direction of the dominant flow, moving sediments to the island's oceanward beach. Thereby, results show that northern swell can promote accretion on Farol Island since sediment is available for transport on the reef rim. Seasonal topographic comparison showed that the sediment accreted by the northern swell were eroded and the reef island morphology was reestablished to the one similar to pre- north swell morphology. This suggests a cyclical pattern of sediment between the two marked seasons, without significant net sediment loss or gain.

Small morphological changes occurred on both reef islands under southern swell and trade wind wave incidence. The mobility of the island shorelines was, again, concentrated at the oceanward beaches and mainly on their final portion. The lagoonward face, which is turned to the windward rim, remains stable even during this period. Wind-wave energy is filtered out rapidly when propagating across the reef platforms (e.g. Kench et al., 2006) thus reducing the potential for waves to influence the shoreline. Refraction of ocean swell around an atoll, however, can deliver most of swell waves energy to the leeward side of the atoll (Kench et al. 2006). This difference in the way that long and short waves interact with the atoll structure and the gradient in wave energy, could explain why the greatest mobility was observed on the oceanward beaches of the reef island. 
Furthermore, seasonal data suggests that morphological changes on Farol Island are not constrained to processes acting on the shoreline. Significant morphological changes were also observed at the central depression (mud bay) marked by the central ridge breach (Figure 4.4a, b) and consequent extension of its internal intertidal area. In addition, the northern shore of the island has been eroded between the two seasons, reducing the ridge width that encloses the mud bay. If this erosion progresses, breaching of the rim could occur on the northern part of the island. This would result in waves reaching the central portion of the island, which may cause the destabilization of the island. Similar processes, with the breach and flooding of the central island depression were reported to occur at Chagos Islands (Sheppard, 2002). Despite the central depression of reef islands being recognized as low energy areas, progressive erosion could lead in large modifications on the reef island morphology. For instance, the old research station in Farol Island is currently undergoing severe erosion, driven mainly by the intertidal central depression inlet migrations. Major morphological changes on the central depression are likely to be triggered by extremes events, which for Rocas atoll consist in energetic ocean swell occurring simultaneously to high spring tides (Chapter 2). However, a detailed study should be performed to assess the aspects of central depression morphodynamics.

Although Farol Island showed high mobility on its oceanward beach in response to wave incidence and additional modifications in the central depression, the Cemitério Island did not show significant morphological changes. The existence of consolidated sediments on their beaches creates a degree of stability by protecting the island of the direct impact of the waves. Moreover, the center of this island is high and stabilized by dense vegetation. Changes were only observed at the southeast and northwestern ends of the island, on a seasonal basis, by a shift in the orientation of spits toward the lagoon. These two aspects contribute to stabilize the island in its current position by increasing its resistance to wave action.

\subsubsection{Morphological adjustment of reef islands}

Results show that Farol Island had a substantial accretion on a decadal base. Since 1939 net island area has increase by $59.6 \%\left(85,664 \mathrm{~m}^{2}\right)$ lagoonward. This accretion was followed by a pronounced change in its planform morphology, which passes from one elongated ridge morphology to horse-shoe shape with three ridges and an intertidal central depression. Based on these findings a new model for the development of Farol Island can be discussed.

According to the historical data, the oceanward ridge has been formed first, followed by the central ridge and more recently by the lagoonward ridge, which enclosed the intertidal central depression forming an internal shallow lagoon. The accretion of the island appears to have occurred through the curving spit growing towards the lagoon at the northern end of the island (see Figure 4.11). This growth model towards the 
lagoon is similar to the one proposed by Guppy (1889) for the smaller reef islands of Keeling Island. The author described the elongating spits that become stabilized by vegetation, ultimately joining and form what he termed an atollon, a horseshoeshaped islet with a shallow internal lagoon (or lagoonlet). The lagoonlet can be comparable to the intertidal central depression (mud bay) of Farol Island.

For Guppy (1889), the extremities of such islands initiate as sand-banks, which are elongating due to unidirectional currents that transport the sediments lagoonward by inter-island passages. The resulting lagoonlet is thus orientated perpendicular to the reef edge (Figure 4.13). Radiocarbon dating of reef island's sediments performed by Woodfroffe (1999) supports the concept of island extension by spit elongation around and into the lagoon. Although Farol Island shows similar growth pattern, detailed studies should evaluate specific aspects about the sediments source and the accretion frequency. For example, it is not clear if the formation of the ridges and the total accretion at Farol Island were mainly promoted by low frequency extreme events or by gradual unidirectional currents acting on the available sediments.

As shown in Chapter 3, currents on Rocas Atoll are unidirectional from windward to leeward during dominant southeast trade wind waves. The lagoon is filled in part by a large sand apron through which sediments can be transported by these dominant currents culminating in Farol Island position. Moreover, results suggest the sediment accreted on the Farol Islands could be derived from sediment readjustment between the islands during the last decades. This is supported mainly by two evidences. First, as mentioned by (Oliveira, 1858), a series of high crested sand banks were observed between both islands. Nowadays, the two islands are connected by a flat sand sheet exposed during low tides. Secondly, despite Cemitério Island did not show significant changes on a decadal basin, preserving the same land area as observed in 1939, the presence of exposed consolidated sediments on both shores may indicate that the island has suffered erosion at both sides, and probably it was larger than presently. However, these modifications must have occurred beyond the time covered in this study. Thereby, it is possible that the source of sediments accreted in Farol Island has come from the readjustment of Cemitério Island, forming at a first moment the sand banks mentioned by Oliveira (1858), added to sediment transported by the unidirectional currents acting on the sand apron. In addition, it is also shown in this study that seasonal northern swell can add sediment to the oceanward shoreline of Farol Island, which is later reworked to adjacent areas. Those are possible sources of sediments for Farol Island, which must be study in detail. Once sediment is available, it can be reworked in the form of spit elongation process by waves and currents.

It is also important to highlight that the decadal lagoonward accretion of Farol Islands was followed by oceanward erosion. The lighthouse built on the center of the elongated island in 1935, is now at the toe of the beach at the oceanward side of the 
present horse-shaped island. Although we have been assessing the morphological evolution at a decadal scale rather than a millennial scale, this type of accretion appears to conform to the 'rollover' model proposed by Woodroffe et al. (1999). This pattern of reef islands migration toward the lagoon has been observed in several islands on the Indo-Pacific, and has been related to being a consequence of sea level rise (Webb and Kench, 2010). An increase in sea level increases the water depths across the reef surface, allowing larger waves to impact oceanward beaches of the reef islands (Sheppard et al., 2005). However, instead of generalized erosion, several studies have shown that the islands tend to move away from the reef edge even with some accretion in area such as observed for the Farol Island. In fact, it has been suggested that changes in sea level can change the not only the wave energy, but also the refraction patterns and consequently the zones prone to sediment accumulation on a reef platform (Chapter 5; Mandlier and Kench, 2012). These findings reinforce the resilient nature of reef islands and show that even on a climate change scenario, sediments on atolls and reef platforms can suffer rearrangements that not necessarily imply in net island erosion.
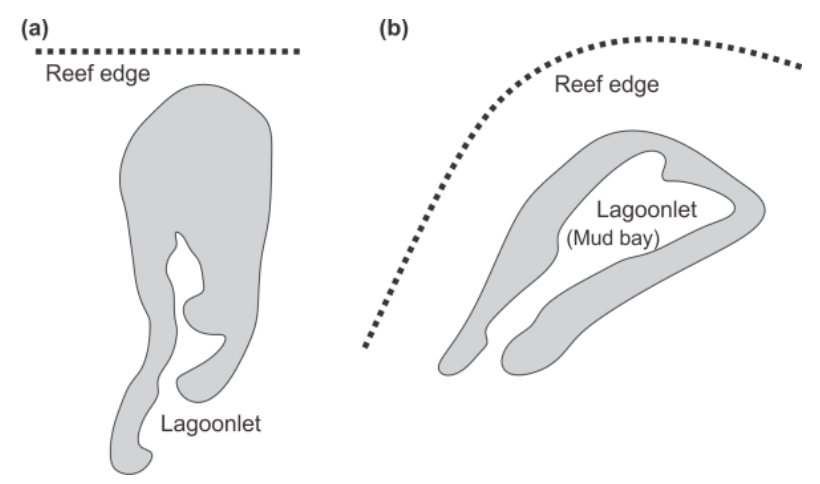

Figure 4.13. Comparisons between a (a) small reef island on Keeling Island (Pulu Kembang) and (b) Farol Island on Rocas Atoll. Note the difference in orientation of the shallow internal lagoon (termed lagoonlet by Guppy 1889) in respect to the reef edge. The figures are not scaled. 


\section{Chapter 5}

\section{RESPONSE OF WAVE REFRACTION TO SEA LEVEL RISE ON ROCAS ATOLL: IMPLICATIONS FOR REEF ISLANDS MORPHODYNAMICS}

\subsection{Introduction}

Wave refraction provides a major driving mechanism for reef top hydrodynamics which subsequently control the entrainment and transfer of sediment to depositional centers on the reef flat (Gourlay, 1988; Mandlier and Kench, 2012). Open ocean swell is filtered at the reef crest, but a component of the wave energy crosses the reef flat and reaches the island shore (Woodroffe and Biribo, 2011). The reef structures promote the refraction and diffraction of this residual wave energy and critically influence the propagation behavior of waves on reef surfaces (Mandlier and Kench, 2012). As a consequence, such planform wave processes create low energy wave convergence zones (or nodal zones), favorable for sediment deposition (Flood, 1986; Gourlay, 1988; Kench and Brander, 2006a).

Studies focusing on a three dimensional approach of wave transformations have been demonstrating that the location and stability of low-lying carbonated reef islands are closely related to nodal zones on reef platforms (Flood, 1986; Gourlay, 1988; Kench and Brander, 2006a; Mandlier and Kench, 2012; Mandlier, 2013). For example, changes in the direction of the incident wave can produce a change in the position of the nodal point and a re-orientation of reef islands shorelines (Flood, 1986). Thereby, seasonal variations of reef islands morphology are expected to occur in response to seasonal variations in wave characteristics (Kench et al., 2009a, 2009b), showing the inherently sensitive of reef islands to changes in boundary conditions.

As a result to the dynamic nature of reef islands and their typically low elevation $(<3 \mathrm{~m}$ above mean sea level), there is significant global concern over their physical vulnerability in response to climatic change including sea-level rise and increased storminess (McKoy et al., 2010). Recent observations reports that the rate of global mean sea level rise during the 21st century will exceed the 1971-2010 rate for all representative concentration path-way (RCP) scenarios (Church et al., 2013), reinforcing the urgency of assessing their vulnerability to this aspect of climate change (Woodroffe, 2008). Much of the concern about accelerating sea level centers on the question of whether reef islands on atolls will be lost through erosion and flooding in future decades (Forbes et al., 2013).

One of the effects of sea level rise is to create deeper water over reefs and lagoons, potentially allowing larger waves, with possibly a different wave period to that of the 
locally generated wind waves, to reach reef island shorelines (Baldock et al., 2014). Storlazzi et al. (2015) show that waves will synergistically interact with sea-level rise, doubling the forecast of land flooding for a given value of sea-level rise when wavedriven water level is accounted. On the other hand, studies also shows that reef islands are morphologically resilient landforms that can increase in area despite sea-level rise and that island erosion should be considered as one of a spectrum of geomorphic changes possible to occur (Webb and Kench, 2010). Using analytical models (Mandlier and Kench, 2012) demonstrated that changes in water depth (a surrogate for increased sea level) and wave period may promote change in island position on reef surfaces due to the migration of wave convergence points.

Despite the overall recognition of the importance of planform wave process on reef island stability, few studies attempted to assess the effects of sea level rise on the refraction pattern over reef surfaces. Third-generation wave models numerically solved the wave action conservation equations (Booij et al., 1999; Sørensen et al., 2004) which includes depth- induced wave processes as refraction, shoaling, dissipation by bottom friction and breaking. They have been extensively used for wave propagation in coastal regions (Allard et al., 2008; Dan et al., 2011; Pattiaratchi et al., 2009; Stone et al., 2005), including applications on coral reef environments (Baldock et al., 2014; Filipot and Cheung, 2012; Golshani et al., 2012; Hoeke et al., 2013b, 2011; Lowe et al., 2010; Storlazzi et al., 2011; Vitousek et al., 2007) and atolls (Hoeke, 2010; Sato and Yokoki, 2010; Storlazzi et al., 2015). One of the advantages in using numerical models is the possibility to create hypothetical scenarios to evaluate changes in sea level and wave characteristic according to modifications in boundary conditions for complex topographies.

Through a combination of in situ data and numerical modelling, this chapter aims to study the refraction pattern and wave energy distribution on Rocas Atoll; a small shallow lagoon atoll located at the South Atlantic Ocean. A detail description of its topo-bathymetry is included and input to the numerical model in order to reproduce the effects of local morphological features, such as reef passages and sand aprons, on wave refraction. The wave propagation for current conditions and under sea level rise scenario is compared and its implications on reef islands morphology are discussed.

\subsection{Methods}

\subsubsection{Topographic and bathymetric surveys}

To represent the complex topography of the atoll, topographic surveys were conducted using a dual-frequency kinematic Global Position System (GPS). The instrument consisted of two GPS receivers, one serving as a base station (Trimble 5700 ) that remained at a fixed position throughout each of the surveys, and the other as a rove unit (Trimble R4) taken to individual measurement points. A geodetic 
benchmark (survey mark) on Farol Island was used as the reference point for the base station. Surveys at the exposed parts of the atoll, such as the reef rim and the reef islands, were conducted by foot during low tides using the rover GPS equipment mounted in a backpack kit. The lagoon was surveyed by coupling the rover unit with a Garmin echosounder installed in a monohull vessel. The measurements were done along equally spaced profiles (100 m) during high tides. The GPS surveys were carried out as post-processed kinematic surveys (PPK GPS), where positional data from the roving GPS was processed with the help of data from the stationary base GPS using the TBC software (horizontal and vertical accuracy of $\pm 20 \mathrm{~mm}$ ) (Figure 5.1). The bathymetry of offshore waters was gathered from Brazilian Navy nautical charts numbers 5101 and 5102. The in situ surveyed data were tidally corrected and the vertical datum of both sources (in situ and nautical charts) was adjusted to the Rocas Atoll Mean Low Water Spring (MLWS) provided by the Brazilian Navy.

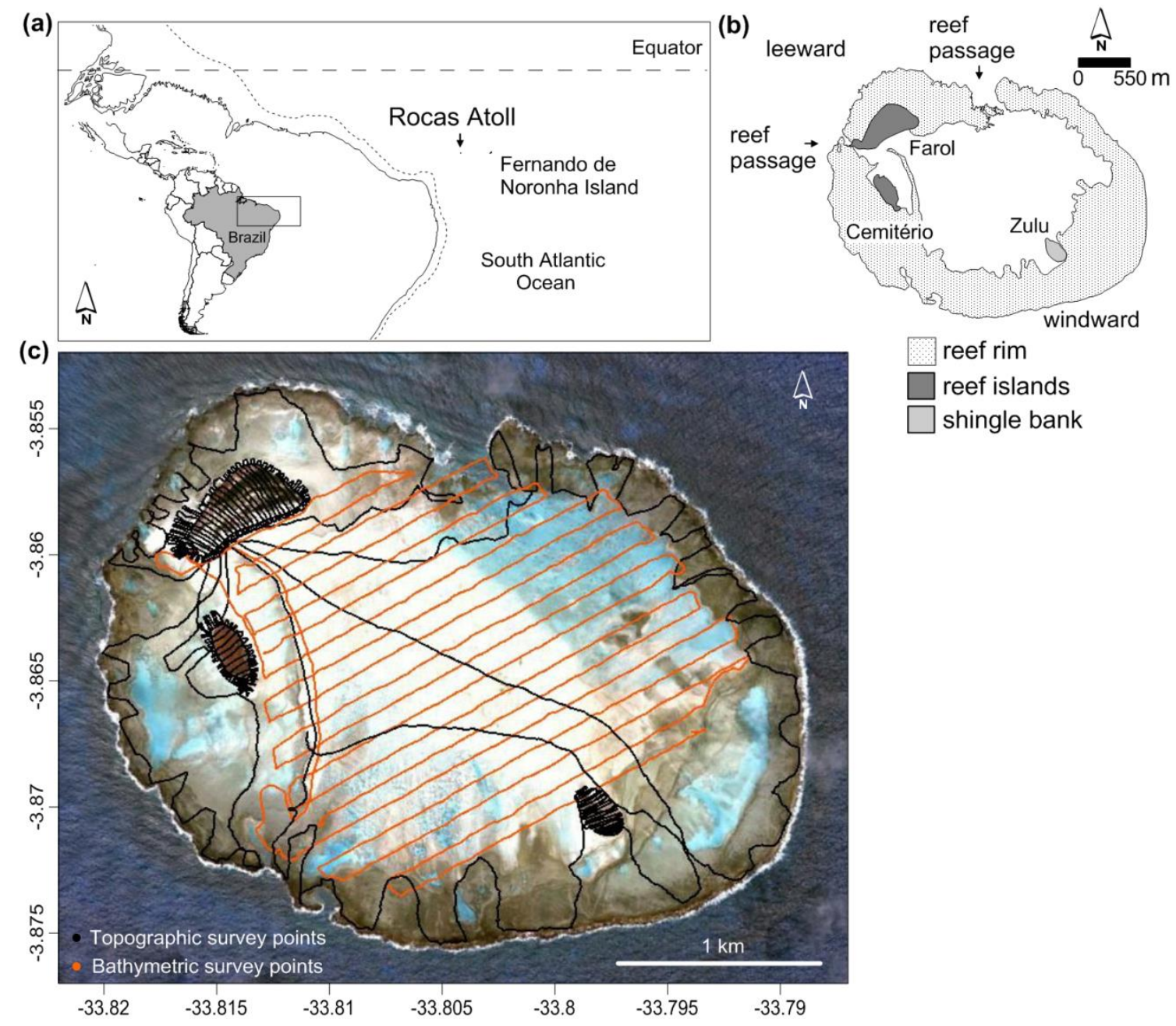

Figure 5.1. (a) Location of Rocas Atoll. (b) Description of Rocas Atoll. (c) Bathymetric and topographic survey points for the lagoon, reef islands, shingle bank and reef rim. Black dots represent the survey track for the dry parts of atoll using the rover on a backpack kit during low tides. Orange dots represent the survey track for the lagoon and sand apron using the rover coupled to an echosound on a monohull vessel during high tides. 


\subsubsection{Numerical wave model}

A numerical wave propagation model (MIKE21 SW) was implemented on Rocas Atoll to simulate incoming waves over the atoll's complex bathymetry. MIKE21 SW represents a third-generation spectral wave model that solves the wave action conservation equation using a parameterization of the zeroth and first-order moments of the wave action spectrum in the frequency domain (Holthuijsen et al., 1989). The model estimated the transformation of incident wave energy by shoaling, refraction, diffraction, and dissipation by both depth-induced wave breaking and bottom friction (Sørensen et al., 2004). The model settings including the mesh resolution were based on the successful setup described in Chapter 2. Details of model calibration and validation are also described on Chapter 2. In summary, an unstructured nested mesh with three different resolutions was created to solve the differences in the bathymetric scale along the model domain. The finer grid encompassing the atoll structure and the surrounding waters above approximately $20 \mathrm{~m}$ were refined to approximately $20 \mathrm{~m}$ spatial resolution. The high resolution in situ surveyed topobathymetric data were used to represent the complex topography of the atoll. Bathymetric data of the offshore deep waters $(>3000 \mathrm{~m})$ and the waters over the submerged mountain $(20 \mathrm{~m}$ to $70 \mathrm{~m})$ were gathered from Nautical Charts, and represented by a coarser grid.

Offshore wave characteristics used as boundary input to force the wave model were based on the global wave generation model WaveWatch III (NOAA) wave climate analysis for Rocas Atoll (Chapter 2).Table 5.1 contains a summary of dominant wave condition used to force the wave model. They represent the southeastern trade winds waves and the northern and southern swell conditions incident on Rocas Atoll. Each of these three wave conditions were simulated for the present sea level (scenario $S L R=0$ ) and for $1 \mathrm{~m}$ of sea level rise (scenario $S L R=1$ ).

Table 5.1. Summary of offshore dominant wave conditions on Rocas Atoll used to construct the wave propagation scenarios.

\begin{tabular}{ccccc}
\hline Scenarios & Incident wave condition & $\mathrm{Hs}(\mathrm{m})$ & $\mathrm{Tp}(\mathrm{s})$ & Dir (deg) \\
\hline Scenario 1 & & & & \\
$\mathrm{SLR}=0$ & Northern swell & 2 & 14 & 0 \\
$\mathrm{SLR}=0$ & Southern swell & 2 & 14 & 180 \\
$\mathrm{SLR}=0$ & Southeastern wind wave & 2 & 8 & 135 \\
Scenario 2 & & & & \\
$\mathrm{SLR}=1$ & Northern swell & 2 & 14 & 0 \\
$\mathrm{SLR}=1$ & Southern swell & 2 & 14 & 180 \\
$\mathrm{SLR}=1$ & Southeastern wind wave & 2 & 8 & 135 \\
\hline
\end{tabular}


Model outputs of significant wave height $\left(H_{s}\right)$ and peak wave period $\left(T_{p}\right)$ from the finer grid were used to calculate the wave power $(P)$ distribution over the atoll using the expression:

$$
P=\frac{\rho g^{2} H_{S}^{2} T_{p}}{32 \pi}
$$

where $\rho$ is the water density $\left(1027 \mathrm{~kg} / \mathrm{m}^{3}\right)$ and $g$ is the gravitational acceleration. From equation (1), it is possible to quantify the synergy of wave height and period providing an estimation of wave dissipation over the atoll. Comparisons of directional wave vectors were used to assess the wave refractions changes on each scenario.

\subsection{Results}

\subsubsection{Atoll topography}

The surveyed morphology of Rocas Atoll is shown in Figure 5.2. Rocas is located in the western portion of a seamount with surrounding waters having an average depth of 25 $\mathrm{m}$ and shelf-break depth of approximately $50 \mathrm{~m}$. The highest point on the atoll is $5.2 \mathrm{~m}$ above MLWS, located in the northwest side of Farol Island. The deepest point is $7.8 \mathrm{~m}$ below MLWS, located in the Barretão passage. The entire atoll is flooded during spring high tide, except Farol and Cemitério Islands and some reef boulders located in the windward portion of the atoll. The following morphological components may be identified to facilitate the topo-bathymetric description: reef rim, reef passages, lagoon, reef islands and shingle bank. 

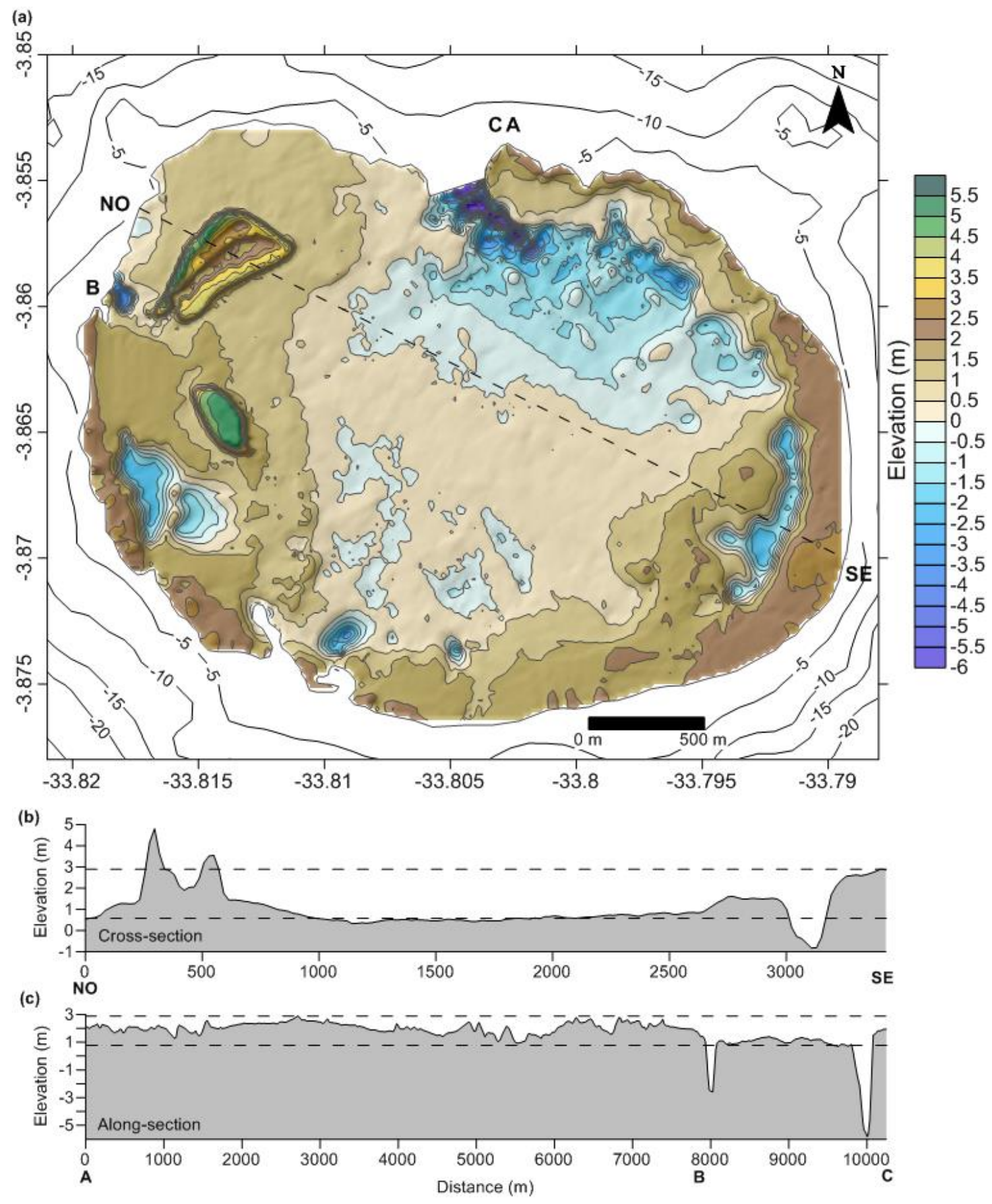

Figure 5.2. (a) Digital elevation model of Rocas Atoll. (b) Profile section from the leeward side (NW) to the windward side (SE). (c) Profile section of the reef rim perimeter (A to C); letter B correspond to Barretinha passage. Note: the reef boulders and the submerged depressions on the reef rim were not detailed in the survey.

Reefrim

The atoll edge is noticeably not topographically uniform, with a difference of up to 2.1 $\mathrm{m}$ between the windward and leeward sides. The northwestern portion (leeward), between the Barretão and Barretinha passage is lower than the rest of the atoll. The mean height of the reef flat in this section is $1.3 \mathrm{~m}$, whereas the remainder of the rim 
is at about $2.5 \mathrm{~m}$. The highest point of the edge is located on the sotheastern side (windward), at $2.9 \mathrm{~m}$. Hundreds of reef boulders of varying sizes and exclusively found on the windward side and dozens of submerged depressions (e.g., small pools) spread across the edge are prominent features of the reef rim. The largest boulder (known locally as "Pedra do Guarapirá" or "frigatebird stone" in English) stands out because it is approximately $6 \mathrm{~m}$ high and remains emerged during the highest high tides.

\section{Reef passages}

The reef rim is cut by two reef passages, both located on the leeward side. The larger reef passage (Barretão) is connected to the lagoon during all tidal stages and has an average depth of $6 \mathrm{~m}$. The passage is $300 \mathrm{~m}$ wide and $500 \mathrm{~m}$ long. Conversely, the smaller reef passage (Barretinha) is separated from the lagoon during the low and intermediary tides by sand aprons that connect both reef islands (Farol and Cemiterio). It has an average depth of $3 \mathrm{~m}$ and is $30 \mathrm{~m}$ in length and $70 \mathrm{~m}$ in width.

\section{Lagoon}

The lagoon is small and shallow, with an average depth of $3 \mathrm{~m}$. During low tide, the water volume is restricted to the northern portion, near Barretão passage. It may then be divided into a perennial lagoon and an intermittent lagoon, according to their exposure characteristics during the tidal cycle. The portion of the lagoon emerged during low tide, or intermittent lagoon, consists of an extensive sand apron that isolates the reef islands from the perennial lagoon. The average depth of that body is 2 $\mathrm{m}$ during high tide. Conversely, the perennial lagoon has an average depth at high tide of $4 \mathrm{~m}$ and an average depth at low tide of $2 \mathrm{~m}$.

\section{Reef islands and shingle bank}

The reef islands are located on the leeward reef rim between the two reef passages. The reef flat on which they are is about $1.5 \mathrm{~m}$ from the MLSW. The vegetated island surface ranges from $2 \mathrm{~m}$ to $3.7 \mathrm{~m}$ above the reef flat surface and $3.5 \mathrm{~m}$ to $5.2 \mathrm{~m}$ above the MLWS. The two islands differ in their planform morphologies. Farol is horseshoeshaped with a series of asymmetric low-elevation ridges and a central depression. The oceanward ridge is higher than the lagoonward ridge by approximately $1.7 \mathrm{~m}$. Cemitério Island has an elongated planform shape with a flat top, marked by a slight difference of $0.5 \mathrm{~m}$ between the oceanward ( $5 \mathrm{~m}$ above MLWS) and lagoonward edge (4.5 $\mathrm{m}$ above MLWS). Zulu shingle bank is located on the windward reef flat with $1.1 \mathrm{~m}$ above MLWS. It has an elongated-shape with its top reaching up to $2.4 \mathrm{~m}$ above MLWS. A detailed description of the reef islands and the shingle bank morphology is presented in Chapter 4. 


\subsubsection{Overall wave refraction}

\section{Present condition $(S L R=0)$}

Wave power across the atoll ranged between 0 and $25.8 \mathrm{~kW} / \mathrm{m}$ for the SLR=0 scenario. Compared to offshore conditions, wave power at the lagoon is at least two orders of magnitude lower for any incident wave condition. At the reef edge, where the wave dissipation starts, the wave power is one order of magnitude lower than offshore (Figure 5.3a, c, e).

Wave vectors distribution demonstrates that the atoll wave refraction pattern is highly affected by the larger reef passage (Figure 5.3a, c, e). Despite this passage being oriented northwards (leeward side), which provides favorable conditions for the penetration of northern swells into the atoll lagoon, both southern and southeastern offshore waves refract around the reef rim and also penetrate through this passage into the lagoon. As a result, highest values of wave power are found near this entrance for all incident wave condition. This passage, together with the lagoon topography, also controls the position of wave vectors convergence and interference on the atoll. During high tides, waves converge from the center of the lagoon to the leeward and windward sides of the reef rim, represented by the zone where wave vectors coming from opposite directions converge. At the leeward side, the vectors convergence coincides with the reef islands location. In turn, the wave vectors that penetrate into the lagoon through the reef passage converge with incident and refracted waves on the windward side. An interference zone of wave vectors, characterized by the aligning of wave vectors from different directions, is observed behind the windward convergence zone and near the Zulu shingle bank.

Results of model simulation for different incident wave conditions (northern and southern swell and southeast wind waves) show small modifications on the wave refraction pattern across the atoll. The position of wave vector convergence and interference zones are very similar for southern swell and southeastern wind wave conditions, and is slightly dislocated to the south during northern swell condition. In contrast, differences in the wave power were observed according to incident wave characteristics. Highest wave power values in the lagoon and in the reef rim were observed during northern swell. As shown by the morphology (Figure 5.2), the elevation of the leeward reef rim is about $2 \mathrm{~m}$ lower than the windward reef rim. Thereby, offshore waves incoming from this side, are less dissipated on the reef edge and can propagate into the lagoon with higher energy. This is also facilitated by the larger reef passage at this side. Wind waves incoming from the southeast result in less energetic conditions in the lagoon and at the leeward side. In turn, southern swell results in intermediate wave power magnitude. They are more intensively refracted on the reef rim than wind waves and reach the leeward side with more energy. 


\section{Sea level rise condition (SLR=1)}

Results show an overall increase in the wave power across the atoll on the $S L R=1$ scenario (Figure 5.3b, d, e) with wave power ranging between 0 and $38.5 \mathrm{~kW} / \mathrm{m}$. The $\mathrm{SLR}=1$ also results in changes on the refraction pattern, especially on the windward side of the atoll. The wave vectors do not converge on the center of the lagoon and at the windward side, as for $S L R=0$. Instead, a marked interference zone is formed in the windward side with waves from south and southeast propagating to the leeward side. For northern wave condition, the lagoon convergence zone is dislocated southward. However, wave vectors still converge on the leeward side due to wave refraction at the reef edge and it penetration through the reef passage. Nevertheless, this passages imposes less influence on wave refraction than observed for $S L R=0$ scenario. Thereby, it allows lagoonward wave propagation with less dissipation, contributing to set the wave vector convergence on the leeward side for all incident wave condition. 

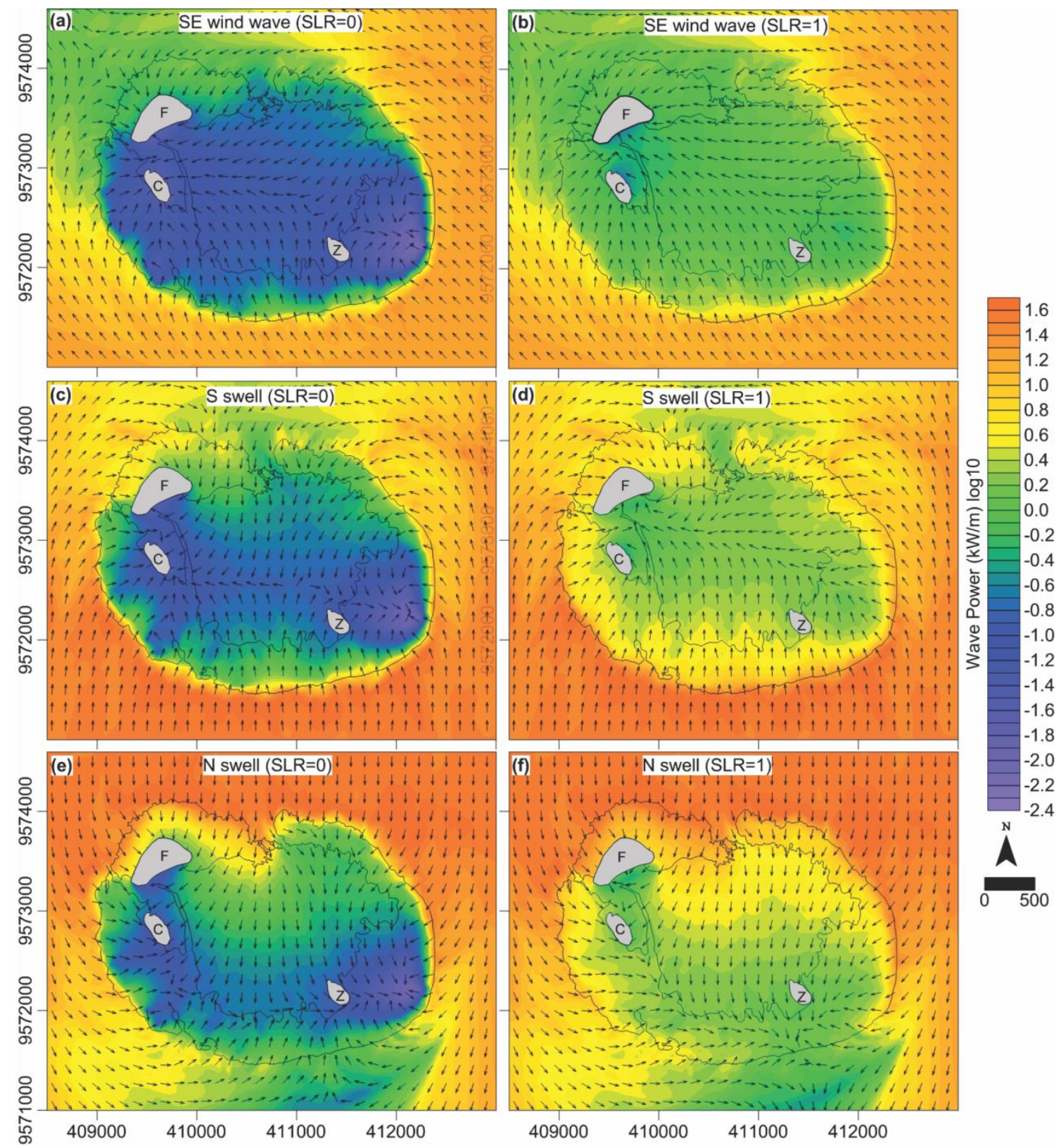

Figure 5.3. Distribution of wave power $P(\mathrm{~kW} / \mathrm{m})$ on Rocas Atoll for north southeast wind wave condition (a) $S L R=0$ and (b) $S L R=1$; south swell wave condition (c) $S L R=0$ and (d) $S L R=1$; and north swell wave condition (e) $S L R=0$ and (f) $S L R=1$; Data is present in logarithmic scale to show details of $P$ distribution on shallow waters. Linear values of $P$ are display besides the logarithm scale. Letters on map correspond to Farol islet (F), Cemitério islet (C) and Zulu shingle bank $(\mathrm{Z})$ locations. Wave vectors are not scaled.

\section{Spatial and temporal wave window action}

The $S L R=0$ scenario was simulated for high, intermediary and low tide conditions to evaluate spatial and temporal wave characteristics variations along a tidal cycle. Results show that $\mathrm{Hs}$ and $\mathrm{Tp}$ are strongly modulated by tide. As the tide drops, attenuation of $\mathrm{Hs}$ and $\mathrm{Tp}$ increases (Figure 5.4) and the wave action field is restricted to the perennial lagoon (Figure 5.5). During low tides, Hs is attenuated by $91 \%$ whereas $\mathrm{Tp}$ is attenuated by $75 \%$. At this tidal stage and at a part of intermediary tide stage, the 
sand apron becomes exposed. The reef islands are only affected by wave action close to high tide, when the water level reaches their surroundings. This corresponds to a temporal window of $5 \mathrm{~h} 40 \mathrm{~min}$ at each $12 \mathrm{~h} 25 \mathrm{~min}$ semidiurnal interval, which is about $46 \%$ of a tidal cycle. On the SLR=1 scenario, the temporal window of wave action on the reef islands increases to $57 \%$ of a tidal cycle.
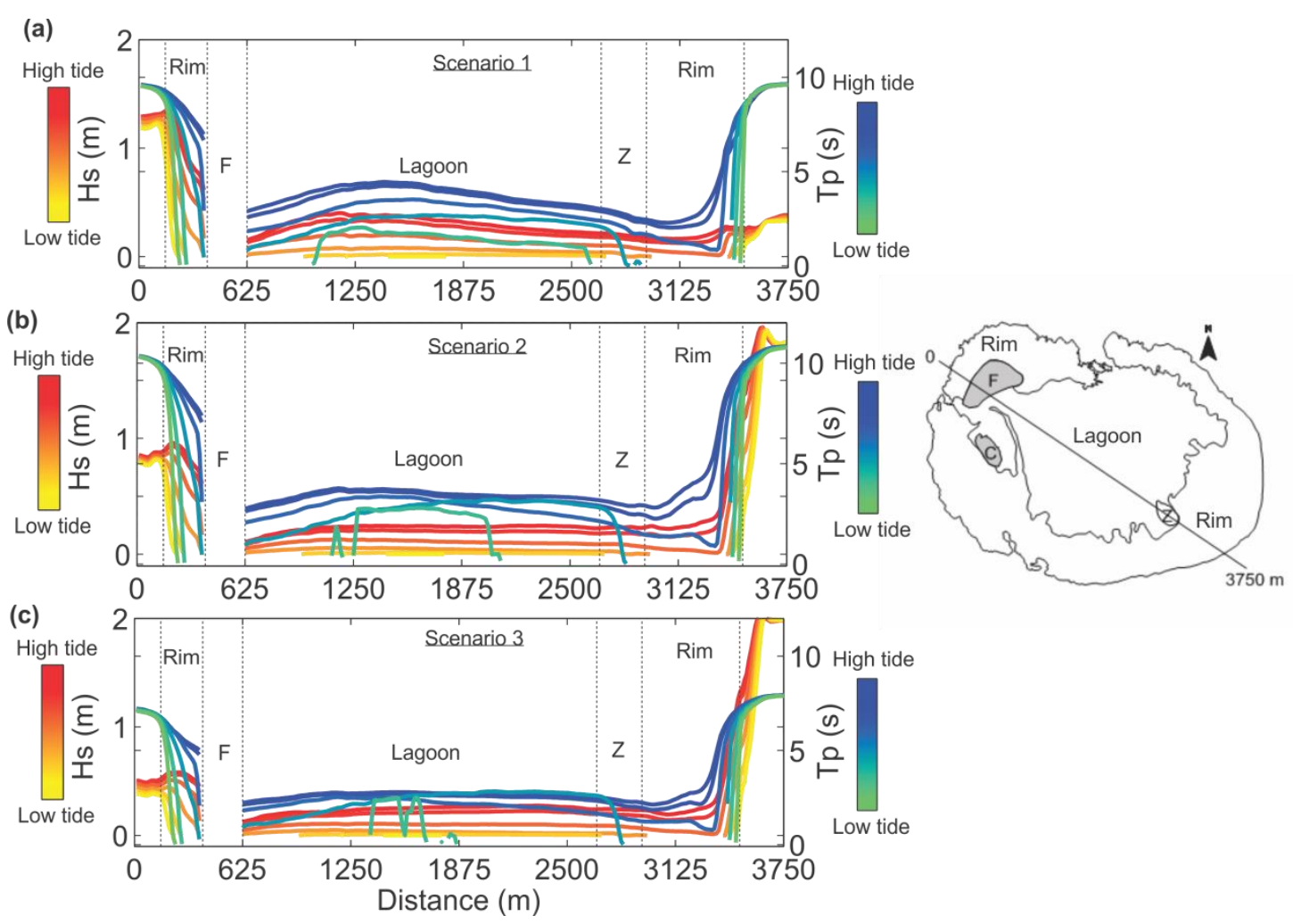

Figure 5.4. Cross-profile of significant wave height (Hs) and peak wave period (Tp) from the leeward to windward over a tidal cycle for the SLR=0 scenario. (a) Northern swell condition, (b) southern swell condition and (c) southeastern wind waves. Vertical lines indicate the reef rim (Rim), Farol Island (F), lagoon (Lagoon) and Zulu shingle bank (Z) limits. 


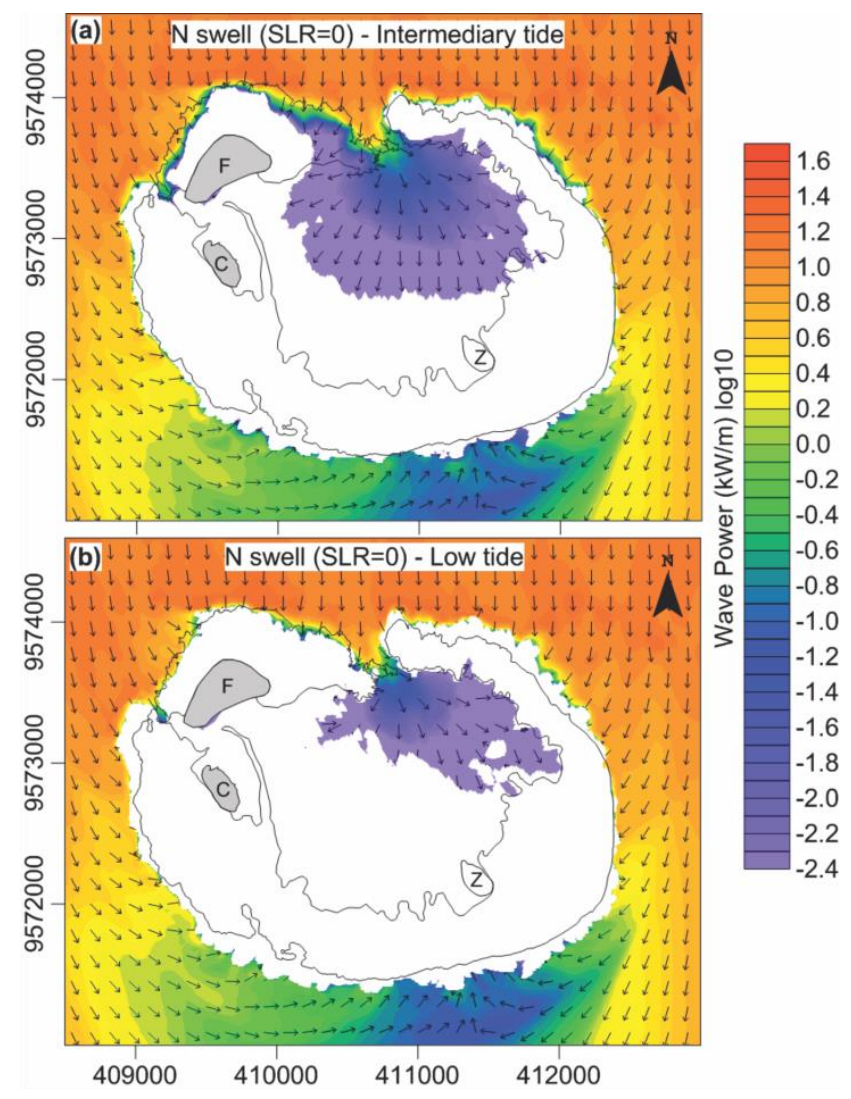

Figure 5.5. Spatial wave window action during (a) intermediary and (b) low tide.

\subsubsection{Wave vectors convergence}

The convergence of wave vectors at the leeward of the atoll, where the reef islands are located, is shown in detail in Figure 5.6 and Figure 5.7 for $S L R=0$ and $S L R=1$, respectively. Model simulations show that wave vectors converge at the center of Cemitério Island and near the lagoonward side of Farol Island for the SLR=0 (Figure 5.6). The oceanward beach of this island, which is farther from the convergence line, is also subject to more energetic waves when compared to others beaches from both islands, especially during northern swell. Offshore waves from south and southeast are refracted on the reef rim and reach the oceanward side of Farol Island from the west, reaching the shoreline at about $110^{\circ}$. For northern offshore waves, less refraction is observed and waves reach the oceanward beach with an angle of $70^{\circ}$ to the shoreline. In contrast, the lagoonward beach of this island is less exposed to incident energetic waves. Average wave power on this beach is about $67 \%$ lower than the oceanward beach. Waves reach the shoreline almost perpendicular during offshore southern and southeastern conditions and with an angle of $45^{\circ}$ during northern wave condition. The difference of $\mathrm{Hs}$ and $\mathrm{Tp}$ magnitudes that reach the both sides of Farol Island is also shown in Figure 5.4. Contrasting, beaches at the Cemitério Island do not show a significant difference in incident wave energy, except during northern swell when its lagoonward beach receives more wave energy than its oceanward beach. 
For all three incident wave conditions for the $S L R=1$ scenario, model simulations demonstrates a slight displacement on the wave vectors convergence at the Farol Island location and virtually no changes on the Cemitério Island location (Figure 5.7). The direction of the displacement is related to wave period (swell or wind wave) instead of its offshore direction. Results show that offshore incident swell (from north or south), induced a vector convergence displacement towards the lagoon, while offshore incident wind waves induced a displacement towards the reef edge. Wave vectors are moved lagoonward by 73 and $33 \mathrm{~m}$, for northern and southern swell wave conditions, respectively. For wind waves, wave vectors are moved $28 \mathrm{~m}$ oceanward. Table 5.2 contains a summary of wave vector location and displacements on SLR=0 and $\mathrm{SLR}=1$ scenarios for each incident wave condition.

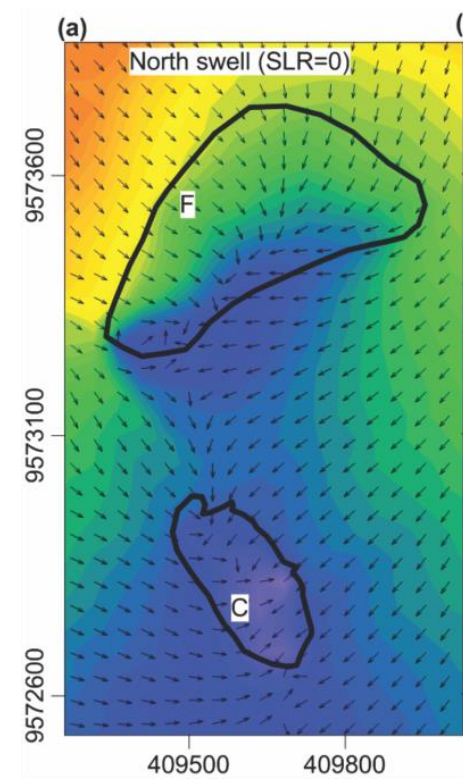

(b)

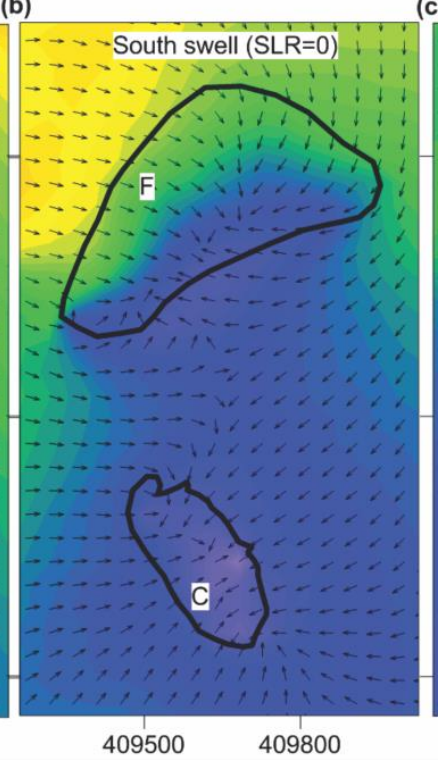

(c)

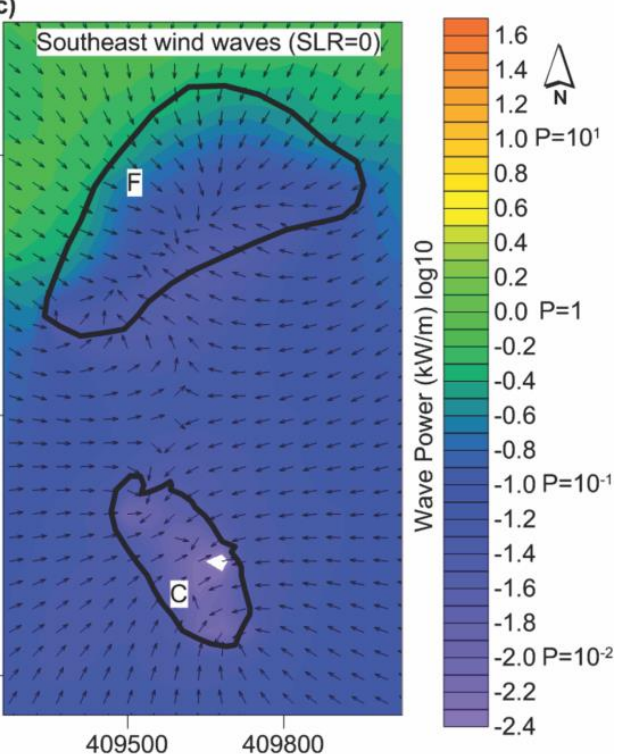

Figure 5.6. Details of wave vectors at the reef islands location. Letters on map correspond to Farol Island (F), Cemitério Island (C). Letters on map correspond to Farol islet (F), Cemitério islet (C). Wave vectors are not scaled. 

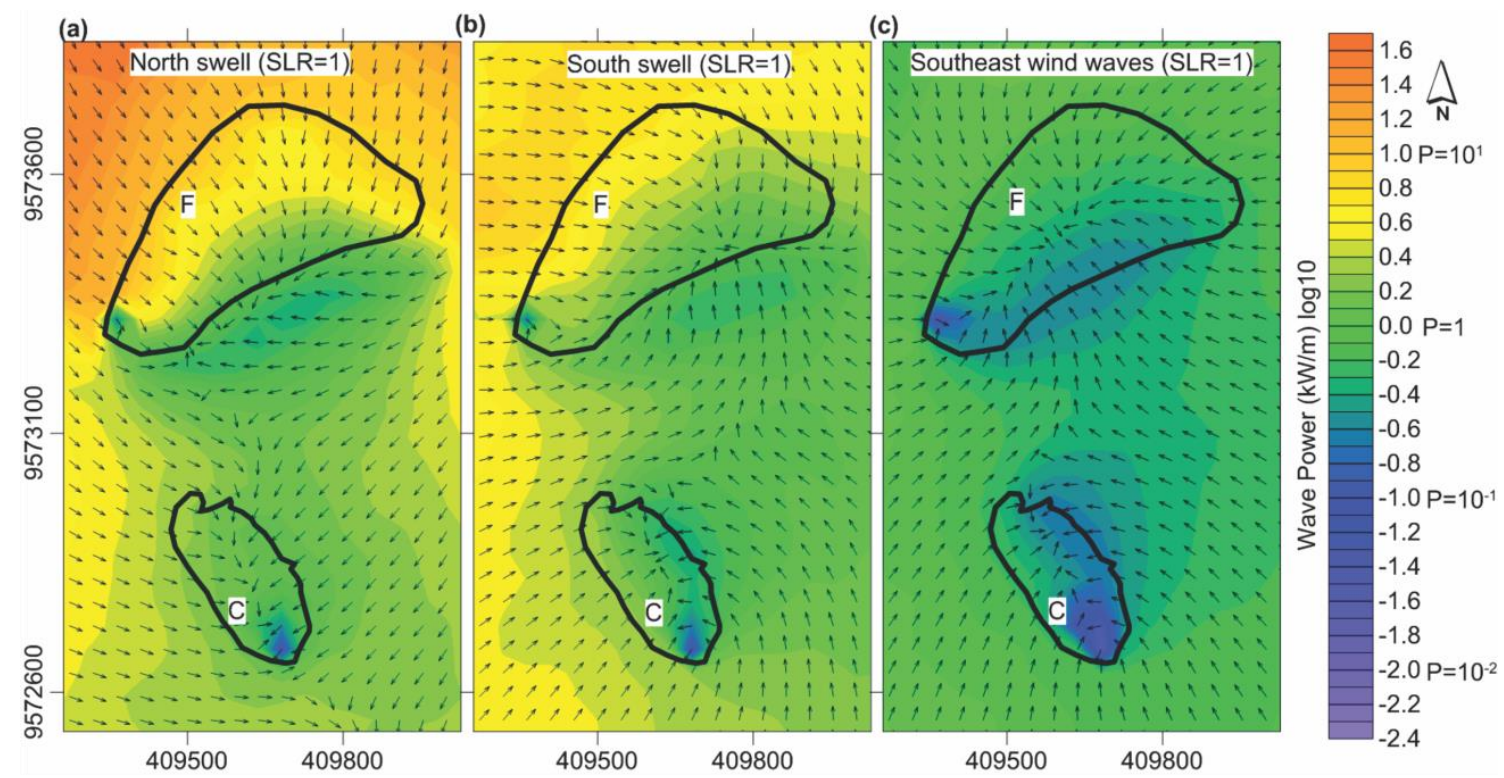

Figure 5.7. Details of wave vectors convergence at the reef islands location. Letters on map correspond to Farol Island (F), Cemitério Island (C). Wave vectors are not scaled.

Table 5.2. Summary of wave vector convergence location and displacement on SLR=0 and $S L R=1$ scenarios for each incident wave condition.

\begin{tabular}{|c|c|c|c|}
\hline \multirow[b]{2}{*}{ Wave vector convergence position } & \multicolumn{3}{|c|}{ Wave Condition } \\
\hline & $\begin{array}{l}\text { Northern } \\
\text { swell }\end{array}$ & $\begin{array}{l}\text { Southern } \\
\text { swell }\end{array}$ & $\begin{array}{l}\text { Southeastern } \\
\text { wind waves }\end{array}$ \\
\hline scenario $1(S L R=0)$ & & & \\
\hline Distance from Oceanward shoreline (m) & 220.41 & 219.81 & 185.65 \\
\hline $\begin{array}{l}\text { Distance from Lagoonward shoreline }(\mathrm{m}) \\
\text { scenario } 2(S L R=1)\end{array}$ & 35.59 & 36.19 & 70.35 \\
\hline Distance from Oceanward shoreline (m) & 293.44 & 253.59 & 157.56 \\
\hline $\begin{array}{l}\text { Distance from Lagoonward shoreline }(\mathrm{m}) \\
\text { scenario } 1 \text { - } 2\end{array}$ & 30.54 & 2.41 & 98.44 \\
\hline Displacement $(\mathrm{m})$ & 73.03 & 33.78 & -28.09 \\
\hline Displacement direction & Lagoonward & Lagoonward & Oceanward \\
\hline
\end{tabular}

Results show an increase in wave power heterogeneity around the reef islands with rising sea level ( $S L R=1$ scenario). Average wave power reaching the oceanward beach of Farol Island increases $84 \%$ for northern swell condition, $65 \%$ for southern swell condition and $52 \%$ for southeastern wind waves condition. At the lagoonward, in turn, average wave power has a higher increase for southern swell condition (79\%), followed by southeastern wind waves $(69 \%)$ and northern swell $(24 \%)$ conditions. Lagoonward wave power increase is, thus, small compared to oceanward increase for northern swell condition, resulting in a larger displacement of wave vector convergence towards the lagoon. 


\subsection{Discussion}

\subsubsection{Atoll topography, wave refraction and reef islands distribution}

Despite being generally defined as mid-ocean annular reefs, enclosing a lagoon (Barry et al., 2007), there is a great variability in atoll sizes and shapes (Shimazaki et al., 2006; Stoddart, 1965). As shown in Figure 1.2, their size can range from more than 10000 $\mathrm{km}^{2}$ to less than one $\mathrm{km}^{2}$. In general, large atolls exhibit very different morphological characteristics of small atolls. They are normally composed by deeper lagoons (Wiens, 1962) which can comprises numerous small reef platforms (or table reefs) (Purdy and Winterer, 2001; Woodroffe and Biribo, 2011). In some cases, wind waves are generated on local wave fetch developed in the lagoon (Richmond, 1992) and swell energy can propagates through wide open reef rims (Andréfouët et al., 2001). These morphological ranges contribute to a wide variation on the wave propagation pattern in atolls.

Rocas fits to the small-sized atoll group, with a shallow lagoon and almost continuous reef rim interrupted only by two reef passages. Due to its morphology, results from model simulations show that Rocas is similar to an elliptical platform reef (e.g. Gourlay, 1988; Mandlier and Kench, 2012) in terms of wave refraction pattern. Wave vectors converge mainly on the leeward side and an interference zone can be observed from the windward side trough the lagoon. Thereby, such as observed for platforms reefs (Gourlay, 1988), Rocas structure acts both as an obstruction for blocking the transmission of wave energy and as a lens for focusing that energy.

However, our results show that the location of convergence zones is not only influenced by the wave direction and its interaction with the elliptical reef shape, but is also controlled by topographic variations of the reef structure. Particularly, the presence of a wide reef passage on the leeward margin has an important role on the wave refraction pattern of Rocas Atoll. For example, for either northern or southern swell, only slight variations on the convergence zones are observed. This passage affects the refraction process by allowing offshore waves from different directions to penetrate into the lagoon with less dissipation, thus, controlling the location of the convergence zone. This observation was possible through the model application based on the real atoll morphology to simulate the wave propagation. Previous studies on such processes are based on idealized elliptical morphology (with uniform depth and vertical reef faces (e.g. Gourlay, 1988; Mandlier and Kench, 2012; Meijer, 2014).

The reef islands distribution on Rocas are, in turn, closely related to the wave convergence zone location. Such islands are typical sand cays, defined as sedimentary deposits composed mainly of sands (Richmond, 1992) and found on lower energy or leeward margins (Stoddart and Steers, 1977). Often, this type of reef island occur in areas without disturbances such as tropical storms (McLean and Woodroffe, 1997). 
Rocas also exhibit a shingle bank on the windward side, as expected to occur on elliptical platforms (Gourlay, 1988; Mandlier and Kench, 2012). According to Gourlay (1988), this type of sedimentary deposit is formed from large pieces of reef material that are broken and displaced from the reef-edge during extreme meteorological events. The shingle bank location on Rocas corresponds to the zone of alignment of wave vectors from different directions. Unidirectional wave generated currents (Chapter 3) can be an important forcing in transport sediments from the other parts of the atoll, such as sand aprons and windward reef rim, to be deposited on wave convergences zones and are suggestions for further research.

\subsubsection{Sea level rise and wave vectors convergence displacement}

Wave attenuation is highly dependent on water depth over reefs (Costa et al., 2015; Hardy et al., 1991; Kench et al., 2006; Lugo-Fernández et al., 1998b). As a consequence, sea level rise is shown to increase the wave energy that is able to propagate onto the reef flats and lagoons reaching reef- protected shorelines (Baldock et al., 2014; Sheppard et al., 2005; Storlazzi et al., 2015). Although such processes are widely recognized, the effects of sea level rise on the wave refraction over reefs has been less investigated. Mandlier and Kench (2012) suggest that increases of water depth over the reef cause the location of wave convergence zones to migrate away from the windward reef margin.

Model simulations on Rocas show the displacement of convergence zone and larger wave energy with sea level rise. However, the direction of such displacement is more sensitive to the incident wave period rather than wave direction. Swell waves, either from north or south, tend to move the convergence zone lagoonwards, whereas wind waves tend to move it seawards. This can be explained by the larger refraction potential of longer waves on shallow water. In contrast, very short waves may propagate over a platform as intermediate or deep water waves, subsequently limiting or inhibiting the interaction with the submerged structure (Mandlier and Kench, 2012). Thereby, swell waves refracting on the elliptical reef rim results in more energy on the leeward margin of atoll. At the same time, they dissipate more energy propagating through the shallow lagoon than the wind waves. For the case of swell incidence, we observe a higher increase in wave energy on the oceanward side of Farol Island, when compared to its lagoonward side, displacing the convergence zone towards the lagoon. Wind waves, in turn, refract less on the reef edge and dissipate less energy propagating through the lagoon. The wave energy reaching Farol Island is higher on the lagoonward than at the oceanward, as illustrated by the model simulations (Figure 5.7). In this case, the displacement of the convergence zone is towards the reef edge (seaward). 


\subsubsection{Implications for reef island morphodynamics}

Wave convergence patterns and spatial variations in wave forcing gradients shown here, can be related to the morphological changes of reef islands atolls. Data presented in Chapter 4 shows substantial accretion on the Farol island and stability on Cemitério Island at a decadal time scale. The wave convergence zones coincide with the islands location, as discussed above. However, there is a difference in their mobility and in the wave energy on both locations. At the Cemitério islands, wave vectors show less variability in position for all incident waves and sea level scenarios. Moreover, this island is anchored by consolidated sediments that protect their beaches from direct wave impact (Chapter 4). These two factors can contribute to the morphological stability of this island, as described in Chapter 4. Conversely, Farol Island showed more complex morphological changes. This island is being accreted by almost three times its size during the last seven decades, changing from an elongated shape to a horseshoe shape, with a central depression (Chapter 4). The lagooward accretion was followed by oceanward erosion, representing net lagoonward migration. Also at both, seasonal and daily time scale, the Farol oceanward beach showed higher gross volume changes. Wave refraction results show that this side of the island is subjected to higher energetic wave conditions and higher sensitivity to incident wave direction and period (swell or wind wave). This may explain the high morphological variability of this island, as demonstrated in Chapter 4. Furthermore, for current sea level condition, wave vectors tend to converge in lagoonward of the island, creating depositional conditions.

The pattern of accretion accompanied by lagoonward migration, such as observed at the Farol Island has also been described in many Central Pacific atolls as one of a spectrum of geomorphic changes due to sea level rise (Webb and Kench, 2010). These authors demonstrate that $86 \%$ of 27 atoll islands remained stable or increased in area during the last decades. For the same period, sea level rise around these islands is estimated at $2 \mathrm{~mm} . \mathrm{yr}^{-1}$ (Webb and Kench, 2010). With rising water depth over the reef, larger waves can reach the oceanward shore of reef island promoting erosion (Sheppard et al., 2005; Sheppard, 2002; Storlazzi et al., 2015). The aggregated effect of ocean shoreline displacement and lagoon progradation is a shift in the nodal position of islands on reef surfaces (Webb and Kench, 2010). Wave model simulations on Rocas Atoll demonstrated changes on the convergence zones due to sea level rise. However, the direction of shift (toward the lagoon or toward the reef edge) is controlled by the incident wave period (swell or wind wave). Thereby, the results suggest that under sea level rise scenarios areas prone to sediment accumulation will become less stable. The relative frequency between swell and wind wave incidence will be an important driver of morphological change pattern on the reef islands. 


\section{Chapter 6}

\section{CONCLUNDING REMARKS}

The morphology of an atoll and the morphodynamics of the islands formed on the surface of its reef edge are related to the hydrodynamic regime to which the atoll is subjected (Shimazaki et al., 2004; Kench et al., 2006). Accordingly, reef islands reportedly tend to be located on the protected side of the atoll (leeward), that is, on the shore opposite to the dominant direction of wind incidence and, in turn, the dominant wave direction (Stoddart and Steers, 1977). In Rocas Atoll, the Farol and Cemitério reef islands are located on the northwest side of the atoll. They are mainly formed by medium to coarse sand sized sediments of carbonate origin (Pereira, 2010) whose source is the biogenic structure of the atoll itself.

The results from the wave climate analysis (Chapter 2) showed that the side exposed to constant wave action (windward) is opposite to the position of the islands, that is, the southeast side, which is the most energetic side. This condition is responsible for creating a wave energy gradient that declines from the exposed to the protected side (e.g. Kench et al., 2006), with implications for sediment transport. The coarser sediments, above the sand fraction, are transported from the exposed shore to the wave interference zone created due to the wave refraction process (Gourlay, 1988). The sand and gravel sized sediments continue to be transported to the focal area of refraction in which they are deposited, forming the reef islands (process also described by Gourlay, 1988; and Mandlier, 2013). Furthermore, the presence of a surf zone on the exposed side promotes the constant breaking and displacement of pieces of reef structure (Gourlay, 1988). The exposed side only promotes the deposition of the coarser material displaced from the exposed edge because it has a high potential for sediment remobilization (e.g. Woodroffe et al., 1999). Conversely, the protected side has a small sediment remobilization potential and is formed by the finer material derived directly from the edges and from the lagoon (Woodroffe et al., 1999). This process not only explains the position of formation of the Farol and Cemiterio Islands in the atoll but also the formation of Zulu bank, located in the exposed (windward) shore and basically formed by sediments of very coarse sand fraction and sand granules (Pereira, 2010).

Furthermore, results from Chapter 3 demonstrate that the predominant current direction is SE-NW in both reef channels and the lagoon. This current is also induced by waves, that is, the breaking of waves on the exposed side creates a water stack (wave set-up) on that side, which is forced to flow into the protected side due to the generated pressure gradient, in addition to the energy gradient caused by the wave refraction. The wave-induced flow in semi-closed atolls tends to be unidirectional 
(Callaghan et al., 2006). We observed the same process in Rocas Atoll. However, since Rocas is under a mesotidal regime, a clear modulation of tidal currents speed and direction can be observed. The current direction has a bimodal function, predominantly flowing out of the atoll during $73 \%$ of a tidal cycle, particularly in Barretão passage. However, during the remaining $27 \%$ of the time, the current flows into the atoll. Therefore, sediment transport, albeit preferably outward, experiences variations in intensity and direction, affecting the resulting overall transport. At Barretinha passage, sediment transport occurs northwesterly (out of the atoll) during all tidal stages, except during slack water.

It is noteworthy that the hydrodynamic processes and their relationship with waveinduced sediment transport depend on the reef rim morphology (Chapters 2 and 3). The waves have a significant effect on the total flow and sediment distribution because the Rocas Atoll has uninterrupted rim, being only cut by two channels (Barretão and Barretinha), as discussed above. The flow inside atolls with wide openings on the rim, which are deep compared to the height of waves and the tidal range, will mainly be generated by tides, and the water level of the lagoon will oscillate according to their amplitude (Callaghan et al., 2006).

Thus, sediment transport in Rocas Atoll is wave-induced and tidally-modulated, with the main flow from SE to NW. Farol and Cemitério Islands, on the protected shore, are formed by the deposition of sediments derived from the breakdown of material from the reef edge and lagoon, whereas Zulu bank, on the exposed shore, is formed by edge material. Barretinha passage is the main escape route of atoll sediments because it is located close to sandy deposits and flows out of the atoll with high current speeds. However, seasonal variations may occur, according to the wave climate, attenuating the sediment exit through this passage. As shown in the results, the $\mathrm{N}$ and NW swells may generate a significant flow in the opposite direction to the dominant flow, directing the sediments scattered around the reef rim from the protected shore and around the Barretinha passage into the atoll. Sediment accretion was observed at Farol Island for $\mathrm{N}$ and NW waves.

Thus, there is a significant seasonality in gain and loss at the NW side of Farol Island because of the wave climate (Chapter 4), whereas in the same study period, the SE side remained stable. The combination of the long-term evidence of erosion at the NW side and the accretion of the SE side, shows the medium to long-term net erosion on the NW side, despite the marked seasonal pattern, whereas the resultant impact on the SE side is net accretion. This morphological evolutionary model of Farol Island fits into the rollover class reported by Woodroffe et al. (1999), which describes reef islands with a migration towards the lagoon. In this case, the side facing the ocean experiences erosion, whereas the side facing the lagoon experiences continuous accretion. Results also suggests a current stage of decelerating accretion of Farol 
island, given the small daily and seasonal net morphological changes observed at Chapter 4 (Figure 6.1).

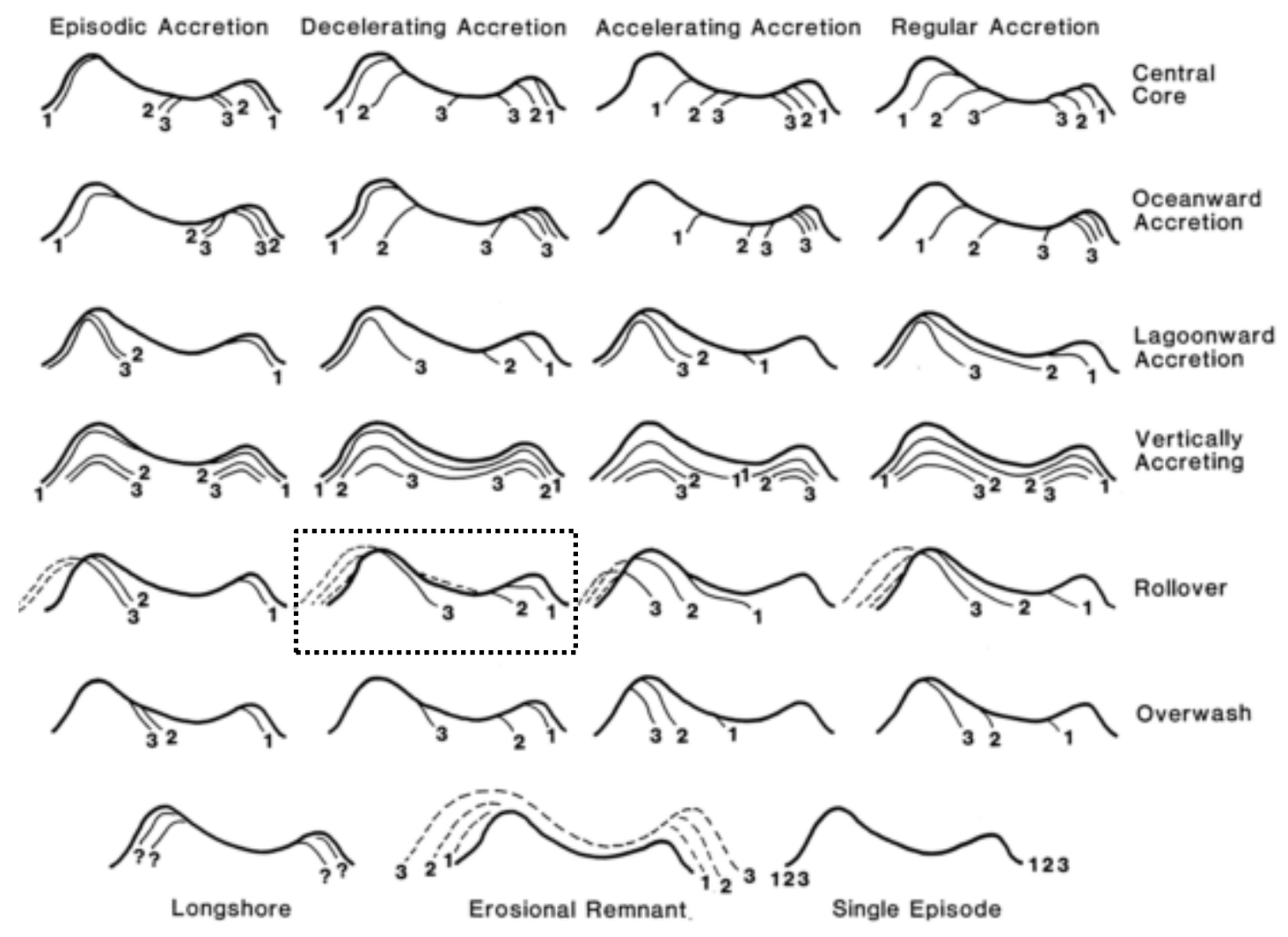

Figure 6.1. Evolution models of reef islands (Woodroffe et al., 1999). In each model, the left sides represent the sides facing the ocean (oceanward), and the right sides represent the sides facing the lagoon (lagoonward). The dashed box indicates the model into which Farol Island fits.

Such pattern of morphological evolution, with the migration of a reef island towards the lagoon, was also observed in most reef islands in the Central Pacific studied by Webb and Kench (2010). According to these authors, this pattern may be related to sea level, which causes sedimentary reorganization due to changes in the wave energy convergence zones. In other words, the water column increase on the reef edge reduces wave energy attenuation and changes in refraction. Thus, the side of the islands facing the ocean will receive more energy, inducing its migration towards the lagoon.

Furthermore, it has been also demonstrate the most of reef islands in the Central Pacific has increase in area despite the rise rate of $2 \mathrm{~mm} . \mathrm{yr}^{-1}$ in the sea level (Webb and Kench (2010). In cases of significant area increases, the erosion on the side facing the ocean may be offset by a large increase in the side facing the lagoon, which should occur through additional sediment inputs into the system (Webb and Kench, 1999). In the case of Rocas Atoll, Farol Island showed a substantial increase in the side facing the lagoon (SE side). The increase observed in Farol Island may be related to the erosion of 
Cemitério Island, that is, the sediment may have been transported from one island to the other. In a sea level scenario the reef islands in Rocas Atoll tends to migrated toward the lagoon (away from the reef edge) with some erosion on the oceanward, and accretion on the lagoonward side. This implies that that reef islands are morphologically resilient landforms that can alter their shape rather than gradually eroding in response to sea level rise (Chapter 0 ).

The results provided unprecedented findings on the functioning of the Rocas Atoll, improving the understanding on the controlling mechanisms of the reef islands morphodynamics and their ability to adapt in response to changes in boundary conditions. The improvement on the knowledge on such processes on Rocas can contribute to the correct management of this environment. Furthermore, our findings provide insights about oceanographic processes on a mesotidal atoll, which are poorly investigated and less understood. Among the main findings we can highlight the reproduction of the lagoon wave climate; the description of a new mechanism of flushing considering relatively large tidal fluctuations; the development of reef islands and their responses to wave energy, in terms of volumetric changes; and the application of a real topo-bathymetry to describe the refraction pattern over an atoll.

\subsection{Contribution to future works}

This thesis focused on the processes induced by wave and tides on Rocas Atoll and its implications on the reef islands morphodynamics. In general terms, the results unprecedented presented in the previous chapters demonstrate the intrinsic link between oceanic waves and water level variations with lagoon processes on Rocas that control its reef islands. Particularly, it was demonstrated that waves drive morphological changes on the reef islands and control the location for sediment accumulation, which can be alter due to sea level rise. However, these processes depend on the available sediment to be reworked on the atoll. Further investigations should be undertaken to estimate the quantity of sediment that is been produced and retained in the atoll. This could be accomplished by using in situ measurements of sediments exchanges between the ocean and the lagoon, combined with measurements of reef carbonate production.

Finally, the findings of this work can also be related to other ongoing research on Rocas Atoll. From the wave propagation model, it was possible to define areas with higher and lower wave energy across the atoll, which may be related to the benthic distributions and variability over the reef rim. In addition, from the digital elevation model it is possible to define the level of reef rim exposure over a tidal cycle. Due to differences in elevation at the windward and leeward margins, it is expected differences in the time of submergence which can affect the growth rate of incrusting organisms. Rocas Atoll is an important nesting site in the South Atlantic Ocean for thousands of seabirds. Results from the topography and mobility of reef islands can be 
used to determine potential areas to inundation and habitat loss for seabird species in response to extreme events or sea level rise. The wave energy that reaches the shoreline and the resulting erosion and accretion patterns can be related to the distribution of green turtle's rookery and their success. 


\section{REFERENCES}

Abelson, A., Denny, M., 1997. Settlement of marine organisms in flow. Annu. Rev. Ecol. Syst. 28, 317-339.

Allard, J., Bertin, X., Chaumillon, E., Pouget, F., 2008. Sand spit rhythmic development: A potential record of wave climate variations? Arçay Spit, western coast of France. Mar. Geol. 253, 107-131. doi:10.1016/j.margeo.2008.05.009

Andréfouët, S., Claereboudt, M., Matsakis, P., Pagès, J., Dufour, P., 2001. Typology of atoll rims in Tuamotu Archipelago (French Polynesia) at landscape scale using SPOT HRV images. Int. J. Remote Sens. 22, 987-1004. doi:10.1080/014311601300074522

Arora, C., Bhaskaran, P.K., 2012. Parameterization of bottom friction under combined wave-tide action in the Hooghly estuary, India. Ocean Eng. 43, 43-55. doi:10.1016/j.oceaneng.2011.12.018

Atkinson, M., Smith, S. V, Stroup, E.D., 1981. Circulation in Enewetak Atoll lagoon. Limnol. Oceanogr. 26, 1074-1083.

Aucan, J., Hoeke, R.K., Merrifield, M., 2012. Wave-driven sea level anomalies at the Midway tide gauge as an index of North Pacific storminess over the past 60 years. Geophys. Res. Lett. 39, 1-6. doi:10.1029/2012GL052993

Baldock, T.E., Golshani, a., Callaghan, D.P., Saunders, M.I., Mumby, P.J., 2014. Impact of sea-level rise and coral mortality on the wave dynamics and wave forces on barrier reefs. Mar. Pollut. Bull. 83, 155-164. doi:10.1016/j.marpolbul.2014.03.058

Barry, S.J., Cowell, P.J., Woodroffe, C.D., 2007. A morphodynamic model of reef-island development on atolls. Sediment. Geol. 197, 47-63. doi:10.1016/j.sedgeo.2006.08.006

Battjes, J.A., Janssen, J.P.F.M., 1978. Energy loss and set-up due to breaking of random waves, in: Proc. 16th Int. Conf. Coastal Eng. pp. 569-587.

BDC, 2015. Banco de Dados Climatológicos do Comando da Aeronáutica - Dados para a estação SNFN entre o período de 2006 a 2014 [WWW Document]. URL http://www.icea.gov.br/climatologia/index.html

Beetham, E.P., Kench, P.S., 2014. Wave energy gradients and shoreline change on Vabbinfaru platform, Maldives. Geomorphology 209, 98-110. doi:10.1016/j.geomorph.2013.11.029

Bellini, C., Marcovaldi, M.A., Sanches, T.M., Grossman, A., Sales, G., 1996. Atol das Rocas Biological Reserve: second largest Chelonia rookery in Brazil. Mar. Turt. 
Newsl. 1-28.

Black, K.P., 1993. The relative importance of local retention and inter-reef dispersal of neutrally buoyant material on coral reefs. Coral Reefs 12, 43-53. doi:10.1007/BF00303783

Booij, N., Ris, R.C., Holthuijsen, L.H., 1999. A third-generation wave model for coastal regions. I- Model description and validation. J. Geophys. Res. 104, 7649-7666. doi:10.1029/98jc02622

Brander, R.W., Kench, P.S., Hart, D., 2004. Spatial and temporal variations in wave characteristics across a reef platform, Warraber Island, Torres Strait, Australia. Mar. Geol. 207, 169-184. doi:10.1016/j.margeo.2004.03.014

Callaghan, D.P., Nielsen, P., Cartwright, N., Gourlay, M.R., Baldock, T.E., 2006. Atoll lagoon flushing forced by waves. Coast. Eng. 53, 691-704. doi:10.1016/j.coastaleng.2006.02.006

Camus, P., Mendez, F.J., Medina, R., 2011. A hybrid efficient method to downscale wave climate to coastal areas. Coast. Eng. 58, 851-862. doi:10.1016/j.coastaleng.2011.05.007

Camus, P., Mendez, F.J., Medina, R., Tomas, A., Izaguirre, C., 2013. High resolution downscaled ocean waves (DOW) reanalysis in coastal areas. Coast. Eng. 72, 5668. doi:10.1016/j.coastaleng.2012.09.002

Chini, N., Stansby, P., Leake, J., Wolf, J., Roberts-Jones, J., Lowe, J., 2010. The impact of sea level rise and climate change on inshore wave climate: A case study for East Anglia (UK). Coast. Eng. 57, 973-984. doi:10.1016/j.coastaleng.2010.05.009

Church, J. a., Clark, P.U., Cazenave, a., Gregory, J.M., Jevrejeva, S., Levermann, a., Merrifield, M. a., Milne, G. a., Nerem, R.., Nunn, P.D., Payne, a. J., Pfeffer, W.T., Stammer, D., Unnikrishnan, a. S., 2013. Sea level change. Clim. Chang. 2013 Phys. Sci. Basis. Contrib. Work. Gr. I to Fifth Assess. Rep. Intergov. Panel Clim. Chang. 1137-1216. doi:10.1017/СВ09781107415315.026

Colbert, A.J., Soden, B.J., 2012. Climatological variations in North Atlantic tropical cyclone tracks. J. Clim. 25, 657-673. doi:10.1175/JCLI-D-11-00034.1

Conceição Junior, J.M. da, 1881. O Baixo das Roccas. Rev. Maritima Brazileira 1, 60-63. Costa Junior, V.J., 1902. Pharologia. Rev. Maritima Brazileira XXII, 723-821.

Costa, M.B.S.F., Araújo, M., Araújo, T.C.M., Siegle, E., 2015. Influence of reef geometry on wave attenuation on a Brazilian coral reef. Geomorphology. doi:http://dx.doi.org/10.1016/j.geomorph.2015.11.001 
Dan, S., Walstra, D.-J.R., Stive, M.J.F., Panin, N., 2011. Processes controlling the development of a river mouth spit. Mar. Geol. 280, 116-129. doi:10.1016/j.margeo.2010.12.005

Dawson, J.L., Smithers, S.G., 2010. Shoreline and beach volume change between 1967 and 2007 at Raine Island, Great Barrier Reef, Australia. Glob. Planet. Change 72, 141-154. doi:10.1016/j.gloplacha.2010.01.026

Dumas, F., Gendre, R. Le, Thomas, Y., Andréfouët, S., 2012. Tidal flushing and wind driven circulation of Ahe atoll lagoon ( Tuamotu Archipelago, French Polynesia ) from in situ observations and numerical modelling. Mar. Pollut. Bull. 65, 425-440. doi:10.1016/j.marpolbul.2012.05.041

Emanuel, K., 2003. Tropical Cylones. Annu. Rev. Earth Planet. Sci. 31, 75-104. doi:10.1146/annurev.earth.31.100901.141259

Ferreira, B.P., Costa, M.B.S.F., Coxey, M.S., Gaspar, a. L.B., Veleda, D., Araujo, M., 2012. The effects of sea surface temperature anomalies on oceanic coral reef systems in the southwestern tropical Atlantic. Coral Reefs 32, 441-454. doi:10.1007/s00338-012-0992-y

Filipot, J.-F., Cheung, K.F., 2012. Spectral wave modeling in fringing reef environments. Coast. Eng. 67, 67-79. doi:10.1016/j.coastaleng.2012.04.005

Findlay, A.G., 1867. A sailing directory for the ethiopic or South Atlantic Ocean, including the coasts of South America and Africa. London : R.H. Laurie.

Fischer, C.F., Avelar, J.C.L., Brito, M., Grosman, A., Carvalho, D.A., Carneiro, C.L., Arruda, M.B., 2007. Plano de Manejo Reserva Biológica do Atol das Rocas. Brasília, Brasil.

Flood, P.G., 1986. Sensitivity of coral cays to climatic variations, southern Great Barrier Reef, Australia. Coral Reefs 5, 13-18. doi:10.1007/BF00302166

Forbes, D.L., James, T.S., Sutherland, M., Nichols, S.E., 2013. Physical basis of coastal adaptation on tropical small islands. Sustain. Sci. 8, 327-344. doi:10.1007/s11625013-0218-4

Ford, M., 2013. Shoreline changes interpreted from multi-temporal aerial photographs and high resolution satellite images: Wotje Atoll, Marshall Islands. Remote Sens. Environ. 135, 130-140. doi:10.1016/j.rse.2013.03.027

Frith, C. a, Mason, L.B., 1986. Modelling wind driven circulation One Tree Reef, Southern Great Barrier Reef. Coral Reefs 4, 201-211.

Gerritsen, F., 1980. Wave attenuation and wave set-up on a coastal reef, in: Proceedings of 17th International Conference on Coastal Engineering. ASCE, 
Sydney, Australia, pp. 441-461.

Gherardi, D.F.M., 1995. A windward coralline algal ridge on Rocas Atoll, Atlantic Ocean. Coral Reefs 14, 34. doi:10.1007/BF00304069

Gherardi, D.F.M., Bosence, D.W.J., 2005. Late Holocene reef growth and relative sealevel changes in Atol das Rocas, equatorial South Atlantic. Coral Reefs 24, 264272. doi:10.1007/s00338-005-0475-5

Gherardi, D.F.M., Bosence, D.W.J., 2001. Composition and community structure of the coralline algal reefs from Atol das Rocas, South Atlantic, Brazil. Coral Reefs 19, 205-219. doi:10.1007/s003380000100

Gherardi, D.F.M., Bosence, D.W.J., 1999. Modeling of the ecological sucession of encrusting organisms in recent coralline-algal frameworks from Atol das Rocas, Brazil. Palaios 14, 145-158.

Godley, B.J., Saunders, K.E., Hartnoll, R.G., Broderick, A.C., 2009. Population Structure of the Land Crab Johngarthia Lagostoma on Ascension Island. J. Crustac. Biol. 29, 57-61. doi:10.1651/08-2992.1

Golshani, A., Baldock, T.E., Mumby, P.J., Callaghan, D.P., Nielsen, P., Phinn, S., 2012. Climate impacts on hydrodynamics and sediment dynamics at reef islands, in: Proc 12th Int Coral Reef Sym, Cairns, Australia. pp. 10-13.

Gourlay, M.R., 1994. Wave transformation on a coral reef. Coast. Eng. 23, 17-42.

Gourlay, M.R., 1988. Coral cays: products of wave action and geological processes in a biogenic environment. Proc. 6th Int. Coral Reef Symp. 2, 6-11.

Hamner, W., Wolanski, E., 1988. Hydrodynamic forcing functions and biological processes on coral reefs: a status review. Proc 6th Int Coral Reef Symp 1, 103113.

Hardy, T. a, Young, I.R., 1996. Field study of wave attenuation on an offshore coral reef. J. Geophys. Res. Ocean. 101, 14311-14326. doi:10.1029/96JC00202

Hardy, T., Young, I.R., Nelson, R.C., Gourlay, M., 1991. Wave Attenuation on an Offshore Coral Reef. Proc. 22nd Coast. Energy Conf. I, 330-344.

Hart, D.E., Kench, P.S., 2006. Carbonate production of an emergent reef platform, Warraber Island, Torres Strait, Australia. Coral Reefs 26, 53-68. doi:10.1007/s00338-006-0168-8

Hazin, M.C., Macedo, R.H., 2006. Sooty tern nesting success as a function of nest location, density and vegetation type in a neotropical atoll. Rev. Bras. Ornitol. 14, 261-268. 
Hearn, C., Atkinson, M., Falter, J., 2001. A physical derivation of nutrient-uptake rates in coral reefs: effects of roughness and waves. Coral Reefs 20, 347-356. doi:10.1007/s00338-001-0185-6

Hench, J.L., Leichter, J.J., Monismith, S.G., 2008. Episodic circulation and exchange in a wave-driven coral reef and lagoon system. Limnol. Oceanogr. 53, 2681-2694. doi:10.4319/lo.2008.53.6.2681

Hoeke, R.K., 2010. An investigation of wave- dominated coral reef hydrodynamics. James Cook University.

Hoeke, R.K., McInnes, K.L., Kruger, J.., McNaught, R.J., Hunter, J.R., Smithers, S.G., 2013a. Widespread inundation of Pacific islands triggered by distant-source windwaves. Glob. Planet. Change 108, 1-11. doi:10.1016/j.gloplacha.2013.06.006

Hoeke, R.K., Storlazzi, C., Ridd, P., 2011. Hydrodynamics of a bathymetrically complex fringing coral reef embayment: Wave climate, in situ observations, and wave prediction. J. Geophys. Res. 116, C04018. doi:10.1029/2010JC006170

Hoeke, R.K., Storlazzi, C.D., Ridd, P. V, 2013b. Drivers of circulation in a fringing coral reef embayment: A wave-flow coupled numerical modeling study of Hanalei Bay, Hawaii. Cont. Shelf Res. 58, 79-95. doi:10.1016/j.csr.2013.03.007

Holthuijsen, L.H., Booij, N., Herbers, T.H.C., 1989. A Prediction Model for Stationary, Short-crested Waves in Shallow Water with Ambient Currents. Coast. Eng. 13, 2354.

Houser, C., D’Ambrosio, T., Bouchard, C., Heyman, W., Darbonne, K., Kuykendall, S., 2014. Erosion and reorientation of the Sapodilla Cays, Mesoamerican Reef Belize from 1960 to 2012. Phys. Geogr. 35, 335-354.

doi:10.1080/02723646.2014.913932

Innocentini, V., Arantes, F.O., Ferreira, R.J., Micheleto, R.G., 2005. a Agitação Marítima No Litoral Nordeste Do Brasil Associada Aos Distúrbios Africanos De Leste. Rev. Bras. Meteorol. 20, 367-374.

IPCC, 2007. Climate Change 2007: impacts, adaptation and vulnerability: contribution of Working Group II to the fourth assessment report of the Intergovernmental Panel. Cambridge University Press, Cambridge, UK.

Jarosz, E., Blain, C. a., Murray, S.P., Inoue, M., 2005. Barotropic tides in the Bab el Mandab Strait-numerical simulations. Cont. Shelf Res. 25, 1225-1247. doi:10.1016/j.csr.2004.12.017

Jokiel, P.L., 1978. Effects of water motion on reef corals. J. Exp. Mar. Bio. Ecol. 35, 8797. doi:10.1016/0022-0981(78)90092-8 
Kayanne, H., Chikamori, M., YAmano, H., YAmaguchi, T., YOkoki, H., SHimazaki, H., 2005. Interdisciplinary Approach for Sustainable Land Management of Atoll Islands. Glob. Environ. Res. 9, 1-7.

Kench, P.S., 1998a. Physical processes in an Indian Ocean atoll. Coral Reefs 17, 155168. doi:10.1007/s003380050110

Kench, P.S., 1998b. A currents of removal approach for interpreting carbonate sedimentary processes. Mar. Geol. 145, 197-223. doi:10.1016/S00253227(97)00101-1

Kench, P.S., Brander, R.W., 2006a. Response of reef island shorelines to seasonal climate oscillations: South Maalhosmadulu atoll, Maldives. J. Geophys. Res. 111, F01001. doi:10.1029/2005JF000323

Kench, P.S., Brander, R.W., 2006b. Wave Processes on Coral Reef Flats : Implications for Reef Geomorphology Using Australian Case Studies. J. Coast. Res.

Kench, P.S., Brander, R.W., Parnell, K.E., McLean, R.F., 2006. Wave energy gradients across a Maldivian atoll: Implications for island geomorphology. Geomorphology 81, 1-17. doi:10.1016/j.geomorph.2006.03.003

Kench, P.S., Brander, R.W.W., Parnell, K.E.E., O'Callaghan, J.M.M., 2009a. Seasonal variations in wave characteristics around a coral reef island, South Maalhosmadulu atoll, Maldives. Mar. Geol. 262, 116-129. doi:10.1016/j.margeo.2009.03.018

Kench, P.S., Chan, J., Owen, S.D., McLean, R.F., 2014. The geomorphology, development and temporal dynamics of Tepuka Island, Funafuti atoll, Tuvalu. Geomorphology 222, 46-58. doi:10.1016/j.geomorph.2014.03.043

Kench, P.S., Cowell, P.J., 2000. Variations in sediment production and implications for atoll island stability under rising sea level, in: 9th International Coral Reef Symposium. pp. 23-27.

Kench, P.S., McLean, R.F., Nichol, S.L., 2005. New model of reef-island evolution: Maldives, Indian Ocean. Geology 33, 145-148. doi:10.1130/G21066.1

Kench, P.S., Parnell, K.E., Brander, R.W., 2009b. Monsoonally influenced circulation around coral reef islands and seasonal dynamics of reef island shorelines. Mar. Geol. 266, 91-108. doi:10.1016/j.margeo.2009.07.013

Kikuchi, R.K.P., 2002. Atol das Rocas, Litoral do Nordeste do Brasil: Único atol do Atlântico Sul Equatorial Ocidental, in: Schobbenhaus, C., Campos, D.A., Queiroz, E.T., Winge, M., Berbert-Born, M.L.C. (Eds.), Sítios Geológicos E Paleontológicos Do Brasil. DNPM/CPRM, Brasília, Brasil, pp. 379-393. 
Kikuchi, R.K.P., Leão, Z.M. a N., 1997. Rocas (Southwestern Equatorial Atlantic, Brazil): an atoll built primarily by coralline algae. Proc. 8th Int. Coral Reef Symp. 1, 731736.

Kraines, B., Yanagi, T., Isobe, M., Guo, X., Komiyama, H., 1999. Rapid water exchange between the lagoon and the open ocean at Majuro Atoll due to wind, waves, and tide. J. Geophys. Res. 104, 15635-15653.

Leatherman, S., Beller-Simms, N., 1997. Sea-level rise and small island states: an overview. J. Coast. Res. 1-16.

Lee, S.P., 1854. Report and charts of the cruise of the U.S. Brig Dolphin: made under direction of the Navy Department. United States. Navy Dept: Printer to the Senate.

Lowe, R.J., 2005. Spectral wave dissipation over a barrier reef. J. Geophys. Res. 110, C04001. doi:10.1029/2004JC002711

Lowe, R.J., Falter, J.L., 2015. Oceanic Forcing of Coral Reefs. Ann. Rev. Mar. Sci. 7, 4366. doi:10.1146/annurev-marine-010814-015834

Lowe, R.J., Falter, J.L., Monismith, S.G., Atkinson, M.J., 2009a. A numerical study of circulation in a coastal reef-lagoon system. J. Geophys. Res. 114, 1-18. doi:10.1029/2008JC005081

Lowe, R.J., Falter, J.L., Monismith, S.G., Atkinson, M.J., 2009b. Wave-Driven Circulation of a Coastal Reef-Lagoon System. J. Phys. Oceanogr. 39, 873-893. doi:10.1175/2008JPO3958.1

Lowe, R.J., Hart, C., Pattiaratchi, C.B., 2010. Morphological constraints to wave-driven circulation in coastal reef-lagoon systems: A numerical study. J. Geophys. Res. 115, C09021. doi:10.1029/2009JC005753

Lugo-Fernández, A., Hernández-Ávila, M.L., Roberts, H.H., 1994. Wave-energy distribution and hurricane effects on Margarita Reef, southwestern Puerto Rico. Coral Reefs 13, 21-32. doi:10.1007/BF00426431

Lugo-Fernández, A., Roberts, H.H., Wiseman, W.J., 1998a. Tide effects on wave attenuation and wave set-up on a Caribbean coral reef. Estuar. Coast. Shelf Sci. 47, 385-393. doi:10.1006/ecss.1998.0365

Lugo-Fernández, A., Roberts, H.H., Wiseman, W.J., 1998b. Tide Effects on Wave Attenuation and Wave Set-up on a Caribbean Coral Reef. Estuar. Coast. Shelf Sci. 47, 385-393.

Madsen, O., Poon, Y., Graber, H., 1988. Spectral Wave Attenuation by Bottom Friction: Theory, in: Coastal Engineering .... pp. 492-504. doi:10.9753/icce.v21. 
Mandlier, P.G., 2013. Field observations of wave refraction and propagation pathways on coral reef platforms. Earth Surf. Process. Landforms 38, 913-925. doi:10.1002/esp.3328

Mandlier, P.G., Kench, P.S., 2012. Analytical modelling of wave refraction and convergence on coral reef platforms: Implications for island formation and stability. Geomorphology 159-160, 84-92. doi:10.1016/j.geomorph.2012.03.007

McGregor, G.R., Nieuwolt, S., 1998. Tropical climatology - An introduction to the climates of the low latitudes, 2nd ed, John Wiley and Sons. New York. doi:978-0471-96611-1

McKoy, H., Kennedy, D.M., Kench, P.S., 2010. Sand cay evolution on reef platforms, Mamanuca Islands, Fiji. Mar. Geol. 269, 61-73. doi:10.1016/j.margeo.2009.12.006

McLean, R.F., Woodroffe, C.D., 1997. Coral atolls, in: Carter, R.W.G., Woodroffe, C.D. (Eds.), Coastal Evolution: Late Quaternary Shoreline Morphodynamics. Cambridge University Press, Cambridge, UK, pp. 267-302.

Meijer, J.J., 2014. Modelling the formation of coral cays on platform reefs. Utrecht University.

Nakamori, T., Suzuki, A., Iryu, Y., 1992. Water circulation and carbon flux on Shiraho coral reef of the Ryukyu Islands, Japan. Cont. Shelf Res. 12, 951-970.

Nelson, R.C., 1996. Hydraulic roughness of coral reef platforms. Appl. Ocean Res. 18, 265-274. doi:10.1016/S0141-1187(97)00006-0

Nelson, R.C., Lesleighter, E.J., 1985. Breaker height attenuation over platform coral reefs, in: Barton, A.C.T. (Ed.), 1985 Australasian Conference of Coastal and Ocean Engineering. Institution of Engineers, Australia, pp. 605-612.

Oliveira, M.A.V. de, 1858. Carta reduzida das Rocas. Paris : Bequet Frères 1.

Parisch, J.E., 1856. Hydrographycal remarks on the Rocas shoal. Naut. Mag. 25, 329331.

Pattiaratchi, C., Olsson, D., Hetzel, Y., Lowe, R., 2009. Wave-driven circulation patterns in the lee of groynes. Cont. Shelf Res. 29, 1961-1974.

doi:10.1016/j.csr.2009.04.011

Pereira, N.S., 2011. Estudos sedimentológicos, morfodinâmicos e mapeamento geomorfológico do complexo recifal do Atol das Rocas, Atlântico Sul.

Pereira, N.S., Manso, V. a V, Macedo, R.J. a, Dias, J.M. a, Silva, A.M.C., 2013. Detrital carbonate sedimentation of the Rocas Atoll, South Atlantic. An. Acad. Bras. Cienc. 85, 52-72. doi:10.1590/S0001-37652013000100005 
Pereira, N.S., Manso, V. V, Silva, A.M.C., Silva, M.B., 2010. Mapeamento

Geomorfológico e Morfodinâmica do Atol das Rocas, Atlântico Sul. Rev. Gestão Costeira Integr. 10, 331-345.

Petit, A.C., 1922. Techonologia Maritima - Notas para um Diccionario Technico. Rev. Maritima Bras. 29, 853-861.

Pianca, C., Mazzini, P.L.F., Siegle, E., 2010. Brazilian offshore wave climate based on NWW3 reanalysis. Brazilian J. Oceanogr. 58, 53-70.

Purdy, E.G., Winterer, E.L., 2001. Origin of atoll lagoons. Bull. Geol. Soc. Am. 113, 837854. doi:10.1130/0016-7606(2001)113<0837:OOAL>2.0.CO;2

Rankey, E.C., 2011. Nature and stability of atoll island shorelines: Gilbert Island chain, Kiribati, equatorial Pacific. Sedimentology 58, 1831-1859. doi:10.1111/j.13653091.2011.01241.x

Richardson, P.L., Walsh, D., 1986. Mapping climatological seasonal variations of surface currents in the tropical Atlantic using ship drifts. J. Geophys. Res. 91, 10537. doi:10.1029/JC091iC09p10537

Richmond, B.M., 1992. Development of Atoll Islets in the Central Pacific, in: Proceedings of the Seventh International Coral Reef Symposium. Guam, pp. 11851194.

Roberts, H.H., 1980. Physical processes and sediment flux through reef-lagoon systems, in: 17th International Coastal Engineers Conference. ASCE, Sydney, Australia, pp. 209-214.

Roberts, H.H., Wilson, P. a., Lugo-Fernández, A., 1992. Biologic and geologic responses to physical processes: examples from modern reef systems of the CaribbeanAtlantic region. Cont. Shelf Res. 12, 809-834. doi:10.1016/0278-4343(92)90046-M

Rodrigues, O.A. de A., 1940. Atol das Rocas. Rev. Marítima Bras. LIX, 1181 - 1228.

Sato, D., Yokoki, H., 2010. Numerical calculation on shoreline conservation in Majuro atoll, the Marshall Islands, in: Proceedings of the Coastal Engineering Conference. Shangai, pp. 1-14.

Schulz-Neto, A., 2004. Aves Marinhas do Atol das Rocas, in: Joaquim Olinto Branco (Ed.), Aves Marinhas E Insulares Brasileiras: Bioecologia E Conservação. UNIVALI, Itajaí, SC, pp. 169-192.

Sheppard, C., Dixon, D.J., Gourlay, M., Sheppard, A., Payet, R., 2005. Coral mortality increases wave energy reaching shores protected by reef flats: Examples from the Seychelles. Estuar. Coast. Shelf Sci. 64, 223-234. doi:10.1016/j.ecss.2005.02.016 
Sheppard, C.R.C., 2002. Island elevations, reef condition and sea level rise in atolls of Chagos, British Indian Ocean Territory, Coral Reef Degradation in the Indian Ocean. Status Report 2002. Kalmar, Sweden.

Shimazaki, H., Yamano, H., Yokoki, H., Yamaguchi, T., Chikamori, M., Tamura, M., Kayanne, H., 2006. Global mapping of factors controlling reef-island formation and maintenance, in: Proceedings of 10th International Coral Reef Symposium. pp. 1577-1584.

Smithers, S.G., Hoeke, R.K., 2014. Geomorphological impacts of high-latitude stormwaves on low-latitude reef islands - Observations of the December 2008 event on Nukutoa, Takuu, Papua New Guinea. Geomorphology 222, 106-121.

Soares, M.D.O., Lemos, V.B., Kenji, R., Kikuchi, P. De, 2009a. Atol das Rocas , Atlântico Sul Equatorial : considerações sobre a classificação do recife biogênico. Rev. Bras. Geociências 39, 238-243.

Soares, M.D.O., Lemos, V.B., Kenji, R., Kikuchi, P. De, 2009b. Sedimentos carbonáticos bioclásticos do Atol das Rocas, Atlântico Sul Equatorial 39, 624-634.

Soares, M.D.O., Meirelles, C.A.D.O., Lemos, V.B., 2011. Reef Bioconstructors of Rocas Atoll, Equatorial South Atlantic doi: 10.5007/2175-7925.2011v24n2p37. Biotemas 24, 37-46. doi:10.5007/2175-7925.2011v24n2p37

Soares, M.D.O., Paiva, C.C. De, Godoy, T. De, Silva, M.D.B., Soraia, C., Castro, S. De, 2010. Environmental management of insular ecosystems : The case of atol das Rocas biological reserve, Equatorial South Atlantic. Management 10, 347-360.

Sørensen, O.R., Kofoed-Hansen, H., Rugbjerg, M., Sørensen, L.S., 2004. A thirdgeneration spectral wave model using an unstructured finite volume technique, in: Proceedings of the 29th Intern. Conf. on Coastal Eng. pp. 894-906.

Springs, C., Springs, C., Springs, C., Springs, C., Climatic, N., Carolina, N., Carolina, N., Springs, C., 2010. The NCEP Climate Forecast System Reanalysis. Am. Meteorol. Soc. 1015-1057. doi:10.1175/2010BAMS3001.1

Stoddart, D.R., 1965. The shape of atolls. Mar. Geol. 3, 369-383.

Stoddart, D.R., Steers, J.A., 1977. The nature and origin of coral reef islands, in: Jones, A.O., Endean, R. (Eds.), Biology and Geology of Coral Reefs. Volume IV. Geology 2. Academic Press, New York, pp. 59-105.

Stone, G.W., Zhangf, X., Sheremetfij, A., 2005. The Role of Barrier Islands, Muddy Shelf and Reefs in Mitigating the Wave Field Along Coastal Louisiana. J. Coast. Res.

Storlazzi, C.D., Elias, E., Field, M.E., Presto, M.K., 2011. Numerical modeling of the impact of sea-level rise on fringing coral reef hydrodynamics and sediment 
transport. Coral Reefs 30, 83-96. doi:10.1007/s00338-011-0723-9

Storlazzi, C.D., Elias, E.P.L., Berkowitz, P., 2015. Many Atolls May be Uninhabitable Within Decades Due to Climate Change. Sci. Rep. 5, 14546. doi:10.1038/srep14546

Tartinville, B., Deleersnijder, E., Rancher, J., 1997. The water residence time in the Mururoa atoll lagoon : sensitivity analysis of a three-dimensional model 193-203.

Tolman, H.L., 2002. User manual and system documentation of WAVEWATCH-III version 2.22 .

Vinhaes, A., 1929. O Atoll das Roccas. Rev. Maritima Bras. XLVIII, 1417-1432.

Vitousek, S., Fletcher, C., Merrifield, M., Pawlak, G., Storlazzi, C., 2007. Model

Scenarios of Shoreline Change at Kaanapali Beach, Maui, Hawaii: Seasonal and Extreme Events, in: Coastal Sediments '07. pp. 1227-1240. doi:doi: 10.1061/40926(239)95

Webb, A.P., Kench, P.S., 2010. The dynamic response of reef islands to sea-level rise: Evidence from multi-decadal analysis of island change in the Central Pacific. Glob. Planet. Change 72, 234-246. doi:10.1016/j.gloplacha.2010.05.003

Wiens, H.J.W., 1962. Atoll Environment and Ecology. Yale University Press, New Haven, Connecticut.

Woelffel, A.B., Alvarez, C.E., 2009. A nova Estação Científica da Reserva Biológica do Atol das Rocas: a adoção de um sistema construtivo tradicional em madeira préfabricada aplicada nas condições ambientais e logísticas de um atol. V Encontro Nac. e III Encontro Latino-Americano sobre Edif. e Comunidades Sustentáveis.

Woodroffe, C.D., 2008. Reef-island topography and the vulnerability of atolls to sealevel rise. Glob. Planet. Change 62, 77-96. doi:10.1016/j.gloplacha.2007.11.001

Woodroffe, C.D., Biribo, N., 2011. Atolls, in: Hopley, D. (Ed.), Encyclopedia of Modern Coral Reefs: Structure, Form and Process. Springer, The Netherlands, pp. 51-71. Woodroffe, C.D., Mclean, R.F., 1994. Reef islands of the Cocos (Keeling) Islands. Atoll Res. Bull.

Woodroffe, C.D., Mclean, R.F., Smithers, S.G., Lawson, E.M., 1999. Atoll reef-island formation and response to sea-level change: West Island, Cocos (Keeling) Islands. Mar. Geol.

Yamano, H., Kayanne, H., Chikamori, M., 2005. An Overview of The Nature and Dynamics of Reef Islands. Glob. Environ. Res. 9, 9-20.

Yamano, H., Miyajima, T., Koike, I., 2000. Importance of foraminifera for the formation 
and maintenance of a coral sand cay: Green Island, Australia. Coral Reefs 19, 5158. doi:10.1007/s003380050226

Yates, M.L., Le Cozannet, G., Garcin, M., Salaï, E., Walker, P., 2013. Multidecadal Atoll Shoreline Change on Manihi and Manuae, French Polynesia. J. Coast. Res. 289, 870-882. doi:10.2112/JCOASTRES-D-12-00129.1

Yokoki, H., Yamano, H., Kayanne, H., Sato, D., Shimazaki, H., 2006. Numerical calculations of longshore sediment transport due to wave transformation in the lagoon of Majuro Atoll , Marshall Islands 1576, 1570-1576.

Young, I.R.R., 1999. Seasonal variability of the global ocean wind and wave climate. Int. J. Climatol. 19, 931-950. doi:10.1002/(SICI)1097-0088(199907)19:9<931::AIDJOC412>3.0.CO;2-O 


\section{APPENDIX}

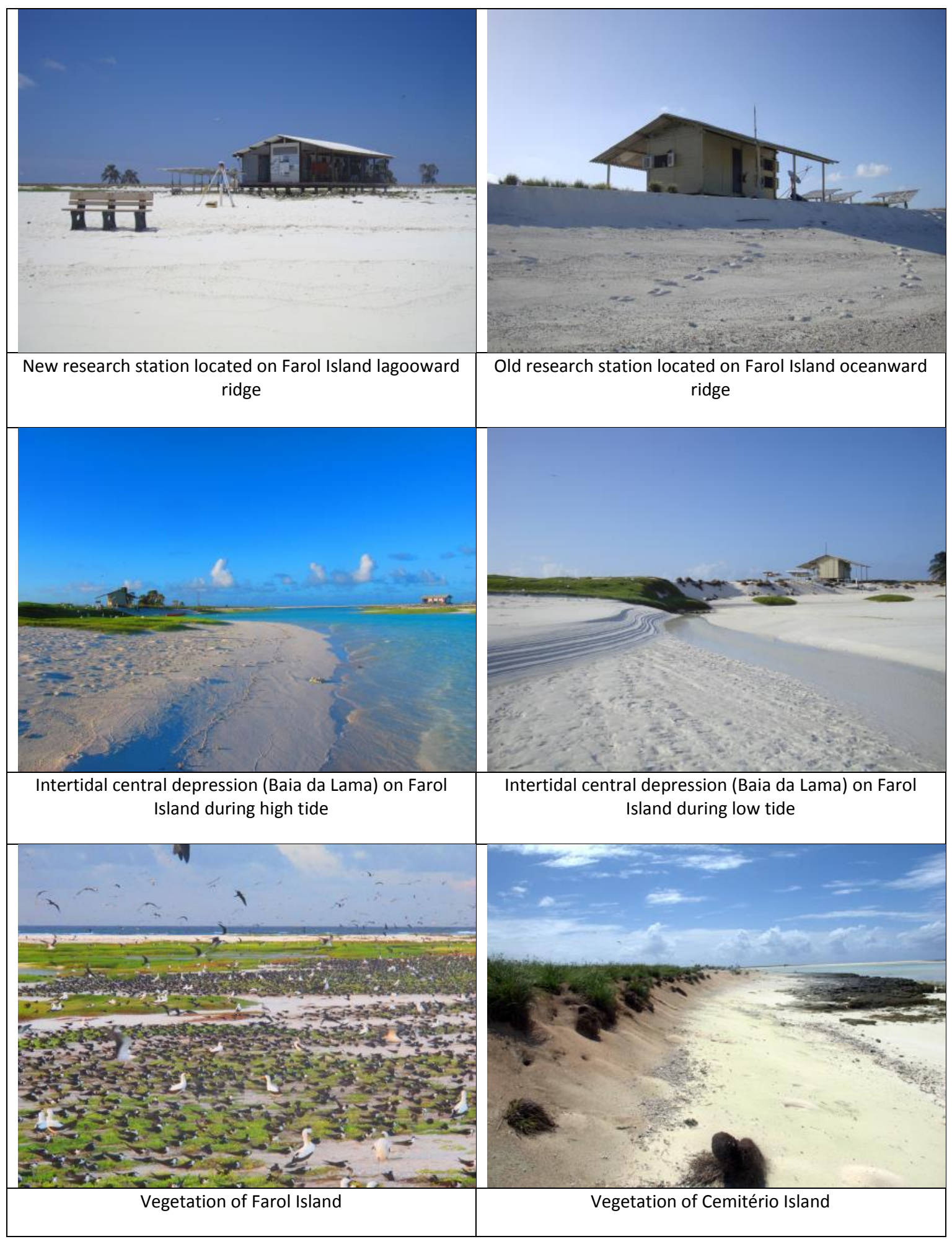




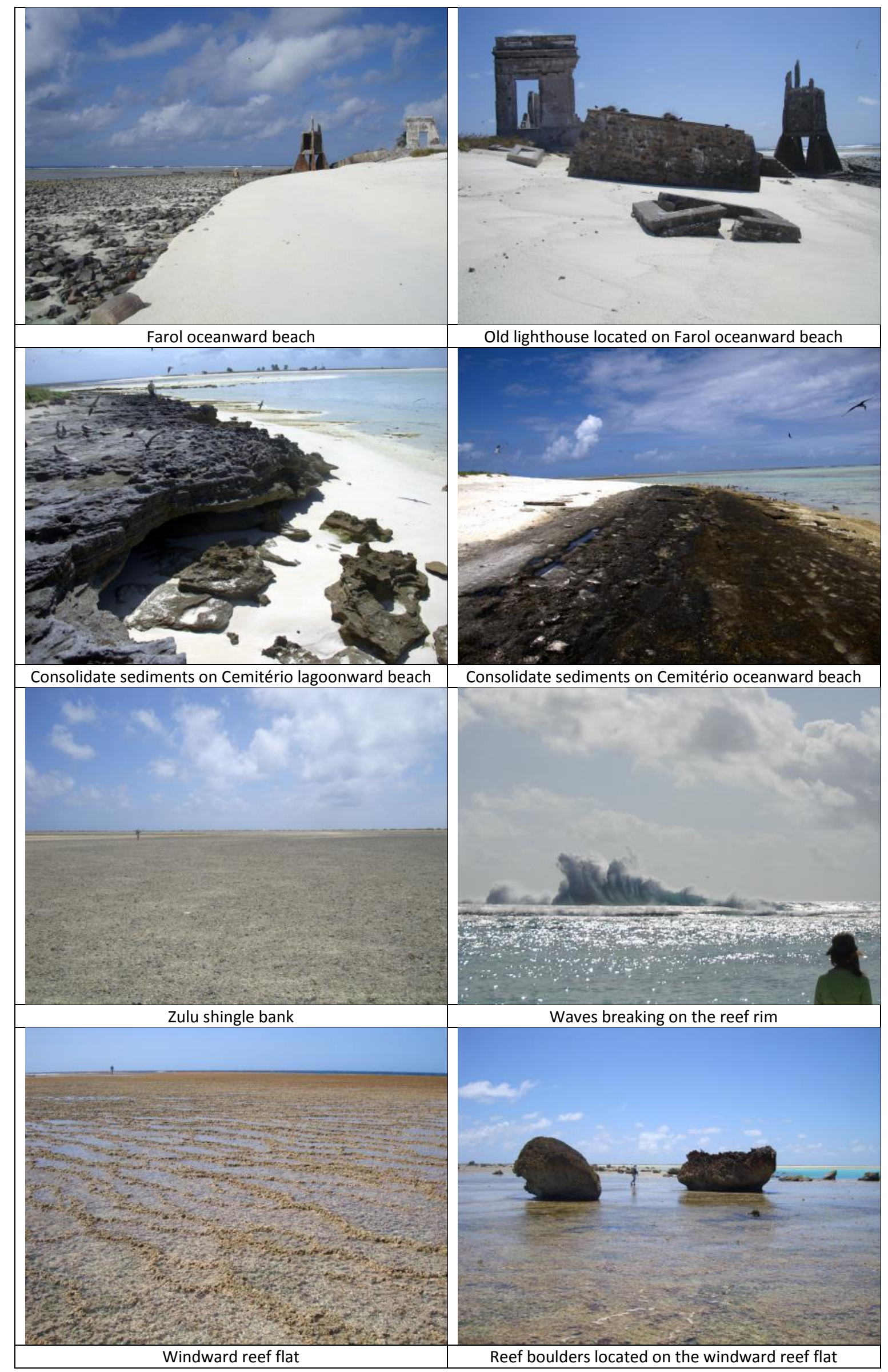




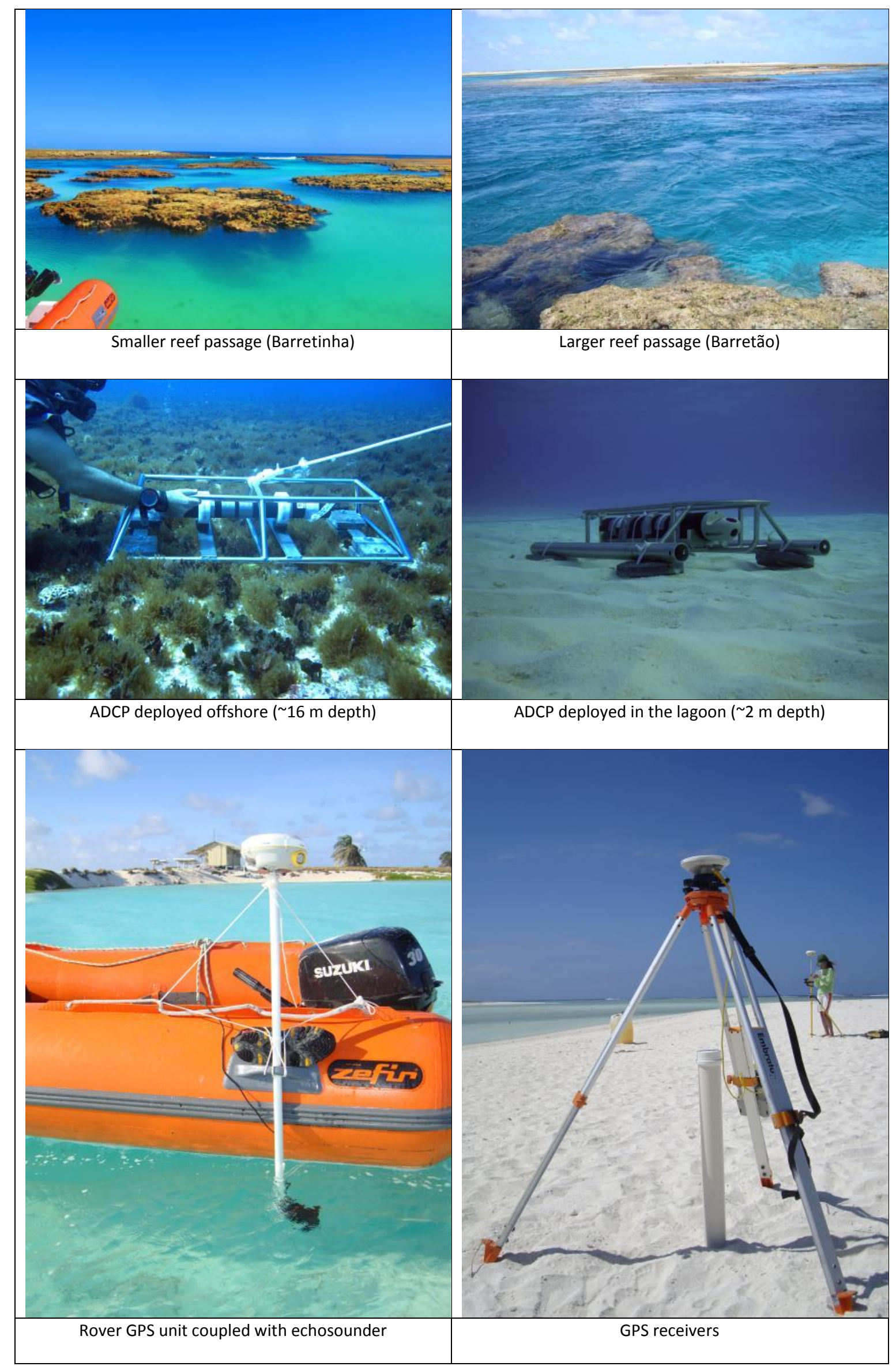

